
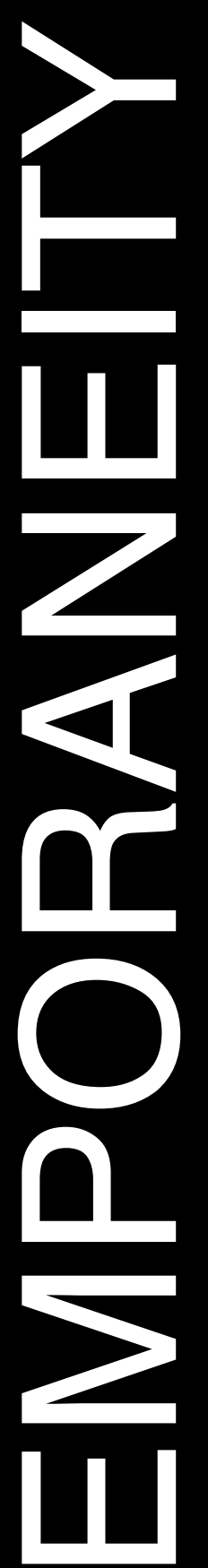

\begin{tabular}{l} 
1 \\
5 \\
\pm \\
\hline \\
0
\end{tabular}
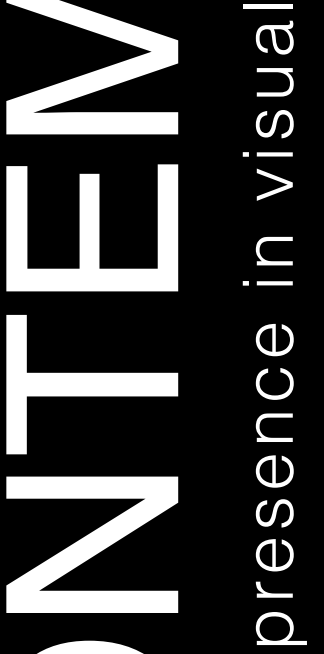

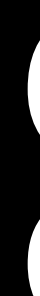

STEPHEN GILCHRIST

ELIZABETH HAWLEY

ANNEMARIE IKER

GARY KAFER

CARLOS KONG

JODI KOVACH

INGRID NORDGAARD

ERIN PETERS

LORETTA RAMIREZ

HENRY F. SKERRITT
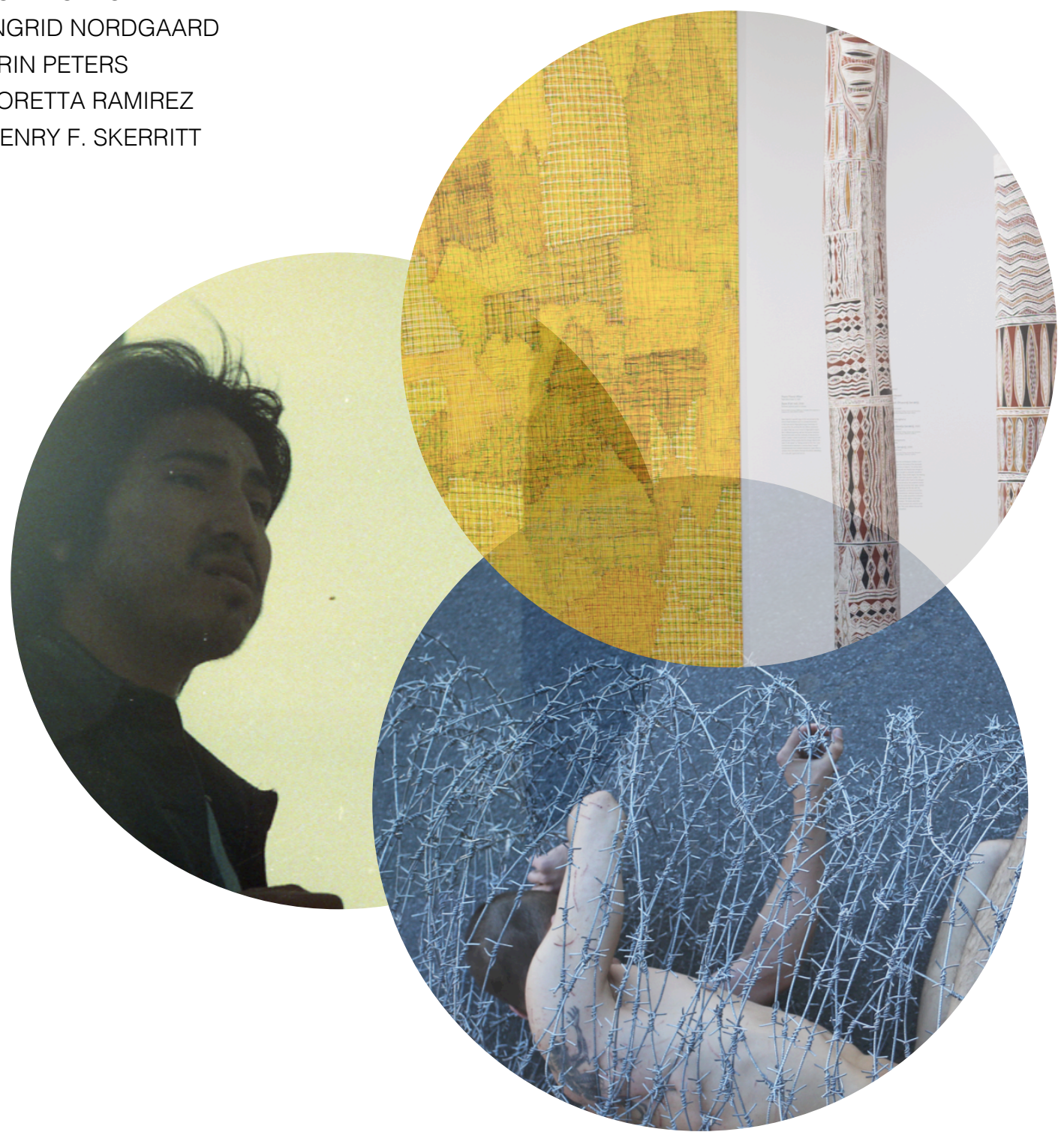

\title{
Agency in Motion
}

Agency \& Reenactment in Visual Culture 


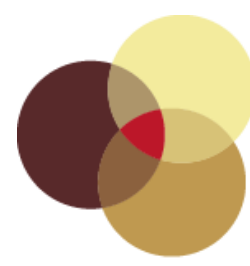

contennporaneine ity

Vol 5, No 1 "Agency in Motion" (2016)| ISSN 2155-1162 (online) | DOI

10.5195/contemp.2016.185

http://contemporaneity.pitt.edu

\section{Agency in Motion}

\section{Editorial Statement}

Nicole F. Scalissi and Annika Johnson

Just what is "Agency"? Is it a scholarly method or orientation? Something we possess or exercise as humans? Or, do objects, networks, environments, and time exert agency as well? Is it always related to power and freedom, or is vulnerability an expression of agency?

Is "agency" determinate, or is it kinetic-as only set into motion or into being when in connection to someone or something else? We encounter this term in a popular context as expression (as artistic agency) or as power (as political agency) and, in academic scholarship, we encounter it often, but with different resonance and meaning across disciplines. While agency perse has not always been the explicit focus of inquiry, recent discourse on violence, politics, sovereignty, and facture indicate a scholarly embrace of a more conscientious, inclusive approach to bodies and things as they move throughout the world and time. It also compels a closer examination of this prevalent, yet elusive, concept by emerging scholars in the field.

In our call for the first thematic edition of Contemporaneity: Historical Presence in Visual Culture, we asked scholars to put the concept of agency into motion. True to our broadest interpretation of "agency," we have invited scholars working through this concept across disciplines to suggest, demonstrate, and provoke in their terms how agency can be brought to bear on visual culture. While we expected a variety of approaches from our contributors, we were thrilled with the many registers across which agency resonated for scholars of photography, performance, and film, including curatorial and pedagogical perspectives. Here, the reader will find a prismatic approach to agency, rather than a universal definition. We do not discredit its previous uses, nor do we police its borders.

Instead-and as we hoped a thematic issue would convene-this edition is the result of conversations that naturally arose among, between, and because of the articles. Ingrid Nordgaard and Elizabeth Hawley consider how artists recover the agency of subjugated or suffering individuals through intertwined photographic and performative practices. Hawley examines the performance piece Take a Picture with a Real Indian in which Luiseño artist James Luna pivots from the historic tensions between the agencies of photographers and Native American subjects, and turns the tourist and museum-goer's cameras on himself. In her examination of pain and performance in post-Soviet Ukraine and contemporary Russia, Nordgaard suggests the photograph is an extension of the subjects' embodied agency, a means of owning, recasting, then sharing their suffering through performance and photographic distribution. 
Photography turned out to be the key "medium" through which contributors mobilized questions of agency in this edition, perhaps indicating a broader trend in agency scholarship. The language around photography-expose, capture, pose, shoot, reproduce, take, sell, document, discover, bare, etc.-proposes opposition, transaction, and the dynamism of relationships that for a moment cluster around the camera and continue to shuffle throughout a photograph's afterlife. Trevor Paglen's photographs of top secret government sites expose the limits of our knowledge and rub up against the aesthetics of abstraction. Yet, as Gary Kafer proposes, it is Paglen's practice of telephotography in remote locations in which the artist exercises political agency. As illuminated by Annemarie Iker, art historian Georgiana Goddard King enlisted photography to envisage Spanish medieva I a rchitecture through the eyes of religious pilgrims and her own-an innovative and experiential approach to architecture history. Jodi Kovach examines Cuban artist Carlos Garaicoa's drawingphotograph diptychs, finding a dialogue in and through multiple frames of temporality in Garaicoa's reimagining of lost architectural sites and his delicate layering of the past and present-opening up new beginnings through temporal disarray.

A special section on curatorial agency addresses how curators might enliven a rt objects and engage viewers with their many pasts and embodied cultural knowledges. They invite a practice that sets objects and the viewing public into motion, challenging traditional notions of curatorship through unexpected collaboration. Erin Peters factors museum visitors into the mix of exhibition-related agents: curators must recognize their capacity to co-create, which requests a fundamental readjustment of how specialist knowledge factors into the display of objects and their reception. In the criticism section, Loretta Ramirez and Carlos Kong parallel this proposal, both pursuing an expanded agency of the viewer in their reviews of two recent exhibitions. Ramirez reviews David Lamelas's The Desert People (Hammer Museum, Los Angeles, 2016) and thinks through the relevance and role of authenticity in the performance of cultural identity. Kong asserts the necessity of subversion and a truly "queer" queerness in his assessment of SuperQueeroes - Our LGBTI* Comic Book Heroes and Heroines (Schwules Museum*, Berlin, 2016).

Curators of Aboriginal Australian art Henry Skerritt and Stephen Gilchrist discuss "Indigenizing" the museum, which for Gilchrist "is about doing; manifesting, instantiating, and running our own race on our own terms." When asked to assess audience reception of the Indigenized museum, Gilchrist hesitates: "It's so hard to be objective." This gives us pause: is "objectivity," with all its associations to Western Ethics, History, and Science, the only means to produce knowledge? Or, might there be an approach to agency that makes room for the subjective, affective, fleshy reality of the scholar? Can there be a way to at once express agency, with its rich texture of subjectivity, and still contribute meaningfully to an understanding of the world and its inhabitants? Or, as Skerritt simply put it: "Well you don't have to be objective."

This serves as a reminder to practitioners of art history of our potential to act in new ways, as well as the power invested in our scholarly actions. An activation of professional agency is the power to challenge silos and re-district disciplines, to invest or restore real agency to underrepresented communities or regions, makers and viewers, and objects themselves. We encourage our readers to formulate their own questions and share them with us through submissions, letters to the editors, and social media.

Agency in Motion was a collaborative effort. Our authors, editors, and interview subjects generated and shaped exceptional content. Artists, archivists, peer reviewers, and galleries engaged with contributors at all levels to bring their material to light. The hard work and support of our coeditors in chief Meredith North and Ben Ogrodnik, our editorial board, advisory board, and intern Victoria Sterling; the generous contributions of donors in our 2016 EngagePitt fundraising campaign; and the intellectual community housed in the 
Department of History of Art and Architecture at the University of Pittsburgh have made this vision possible, and secure its future.

We share with you below our first vision statement, which establishes Contempora neity as a platform for scholars to develop and voice their ideas through a rigorous and constructive editorial process. As we continue to diversify our content and perspectives across traditional divides of discipline, historical eras, and media, we seek to produce points of connection among different fields in a shared effort to better understand the world through its visual registrations.

Nicole F. Scalissi, Coeditor in Chief

PhD Candidate, History of Art and Architecture, University of Pittsburgh

Arts \& Sciences Fellow, University of Pittsburgh

Annika Johnson, Coeditor in Chief

PhD Candidate, History of Art and Architecture, University of Pittsburgh

Predoctoral Fellow, Smithsonian American Art Museum

\section{Vision Statement}

Contemporaneity is an open access journal that publishes scholarly and artistic explorations of how the complexities of being in the world have found visual form throughout time. Editorial leadership is based in the department of the History of Art \& Architecture at the University of Pittsburgh where the journal is enriched by its innovative constellations proqram. We publish question-driven research that resonates across disciplines, interrogating diverse visual material from across time using multiple methods. Our editorial board seeks to:

- Adhere to high publishing standards that preserve the integrity of scholarship

- Bring junior and senior scholars and editors together through a constructive, double-blind peer-review process

- Generate content of lasting intellectual interest to emerging and tenured scholars

- Provide a forum for junior and senior scholars to develop under-researched topics and experimental methodological approaches

- Make scholarly writing free and accessible online

- Lead critical discussions around current publications and developments in curato rial and artistic practice in flexible formats

- $\quad$ Link art historical practice to a global discussion of visual cultures across disciplinary and methodological boundaries

- Encourage non-traditional formats 
$(\mathrm{cc})$ BY

New articles in this journal are licensed under a Creative Commons Attribution 4.0 United States License.

\section{ULLS D-Serk}

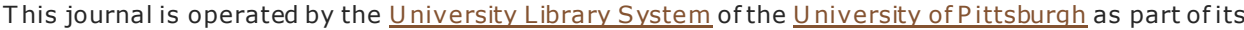
D-Scribe Digital Publishing Program, and is co-sponsored by the University of Pittsburgh Press. 


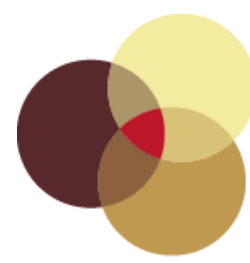

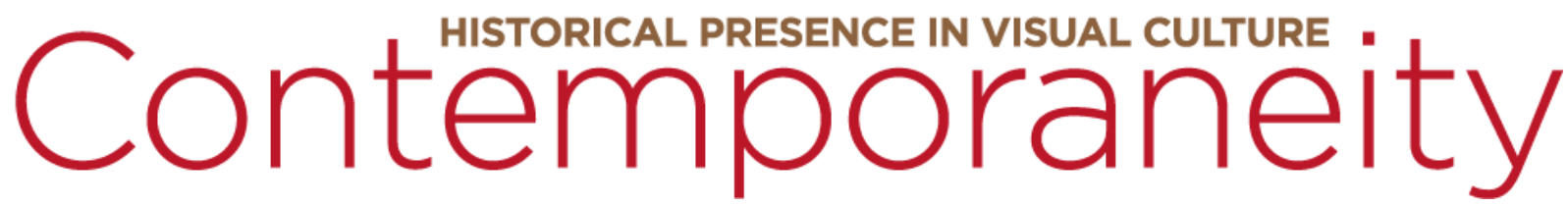

Vol 5, No 1 "Agency in Motion" (2016) | ISSN 2155-1162 (online) | DOI

$10.5195 /$ contemp.2016.170

http://contemporaneity.pitt.edu

\title{
James Luna and the Paradoxically Present Vanishing Indian
}

Elizabeth S. Hawley

\begin{abstract}
James Luna's performances interrogate how representations of Native Americans have been made to fit western assumptions about the "real Indian." Using his recognizably Native body as a marker of both presence and endangered existence, Luna links Peggy Phelan's conception of performance as the presence of loss with the centuries-old stereotype of Native Americans as the "vanishing race"-a stereotype that continues to exert influence. In Take a Picture with a Real Indian (performed in 1992, 2001, and 2010), he invites viewers to have their photograph taken with him wearing one of three options: war dance regalia, a loincloth, or khakis and a polo shirt. Few people choose the third option. The performance foregrounds what has become a tradition of Native Americans performing/posing their native -ness as Otherness for the camera, strategically employing imagery that plays to nostalgic Western views of Native peoples as perpetually vanishing. I argue that Luna's performances comment not only upon western preconceptions of Native Americans, but also upon the ways that Native Americans have historically reasserted their agency by manipulating such expectations, staging themselves to fit the stereotype.
\end{abstract}

\section{About the Author}

Elizabeth S. Hawley is a PhD Candidate in Art History at the CUNY Graduate Center. Her dissertation analyzes the art production in Santa Fe, New Mexico in the early twentieth century, putting the works of American Modernists who visited the area into dialogue with the works of Native artists from the surrounding Pueblos. Hawley earned her MA from the Courtauld Institute of Art, and her BA from Harvard University. She recently completed a Museum Research Consortium Fellowship at the Museum of Modern Art, New York, where she undertook research on Frank Lloyd Wright's use of Native and Meso-American forms in his architecture and decorative designs. She is currently teaching art history courses at York College and St. Francis College. 


\section{James Luna and the Paradoxically Present Vanishing Indian}

\section{Take a Picture}

On October 12, 1911-Columbus Day-Ho-Chunk artist Angel DeCora took to the podium at a Society of American Indians conference to give a talk on Native American art. She argued for the development of the "decorative instinct of the Indian to modern methods" in response to the rapid and continual renegotiation of her people's position in society and history. ${ }^{1}$ DeCora concluded her rousing speech with the assertion that "the Indian in his native dress is a thing of the past, but his art that is inborn shall endure."2

Nearly a century later contemporary Luiseño performance artist James Luna used the occasion of Columbus Day to stage a work that indeed proved DeCora's prediction of the endurance of what she termed "Indian art" prescient, albeit in a postmodern, parody-laced manner that continued to incorporate the native dress DeCora already assumed anachronistic. In the performance, provocatively titled Take a Picture with a Real Indian (2010), Luna placed three life-size, black and white cardboard cutouts of himself at the base of the Columbus Memorial, a park-like traffic circle adjacent to the capital grounds in Washington, D.C. that houses a huge statue of the man who claimed to have discovered America (fig. 1). The memorial immediately calls forth stereotypes of the Indian against which Luna positions his own work: on the west side of the sculpture, an unnamed American Indian kneels at Columbus's feet, and an inscription claiming that Columbus "gave to mankind a New World" leaves unacknowledged the fact that American Indians had inhabited this land for centuries, and further denies them a place in the Euro-American conceptualization of "mankind."

Against this backdrop Luna positioned three cutouts of himself clad in different clothing: in one he wears a buckskin breechcloth and moccasins; in the next, he sports regalia including feathered headwear and a beaded breastplate; and in the third, he appears dressed in khakis and a polo shirt. Luna then stepped onto the makeshift stage that had been placed between the cutouts three times, each time wearing a version of the costumes depicted in the cutouts, and each time reciting, "Take a picture with a real Indian. Take a picture on this beautiful sunny day. Take a picture with a real Indian on one of the saddest days of our history . . . America needs to face up to reality. America needs to put down the romanticism. " ${ }^{3}$ He explained to audience members that they could only have their picture taken with him once by one of the professional photographers he hired for the occasion. The photographers would produce two Polaroids, one to be left with the artist, and one for the audience member to keep as a memento. Viewers then approached the stage to have their

\footnotetext{
${ }^{1}$ A ngel DeCora, "Native Indian A rt," in Report of the Executive on the Proceedings of the First Annual Conference of the Society of American Indians Held at the University of Ohio, Columbus, O hio (O ctober 12 -17,1911), 1:84. For further information on DeC ora see Elizabeth Hutchinson, The Indian Craze: Primitivism, Modernis m, and Transculturation in American Art, 1890-1915 (Durham: Duke University Press, 2009).

2 DeCora, "N ative Indian Art," 87.

${ }^{3}$ James Luna, Take a Picture with a Real Indian performed in 2010, Was hington D.C. National Museum of the A meric an Indian performance recording, accessed from http://www.facebook.com/video/video.php?v=10100243886416480.
} 
photo taken with whichever clothing-designated iteration of the artist that they felt best represented a "real Indian." ${ }^{4}$ Perhaps inevitably, most participants chose to be photographed with Luna while he was wearing his regalia.

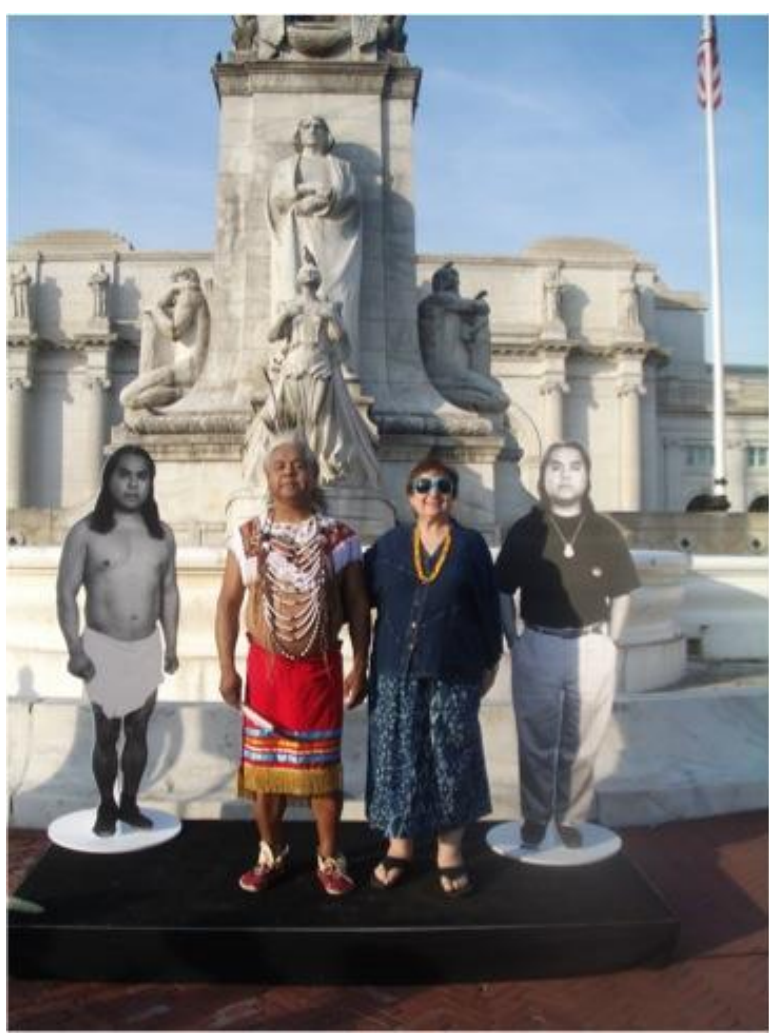

\section{Figure 1}

James Luna, Take a Picture with a Real Indian, 2010 . Live performanceinstallation with photographs, Washington, D.C.P hotographer unknown. I mage courtesy of James Luna.

Take a Picture is particularly pointed in its interrogation of the pose and the photograph, and how both Native and non-Native peoples are implicated in and affected by the resulting stereotypes: Native peoples are expected to adhere to the stereotypic construction of Indian identity, but in performing this role, they reify the stereotype. At the same time, non-Native peoples perpetuate the problematic cycle by only characterizing as "Indian" those Native peoples that adhere to the stereotype that non-Native peoples have constructed and come to expect. This article addresses the ways in which Luna's performance engages with the history of such constructions, their problematic persistence in the present, and the evolution of theoretical discourse around these issues.

Luna often restages his works, and the 2010 performance of Take a Picture was itse If a reenactment. The cardboard cutouts of Luna depict him as a younger man and can be seen in a photograph of his original performance of the piece at the Whitney Museum of Art in 1991 (fig. 2). As Amelia Jones observes, "re-enactments remind us all that present

\footnotetext{
${ }^{4}$ When I use the term "real Indian" in the following article, I a m alluding to Luna's conception of an Indian identity that fits -or is constructed to fit-non-Native expectations.
} 
experience, including . . . the apprehension of things called 'art' or acts called 'performance,' is only ever available through subjective perception." ${ }^{5}$ Luna's performance at the base of the Columbus monument doubled such subjectivity: he staged a long-standing stereotype of the Native American and did so within the context of a performance that has had previous iterations. Nearly twenty years after the first performance, he tested whether the outcome of the 2010 version would be less starkly stereotypical in terms of audience subjectivity. He perhaps expected participants to be less inclined to deem his regalia-clad self the real Indian, since such categorization is a fallacy, and none of the three characters performed by Luna can be declared more "Indian" than the others. The performance, however, played out much as it had two decades before, which he had described thus:

It . . . was leading-There was an Indian in a breechcloth with everybody going 'Oh wow, there's an Indian.' Then I came out in my street clothes and they said, 'Oh, there's a guy.' But when I came out in my regalia, I knew that it would get that response from the audience. Everybody went for it. There was a big ooh and aah when I stepped up on that pedestal with my war dance outfit. They forgot about all the rest and really lined up to have their picture taken. This is the memento that they really wanted. Even people that were art savvy fell for it. 6

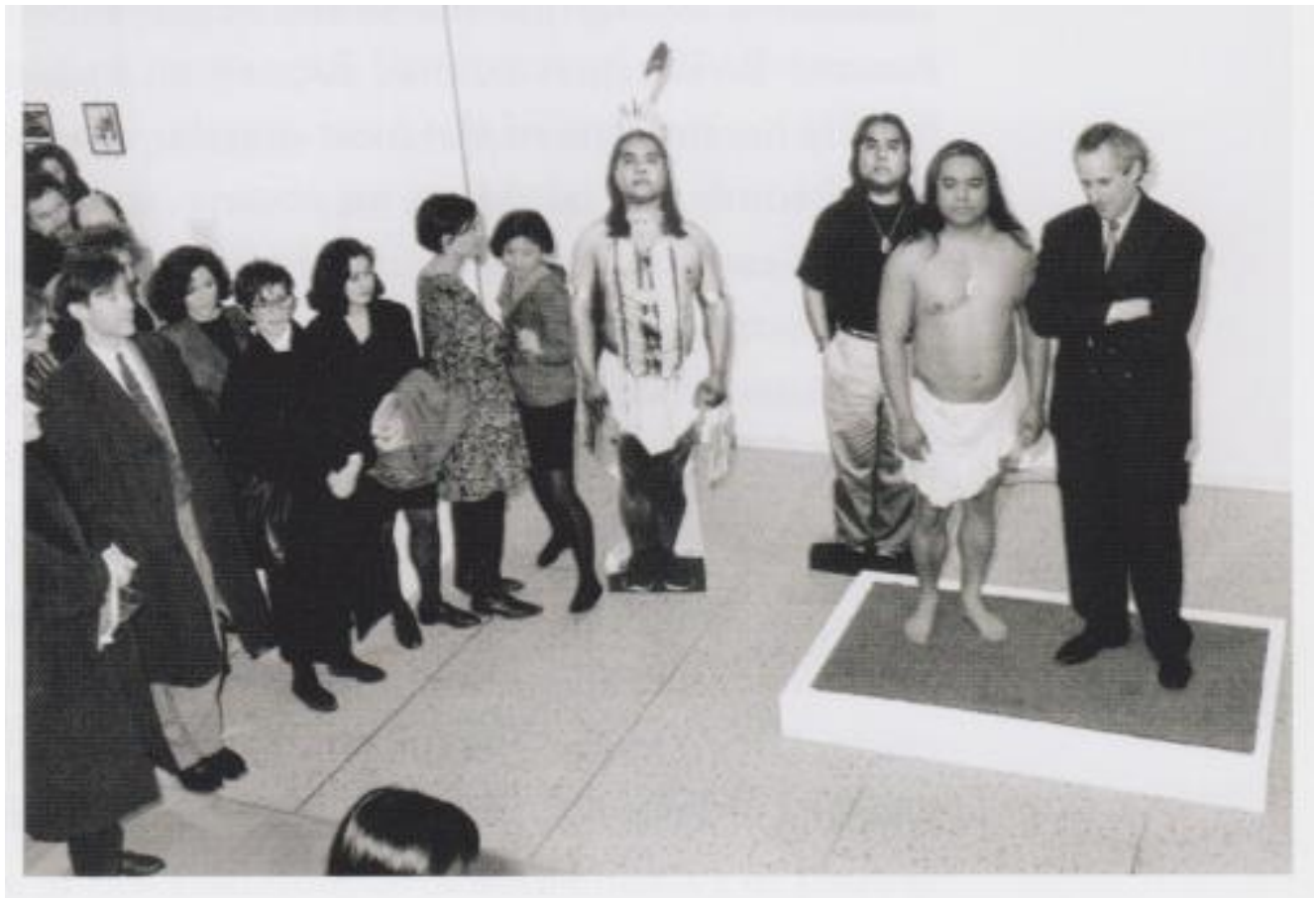

Figure 2

James Luna, Take a Picture with a Real Indian, 1991. Live performance-installation with photographs, Whitney Mus eum of A merican A rt. P hotographer unknown. I mage courtesy of James Luna.

\footnotetext{
${ }^{5}$ A melia Jones, "'The A rtist is Present': A rtistic Re-enactments and the Impossibility of Presence," TDR: The Drama Review 55, no. 1 (Spring 2011): 42.

${ }^{6}$ Kenneth R. Fletcher, "James Luna," Smithsonian Magazine (A pril 2008 ), http://www.s mithsonianmag.com/arts-culture/james-luna-30545878/.
} 
Of course, having his audience members "fall for" this outcome was crucial to the message of the work; in order to point to the persistence of Native stereotypes, Luna had to create a situation in which they are unlikely to be overcome. His use of the term "leading" is telling, for the manner in which the work was presented ensured a certain scripted outcome, and failure to achieve this outcome would have detracted from the artist's intended message by rendering it an overstatement. The cutouts informed viewers which costumes Lu na would don during the performance and by saving the best for last, so to speak, he set up a situation in which the majority of photographs would be taken of his last appearance, both because this costume is the most visually striking and because it was the last chance to take a photograph-the grand finale of the performance. Agency, here, was with the artist; Luna was in control, manipulating audience members to achieve a more powerful statement with the work. But in doing so, he re-inscribed the stereotypes of Indian identity against which the work was ostensibly aimed. Then again, while the "art savvy" people may have been duped, they also may have been consciously participating in Luna's performance of paro dic, scripted stereotypes. Perhaps aware of Luna's intended message, it is possible that these viewers played the role of uninformed audience members ignorant of contemporary Native American experiences and concerns, as expected-needed even-by the artist.

Luna mentions these savvy spectators because, as with most of his works, he first performed Take a Picture in a museum. Staging the work outside of the museum context in 2010 marked an intriguing departure from his usual practice and caused a change in the scripted quality of the piece. It gave viewers both more and less command over their own actions: more in that Luna could not control unauthorized photographs of a performance staged in a public space, and less in that some viewers stumbled upon the work, thus receiving only a fragmentary explanation of it and what their actions might signify. ${ }^{7}$ And while the towering Columbus monument provided a politically suggestive backdrop to the performance that took place on a controversial national holiday, I argue that as a public space it also foregrounded the significance of photography in the work. ${ }^{8}$

Luna's earlier performances of the piece include the aforementioned 1991 Whitney Museum location, as well as a 2001 staging at the Herbert F. Johnson Museum of Art at Cornell University. ${ }^{9}$ In these contexts, the "take a picture, leave a picture" component of the performance could be better enforced, since museum photography policies and the guards who enforce them would have discouraged participants from taking their own photographs. Indeed, the institutional setting protected Luna and his performance from concerns varying from copyright infringement to potential heckling. In the open space of the monument, however, Luna's posed body became subject to unauthorized photographs taken by any one in the area. Holly Stewart, Social Media Coordinator of the National Museum of the American Indian, noted that "the setting was inspired," and described "a second ring of audience-

\footnotetext{
7 The performance was sponsored by the Smithsonian's N ational Museum of the A merican Indian in as sociation with "V antage Point: The Contemporary Native A merican A rt Collection," an exhibition that highlighted the work of twenty-five contemporary Native A merican artists working in all media, including performance.

8 That morning, the U.S. Marines had held their a nnual ceremony in honor of Columbus Day and had placed wreaths of flowers on the other side of the statue. This evidence of their nationalistic reverence stood in stark contrast to Luna's subsequent performance on the opposite side of both the statue and the ideology to which it bears witness.

${ }^{9}$ A curtailed version of the work was also staged in Times Square, New York City in 1994 as part of The $42^{\text {nd }}$ Street Art Project. In this piece, the three cutouts were placed in a small storefront window and an audio element instructed passersby as to the intent of the work.
} 
participants snapping photographs from taxis and tour buses." ${ }^{10}$ The photographs resulting from this outer edge of action were a consequence of the public setting as well as contemporary image culture itself, in which nearly anyone with a phone has the capability of quickly documenting moments, memorable or not, from their day-to-day experiences. Such was not the case at the original staging of Take a Picture, both because the museum context set a tone of respectful audience obedience in terms of documentation, and simply because cameras were less common and more obtrusive. Attempting to regulate images of their work has become increasingly difficult for performance artists, particularly for pieces performed in public. The 2010 version of Take a Picture created a mise-en-abyme of photos-carefully composed by Luna's professional photographers, amusedly taken by friends of the participants who ventured onstage, and hastily snapped by confused but intrigued passengers in cars swinging around the traffic circle. Luna's performance here thus alluded to both our contemporary conceptualization of photography and documentation, as well as to Luna's loss of control concerning the image of himself and his art.

\section{Reading Photographs of Native Americans}

The latter aspect speaks to a long history of non-Native photographers turning Native Americans into the unknowing, hesitant, or unwilling subjects of their images. Scholars in the 1980s and 1990s frequently referenced these histories in their analyses of photographs depicting Native peoples, often comparing the photographer's camera to the colonizer's gun: Vine Deloria, Jr. calls early twentieth-century photography "a weapon in the final skirmishes of cultural warfare in which the natives of North America could be properly and finally embedded in their places in the cultural evolutionary incline. ${ }^{11}$ Comanche curator Paul Chaat Smith takes this analogy a step further, arguing that just as the Walker Colt revolver was "a machine designed for one purpose: to kill Comanches ... There should have been a special camera invented to shoot Indians as well, given the tremendous influence photography has had on us." 12 Smith observes, "those [Indian coffee-table] books and the photographers behind them are like big game hunters on safari and their big game is the real Indian."13 The hunters ignore the "fourteen year old boy in baggy pants" and the "fat guy with the Marine haircut," just as Take a Picture participants seldom desired a picture with Luna in his khakis. ${ }^{14}$ The so-called real Indian sought by the camera-wielding hunters described by Smith was, and continues to be, the regalia-clad version of the real Indian in Luna's performance-the spectacle of Otherness.

Many Native Americans balked at the intrusive cameras, for a variety of reasons, but their desires to remain un-photographed were ignored. Some feared the implications of having their image replicated on paper; Lucy Lippard observes that the "transfer of a black and-white likeness to paper meant to some that a part of their lives had been taken away, to

\footnotetext{
${ }^{10}$ Holly Stewart, "James Luna: Take a Picture with a Real Indian," The National Museum of the American Indian Blog, O ctober 12, 2010 , http://blog.nmai.si.edu/main/2010/10/james-luna-take-a-picture-with-areal-indian.html.

${ }^{11}$ V ine Deloria, Jr., I ntroduction to Christopher M. Lyman, The Vanishing Race and Other I/lusions: Photographs of Indians by Edward S. Curtis (New York: Pantheon Books, 1982), 11.

12 Paul Chat Smith, "Ghost in the Machine" in Strong Hearts: Native American Visions and Voices, ed. Peggy Rolf (New York: A perture, 1995), $6-7$.

13 Ibid., 7 .

14 Ibid.
} 
others that their vital power had been diminished."15 However, this fear should not be overstated; the stereotype that Native Americans feared cameras would "steal their souls" has become an enduring and inaccurate perception. Other Native Americans objected to this exploitative photography not out of fear, but in protest against its intrusiveness. Jane Alison analyzes the literalized rhetoric of non-Natives taking photographs of Natives, emphasizing that these images are taken, not requested. ${ }^{16}$ James $C$. Faris examines unequal photographic encounters at length, pointing to images like Navajo Children (ca. 1925), which shows a missionary student and two young boys tightly grouped together as though to avoid the photographers that close in on them (fig. 3). The younger boy hides in the skirts of the student, as she and the older boy look away from both the photographer in the image, as well as the unknown photographer from whose view we access the scene. Just as the student and children avoid the immediate threat of the camera-wielding photographers, so too do they avoid the gaze of contemporary viewers, thus implicating the viewer in the invasive scene. Their evasion is echoed in Three Navajo girls wearing blankets (ca. 1936-1941), which shows three young Native American women, two with their heads turned and a third who casts her eyes downwards, refusing the gaze of the camera (fig. 4). Faris notes that this refusal is seen over and over again in photographic archives, and that "such photographs are often labeled 'shy women'-that is, in terms that do not condemn the photographer." 17

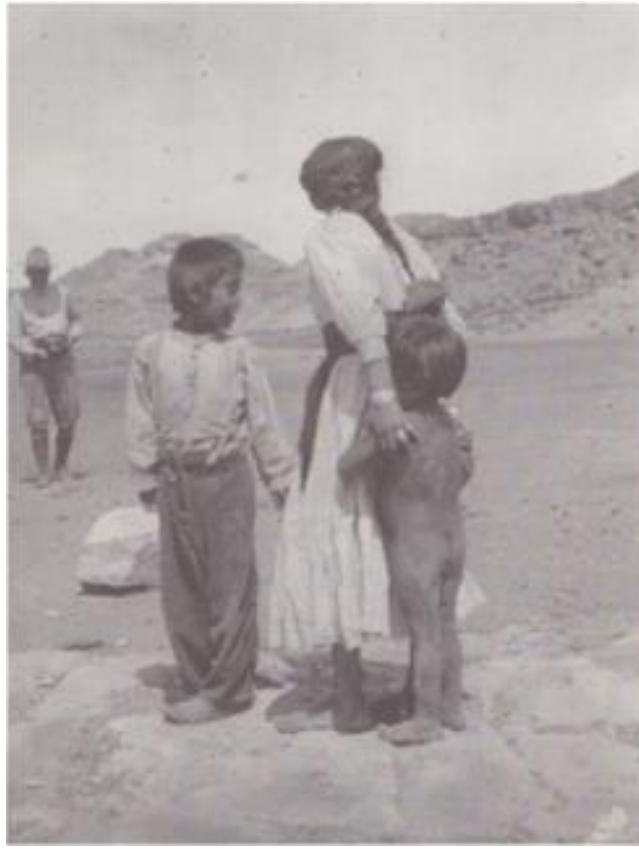

\section{Figure 3}

Photographer unknown, Navajo Children, ca. 1925 . I mage courtesy Palace of the Governors. Photo A rchives (NMHM/DCA), \#53801.

\footnotetext{
${ }^{15}$ Lucy R. Lippard, Introduction to Partial Recall: Photographs of Native North Americans (New York: The New Press, 1992), 30 -31.

${ }^{16}$ Jane A lison, Introduction to Native Nations: Journeys in American Photography (London: Barbican A rt Gallery, 1998), 14 .

17 James C. Faris, Navajo and Photography: A Critical History of the Representation of an American People (A lbuquerque: University of N ew Mexico Press, 1996), 47. Lucy Lippard also comments on this visual phenomenon, noting that, "[i]n the archives, there are many photographs of Native people hiding their faces or otherwise trying to avoid the camera... Soon it was recognized as the ultimate invasion of social religious, and individual privacy." Lippard, Partial Recall, 29.
} 


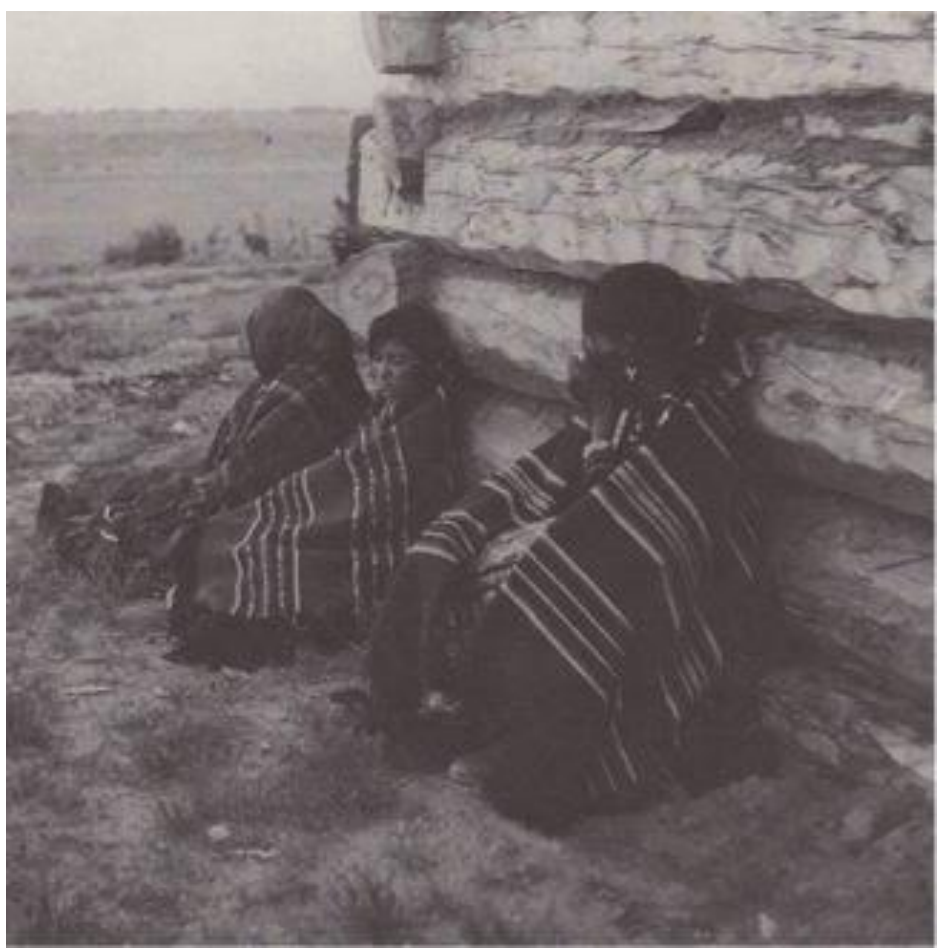

\section{Figure 4}

Helen M. Post, Three Navajo girls wearing blankets, ca. 1936-1941). Gelatin silver print, $8 \times 715 / 16$ in. Image courtes $y$ of the A mon Carter Museum, Fort Worth, TX, P1985.50.837.

Of course, not all Native Americans objected to cameras, and scholars should refrain from assuming that any image of a Native person is a portrayal of victimhood. If some Native Americans shunned cameras and photography, others were curious and used them to their advantage. Scholars in the last fifteen years have moved beyond analyzing the presumed objectification of Native subjects to instead examine Native cognizance, collaboration, and participation in the photographic process. Frank H. Goodyear argues that Lakota leader Red Cloud exploited photography and the Western fascination with his image to emphasize his continued existence and relevance in contemporary society. ${ }^{18}$ In his study of $\mathrm{H}$. H. Bennett's photographs of members of the Ho-Chunk nation, Steven D. Hoelscher argues that while photography has "served as a technology of domination to subdue indigenous peoples . . . it has also worked to provide those very peoples a medium for their cultural survival, endurance, and renewal-for their survivance. ${ }^{\prime 19}$

This concept of survivance, along with the related theories of contact zones and visual sovereignty has shifted the framework of analysis for such imagery. Gerald Vizenor defines survivance as "an active sense of presence, the continuance of native stories, not a mere reaction, or a survivable name," arguing that "Native survivance stories are renunciations of

\footnotetext{
${ }^{18}$ Frank H. Goodyear, Red Cloud: Photographs of a Lakota Chief (Lincoln: University of Nebraska Press, $2003)$.

${ }^{19}$ Steven D. Hoelscher, Picturing Indians: Photographic Encounters and Tourist Fantasies in H. H. Bennett's Wiscons in Dells (Madison: The University of Wisconsin P ress, 2008), 10.
} 
dominance, tragedy, and victimry."20 Native peoples do not just survive, they actively recalibrate cultural mores in ways that honor the past, accept the present, and anticipate the future. This takes place within social spaces that Mary Louise Pratt has termed contact zones. She acknowledges the imbalanced power relations, coercion, and conflict associated with such zones, but also notes, "while a subjugated people cannot readily control what emanates from the dominant culture, they do determine to varying extents what they use for their own, and what they use it for."21 While Luna cannot change the invasive way that American Indians have been photographed, he can take this technology and use it for his own purposes-namely, to reference these photographic histories, the stereotypes that they reveal, and to question the way stereotypic attitudes toward and expectation of Native peoples circulate in the present.

Michelle $\mathrm{H}$. Raheja has coined the term visual sovereignty to describe the tactics Native Americans have used "to confront the spectator with the often absurd assumptions that circulate around visual representations of Native Americans, while also flagging their involvement and, to some degree, complicity in these often disempowering structures of . . . dominance and stereotype." 22 In Raheja's study of representations of Native Americans in cinema, she considers both Native participants in early films produced by non-Natives, as well as contemporary Native filmmakers, noting that stereotypic images of Native Americans have become a part of Native history, especially since Native Americans at times participated in the creation of such stereotypes. ${ }^{23}$ Rather than reject such imagery, contemporary filmmakers and performance artists grapple with the implications of collusion.

Of course, there are shades of gray within the spectrum of sovereignty. Lippard references the case of Lillie Benally, a Navajo woman who allowed Laura Gilpin to photograph her in 1932, but did not consent to the publication of the image. Upon hearing that the Amon Carter Museum in Fort Worth, TX was using the photograph in museum publicity materials in 1984, she sued. ${ }^{24}$ Benally's case points to the complex web of legal and cultural issues surrounding photographs of Native Americans. Her simultaneous control and loss of control over her image-she posed for the photograph but did not consent to its publication-can be productively compared to Luna's performance. His "take a photo, leave a photo" policy permits audience members to go home with a souvenir photograph of themselves with Luna, while also ensuring that Luna comes away with a copy of the same image. There is a sense of reciprocity, in that both parties are given a copy of the photograph, and both are present in the image. But this reciprocity broke down in the 2010 performance due to the busy public area in which the work was staged. What Luna gained in terms of the symbolism of the site, he lost in terms of control over the dissemination of his work.

\footnotetext{
${ }^{20}$ Gerald V izenor, Manifest Manners : Narratives on Postindian Survivance (Lincoln: U niversity of Nebraska Press, 1999), vii.

${ }^{21}$ Mary Louise Pratt, Imperial Eyes : Travel Writing and Transculturation (London: Routledge, 1992 ), 6. Pratt approaches "contact zones" in terms of their relevance to language and literature, but the term has been more recently put to use in postcolonial theory and native studies.

22 Michelle H. Raheja, "Reading Nanook's Smile: V isual Sovereignty, Indigenous Revisions of Ethnography, and "A tanarjuat (The Fast Runner)" American Quarterly 59, no. 4 (December 2007): 1160.

${ }^{23}$ I bid., 1162.

${ }^{24}$ Lippard, Partial Recall, 31 . Benally's case is also briefly discussed in John Henry Merryman and A Ibert Edward Elsen, Law, Ethics, and the Visual Arts (New York: Kluwer Law International, 2002), 552-53. The federal district court dismissed the case because it lacked personal jurisdiction, and while an appellate court reversed the dis missal, it did not rule on the merits of the case.
} 
Photographs and film stills that document Luna's performance at the Columbus Monument show the artist, cutouts, and participants, with the addition of the photographers and gathered crowd (fig. 5). Documenting the audience and outdoor location is crucial to the 2010 iteration of Take a Picture; Luna reveals the continued perception that a real Indian can be discovered amongst the three characters he proffers. When Luna attired himself in khakis and a polo shirt he disrupted broad cultural expectations, becoming a member of the group Philip J. Deloria has termed "Indians in unexpected places." 25 By choosing instead to take a picture with Luna in his war dance regalia, participants upheld the problematic notion that Native Americans can only be seen one way, as romantic figures of peoples' past. Luna ensured that their choice designated this character the most "real" of the three Indian identities proffered, indicating that he must thus pose in this manner to gain himself a position in the realm of contemporary Western conceptions of the real. Luna does not aim to confirm or deny the realness of any depiction of Indian identity; he rather exposes the very concept of the real Indian as a construct with a complex visual history.

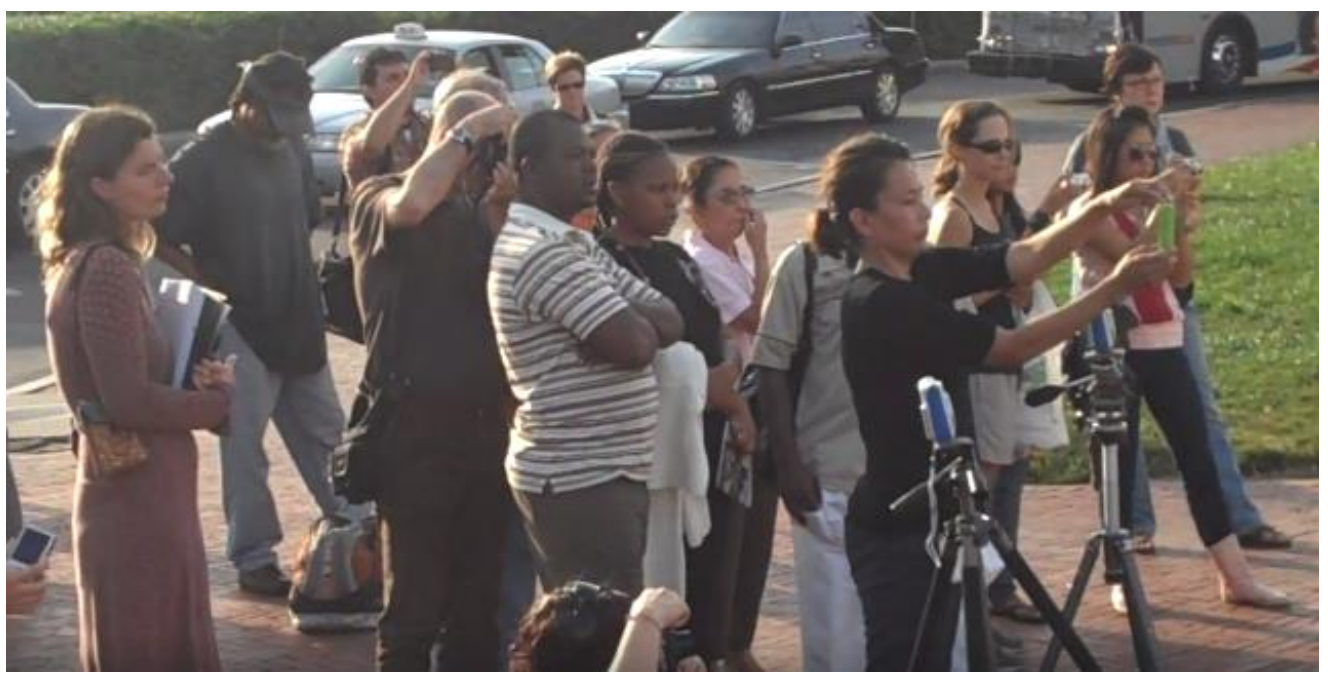

Figure 5

A udience documenting James Luna's Take a Picture with a Real Indian performed in 2010 , Was hington D.C. Film still from $\mathrm{N}$ ational Museum of the A merican Indian performance recording, accessed from http://www.facebook.com/video/video.php?v=10100243886416480

\section{Edward S. Curtis and the Legacy of the Pose}

Take a Picture draws on a long tradition of Native Americans being staged and staging themselves to fit Western audiences' expectations. Such preconceptions were both represented and produced by Edward S. Curtis's early-twentieth-century photographs of Native Americans. Luna has long been aware of Curtis and his methods: "Curtis's images were first highlighted for me in the late 1960's . . They represent that image of the Indian that people feel comfortable with and then, later on, I came to learn that some were posed,

${ }^{25}$ Philip J. Deloria, Indians in Unexpected Places (Lawrence, KS: U niversity Press of Kansas, 2004 ), 4. 
with the same regalia on two different guys, for example." ${ }^{26}$ His comments on Curtis's photographs and the conditions of their production necessitate a closer look at the se iconic yet problematic images.

Curtis's photographs have come to define Indian imagery to the extent that even now, as Luna's piece has documented, most viewers only see a real Indian before them if $\mathrm{s} / \mathrm{he}$ dresses in recognizably Native clothing. In anthropological terms, this attitude reflects the outdated idea of an ethnographic present, the artificial construction of a pre-contact people and the expectation that their modern descendants look and behave within the confines of the construction. ${ }^{27}$ Paige Raibmon notes that the fallacious notion of authenticity is judged by the degree to which Native peoples recognizably adhere to the expectation of this construction. ${ }^{28}$

Roland Barthes defines this culturally contingent recognition by way of the pose, a specific way of staging oneself, and/or the objects around oneself, to ensure that photographs conform to certain societal connotations. ${ }^{29}$ Curtis was adept at posing: he photographed Native Americans in artificially staged settings and stances, and he carefully culled his collection of markers of modernity before publishing his portfolio. Curtis a sserted at the start of his project, "above all, none of these pictures would admit anything which betokened civilization, whether in an article or dress or landscape or objects on the ground." 30

Like many of his contemporaries, Curtis viewed Native Americans as a "vanishing race," and he set out to document as many Native peoples as he could before their presumed extinction. In his published portraits of Native Americans, the sitters somberly stare out from the photos, with raking light thrown across their faces that gives all but the youngest sitters an aged appearance, as can be seen in Strike on his Head, Crow Indian, Montana (fig. 6). The figures in his photographs sit upright, giving their statures a kind of ethnographic, pseudo-scientific verity. ${ }^{31}$ Many of these portraits were, however, highly posed. Faris has described Curtis's "legacy of posing," noting that in his images of Navajos, the photos were "completely set up, using not only 'phony' costumes, additions, and poses .

\footnotetext{
26 James Luna, "James Luna," in Staging the Indian: The Politics of Representation, eds. Jill D. Sweet and I an Berry (Saratoga Springs, NY: The Tang Teaching Museum and A rt Gallery, Skidmore College, 2002), 73.

27 See Johannes Fabian, Timeand the Other: How Anthropology Makes Its Object (New York: Columbia University P ress, 1983).

28 Paige Raibmon, Authentic Indians : Episodes of Encounter from the Late-Nineteenth-Century Northwest Coast (Durham: Duke University Press, 2005).

${ }^{29} \mathrm{He}$ observes that when the pose is used, "the photograph clearly only signifies because of the existence of a store of stereotyped attitudes which form ready-made elements of signification." Barthes further notes that in the posing of objects, "the meaning comes from the objects photographed (either because these objects have... been artificially arranged in front of the camera or because the person responsible for lay-out chooses a photograph of this or that object)."Roland Barthes, "The Photographic Message," in Image - Music - Text, trans. Stephen Heath (London: Fontana Press, 1977), 22. In his analysis of posing, stereotypes, and the use of photography in identity formation, Barthes considers the photographic genre as a whole, not just images of Native peoples.

30 Edward S. Curtis, quoted in Hans Christian A dam, "Edward S. Curtis and the North A merican Indians," introduction to The North American Indian: The Complete Portfolios (New York: Taschen, 2001 ), 26.

${ }^{31}$ For analys is of these $O$ thering strategies, see Christopher M. Lyman, The Vanishing Race and Other Illusions: Photographs of Indians by Edward S. Curtis (Washington, D.C.: Smithsonian Institution Press, $1982), 61$
} 
. . but, indeed, in some cases, actual phony Navajo." 32 Not only did Curtis insist on removing any signifier of assimilated Western customs, he also emphasized their native-ness through the use of objects and activities that ancestral Navajos would have found as foreign as their descendants did, but that served as markers of real Indians for Western audiences. Catherine C. Robbins observes that "he posed Indians in the fashion of his time in sometimes fanciful contexts; his Hopi women ground corn in ceremonial dress." 33 In the photo to which she refers, four women kneel in the time-honored task of grinding meal, but instead of donning their typical day-to-day clothing, the women have adorned themselves in the jewelry, blouses, and side-buns usually reserved for ceremonial occasions (fig. 7). Whether they are doing so of their own accord or at Curtis's instruction, the activity is clearly staged: all four women are in the exact same position, as though the backbreaking work of producing cornmeal would be synchronized. A bowl of already ground meal has been placed in the center of the foreground, to further define the activity for uninitiated viewers. Nothing in the photograph is materially or temporally inaccurate, but the image collapses different facets of Hopi culture into one visually readable and formally pleasurable pose.

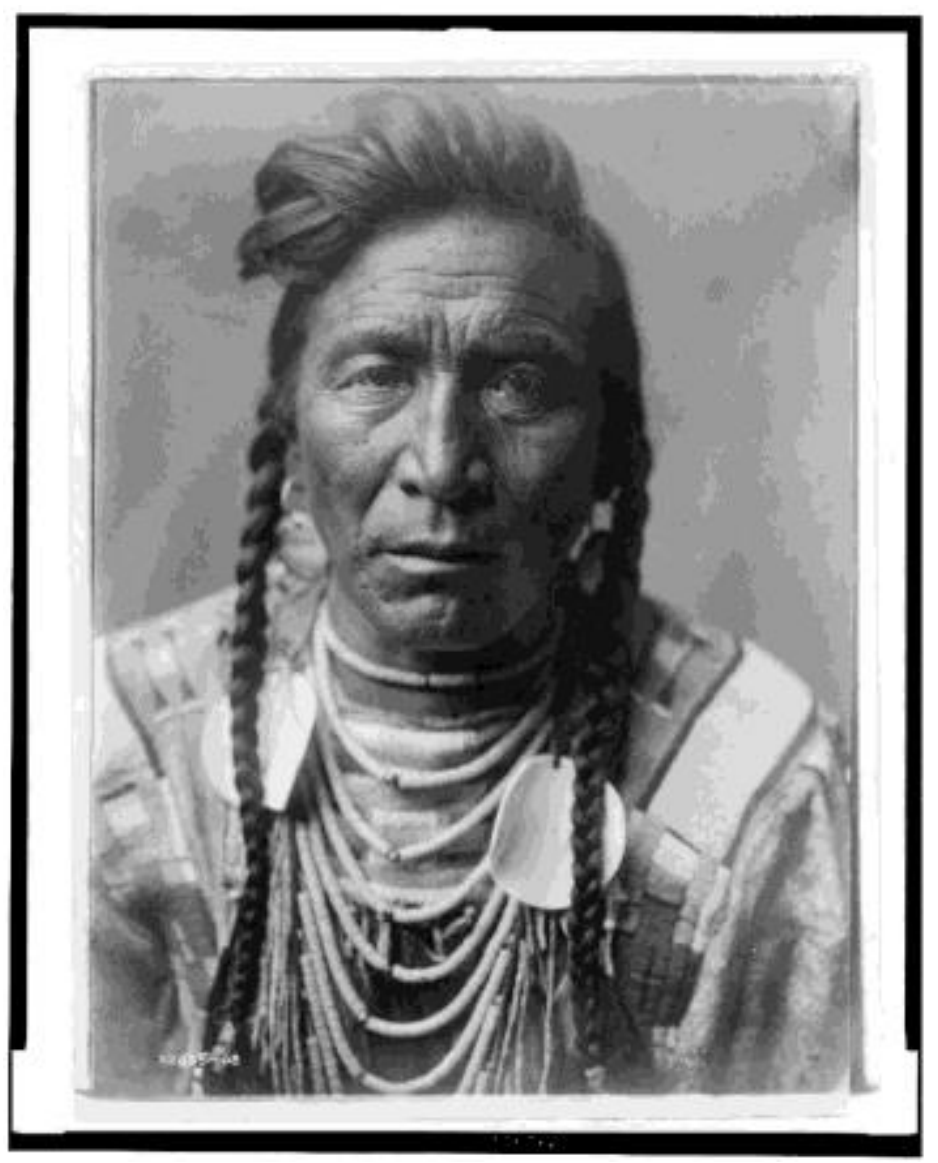

Figure 6

Edward S. Curtis, Strike on his Head, Crow Indian, Montana, ca.1908. Digital file from original. Library of Congress, Prints \& Photographs Division, Edward S. Curtis Collection, [LC-USZ62-106763].

\footnotetext{
32 Faris, Navajo and Photography, 107-108.

${ }^{33}$ Catherine C. Robbins, All Indians Do Not Live In Teepees (Or Casinos) (Lincoln: U niversity of Nebraska Press, 2011), 244-245.
} 


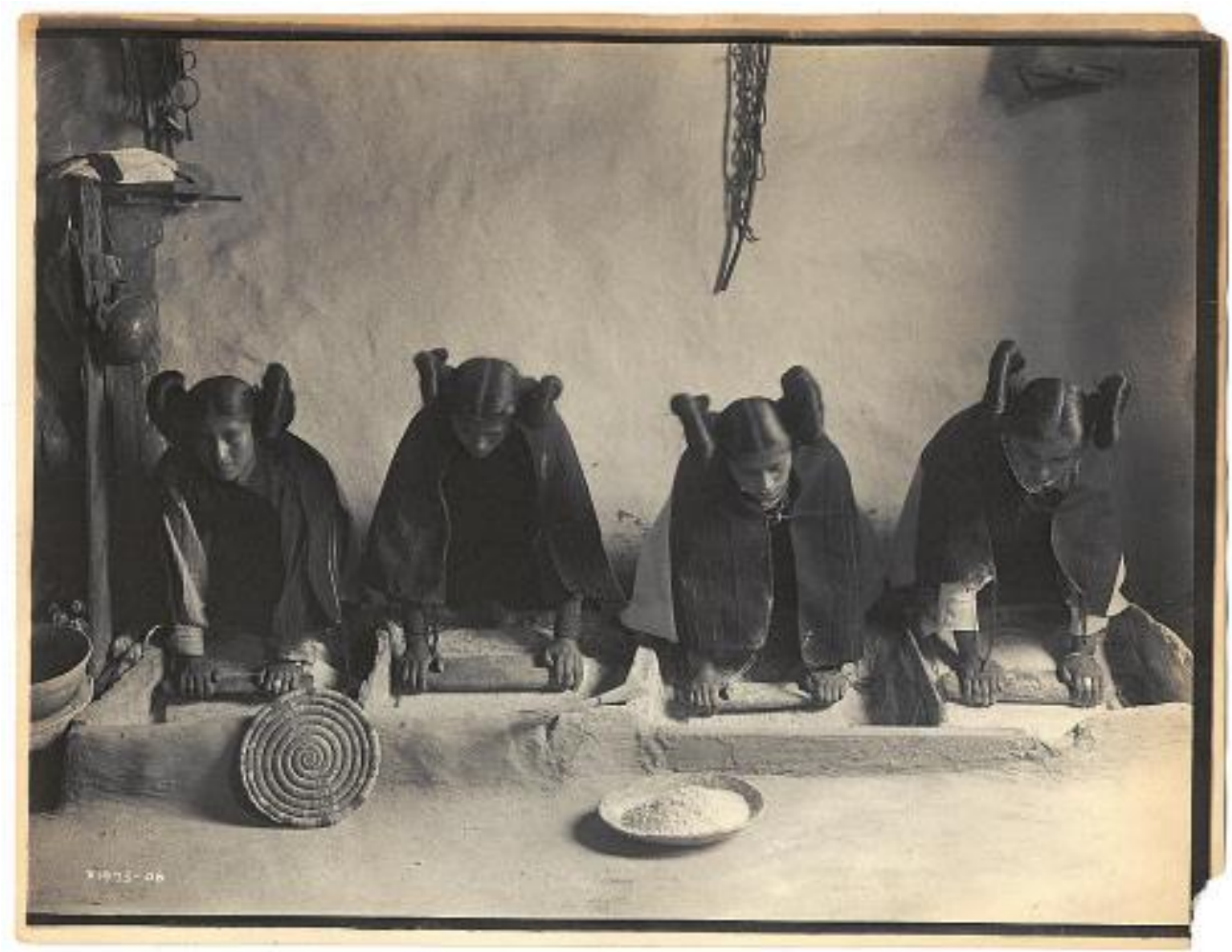

Figure 7

Edward S. Curtis, The mealing trough - Hopi, ca. 1906. Digital file from original. Library of Congress, Prints \& P hotographs Division, Edward S. Curtis Collection, [LC-DIG-ppmsca-05085].

Recent scholarship on Curtis seeks to move beyond the critique of his posing and staging activities because, as Aaron Glass notes, "it has tended to grant Curtis sole authorship and control, completely ignoring the active participation and possibly strate gic agency of the indigenous people who chose to sit and post and dress up for him." ${ }^{4}$ Glass instead examines the motivations of Kwakwaka'wakw sitters pictured in Volume Ten of Curtis's extensive book series The North American Indian. He focuses on George Hunt, a

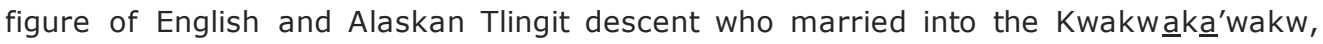
concluding that Hunt's own ethnographic interests as well as his desire to fit into his wife's culture likely influenced his decision to pose for Curtis. In a similar singular study of a sitter, Shamoon Zamir analyzes Curtis's portrait of Alexander B. Upshaw, a Crow man who studied at the Carlisle Indian School, married a white woman, and became a respected advocate for tribal rights (fig. 8). In earlier portraits, Upshaw is depicted in a suit and tie, hair neatly

\footnotetext{
${ }^{34}$ A aron Glass, "A C annibal in the A rchive: Performance, Materiality, and (In)V isibility in Unpublished Edward Curtis Photographs of the Kwakwaka'wakw Hamat'sa" Visual Anthropology Review 25, no. 2 (Fall 2009): 130 .
} 
parted. But in Curtis's photo, Upshaw sports a feathered Crow headdress as well as an elaborate Crow necklace over his bare chest.

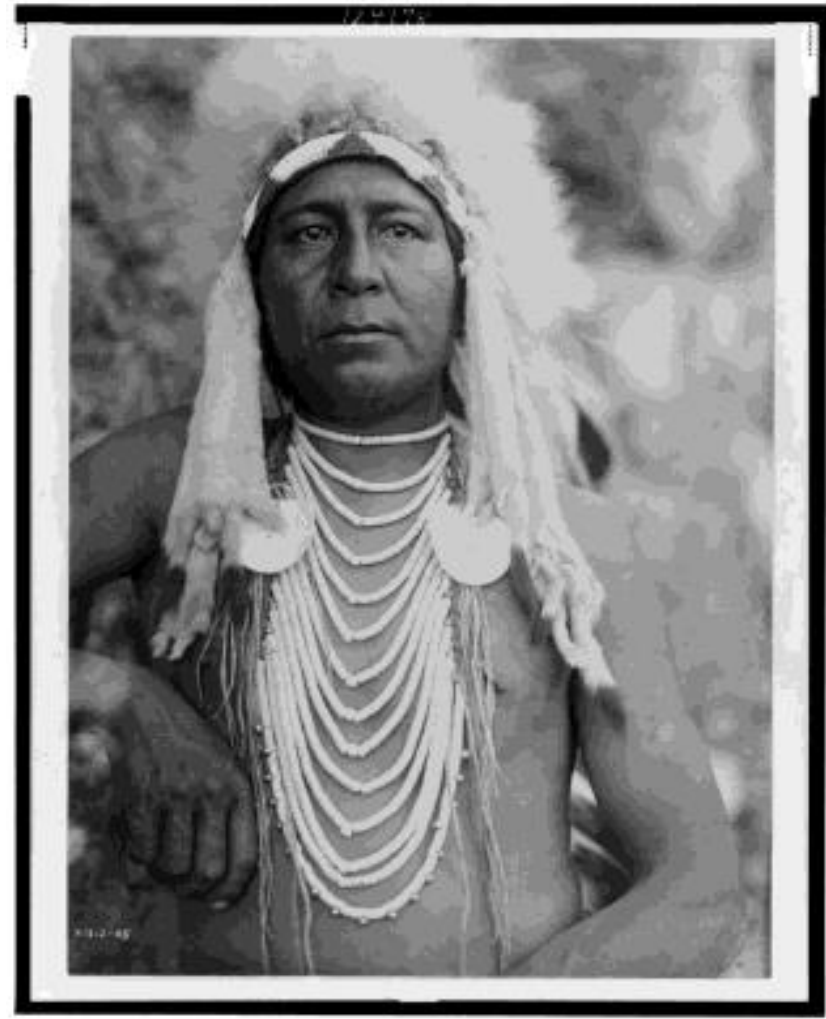

Figure 8

Edward S. Curtis, Ups haw - Aps aroke. ca. 1905 . B\&W film copy negative. Library of Congress, P rints \& Photographs Division, Edward S. Curtis Collection, [LC-USZ62-124178].

If Luna's Take a Picture voids the validity of the designation real Indian, so too does Upshaw's attire. Noting the precipitous drop in the Crow population and the cultural practices that had atrophied or been outright banned by the American government, Zamir argues that for Upshaw, "the donning of costumes and the rehearsal of tribal beliefs and practices . . . constituted a use of tradition to legitimize a contemporaneous project of social, economic, and political survival." ${ }^{35}$ He further observes that for figures like Upshaw, "the border between 'invented' and 'lived' tradition was no doubt a fluid one, if it was experienced as real at all." ${ }^{\prime 36}$ Curtis may have posed his sitters, but they also participated in active self-fashioning that affirmed Native tradition as a part of-rather than a negation of-Native modernity. The descendants of these sitters are often thankful to have these images. Gros Ventre curator George P. Horse Capture, whose grandfather was photographed by Curtis, declared: "Real Indians are extremely grateful to see what their ancestors look like or what they did and we know they are no stereotypes. No one staged the people. And we see them at their classic finest." ${ }^{13}$

\footnotetext{
${ }^{35}$ Shamoon Zamir, "Native A gency and the Making of The North American Indian: A lexander B. Upshaw and Edward S. Curtis" American Indian Quarterly 31, no. 4 (Fall 2007), 637.

${ }^{36}$ Ibid., 637.

${ }^{37}$ George P. Horse Capture, Foreword to Native Nations : First Americans as Seen by Edward S. Curtis, ed. Christopher Cardozo (Boston: Little, Brown and Company, 1993), 17.
} 


\section{The Archival Logic of the Museum}

Ethnographers also photographed Luna's ancestors. In the interest of illustrating her article on Luiseño Indians, Constance Goddard DuBois took a photo of Luna's greatgrandmother Maria Soledad Apish Trujillo and her young daughter (fig. 9). ${ }^{38}$ Unlike Curtis, who had artistic as well as ethnographic intentions, DuBois allowed elements of Western influence to enter the image just as they had the lives of the people she was documenting. Trujillo and her daughter are thus pictured in the cotton dresses that had become typical day-to-day wear for many Native American women by the turn of the twentieth century. Nonetheless, Trujillo's posture is rigid and her expression somber, conveying the same kind of ethnographic verity that Curtis sought in his portraits. Whether or not Trujillo was instructed by DuBois on the proper position to assume, her young daughter's inquisitive look and the half-hidden presence of a young boy curiously looking on from the shadows add a familial, human element to an otherwise ethnographically distancing pose.

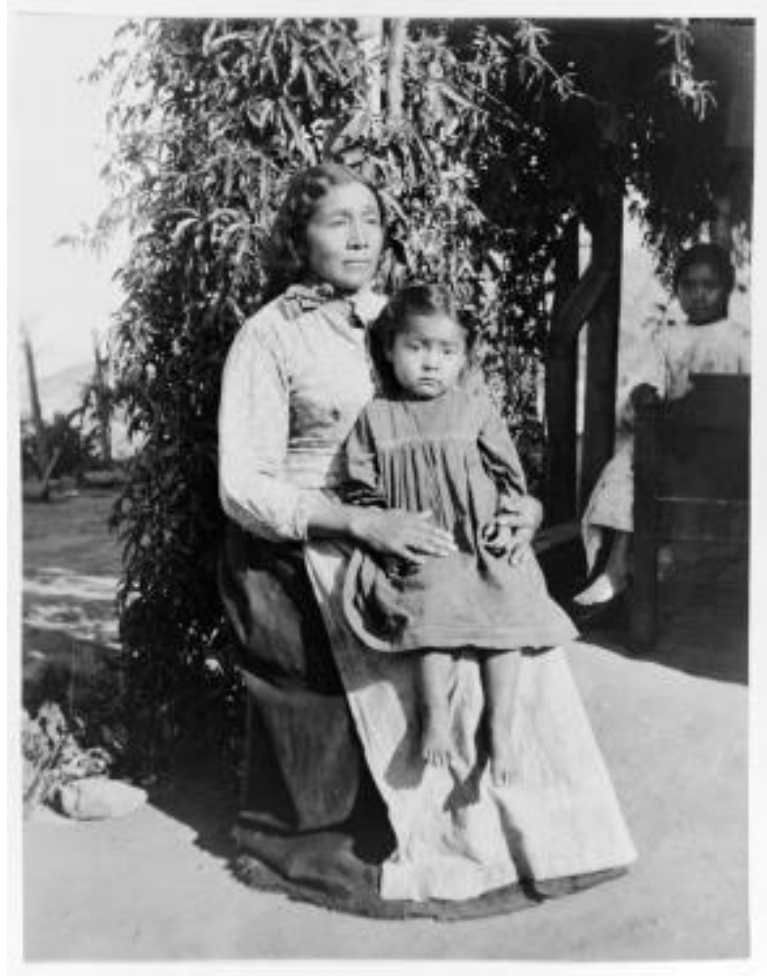

\section{Figure 9}

Constance Goddard DuBois, Trujillo's Wife \& Children, Potrero (Valley Center, San Diego County, California) 1906. Contact print on photographic paper, $5 \times 4$ in. Constance Goddard DuBois Collection, San Diego Museum of Man. Copyright 2016 San Diego Museum of Man.

To see this photograph, Luna must visit the San Diego Museum of Man where it has been categorized, catalogued, and duly archived. Jane Blocker has effectively discussed Luna's oeuvre in archival terms. She concentrates her analysis on The Artifact Piece (1987), a work first staged at the same institution housing the photograph of Luna's great

\footnotetext{
${ }^{38}$ Constance Goddard DuBois, "The Religion of the Luiseño Indians of Southern California" University of California Publications in American Archaeology and Ethnology 8, no. 3 (Berkeley: The University Press, 1908).
} 
grandmother, linking ethnographic interest in his ancestors to the continued Western epistemological obsession with archiving the Other (fig. 10). ${ }^{39}$ In the work, Luna, slightly sedated, lay wearing a breechcloth in a sand-covered museum display case, his body framed by museum labels that rhetorically ruptured romantic preconceptions of the Indian. For example, one described an unsuccessful marriage, stating: "Skin callous on ring finger remains, along with assorted painful and happy memories." The description of a physical callous and the memories it evokes for the artist brought Luna's Native body into the present and his life into the contemporary context, as did one of the vitrines placed near his body (fig. 11). Contained within was a personal potpourri of mementos from the artist's own history, including a driver's license, diploma, divorce papers, tapes and records of contemporary musicians, political buttons, comic books, and small figurines. ${ }^{40}$ By providing information about Luna's own life, the placards and the vitrine spoke to what Serge Gruzinski has called the mestizo mind and Blocker terms a history of mélange; that is, a society that exhibits ambiguously ambivalent signs of a composite cultural identity. ${ }^{41}$ Such signs are generally repressed in the institutional context to what Jean Fisher calls "the necrophilous codes of the museum." ${ }^{42}$ Museums' visual and rhetorical cues often represent indigenous peoples as anachronistic to modern life, perpetually vanishing because they are characterized as already of the past. As Blocker notes, the Western institutional archive favors bones over flesh, the ancients over their living descendants. ${ }^{43}$

Luna's intervention was thus to rupture this archival assumption of pastness by bringing his own bodily presence into the museum, emphasizing the present by parodying the institutional insistence on the past. ${ }^{44}$ Performance proves a particularly apt strategy for disrupting the Western fantasy of the "vanishing race," for, as Peggy Phelan notes, absence always underlies the presence of performance. ${ }^{45} \mathrm{Her}$ point is particularly poignant for Native performers who stage the constructed aspect of Native identity, as their a udiences often paradoxically view them as part of a vanished culture, despite the performers' physical presence. If Take a Picture insists on the presence of a khakis-clad contemporary Native American even while highlighting the way in which most audience members designate the regalia that of the real Indian, The Artifact Piece stresses the lived presence and physical

\footnotetext{
39 Jane Blocker, "A mbivalent Entertainments: James Luna, Performance, and the A rchive," Grey Room 37 (Fall 2009): 55-62.

${ }^{40}$ For a more complete list, see Jennifer A. Gonzalez, Subject to Display: Reframing Race in Contemporary Installation Art (C ambridge, MA: The MIT Press, 2008), 40.

${ }^{41}$ Serge Gruzinski, The Mestizo Mind: The Intellectual Dynamics of Colonization and Globalization, trans. Deke Dusinberre (New York: Routledge, 2002), 9; Blocker, 61. These terms are part icularly pertinent in discussing Luna's work, as he identifies as both Luiseño and Mexican-American has addressed his multiple racial identities in other works.

42 Jean Fisher, "Jimmie Durham," in Matoaka Ale Attakulakula Anel Guledisgo Hnihi, exhibition catalogue (London: Matt's Gallery, 1988), 12.

43 Blocker borrows her use of the "flesh over bone" archival logic from Rebecca Schneider, who asserts that, "in the archive, flesh is given to be that which slips away. Flesh can house no memory of bone. O nly bone speaks memory of flesh." Blocker, 54; Rebecca Schneider, "A rchives: Performance Remains" Performance Research 6, no. 2 (Summer 2001): 102.

${ }^{44}$ He does so by way of the pose and, though I do not discuss them here, mimicry and masquerade - and the discourses surrounding such strategies-are also important aspects of his work. A rtis ts with feminist agendas have long used these strategies; indeed, Luna learned them from Eleanor Antin, a feminist artist and instructor at the University of California, I rvine while he was a student there.

45 Peggy Phelan, Unmarked: The Politics of Performance (New York: Routledge, 1993), 146-166.
} 
present-ness of a contemporary Native American through the stereotypical staging methods of the museum, which are usually used to stress the historical past-ness of the cultures on display. Luna asserts Native agency by parodying the typical lack thereof in the institutional context.
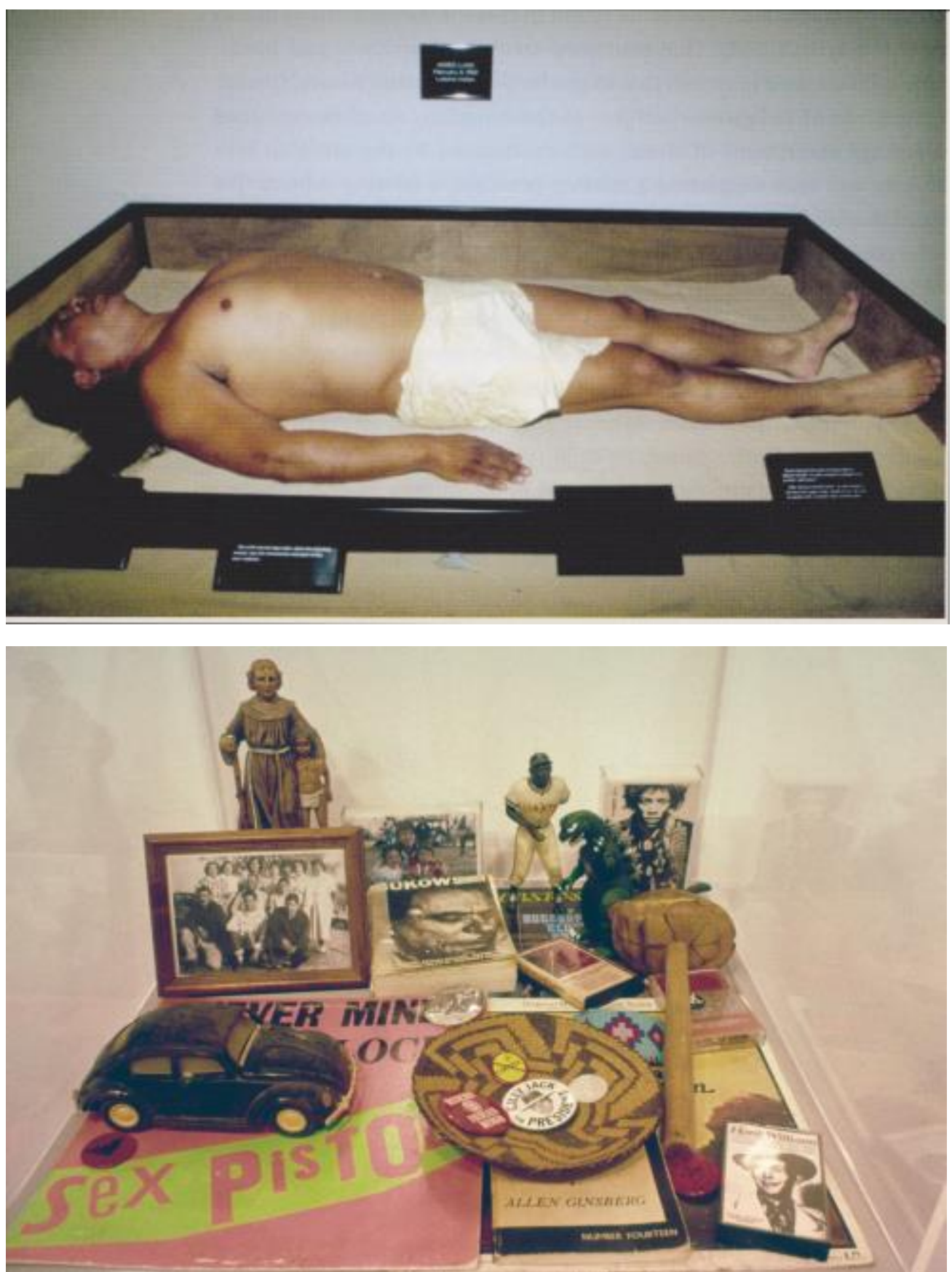

Figure 10

James Luna, The Artifact Piece, installation view, 1987. Live performance-installation, San Diego Museum of Man. Photographer unknown. Copyright 2016 San Diego Museum of Man.

\section{Figure 11}

James Luna, The Artifact Piece, installation view (vitrine), 1987. Live performance-installation, San Diego Museum of Man. Photographer unknown. Copyright 2016 San Diego Museum of Man. 


\section{Luna's Contemporaries}

Luna's work is often compared to Coco Fusco and Guillermo Gómez-Peña's Two Undiscovered Amer-Indians Visit the West (1992-1994), another performance piece that plays off stereotypes of essentialized Native identity in order to reveal them as such. In the work, the artists presented themselves as Amer-Indians from an island in the Gulf of Mexico that had somehow escaped Western discovery (fig. 12). In various public spaces such as museums, public squares, universities around the world, they had themselves presented in a cage containing assorted material markers of their fictional everyday lives. So-called experts were on hand to answer questions about them. Like the vitrine of contemporary objects included in Luna's The Artifact Piece, Fusco and Gómez-Peña's performative project included a number of props that applied pressure on the notion of indigenous a uthenticity; to urist badges, plastic sunglasses, a laptop, a bottle of Coca-Cola and more made up what Caroline Vercoe calls "their living cargo-culture diorama." 46 Fusco recalls that upon seeing this assortment, "a Native American elder from the Pueblo tribe of Arizona . . . said that our performance was the most real thing about the Native Americans displayed in the whole museum. He said the installation and performance ought to be permanent to give people a very clear idea of the Native American experience. ${ }^{\prime 47}$ However, other viewers questioned the legitimacy of Natives possessing commercial items. The artists were surprised by the negative reactions. While they assumed their commentary would be clear as a construct, many people engaged with the performance believing that the artists actually were Natives from Guatinaui, their fictional homeland.

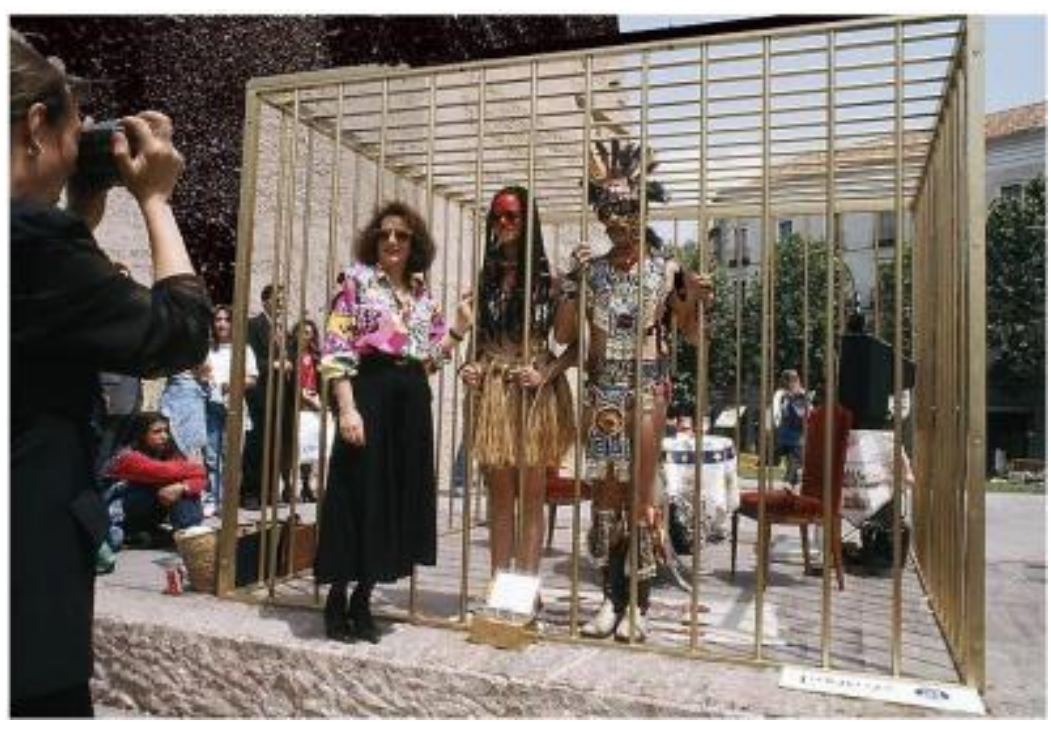

Figure 12

Coco Fusco and Guillermo GómezPeña, Two Undiscovered Amer-Indians Visit the West, 19921994. Live performanceinstallation, Columbus Plaza, Madrid, Spain. Copyright Coco Fusco.

\footnotetext{
${ }^{46}$ Caroline Vercoe, "A gency and A mbivalence: A Reading of Works by Coco Fusco," in The Bodies that Were Not Ours, and Other Writings, ed. Coco Fusco (New York: Routledge, 2001), 233.

${ }^{47}$ Coco Fusco, qtd. in A nna Johnson, "Coco Fusco and Guillermo Gómez-Peña" Bomb 42 (Winter 1993), accessed May 4, 2012, http://bombsite.com/issues/42/articles/1599.
} 
Part of the performance involved the sale of Polaroid images to audience members who posed with the so-called savages for souvenir pictures, a strategy that links the project to Luna's Take a Picture-which he had performed just one year before Fusco and Gómez-Peña first staged Two Undiscovered Ameri-Indians-and points to a Western history of using the Othered body for entertainment. Luna's contemporary Zig Jackson (Mandan, Hidatsa, Arikara) also bitingly commented on the continued tourist tendency to photograph traditional Native American culture in his Indian Photographing Tourist Photographing Indian series from 1991 (fig. 13). ${ }^{48}$ The tourists, clad in cargo shorts, blue jeans, and anoraks, view the ceremonial dance through their expensive cameras, clicking away, seemingly oblivious to their own intrusion and Jackson's doubled documentation. Formally, the layering of lens views in his images echoes those of images taken by bystanders of Luna's Take a Picture as well as Navajo Children; in each instance the resulting imagery shows Native bodies being photographed. The identities of the photographers documenting the Native peoples, and the photographers documenting the documenters shift from photo to photo, but the Native body as Other is central to all three images both pictorially and rhetorically.

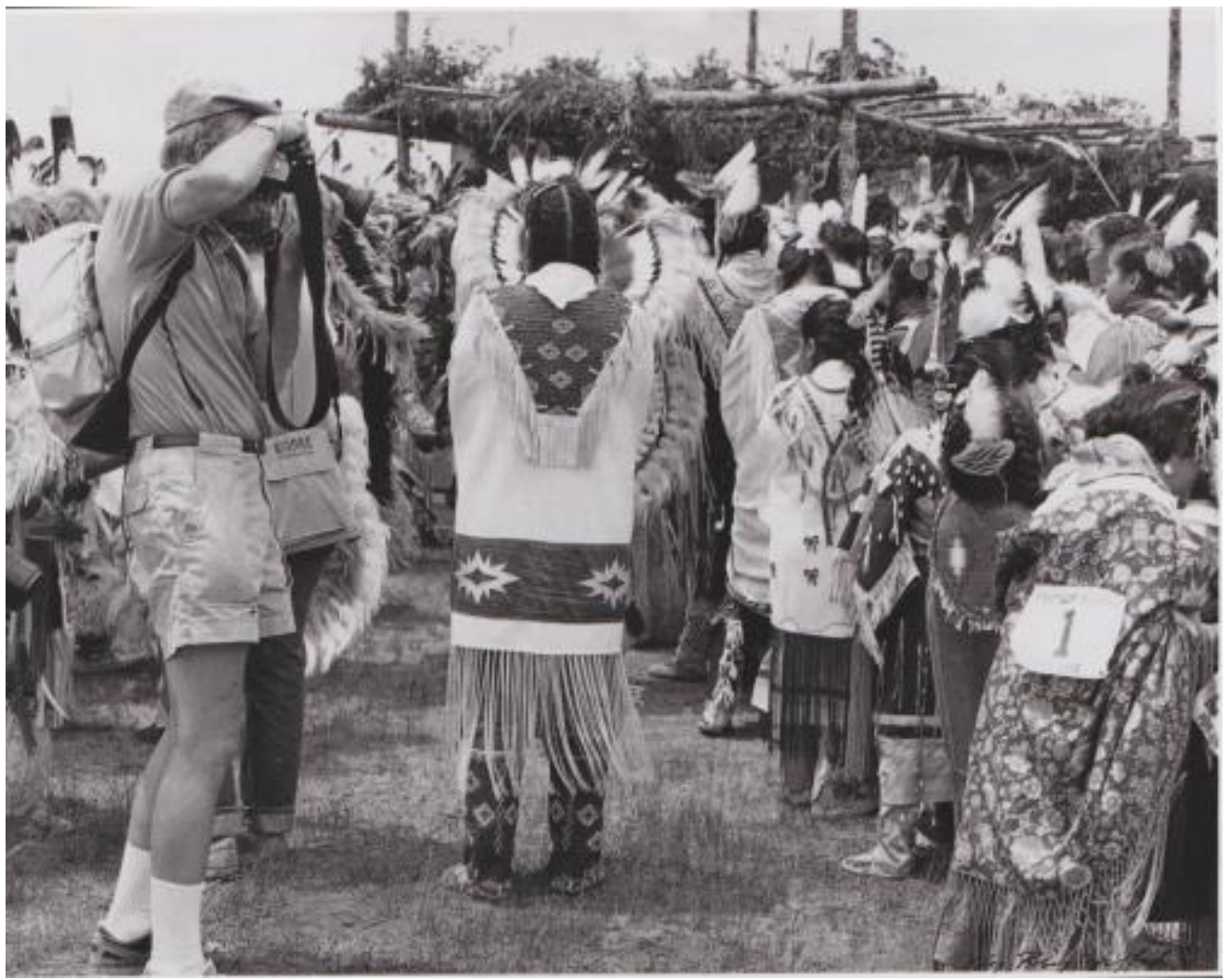

Figure 13

Zig Jackson, Untitled from Indian Photographing Tourist Photographing Indian series, 1991. Silver gelatin print, $16 \times 20 \mathrm{in.} \mathrm{Image} \mathrm{courtesy} \mathrm{of} \mathrm{Zig} \mathrm{Jackson.}$

\footnotetext{
${ }^{48}$ For more on this project, see "Social I dentity: A V iew from Within, P hotographs by Zig Jackson," in Strong Hearts: Native American Visions, ed. Peggy Roalf (N ew Y ork: A perture, 1995), 34 -37.
} 


\section{Conclusion}

James Luna's oeuvre accommodates the historiographical shift in discourse on images of Native Americans from the exploited Native body towards the more complex account of indigenous agency. Examining the work-and the evolving reception thereof-of Native American artists like Luna allows for a nuanced analysis of this shift, and illuminates the role that indigenous cultural producers have played in steering the dialogue towards an acknowledgement of Native agency. Explaining the impetus behind Take a Picture, Luna stated, "I saw some Indian selling his red ass to sell jewelry, and I was ashamed but I knew what he was doing - he was working. I've worked too . . . as Indians we have all been on the tourist line. ${ }^{\prime 49}$ His sentiment echoes that of Paul Chaat Smith, who describes the experience of being a Native American as partially "our own frequent willingness to lead the searchers in their quest for the real Indian." 50 Viewed sequentially, the various iterations of Take a Picture thus bring to light dual visual historical narratives: the stereotypical depictions of Native Americans by non-Natives, and the way Native Americans have posed themselves to fit and challenge these Western stereotypes.

The history of Native self-staging to fit Western expectations productively problematizes a shortsighted reading of Luna's work. Louis Kaplan argues that, "if we take a picture of another person or of a group, we pose them in a relationship with exteriority-exposing them to the look of others and even to themselves as other." 51 The complex relationships between identity, agency, and the Other-particularly as enacted in the pose and the photograph-are fraught for Native Americans whose past continues to be colonized by Western representational epistemologies that encroach on their lived present. Yet, as Catherine Robbins notes, echoing George Horse Capture's appreciation for Curtis's photographs, "some of Curtis's 'vanishing' Indians-alive and well today-admire his portraits." 52 Posed though they may be, photographs like Curtis's are a part of Native A merican history and can be admired for their visual pleasure, even with an awareness of their construction. ${ }^{53}$ Extrapolating from an earlier version of Take a Picture, Blocker asserts that, "even as the ethnographer, curator, and historian take a picture, they also leave a picture." 54 In her estimation, this "trade," while potentially exploitative, allows for continued Native presence in the face of "a visual discourse working hard to make them disappear. "55 C haracterizing such interactions as a "trade" acknowledges the agency of Native Americans who may have strategically posed for documentary photographs. Indeed, even while Curtis characterized his sitters as the "vanishing race," those sitters insisted on their continued existence, their survivance, by agreeing to pose for him. Regardless of the participants' selection of real

\footnotetext{
${ }^{49}$ Luna, quoted in Blocker, "Failures of Self-Seeing: James Luna Remembers Dino," PAJ: A Journal of Performance and Art 23, no. 1 (January 2001), 31.

${ }^{50}$ Smith, "Ghost in the Machine," 9.

51 Louis Kaplan, "Being Exposed: Thinking Photography and Community in Spencer Tunick's Naked World Through the Lens of Jean-Luc Nancy," in Photography: Theoretical Snapshots, eds.J.J Long, Andrea Noble, and Edward Welch (New York: Routledge, 2009), 128.

52 Robbins, All Indians, 245.

53 In a way, such posing was inevitable; Lippard notes that "the pose is an imposition, since Native people had not traditional way of sitting for a portrait or a photograph; self-representation in that sense was not part of the cultures." Lippard, Partial Recall, 39.

54 Blocker, "A mbivalent Entertainments," 73.

55 Ibid.
} 
Indian to be photographed with in Take a Picture, Luna's very presence reminds his audience that Native peoples have not disappeared.

While the photograph and the pose are key to Luna's Take a Picture, the multiple performances of the work also necessitate a consideration of different forms of reenactment. Colloquially speaking, to reenact is simply to act or perform a gain. In this sense, Luna can be seen to reenact two aspects of reenactment: First, since most audience members elect to have their photograph taken with Luna in a headdress, the performance can be interpreted as a reenactment of stereotypical Western conceptions of the real Indian. Second, Luna's purposeful participation in this performance indicates that it is a reenactment of the way Native Americans have frequently re-appropriated Western stereotypes for various reasons.

But these forms of reenactment could be carried out with a single performance; the multiple restaging points to a third and fourth aspect of reenactment pertinent to Luna's work: Thirdly, Luna insists on the enduring presence of the so-called vanishing race by continuing to reenact Take a Picture, for while absence may underlie the presence of performance, performances that are staged again and again disrupt disappearance. Finally, because no performance can ever be repeated exactly, and no performance can ever replicate past attitudes exactly, reenactments have an emancipatory potential. In his Debordian essay "An Arena in which to Reenact," Sven Lütticken notes: "Operating within contemporary performative spectacle, if from a marginal position, art can stage small but significant acts of difference. From this perspective, historical reenactment and living history too may constitute a potential waiting to be activated." 56 In this sense, Take a Picture does not just re-inscribe stereotypical attitudes through reenactment. Rather, the restag ing of the performance allows for intervention, for potentially changing these attitudes. Luna's staging strategy for Take a Picture thus far seems to encourage viewers to choose the character in regalia as the real Indian, thereby pointing to the continued circulation of Native American stereotypes. Yet the work also provides for potentially different reactions: despite pushing viewers to choose his regalia-attired Indian, Luna seems to paradoxically hold a simultaneous expectation with each restaging that this time, the outcome will be different. While stereotypic imagery will always be a part of Native American history, future attitudes regarding Native Americans may change. Perhaps in performances of Take a Picture with a Real Indian yet to come, audience members' choices will be more evenly distributed amongst the three constructions of Indian identity; since the very designation "real Indian" is a fallacy, none of these constructions represent the real Indian, and yet, in a way, they all do.

\footnotetext{
56 Sven Lütticken, "An A rena in Which to Reenact," in Life, Once More: Forms of Reenactment in Contemporary Art (Rotterdam: Witte de With, Center for Contemporary Art, 2005), 60.
} 
$(\mathrm{cc})$ BY

New articles in this journal are licensed under a Creative Commons Attribution 4.0 United States License.

\section{UILIS D-Surle}

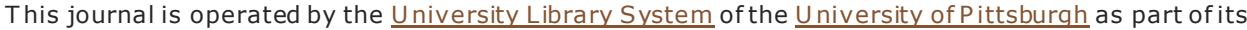
D-Scribe Digital Publishing Program, and is co-sponsored by the University of Pittsburgh Press. 


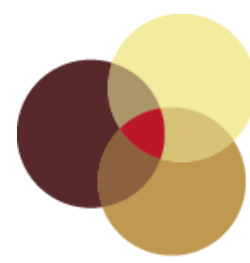

Vol 5, No 1 "Agency in Motion" (2016) | ISSN 2155-1162 (online) | DOI

\title{
Photographs of the "Dust of the Highway" Georgiana Goddard King's Way of Saint James
}

Annemarie Iker

\begin{abstract}
This article explores the use of photography in American art historian Georgiana Goddard King's The Way of Saint James (1920). King's genre-defying book on the Camino de Santiago pilgrimage intertwines art historical insights with literary commentary, historical examinations, geographical observations, and travelogue. But despite King's rich, groundbreaking scholarship on medieval Spain in The Way of Saint James and other monographs, her legacy has been overshadowed by subsequent art historians, chief among them her peer Arthur Kingsley Porter. Here, it is suggested that King's emphasis in The Way of Saint James on personal experiences of pilgrimage-both historical and contemporarydiminished the value of her work in the eyes of her colleagues, particularly when compared with Porter's supposedly objective studies. These differences in approach to the Camino de Santiago, visually manifest in King's and Porter's respective deployment of photographic evidence, have implications for medieval, historiographic, and feminist art historical inquiries.
\end{abstract}

\section{About the Author}

Annemarie Iker is a doctoral student in the Department of Art and Archeology at Princeton University. She received her MA in Art History from Williams College. Her research focuses on artistic and scholarly connections between southern Europe, northern Europe, and the Americas in the nineteenth and twentieth centuries, and she has a special interest in the historiography of Spanish medieval art. 


\section{Photographs of the "Dust of the Highway"} Georgiana Goddard King's Way of Saint James

Annemarie Iker

Following the mysterious disappearance of art historian Arthur Kingsley Porter from the coast of Donegal, Ireland in 1933, his former doctoral student Kenneth Conant mourned the loss of "one of the truly great medievalists of our time."1 Conant, by then a professor of architecture at Harvard University, credited Porter (b. Stamford, CT, 1883; d. Inishbofin, Ireland 1933) with challenging the regional classifications governing the study of early medieval art and architecture. Through monographs like Romanesque Sculpture of the Pilgrimage Roads (1923) and Spanish Romanesque Sculpture (1928), Porter expounded a model of stylistic development and transmission facilitated by the pilgrimage to Santiago de Compostela, in the Spanish province of Galicia. "Of enduring value," Conant noted, "was his new emphasis on the importance of Spain." 2

While Porter is remembered today as an-if not the-American leader in the study of Spanish medieval art and architecture, the Iberian Peninsula was hardly "new" to Georgiana Goddard King (b, West Columbia, WV, 1871; d. Los Angeles, CA, 1939), founding chair of the department of art history at Bryn Mawr College (fig. 1). ${ }^{3}$ A path-breaking art historian, King taught the first graduate courses on Spanish art in the United States and produced scholarship of noted breadth, depth, and ingenuity.

King's intellectual commitment to the Iberian Peninsula long predates the 1923 publication of Porter's Romanesque Sculpture of the Pilgrimage Roads. By 1923, King had already released an annotated edition of George Edmund Street's Gothic Architecture in Spain (1914); a scholarly re-issue of Street's writing, George Edmund Street, Unpublished Notes and Republished Papers (1916); A Brief Account of the Military Orders in Spain (1921); and a three-volume text on the Camino de Santiago, The Way of Saint James (1920). ${ }^{4}$ In addition to these book-length studies, King, also prior to 1923, had published numerous articles on Spanish castles, cloisters, and churches in the most distinguished

1 Kenneth Conant, "Arthur Kingsley Porter," Speculum 9 (1934): 95.

2 Ibid.

3 Scholars began to revisit King's legacy at the turn of the twenty-first century. See Madeline H. Caviness, "Seeking Modernity Through the Romanesque: G.G. King and E.H. Lowber Behind a Camera in Spain C. 1910-25," Journal of Art Historiography 11 (2014): 1-30; Alba del Pozo García, "Una pionera de hispanismo: Georgiana Goddard King (1871-1939)," Informes USA 14 (2013); Ana Hernández, "Georgiana Goddard King (1871-1939), pionera de la Historia del Arte medieval en Galicia," in As mulleres na Historia de Galicia. Actas do I Encontro Interdisciplinar de Historia de Xénero, ed. Miguel García-Fernández, Silvia Cernadas Martínez, Aurora Ballesteros (Santiago de Compostela: Andavira, 2012), compact disc; Hernández, "Saint Mary of Melón por Georgiana Goddard King," Quintana 7 (2008): 203-207; Janice Mann, "'Hark the Herald Angels Sing': Here's to Georgiana Goddard King (1871-1939)" in Women Medievalists and the Academy, ed. Jane Chance (Madison, WI: University of Wisconsin Press, 2005), 111-126; Mann, "Georgiana Goddard King and A. Kingsley Porter Discover the Art of Medieval Spain," in Spain in America, ed. Richard L. Kagan (Champaign, IL: University of Illinois Press, 2002), 171-192; and Susanna Terrell Saunders, "Georgiana Goddard King (1871-1939): Educator and Pioneer in Medieval Spanish Art" in Women as Interpreters of the Visual Arts, 1820-1979, ed. Claire Richter Sherman and Adele M. Holcomb (Westport, CT: Greenwood Press, 1981), 209-238.

4 Note that King appears to have largely completed The Way of Saint James in 1917 when she submitted the manuscript to her editors. She further edited the manuscript in 1919 while in Spain. See Caviness, "Seeking Modernity Through the Romanesque," 18. 
academic journals in the United States. ${ }^{5}$ As her Bryn Mawr colleague Harold Wethey would observe in King's obituary, American art historical scholarship on Spain flourished under Porter and his followers. But if Porter came to overshadow King in her lifetime, and eventually, to eclipse her entirely, it was not always so: "The American pioneer in this rich field was a woman," wrote Wethey, "Professor Georgiana Goddard King." ${ }^{6}$

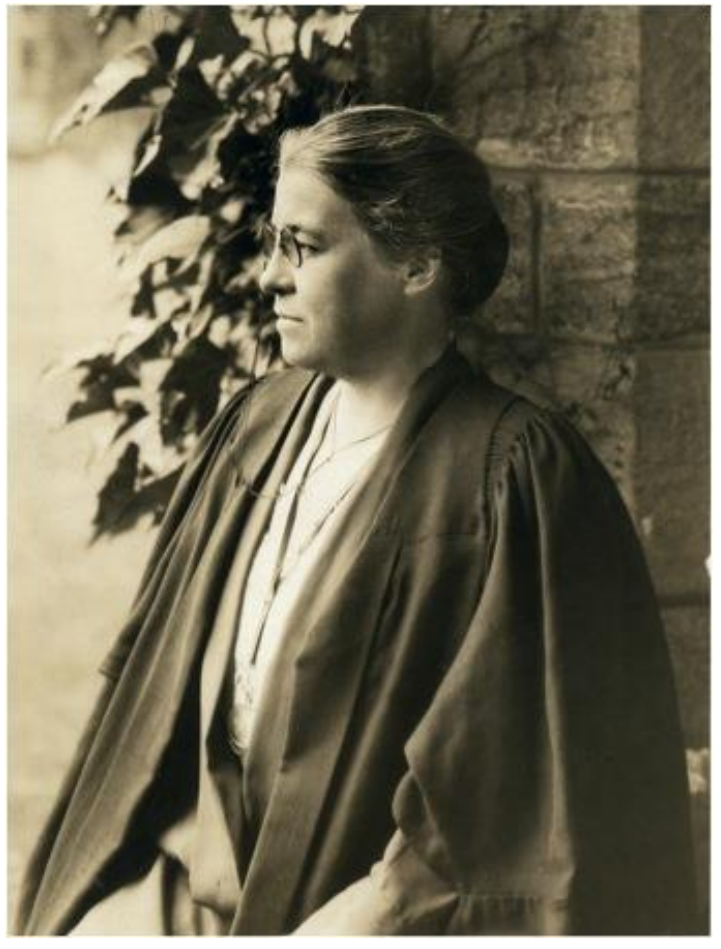

\section{Figure 1}

Unidentified photographer, Professor Georgiana Goddard King at Bryn Mawr College, c. 1910 . Special Collections, Bryn Mawr College Library, Bryn Mawr, PA. Courtesy Special Collections, Bryn Mawr College Library.

King's obscurity relative to Porter, ironically, may be attributed to her best-known book, The Way of Saint James. Across three illustrated volumes, King explores the monuments and traditions of the Camino de Santiago. Early reviewers noted that The Way of Saint James interlaces art history with literature, history, archeology, folklore, geography, and travelogue, forming King's "own personal genre."7 The resulting weave is thick, with each strand maintaining its apartness. The close formal analysis of monasteries, churches, and cathedrals along the Camino de Santiago lies beside the recounting of long-ago battles, recitation of archaic poems, description of landscapes, and even reports of the author's present-day dealings with her fellow pilgrims. Indeed, King acknowledges in the introduction

5 Among early articles published by King are: "Three Unknown Churches in Spain," American Journal of Archaeology 22 (1918): 154-165; "Spanish Cloisters," Journal of the American Institute of Architects 7 (1919): 481-8; "Castles in Spain," Journal of the American Institute of Architects 10 (1921): 377-382; and "Some Churches in Galicia," Art Studies 1 (1923): 55-64. In 1923-the same year as the publication of Porter's Romanesque Sculpture of the Pilgrimage Roads-she published Sardinian Painting (New York: Longmans, Green and Co.); the following year, the long-researched Pre-Romanesque Churches of Spain (New York: Longmans, Green and Co.); and in 1927, Mudéjar. In 1941, her Heart of Spain, a collection of essays edited by Agnes Mongan, was published posthumously.

6 Harold E. Wethey, "An American Pioneer in Hispanic Studies: Georgiana Goddard King," Parnassus 11 (1939): 33.

7 Ibid. 
to The Way of Saint James that the aim of her project shifted considerably from start to finish:

The intention, as the reader will see, has grown long since from a mere pedantic exercise in architecture, to a very pilgrimage, to following ardently along the ancient way where all the centuries have gone. ${ }^{8}$

Over the course of The Way of Saint James, King forgoes "mere pedantic exercise[s] in architecture" for evocation, and impartiality for ardor. ${ }^{9}$ Most significantly, she grants the same attentiveness to sensory apprehension and shifting internal states as she does to art and architecture. Choir screens, vaults, and tympana yield often to the chronicling of experience-to, as King intended, the "very pilgrimage" itself.

King, in The Way of Saint James, and Porter, in Romanesque Sculpture of the Pilgrimage Roads, trace the same pilgrimage road. Nonetheless, their scholarship diverges sharply in focus, perspective, and tone. Porter himself broached this divergence in a review of his student Conant's Early Architectural History of the Cathedral of Santiago de Compostela (1926). Surveying the existing literature on the cathedral, Porter writes,

Miss King [in The Way of Saint James], while bringing much new light had her hands far too full with the vast subject of the pilgrimage roads to be able to undertake the thousands of patient measurements, the conscientious checking up of results, the stone-for-stone study of the build ing required for an architectural monograph. ${ }^{10}$

Implicitly, Porter aligns himself with the "patient" and "conscientious" "stone-for-stone study" practiced by his student, Conant-the very approach labeled "mere pedant[ry]" by King. ${ }^{11}$ The self-consciously differing objectives and methods of the art historian as envisioned by King and Porter, then, are readily apparent in their respective writing.

But as distinctive as each medievalist's prose, I suggest, is his or her mobilization of visual evidence. Though King, like Porter, engaged deeply with images and objects, her own production of images and objects-namely, photographs and illustrated scholarly publications - has received less attention. ${ }^{12}$ Here, this topic is addressed through photographs featured by King in The Way of Saint James. I propose that these photographs deserve

8 Georgiana Goddard King, The Way of Saint James, 3 vols. (New York: G.P. Putnam's Sons, 1920), 1:23.

9 Ibid.

10 Arthur Kingsley Porter, "Santiago Again," Art in America and Elsewhere (February 1927): 5-6.

11 Conant wrote a fond review of King's Heart of Spain (1941), a book published two years after her death. In the review, he praises King's "flashing mind, her keen artistic judgment, and her warm appreciative intelligence" and calls her "one of the choicest critics among American critics, historians, and teachers of medieval art." See Conant, "Heart of Spain [review]," The Art Bulletin 24 (1942): 110.

12 There are important exceptions, however. On the topic of King's usage of photography, see Caviness, "Seeking Modernity Through the Romanesque." For more on Porter's usage of photography-better documented than King's, like his career at large-see Christopher R. Lakey, "Contingencies of Display: Benjamin, Photography, and Imagining the Medieval Past," Postmedieval: A Journal of Medieval Cultural Studies 7 (2016): 86-87; Kathryn Brush, "Imag(in)ing Medieval Stones: Arthur Kingsley Porter, Photography, and the Study of Romanesque Sculpture after World War I" (paper presented at "Photo Archives and the Photographic Memory of Art History," Part III, Institute of Fine Arts, New York University, New York City, March 25-6, 2011); Friedrich Kestel, "The Arthur Kingsley Porter Collection of Photography and the European Preservation of Monuments," Visual Resources 9 (1994): 361-381; and James Ackerman, "The Visual Arts Collections: Manifold Resources," in The Invention of Photography and Its Impact on Learning: Photographs from Harvard University and Radcliffe College and from the Collection of Harrison D. Horblit, ed. Louise Todd Ambler and Melissa Banta (Cambridge, MA: Harvard University Library, 1989), 62-71. 
careful consideration as interpretive tools working in tandem with the text around them. Moreover, I believe that they are contrasted productively with photographs featured by Porter in Romanesque Sculpture of the Pilgrimage Roads. For it is through examination of King and Porter's treatment of the same subject, the Camino de Santiago, that differences in their scholarship emerge most starkly. These differences can be observed at once visually and textually: while the photographs included by Porter in Romanesque Sculpture of the Pilgrimage Roads demonstrate his commitment to what he termed "stone-for-stone study," those included by King in The Way of Saint James, by contrast, reveal her stated intention to approximate, in book form, a "very pilgrimage."

To be sure, King and Porter alike were precocious in their early adoption of photography. Both learned to photograph to aid their research, and both included reproductions of photographs by themselves, family, friends, and commercial photographers in their various publications. Nonetheless, photographs included in their monographs on the Camino de Santiago betray fundamentally dissimilar conceptions of the practice of art history - and, I argue, shed light on the reasons for Porter's enduring luster and King's eventual anonymity.

First, though, it merits emphasis that I discuss neither King nor Porter as a photographer. Rather, I focus on King's strategic use of photographic illustrations in The Way of Saint James, and arrive at new insights by comparing her approach toward illustrations with that of Porter in Romanesque Sculpture of the Pilgrimage Roads. In part, my motives are practical: while Porter attributes photographs to himself, to his wife, and to commercial photographers, King, unfortunately, does not specify the source of her photographs and photogravures. ${ }^{13}$ Recent scholarship by Madeline Caviness indicates that many were purchased from commercial photographers. ${ }^{14}$ Given the range of photographic authorship in Porter's volumes and the remaining uncertainty regarding attribution in King's, I do not stress the identity of those behind the camera. Instead, I foreground the rhetorical deployment of photographs as art historical evidence by King-evidence in support of a history of art, perhaps, less familiar to us today than that presented by Porter.

\section{Santiago de Compostela: Two Views of the Puerta de las Platerías}

One of the few sites along the Camino de Santiago documented visually in both King's Way of Saint James and Porter's Romanesque Sculpture of the Pilgrimage Roads is its culmination, the cathedral of Santiago de Compostela. ${ }^{15}$ Santiago emerged as a pilgrimage destination for European Christians in the ninth century, nearly a thousand years after the

\footnotetext{
13 In Romanesque Sculpture of the Pilgrimage Roads, Porter includes photographs attributed to himself ("A.K.P."), to his wife ("L.W.P."), and to professional photographers whose images he purchased. Featured in this paper are photographs Porter attributes to the Barcelona-based photographer Roselló Mas and the Madrid-based photographer J. Roig. See Porter, Romanesque Sculpture of the Pilgrimage Roads (Boston: Marshall Jones Company, 1923), 1:357.
}

14 As Caviness writes in "Seeking Modernity Through the Romanesque," both King and her partner and travel companion, Edith Lowber, were active, accomplished photographers. Even so, most of the photographs featured in The Way of Saint James appear to have been purchased from commercial photographers or engraved after photographs already published, indicates Caviness (19). To further complicate matters, few of the many photographic negatives or prints deposited by King and Lowber at Bryn Mawr College and at the Hispanic Society of America can be decisively attributed to either woman. Caviness, quoting Patrick Lenaghan, curator of photography at the Hispanic Society, suggests that these negatives and prints, some of which went on to appear in King's books, all be labeled "photos from the King-Lowber expeditions." See Caviness, "Seeking Modernity Through the Romanesque," 6.

15 For many historical and contemporary pilgrims, the Camino de Santiago has concluded at the cathedral of Santiago de Compostela. Other pilgrims, however, have continued beyond the cathedral to finisterre, a peninsula on the west coast of Spain whose name comes from the Latin finis terrae, "end of the earth." 
remains of Saint James - an early apostle of Christ, who purportedly preached the gospel in Spain, and was martyred in Jerusalem-were said to have appeared miraculously off the coast of Galicia. ${ }^{16}$ By 896 a modest church containing Saint James' to mb began to attract small numbers of pilgrims. ${ }^{17}$

So began the practice of journeying overland or by sea to the remote northwestern corner of Spain, a practice King calls "hugeous, incredible." 18 Even Porter, a more restrained writer, professes that the "actuality of the pilgrimage, like a cosmic phenomenon, overwhelms with the sense of its force, its inevitability."19 As more recent scholarship has stressed, though, there was nothing "inevitable" about Santiago's rise to the ranks of longstanding Christian pilgrimage destinations like Jerusalem and Rome. The construction of the present cathedral of Santiago de Compostela, begun in 1078 under the lea dership of Alfonso VI, King of Castilla, León, and Galicia, and the local bishop, Diego Peláez, serves as a particularly dramatic example of the promotion of pilgrimage by interested parties. ${ }^{20}$

For scholars of early medieval art and architecture, the cathe dral's southern entrance, the Puerta de las Platerías (Silversmiths' Portal), holds particular interest as it appears to be the structure's only remaining Romanesque façade. ${ }^{21}$ Porter, significantly, includes eighteen

16 For an account of the myth and life of Saint James in relation to the cathedral of Santiago de Compostela, see Kenneth Conant, The Early Architectural History of the Cathedral of Santiago de Compostela (Cambridge: Harvard University Press, 1926), 4. For a contemporary perspective on the cathedral, its origins, and its traditions, see José-Luis Senra, En el principio: Génesis de la Catedral Románica de Santiago de Compostela. Contexto, construcción y programa iconográfico (Santiago de Compostela: Teófilo Edicións, 2014).

17 According to Conant, a new church built around Saint James' tomb was begun under the leadership of King Alfonso III (king of Asturias, León, and Galicia) and Bishop Sisnando Menéndez in 879, completed in 896, and dedicated in 899 (Conant, Cathedral of Santiago de Compostela, 6). More recent scholarship has emphasized the role of eleventh-century bishop Diego Peláez in nurturing the cult of Saint James and conceiving the present cathedral of Santiago de Compostela. See for instance Senra, Génesis de la Catedral Románica de Santiago de Compostela.

18 King, The Way of Saint James, 1:25.

19 Porter, Romanesque Sculpture, 1:171

20 The construction of the cathedral of Santiago de Compostela had firmly established religious, political, and financial motivations. Karen Rose Mathews in "Reading Romanesque Sculpture: the Iconography of the South Portal Sculpture at Santiago de Compostela" (Gesta 39 [2000]: 3-12) addresses the role of local archbishop Diego Gelmírez in commissioning the Puerta de las Platerías and shaping its vision of ecclesiastical might. Mathews situates the construction of this south portal in a moment of tension between Gelmírez, and townspeople and lay leaders. Likewise, Barbara Abou-El-Haj explores the cathedral of Santiago de Compostela as an expression of Gelmírez's political ambitions in "Santiago de Compostela in the Time of Diego Gelmírez," Gesta 36 (1997): 165-179. Additionally, Christabel Watson re-dates significant portions of the western facade and interior-long attributed to a single "Master Mateo" - to the tenure of Gelmírez, expanding his already considerable importance to the early development of the pilgrimage to Santiago. See Watson, "A Reassessment of the Western Parts of the Romanesque Cathedral of Santiago de Compostela," Journal of the Society of Architectural Historians 59 (2000): 505-521.

21 M.F. Hearn writes, "all that remains of three great façade ensembles [at the Cathedral of Santiago de Compostela] is to be found on the south transept façade, known as Puerta de las Platerías" (142). He suggests that the portal has undergone at least six major renovations since the twelfth century, leaving the portal program a "meaningless jumble." M.F. Hearn, Romanesque Sculpture: The Revival of Monumental Stone Sculpture in the Eleventh and Twelfth Centuries (Oxford: Phaidon Press, 1981), 145. Porter also considered the portal a puzzle: "No order is traceable in the composition as a whole. Little statues, big statues, pieces of statues are walled in helter-skelter" (212). He proposed that two major renovations have occurred. See Porter, Romanesque Sculpture, 212. More recently, Claudia Rückert has argued that one discrete sculptural element on the Puerta de las Platerías, the so-called "Woman with the Skull," sheds light on the architectural transformations undergone by this southern portal. According to Rückert, the sculpture originally appeared on the Romanesque northern portal, destroyed in the eighteenth century, and was subsequently integrated into the southern portal. This move, she writes, was one of many reconstructions during the medieval, early modern, and modern periods, leading to the portal's "disturbed appearance." Rückert, "A Reconsideration of the Woman with the Skull on the Puerta de las Platerías of Santiago de Compostela Cathedral," Gesta 51 (2012): 130. 
photographs of the Puerta de las Platerías alone in Romanesque Sculpture of the Pilgrimage Roads. The first plate, captioned Puerta de las Platerías, relief in western buttress. A ferocious lion, depicts its subject in great detail (fig. 2). With its head swiveled to ward the viewer, a sculpted lion strides forward intently along its stone backdrop and casts a menacing glance to the right. The lion's muscled haunches and blocky head project from the façade with force, while the pocked granite makes its hollowed eyes seem wild and its hide mangy.

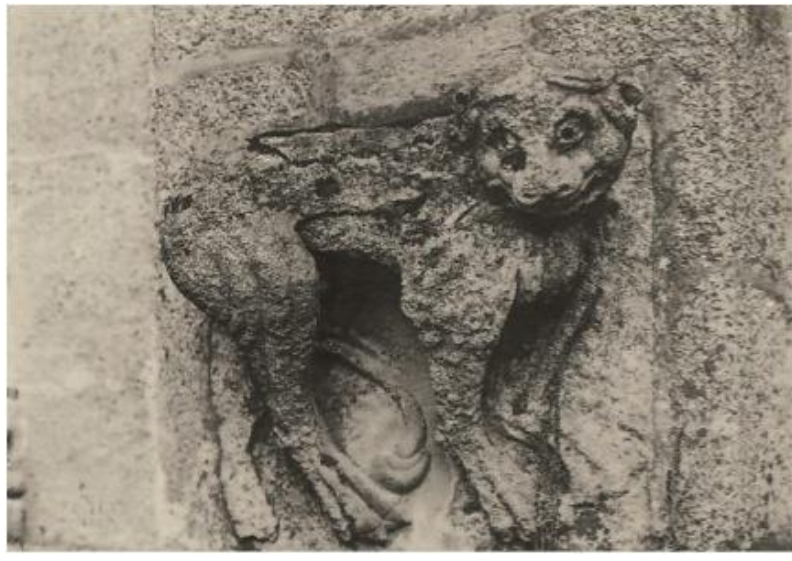

\section{Figure 2}

J. Roig, Puerta de las Platerías, relief in western buttress. A ferocious Lion, from A rthur Kings ley Porter, Romanesque Sculpture of the Pilgrimage Roads, vol.6, Castile, Asturias, Galicia (Boston: Marshall Jones Company, 1923), plate 674 (photo: author).

But in relation to the decorated portion of the façade at large, this beast is marginal, even diminutive. The lion slinks atop a stringcourse to the left of the portal, peripheral to the elaborate figurative sculpture extending across the tympana, spandrel, and jambs (fig. 3 ). Indeed, the photograph itself supplies much of the menace. The tight focus and oblique angle used by the photographer, for example, amplify the lion's size and accentuate its heft. ${ }^{22}$ The creature in $A$ ferocious lion appears ready to pounce out of its frame: its toenails nearly scrape the photograph's lower border, and its back leg, caught mid-stride, flexes with potential. Seen as one component of the larger portal program, however, the lion is less a fearsome predator and more a ready guard.

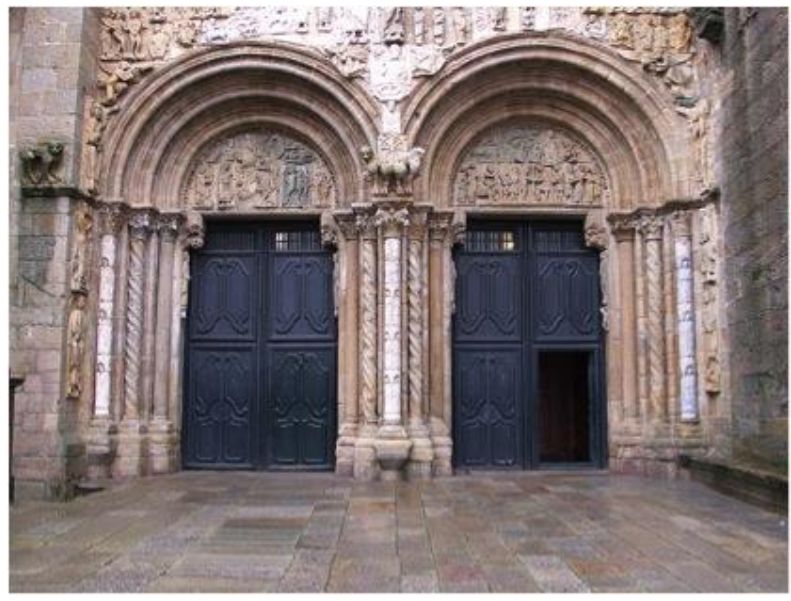

\section{Figure 3}

Cathedral of Santiago de Compostela, La Coruña, Spain, begun c. 1075 , view of the Puerta de las Platerías (photo: José Luis Filpo Cabana, Wikimedia Commons). 
King, in The Way of Saint James, also includes a photograph of the famed Puerta de las Platerías. In her image, titled simply Puerta de las Platerías, Porter's "ferocious lion" becomes an inconspicuous housecat (fig. 4). Far from magnifying a single sculpture, Puerta de las Platerías includes the entirety of the cathedral's southern transept. The photographer captures the full vertical extent of the façade, from the steps leading to the portals, to the first level's portals and spandrel, to the second level's paired windows, and finally to the roofline's balustrade. ${ }^{23}$ The photograph also features a section of the cloister, to the left of the staircase, and the clock tower, to the portal's right. Thus while $A$ ferocious lion portrays a self-contained entity removed from its portal context, Puerta de las Platerías emphasizes the portal's embeddedness in its broader architectural site.

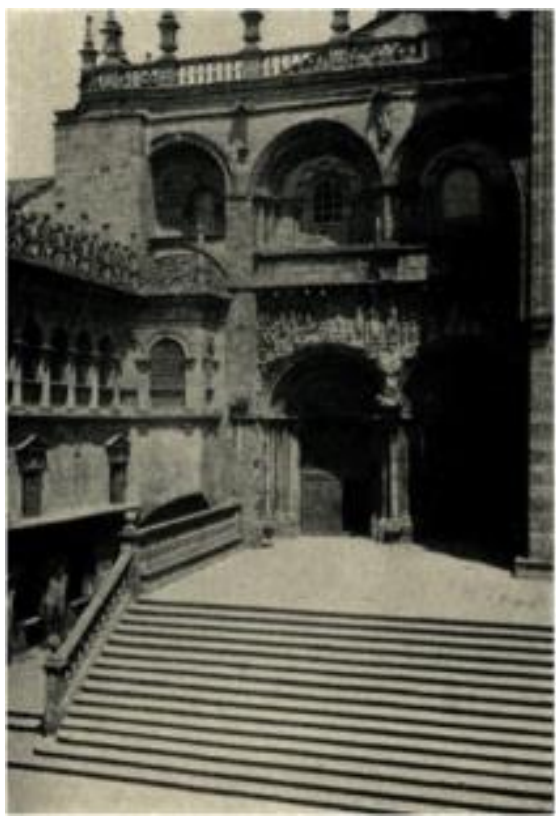

\section{Figure 4}

Unidentified photographer, Puerta de las Platerías, from Georgiana Goddard King, The Way of Saint James, vol. 3 (New York: G.P. Putnam's Sons, 1920), page 145 (photo: author).

In addition to the difference in scale, King's Puerta de las Platerías bears traces of the circumstances behind its making. To the right of the photograph a broad shadow cast by the protruding clock tower sweeps across the cathedral, leaving recessed doorways and windows in varying degrees of darkness according to their depths and distances from the spire. The uneven lighting draws attention to other idiosyncrasies contained within the photograph, from its slightly slanted and plunging perspective to the sole open door in the left portal. Unlike Porter's Ferocious lion, the photograph selected by King prompts consideration of the time and place of its own manufacture.

Already, King and Porter's distinct photographic approaches to the same monument, Puerta de las Platerías, indicate substantial differences in their art historical projects. $A$ ferocious lion, like nearly all of Porter's 1,540 photographs in Romanesque Sculpture of the Pilgrimage Roads, isolates a single sculptural element from its broader programmatic setting (figs. 5 and 6). According to Christopher Lakey, Porter's tendency to ward tightly cropped photographs allowed him to "reproduce aspects of medieval sculpture that would normally

23 As with other photographs and photogravures in The Way of Saint James, King does not credit the photographer of Puerta de las Platerías. 
escape the eyes of modern viewers."24 This approach, he continues, resembles that of Walter Hege and Richard Hamann, German photographers contemporary with Porter who also trained their cameras on medieval sculpture. ${ }^{25}$ Like the photographs of Hege and Hamann, those included by Porter in Romanesque Sculpture of the Pilgrimage Roads demonstrate a high degree of visual precision. Porter, for instance, notes in his text that the Ferocious lion possesses "peculiar paws" and a "sardonic expression," and that its "tail [is] curled a round behind his leg." 26 All of these traits are visible in Porter's photograph but impossible to discern in King's Puerta de las Platerías.

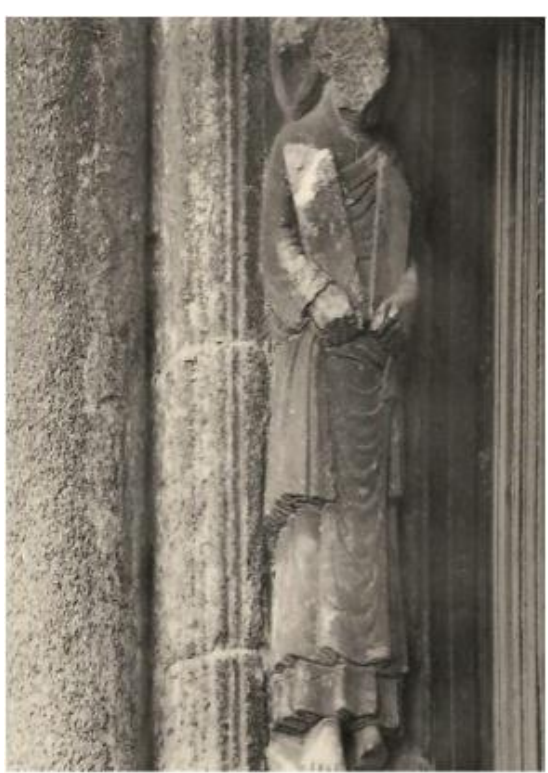

\section{Figure 5}

Lucy Porter, Puerta de las Platerías. Western portal, western jamb. Moses, from A rthur Kingsley Porter, Romanesque Sculpture of the Pilgrimage Roads, vol.6, Castile, Asturias, Galicia (Boston: Marshall Jones Company, 1923), plate 682 (photo: author).

The remaining seventeen of Porter's eighteen photographs of the Puerta de las Platerías in Romanesque Sculpture of the Pilgrimage Roads move carefully across the Cathedral's southern façade. Frame by frame, the images proceed from west to east across the spandrel, then west to east across the tympana, and finally, west to east across the jambs and buttresses. After $A$ ferocious lion, for instance, appears Upper zone, western end. Apostles, St. Peter, Expulsion, Angels (fig. 7). As the title indicates, this photograph encompasses a small portion of the leftmost part of the spandrel. The largest-scale photograph, Puerta de las Platerías, upper portion. Apostles, St. James, Christ, God the Father, Apostles, depicts the central segment of the spandrel (fig. 8). More typically, however, Porter's photographs portray single figures, like A Bishop, or small figural groupings, like Apostles, Angels, St. Peter, an Apostle (figs. 9 and 10).

24 Lakey, "Contingencies of Display," 87.

25 For a critical perspective on Hege's photography, see Markus Hundemer, "Reiter \& Co. -Der Fotograf Walter Hege (18931955) und der Bamberger Dom," in Dem Himmelentgegen: 1000 Jahre Kaiserdom Bamberg exh. cat., ed. Norbert Jung and Wolfgang F. Reddig, 183-192.

26 Porter, Romanesque Sculpture of the Pilgrimage Roads, 1:213. Here, citing their formal similarities, Porter argues that Santiago de Compostela's two lions (one has disappeared, according to Porter [1:213]) were copied some 50 years later by the sculptor who executed the lion of Saint Mark on the papal throne at the Cathédral d'Avignon. 


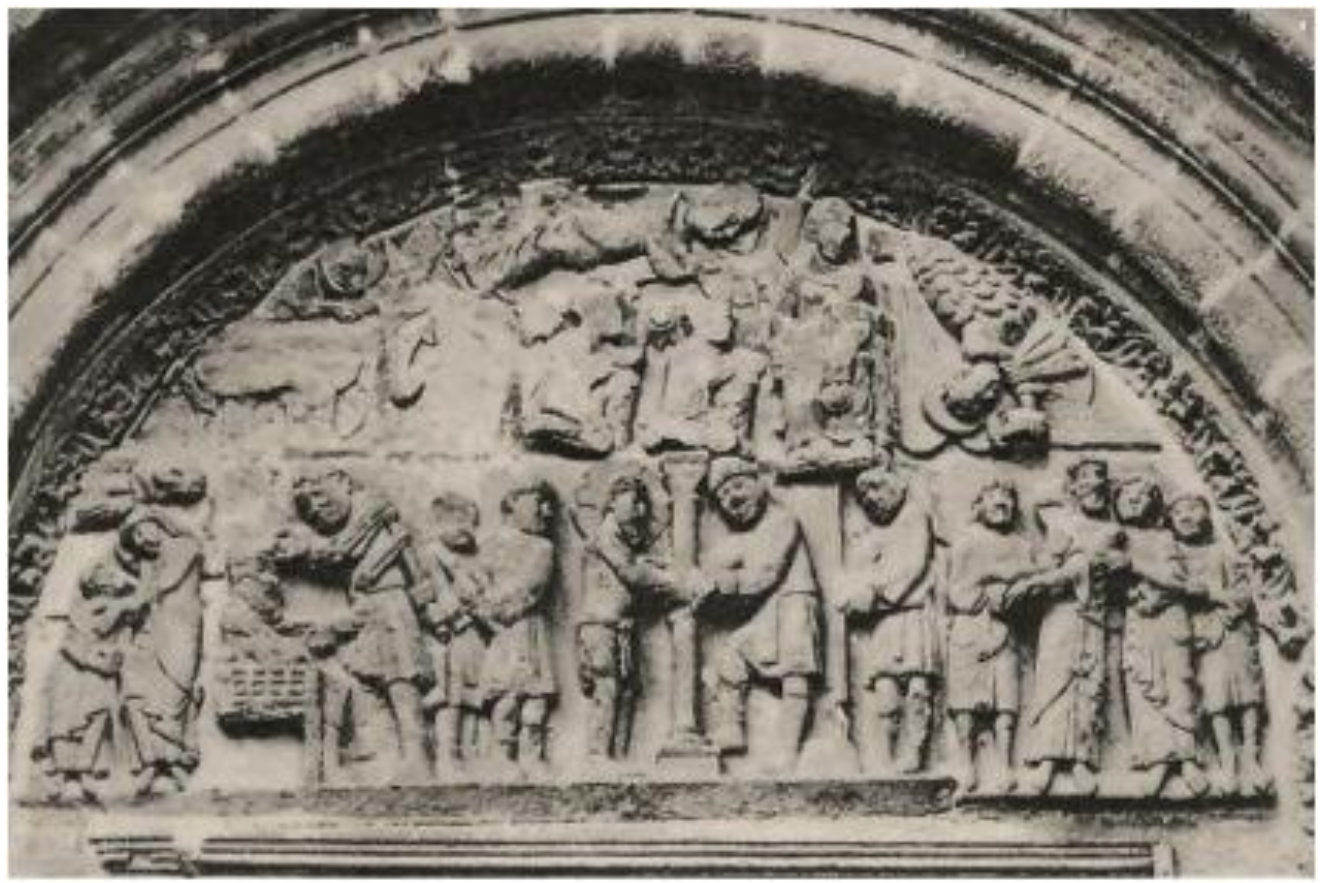

\section{Figure 6}

J. Roig, Puerta de las Platerías. Eastern tympanum. Adoration of the Magi; Doubting Thomas, Crowning with Thorns, Flagellation, Betrayal, from A rthur Kingsley Porter, Romanesque Sculpture of the Pilgrimage Roads, vol. 6, Castile, Asturias, Galicia (Boston: Marshall Jones Company, 1923), plate 680 (photo: author).

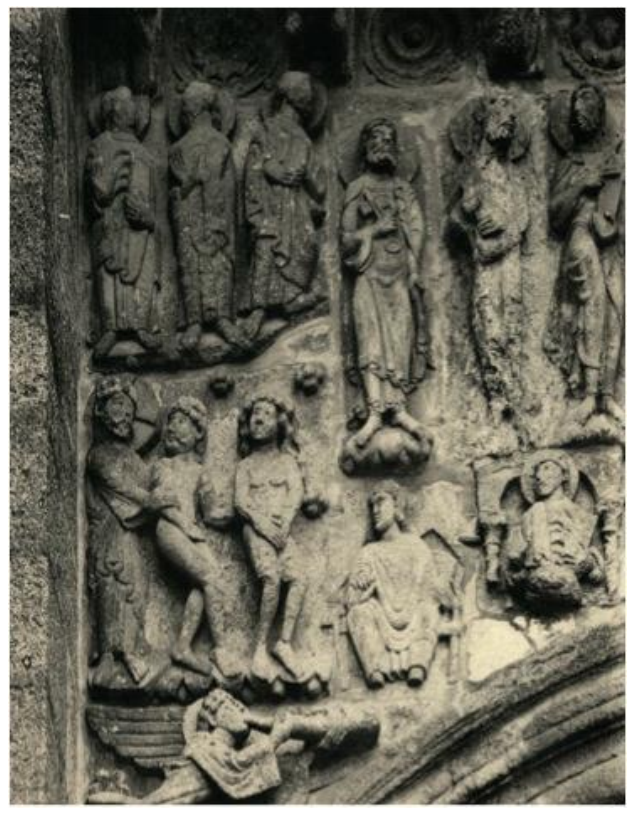

\section{Figure 7}

Lucy Porter, Puerta de las Platerías. Upper zone, western end. Apostles, St. Peter, Expulsion, Angels, from A rthur Kings ley Porter, Romanes que Sculpture of the Pilgrimage Roads, vol. 6, Castile, Asturias, Galicia (Boston: Mars hall Jones Company, 1923), plate 675 (photo: author). 


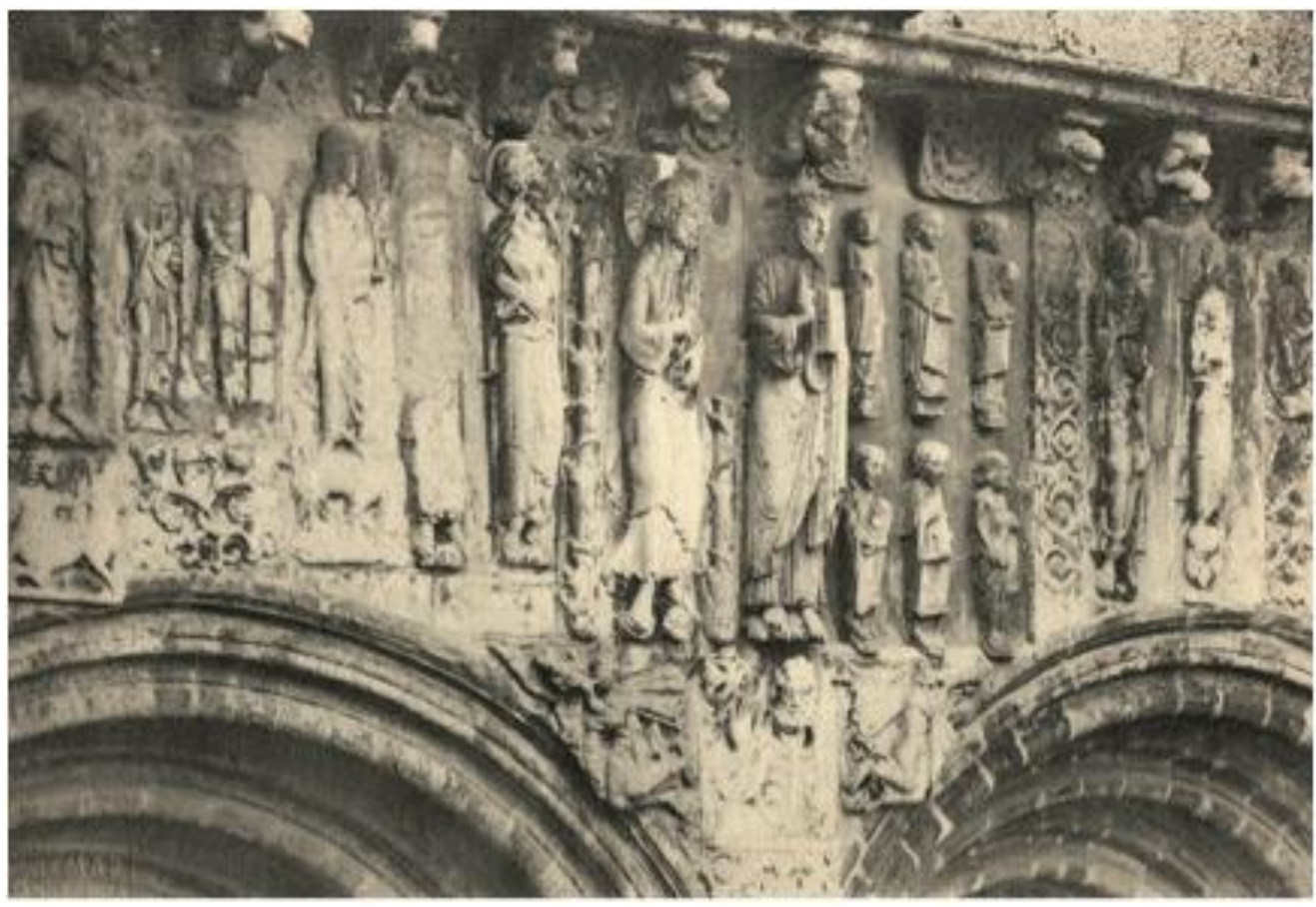

\section{Figure 8}

Roselló Mas, Puerta de las Platerías, upper portion. Apostles, St. James, Christ, God the Father, Apostles , from A rthur Kingsley Porter, Romanesque Sculpture of the Pilgrimage Roads, vol. 6, Castile, Asturias, Galicia (Boston: Mars hall Jones Company, 1923), plate 676 (photo: author).

Here, the mutual dependence of image and text best demonstrates Porter's underlying intent in Romanesque Sculpture of the Pilgrimage Roads. He begins his chapter on the Puerta de las Platerías by noting formal similarities in specific sculptural elements between this portal in Santiago de Compostela and the western portal of Saint-Sernin, in Toulouse. After dismissing the notion that a single "master" executed them both, he notes that "[i]t is, however, evident that one must have influenced the other. Which is the original?"27 In the chapter that follows, Porter places the cathedral of Santiago de Compostela in a spatial and temporal genealogy extending along the Camino, a "chain which stretched from Santiago to the remote ends of Europe. ${ }^{28} \mathrm{He}$ relates the Galician cathedral to developments in sculpture and architecture to be found from Lombardy, in Italy, to Languedoc, in France. But the means by which he does this merit close attention. After posing the question of which cathedral came first, Santiago de Compostela or Saint-Sernin, Porter's next sentence proves equally revealing: "The documents do not determine the question" (emphasis added). ${ }^{29}$ What will, Porter leaves unstated, is the meticulous formal analysis and comparison facilitated by his vast repository of visual evidence-that is, photographs.

27 Porter, Romanesque Sculpture, 1:211.

28 Ibid., $1: 225$.

29 Ibid., 1:211. It should be noted, however, that Porter in fact placed great importance on documentary evidence in dating (see for instance "The Chronological Problem," Romanesque Sculpture, 1:3-17). He simply considered the existing documentary evidence inadequate in the case of the Puerta de las Platerías. 


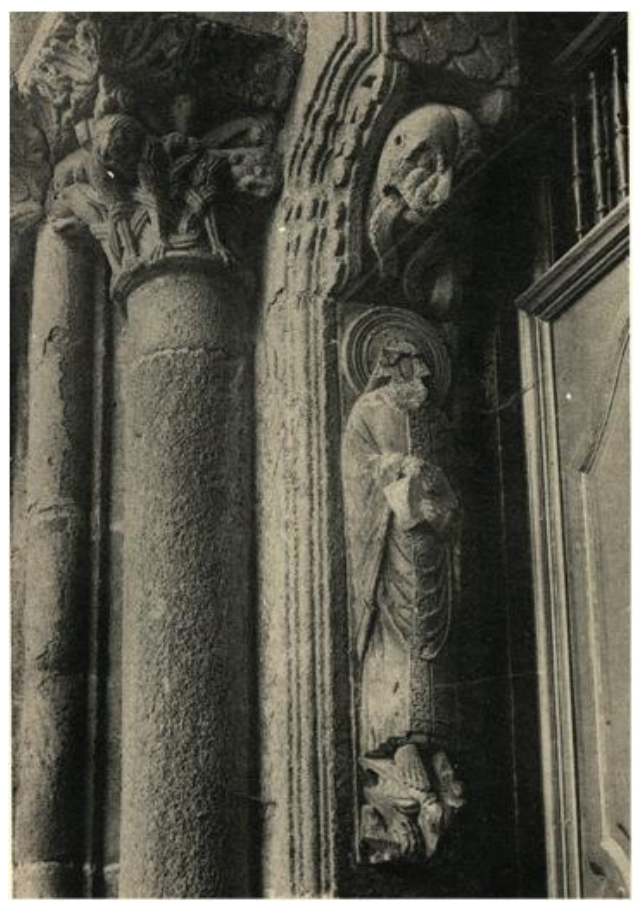

\section{Figure 9}

Roselló Mas, Puerta de las Platería. Eastern portal, western jamb. A Bishop, from A rthur Kingsley Porter, Romanesque Sculpture of the Pilgrimage Roads, vol. 6, Castile, Asturias, Galicia (Boston: Marshall Jones Company, 1923), plate 683 (photo: author).

Porter, in the preface to his earlier book, Medieval Architecture (1909), writes that he has "preferred photographs whenever available as being more accurate and presenting architectural forms as they actually appear." 30 The ratio of plates to text in his scholarship reflects this belief in the "accuracy" of photographs. Medieval Architecture features 1,010 pages of text to 289 plates; in Lombard Architecture, the numbers climb to 1,838 pages of text to 954 plates; and in Romanesque Sculpture of the Pilgrimage Roads, photographs vastly outnumber prose, with 1,540 plates, and 412 pages of text. ${ }^{31}$ This latter book fills ten volumes, one of them devoted exclusively to prose and the other nine, remarkably, dev oted exclusively to full-page photographs.

While the prose and photographs in Romanesque Sculpture of the Pilgrimage Roads appear in distinct volumes, Porter links them tightly by making frequent reference to plates. In his chapter on the Puerta de las Platerías, for instance, Porter notes, "[t]he same extraordinary mixture of subjects exists to-day in the tympana (IIl. 678-680)" directing readers to visual confirmation of the tympana's heterogeneity across three different photographs. ${ }^{32}$ The plates themselves, moreover, feature long titles which systematically locate the sculptures by city, province, monument, and position within the monument. Titles also provide iconographic explication, as in this example from the Puerta de las Platerías: "Santiago de Compostela [city], (La Coruña) [province], Catedral [monument]. Puerta de las Platerías, western jamb [position within monument]. Creation of Adam; God reproves Adam

30 Porter, Medieval Architecture: Its Origins and Development (New York: The Baker and Taylor Company, 1909), viii.

31 For the source of these figures on the ratio between images and text in Porter's scholarship, see Friedrich Kestel, "The Arthur Kingsley Porter Collection of Photography and the European Preservation of Monuments," Visual Resources 9 (1994): 365 .

32 Porter, Romanesque Sculpture, 1:213. Emphasis added. 
and Eve; Angels, Prophets [iconography]."33 Unsurprisingly, just the list of illustrations accompanying Porter's 1,540 photographs fills tens of pages. Porter, to be sure, argues as much through images as words.

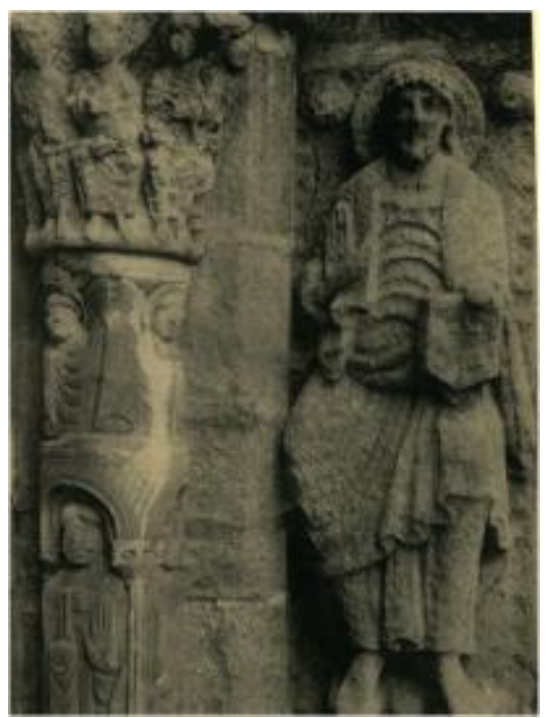

\section{Figure 10}

J. Roig, Apostles, Angels, St. Peter, an Apostle, from A rthur Kingsley Porter, Romanesque Sculpture of the Pilgrimage Roads, vol. 6, Castile, Asturias, Galicia (Boston: Marshall Jones Company, 1923), plate 688 (photo: author).

King, though, displays a different attitude toward photography. She writes in the forward to The Way of Saint James, "Spain is a long way off, and pictures are not always explicit." 34 Certainly, King makes less use of photographs than Porter: The Way of Saint James reverses his ratio of images to prose, with 37 plates and 1,687 pages of text. King, furthermore, embeds photographs into her three volumes. Unlike Porter, she intersperses her text at varying intervals with illustrations - some, full-page photogravures, and others, photographs that share the page with words. Often, these illustrations bear no direct relation to the prose nearest to them, and searching for relevant passages requires considerable page-thumbing. Perhaps most noticeably, while Porter's photographs focus exclusively on sculpture, King includes a much wider array of imagery. Among the subjects of photographs included in The Way of Saint James are mountain ranges, plazas, bridges, markets, and farmers; many photographs, moreover, contain landscape, architectural, and human elements in a single composition (figs. 11 and 12).

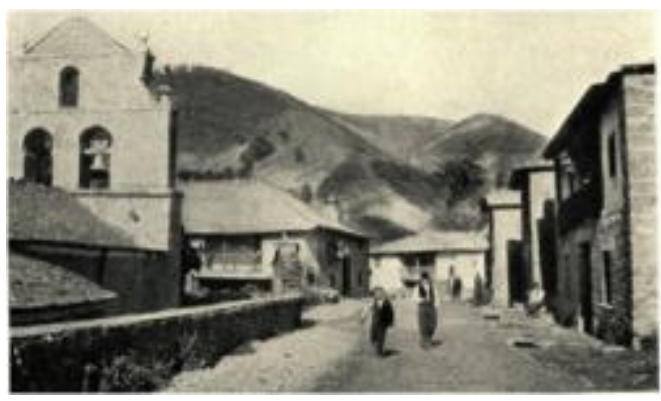

\section{Figure 11}

Unidentified photographer, A Little Town in Leon, from Georgiana Goddard King, The Way of Saint James, vol. 2 (New York: G.P.Putnam's Sons, 1920), page 235 (photo: author).

33 Porter, Romanesque Sculpture, vol. 6, Illustrations: Castile, Asturias, Galicia, 7.

34 King, The Way of Saint James, 1:iii-iv. 


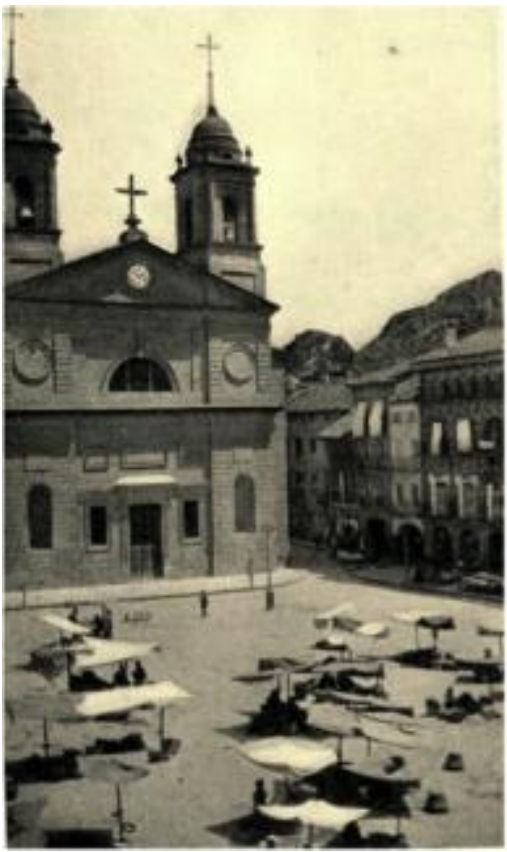

\section{Figure 12}

Unidentified photographer, The Thursday Market in Estella, from Georgiana Goddard King, The Way of Saint James, vol. 1 (New York: G.P. Putnam's Sons, 1920) opposite page 326 (photo: author).

King's photographs in The Way of Saint James number fewer than Porter's in Romanesque Sculpture of the Pilgrimage Roads. They also appear less methodically ordered and titled. Even so, they express her purpose as aptly. Puerta de las Platerías, for instance, permits factors external to the façade to intercede in its representation (fig. 4). Contingencies like shadow, sunlight, and perspective each mark the cathedral's southern entrance, generating speculation as to the photographer's viewpoint, the time of day, the season, and even weather conditions. While this may be true of all photographs, a composition like Ferocious lion purposefully minimizes circumstances beyond its subject. It is these very circumstances, by contrast, from which Puerta de las Platerías derives some of its most significant visual qualities.

In the forward to The Way of Saint James, King rather strikingly states her interest in social, religious, historical, and circumstantial factors external to the works of art and architecture she encounters. There, she directs readers "who desire to secure facts while avoiding the context" to her index. "This makes it possible," she continues, "for the learned to look up a church unmolested by the dust of the highway." 35 But King herself is as interested in the "dust of the highway" as the church. Better put, she is as interested in the church and how "dust" shapes perception of the church-and, for that matter, perception of all else that is to be found along the highway. 
King's recounting of the twelfth-century pilgrimage to Santiago de Compostela by French monk Aimery Picaud exemplifies this interest. ${ }^{36}$ Of particular relevance is a passage in which she interweaves speculation about the physical appearance of the cathedral of Santiago de Compostela in the twelfth century with her imaginative reconstruction of Picaud's experience there:

For him, the crypt has become fabulous: there lies S. James in a marble ark, in a fair vaulted sepulcher, wonderful for size and workmanship; it is lighted heavenly-wise with carbuncles like the gems of the New Jerusalem, and the air is kept sweet with divine odours; waxen tapers with heavenly radiance light it and angelic service cares for it. ${ }^{37}$

As in the photograph Puerta de las Platerías, this passage portrays the site at hand-the crypt below the ground level of the cathedral, with a tomb supposedly containing the remains of Saint James ${ }^{38}$-through layers of sensory apprehension. King's sensitivity to scale, texture, light, and even smell conjure the crypt as a space experienced rather than a purely architectural space. If Puerta de las Platerías evokes a clear, bright morning due to the shadows stretching west across the façade away from the eastern clock tower, this passage, helped by King's liberal use of adjectives like "fabulous," "fair," "sweet," and "divine," casts the scene in a wondrous, deeply felt aura of religious marvel.

King's dedication to conveying experience in The Way of Saint James encompasses individuals with less historical import than Picaud, presumed author of the famed Camino de Santiago guide-book, the Codex Calixtinus. Once in Santiago de Compostela, for instance, King observes a shortage of religious faith. There, she perceives "gravity, but on the whole little devotion." ${ }^{39}$ While her description of the cathedral's crypt as beheld by Picaud bathes the scene in beatitude, lay worshipers in Santiago receive rougher treatment. "At the shrine you see men kneeling a little awe-struck," she says, but, "at the gold, or at the age?" Likewise, she writes, "[y]ou find a group of women saying litanies. But S. James means nothing to them, he is only the means of making magic." 40 This frank ascription of transactional motives to worship-and significantly, the appeal of material opulenceindicates the range of people and the breadth of experience that King considers worthy of study. From pious medieval monks to calculating contemporaries, she extends her thought to both the lofty ideals and complex realities of faith.

Two additional images of Santiago de Compostela in The Way of Saint James, The Fountain at Santiago and A Beggar by the Puerta Santa, make evident King's curiosity,

36 Aimery (or Aymeric) Picaud, a monk and scholar from Poitou, undertook the pilgrimage to Santiago de Compostela around 1140 (though King says, "not later than 1138" [58]). He is credited by historians with authorship and/or editorship of the Codex Calixtinus (occasionally called The Book of Saint James), five volumes on the Camino de Santiago containing liturgies, reports of miracles, and a traveler's guide. See Jan Van Herwaarden, Between Saint James and Erasmus: Studies in Late-Medieval Religious Life (Leiden: Brill, 2003), 356-361. Millán Bravo Lozano also offers a helpful introduction to and contextualization of the Codex Calixtinus in Guía del peregrino medieval. Introducción, traducción, y notas (Sahagún: Centro de Estudios del Camino de Santiago, 1990). For a gripping, recently published work of historical fiction in which Picaud appears, see Lucy Pick, Pilgrimage (New York: Cuidono Press, 2014).

37 King, The Way of Saint James, 3:59.

38 To the question of whether Saint James's remains are actually in the tomb at the cathedral of Santiago de Compostela, Conant answers, "[t]he Middle Ages were much surer that he was than we can be." Conant, Cathedral of Santiago de Compostela, 4.

39 King, The Way of Saint James, 3:23-24.

40 Ibid., $3: 24$ 
empathy, and expansive gaze. In The Fountain, two women gather water at the Fuente de los Caballos (Fountain of the Horses), in the plaza immediately adjacent to the cathedral's Puerta de las Platerías (fig. 13). The women perform a prosaic chore, indifferent to their proximity to one of Christianity's most sacred sites. The woman at the left stands as stout and imperious as her monogrammed, bell-shaped jug, and the younger woman to the right leans against the fountain's lip, concealing what appears to be a grimace with her hand. Curiously, these women recall an earlier description of Santiago's faithful. King, in a passage already quoted, observes "little devotion" in Santiago "except," she continues, "sometimes in the case of women: young women, who are afraid of life and take precautions: or elder ones who have suffered in life, and look for anodyne." ${ }^{41}$ This written sketch is in no way paired formally with The Fountain. Still, its inclusion of another human dimension to faith - adding the alleviation of fear and suffering to the attraction of "gold," "age," and "magic" - seems applicable to these women, one younger and palpably timid, and the other, older and outwardly hardened.

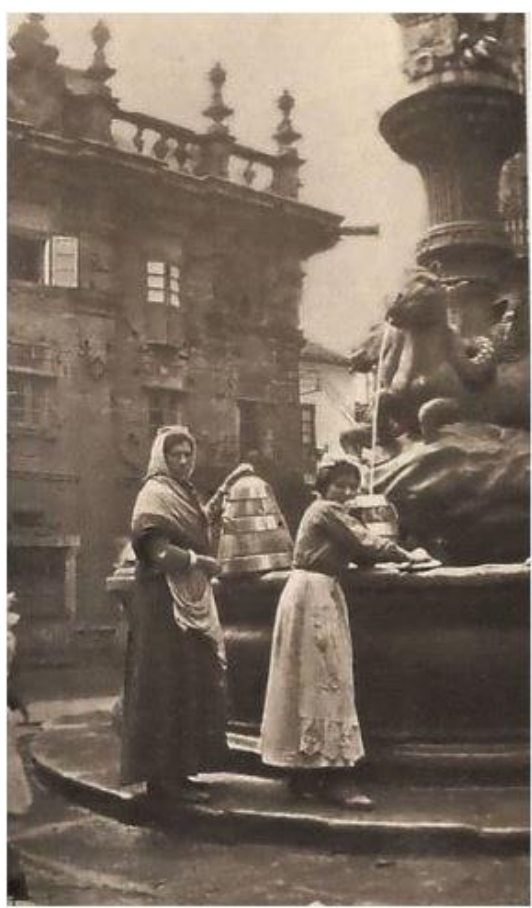

\section{Figure 13}

Unidentified photographer, The Fountain at Santiago, from Georgiana Goddard King, The Way of Saint James, vol. 3 (New York: G.P. Putnam's Sons, 1920), opposite page 54 (photo: author).

In A Beggar by the Puerta Santa, like The Fountain, architecture provides the backdrop to human life (fig. 14). The "beggar" advances along the cathedral's east entrance, which plays a meaningful role in lived ritual at Santiago de Compostela. The Puerta Santa (Holy Door) opens to the public only during Saint James Holy Years; through the portal, the public may enter the rear ambulatory, behind the altar, and descend the staircase leading to Saint James' crypt (fig. 15). ${ }^{42}$ But the left edge of the photograph included by King aligns almost

41 King, The Way of Saint James, 3:24.

42 The Puerta Santa is opened to the public during Años Santos Jacobeos (also called Años Santos Compostelanos), years in which July 25 (Saint James's Day) falls on a Sunday. Miguel Taín Guzmán gives an account of the social history of the Puerta Santa and festivals associated with it in "Arquitecturas festivas catedralicias: los castillos y las fachadas de los fuegos del apóstol Santiago," Ciencias Sociais e Humanidades 22 (2010): 495-518. 
precisely with the right edge of the Puerta Santa. This effectively eliminates the portal from view. In fact, all that is visible of the Puerta Santa in A Beggarby the Puerta Santa is six of the twenty-four sculpted doormen comprising the portal's frame. ${ }^{43}$ The photograph's flat lighting and slanted angle, moreover, cause the sculptures to recede into their alcoves.

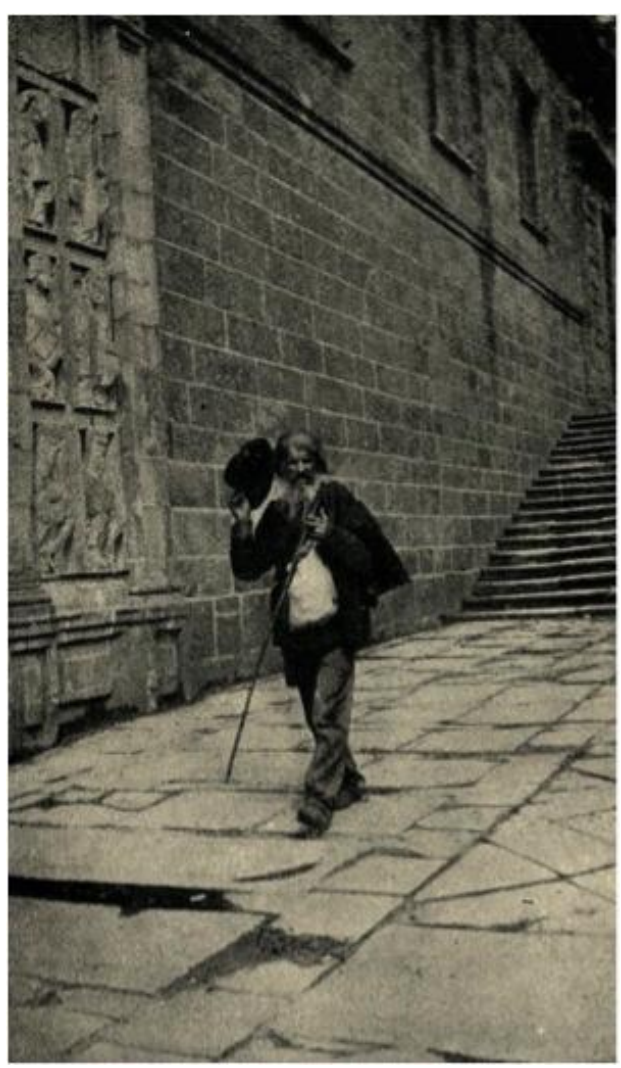

\section{Figure 14}

Unidentified photographer, A Beggar by the Puerta Santa, from Georgiana Goddard King, The Way of Saint James, vol. 3 (New York: G.P.Putnam's Sons, 1920), page 109 (photo: author).

In A Beggar by the Puerta Santa, it is not the famed and titular portal that occupies the most space. Instead, the stone paving of the Plaza de la Quintana and the unarticulated eastern façade of the cathedral loom large. Of course, these elements serve to highlight the photograph's real subject, its "beggar." Not coincidentally, it seems, he bears a striking physical resemblance to the sculpted Saint James who presides over the out-of-frame Puerta Santa (fig. 16). Like the sculpture of Saint James, the passerby has long hair, a staff, and a wide-brimmed hat which he has removed, in apparent acknowledgement of the photographer. Intriguingly, the man grasps his staff just like the nearby sculpture of Saint James: the two fingers closest to his thumb wrap around his walking stick, while the remaining two curl beneath it. A Beggar by the Puerta Santa, with its preference for the human figure over the sculpted figure, typifies King's commitment to portraying experience. Rather than a photograph of the celebrated Puerta Santa and its revered Saint James, she instead chooses to feature a humble pilgrim passing perpendicular to his stone look-alike.

43 Emilia Lamelas and Jesús María Cendán discuss the seventeenth-century Puerta Santa and its sculpted doormen in greater detail in their article on its restoration, "La nueva Puerta Santa, Catedral de Santiago de Compostela," Restauración \& rehabilitación 93 (2004): 58-63. 

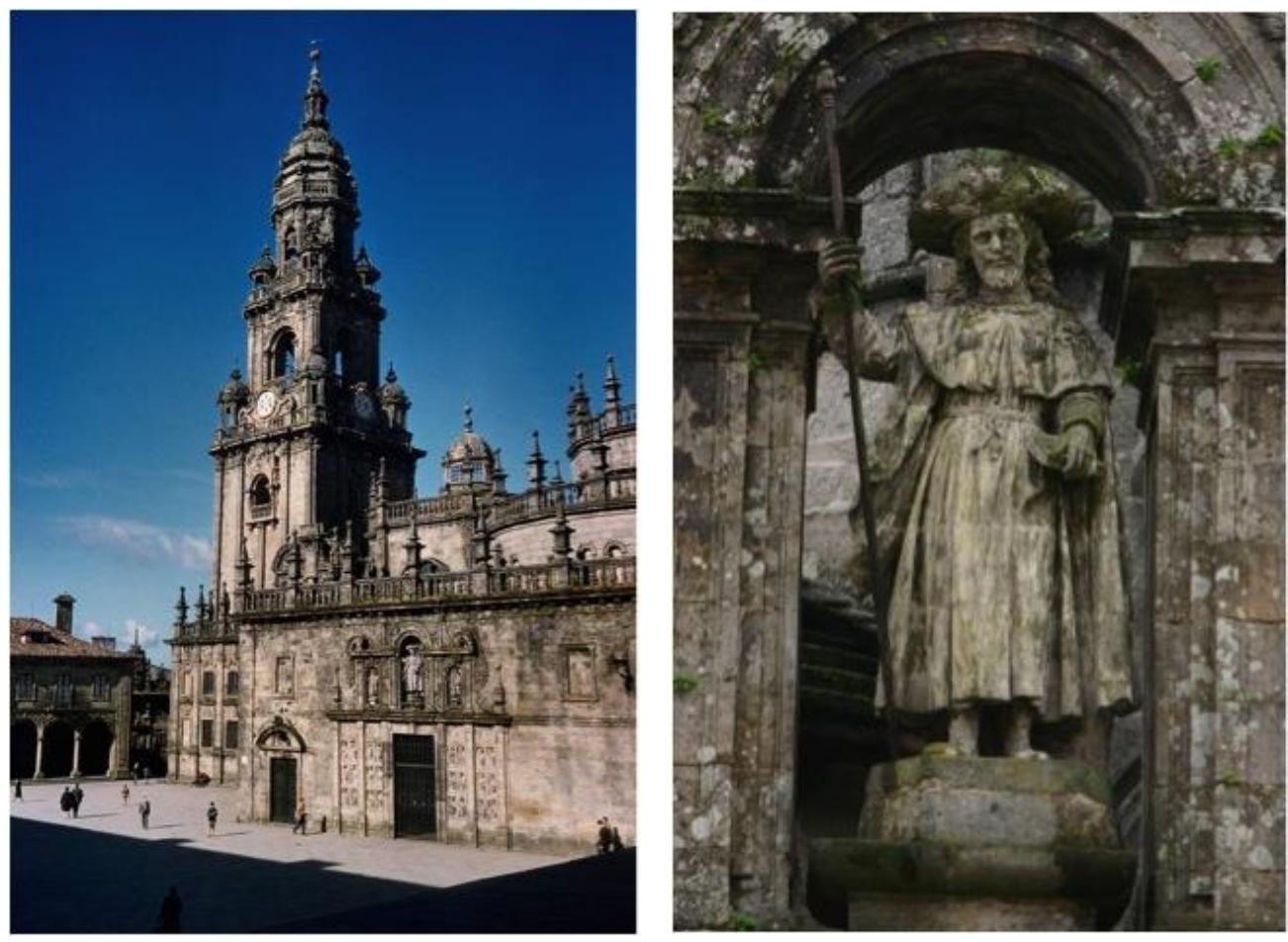

Figure 15

Cathedral of Santiago de Compostela, La C oruña, Spain, begun c. 1075, view of the Puerta Santa (Holy Door) (photo, 1960: William Keighley, ARTstor).

Figure 16

Cathedral of Santiago de Compostela, La C oruña, Spain, begun c. 1075, view of Saint James, Puerta Santa (Holy Door) (photo, 2006: Wikimedia Commons).

\section{King and the "Pilgrim's Perspective"}

In 1913, at Bryn Mawr College, King offered the first graduate course on Spanish art in the United States. ${ }^{44}$ Until her death in 1939, King would teach and publish tirelessly on secular and ecclesiastical medieval art and architecture of the Iberian Peninsula. ${ }^{45}$ For King, the appeal of Iberia lay in the opportunity for discovery: in her assessment, medieval Spain had not yet "become a part of the general scheme of things as Siena." ${ }^{46}$ D es pite her early

44 Saunders, "Georgiana Goddard King," 210.

45 Though King dedicated much of her career to the medieval art and architecture of Spain, her interest turned toward Portugal near the end of her life. At the time of her death, she was working on a manuscript on Portugal that remains unpublished and can be found among her papers at Bryn Mawr's Canaday Special Collections library. See Saunders, "Georgiana Goddard King," 230.

46 Mann, "Georgiana Goddard King," 113. 
contributions to medievalism, however, many historiographies of the field omit King altogether, focusing instead on luminaries like Arthur Kingsley Porter, his French sparring partner Emile Mâle, and his students Kenneth Conant and Walter Muir Whitehill. ${ }^{47}$ According to Janice Mann, one of the few art historians to offer a critical reappraisal of King in the twenty-first century, "King and her work have all but vanished from current scholarly memory." 48

Despite the tendency to attribute King's neglect to gender bias, a different factor appears equally significant. This factor-itself gendered, to be sure-is the early twentieth century conceptualization of art history as an academic discipline distinct from amateur aesthetics and connoisseurship. Porter, though removed from the German formation of a scientific art history, or Kunstwissenschaft, contributed to and benefitted from its inroads in the United States. ${ }^{49}$ Indeed, Kathryn Brush credits Porter's growing interest in artistic attribution, dating, and provenance in the 1920 s to his recent immersion in German scholarship. As she writes, Romanesque Sculpture of the Pilgrimage Roads "needs to be interpreted as the first major American rejoinder, or even rival, to certain established genres of German art history." 50

Porter's relationship to German Kunstwissenschaft was hardly simple or stagnant. Still, the title of the first chapter in Romanesque Sculpture of the Pilgrimage Roads-"The Chronological Problem"-indicates the degree to which his art historical imperatives aligned with those gaining purchase within the academy both stateside and abroad. In his recent survey of the "Modern Origins of Romanesque Sculpture," for instance, Robert Maxwell has demonstrated that the early twentieth-century search for the genesis of medieval sculpture caused many art historians to focus on classification according to date, region, material, and style. ${ }^{51}$ The question Porter asked of the cathedrals of Santiago de Compostela and Saint Sernin-"Which is the original?"-fits comfortably within this paradigm. But King's photographs, as much as her prose, reveal the gulf between her own art historical objectives and methods, and those of her peers and successors.

If King has effectively "vanished" (or, been vanquished) why return to her and her genre-defying book, The Way of Saint James? Madeline Caviness, Janice Mann, and Susanna Terrell Saunders, King's three recent champions in the United States, offer a variety of reasons. For Mann, King's writing provides a barometer of rapid changes within art history in the first half of the twentieth century. As she writes, "[b]y the 1930s the personal grounding

47 Porter and Mâle famously disagreed over the origins of Romanesque sculpture, with Mâle arguing for the primacy of Languedoc and Toulouse, and Porter emphasizing the pilgrimage roads as transnational carriers of artistic and architectural styles. See Porter's review of Mâle's L'art religieux du XII siècle en France (1922), "Spain or Toulouse? And Other Questions," The Art Bulletin 7 (1924): 2-25.

48 Mann, "Georgiana Goddard King," 111. For a historiographic study of Spanish medieval art and architecture that explores the evolution of what Mann terms "current scholarly memory," see John W. Williams, "Spain or Toulouse? A Half Century Later, Observations on the Chronology of Santiago de Compostela," in Actas XXIII Congreso Internacional de Historia del Arte. Granada. 1973 (Granada: Universidad de Granada, 1976), 557-567; and Williams, "The Emergence of Spanish Romanesque Sculpture: A Century of Scholarship," in Current Directions in Eleventh-and Twelfth-Century Sculpture Studies, ed. Robert A. Maxwell and Kirk Ambrose (Turnhout: Brepols, 2010), 188-196.

49 For an account of Porter's attitudes toward developments in German art history, see Brush, "German Kunstwissenschaft and the Practice of Art History in America after World War I. Interrelationships, Exchanges, Contexts," Marburger Jahrbuch für Kunstwissenschaft 26 (1999): 12-14.

50 Brush, "German Kunstwissenschaft," 14.

51 Robert Maxwell, "Modern Origins of Romanesque Sculpture," in A Companion to Medieval Art, ed. Conrad Rudolph (Malden, MA: Blackwell Publishing, 2006), 334-356. 
of much of King's scholarship caused it to lose credibility with the next generation of art historians, whose art historical methods were more regimented and scientific." 52 Saunders strikes a similar note, suggesting that King's "'passionate' attachment to Spanish culture, ironically, tended to restrict the effectiveness of her art historical scholarship. " ${ }^{53}$ Caviness, meanwhile, identifies King's life and work as another example of what she describes elsewhere as the "symbiosis between modern artists and medievalists." ${ }^{54}$ She sees King, and her joint research and photographing expeditions in Spain with Edith Lowber, her partner and travelling companion, as "part of a drive toward modernity.

Crucially, both Caviness and Mann highlight King's forgotten career as a symptom of the status of women within art history and academia at large. For Caviness, King's "is a tale about the silencing of women." ${ }^{56}$ Mann, moreover, stresses that it was King who first sparked Porter's interest in the pilgrimage to Santiago de Compostela. According to Mann, a lecture given by King at Haverford College in 1914 inspired Porter's research for Romanesque Sculpture of the Pilgrimage Roads ${ }^{57}-$ a book, it bears repeating, frequently credited with introducing Anglo-American intellectuals to medieval Spain. This story, and Porter's apparent failure to properly acknowledge King, would seem to confirm Judith Bennett's observations about the conflicted status of women medievalists in her article "Medievalism and Feminism." There, she explains that female scholars achieved earlier and greater acceptance in medieval studies than other fields; even so, she writes, "women have been kept segregated from and subordinated to the mainstream. ${ }^{\prime \prime 8}$

Another reason to revisit King and particularly, The Way of Saint James, looks forward from King's era into the late twentieth and early twenty-first centuries. New directions in Romanesque scholarship suggest that King's writing in fact prefigured many contemporary art historical concerns. Caviness, for one, writes that King's career can be seen not only as part of the "drive toward modernity" but even as "presaging a post-modern breaking down of disciplinary boundaries. " ${ }^{29}$ Certainly, The Way of Saint James-not to mention, King's other books-resist straightforward classification as art history given their historical, literary, archeological, and religious insights. Revealingly, the very eclecticism that troubled severa I of King's critics now seems prescient. Remember that Porter, for instance, felt King "had her hands far too full with the vast subject of the pilgrimage roads to be able to undertake the thousands of patient measurements, the conscientious checking up of results, the stone-forstone study of the building required for an architectural monograph. ${ }^{\prime 60}$ In other words, Porter

52 Mann, "Georgiana Goddard King," 121.

53 Saunders, "Georgiana Goddard King," 231.

54 Caviness, "Broadening the Definitions of 'Art': The Reception of Medieval Works in the Context of Post-Impressionist Movements," in Hermeneutics and Medieval Culture, ed. Patrick J. Gallacher and Helen Damico (Albany, NY: State University of New York Press, 1989), 259-282.

55 Caviness, "Seeking Modernity through the Romanesque," 4.

56 Ibid., 3.

57 Mann observes that Porter discretely credited King with having shown him helpful photographs in "The Development of Sculpture in Lombardy in the Twelfth Century" (1915). See Mann, "Frontiers and Pioneers: American Art Historians Discover Medieval Spain," in Romanesque Architecture and its Sculptural Decoration in Christian Spain (Toronto: University of Toronto Press, 2009), 21.

58 Judith M. Bennett, "Medievalism and Feminism," Speculum 68 (1993): 313.

59 Caviness, "Seeking Modernity through the Romanesque," 4.

60 Porter, "Santiago Again," Art in America 15 (1927): 5-6. 
felt that King's broad, interdisciplinary exploration of the Camino de Santiago hindered her ability to undertake serious art historical research and to produce sound art historical scholarship. Now, King's writing appears newly relevant, and even complementary to that of Porter.

As remarkable as King's precocious transgression of disciplinary boundaries, though, is her attentiveness to both historical and contemporary beggars, worshipers, and pilgrims. Paula Gerson, in "Art and Pilgrimage: Mapping the Way" (2006), writes that early art historical scholarship centered along medieval pilgrimage routes long focused exclusively upon images, objects, and buildings. More recently, however, scholars have moved away from the description, classification, and morphological designation of these works. Now, of greater interest is how residents and visitors have perceived them. "Rather than imposing an artificial model on monuments," she summarizes, "today's scholars prefer to understand pilgrimage from the pilgrim's point of view."61 Likewise, for Christopher Lakey, "A comprehension of a medieval 'way of seeing' is probably more important now than ever before." 62 King, of course, trained her eye and her pen on medieval and contemporary experience. She readily adopted a "pilgrim's point of view," although this distanced her scholarship from what Lakey terms the "art historical 'way of seeing" ${ }^{\prime \prime 63}$ then gaining traction among her colleagues.

King considered individual experience a valid, even essential, line of art historical inquiry. Her dedication to experience-past and present, her own and others' - is evident throughout the three volumes of The Way of Saint James. ${ }^{64}$ Indeed, both Mann and Saunders have observed King's "personal grounding" (Mann's term) and "'passionate' attachment" (Saunders' term) in her writing on the Camino de Santiago. But King's photographs, it should be noted, expose these traits just as readily.

This is particularly evident in King's approach to a carved capital in the cloister of San Pedro de la Rúa, in the Camino town of Estella. Here, text and image prove complementary, with prose offering a straightforward iconographic reading of the capital, and the photograph supplying a jolt of subjective authenticity. From King's verbal descriptions of the historiated capitals, the one photographed can be identified as the Entombment of Christ. Capital at Estella would seem to offer an uncomplicated view of this sculpture, characterized succinctly by King as depicting a "carved sarcophagus, set high on four legs" (fig. 17). ${ }^{65}$

Closer inspection of Capital at Estella, though, reveals a more personal approach. The sarcophagus itself and the sculpted figures beside and above it are actually difficult to discern: rather than a level, tightly cropped view of the sculpture-as Porter likely would have supplied-the photographer replicates the familiar view that results from looking upward at a capital. Because of the tipped-back perspective, other elements feature in the composition-a sliver of the arcade's ceiling, the underside of its rounded stone arch, the

61 Paula Gerson, "Art and Pilgrimage: Mapping the Way," in Rudolph, A Companion to Medieval Art, 610.

62 Lakey, "Contingencies of Display," 89.

63 Ibid.

64 King shared her interest in experience, perception, and consciousness with phenomenologists such as Edmund Husserl, Martin Heidegger, Maurice Merleau-Ponty, and Jean-Paul Sartre. Unfortunately, I have found no concrete evidence that King followed the development of phenomenological thought in the early twentieth century. Still, given King's postgraduate coursework in philosophy, research into her awareness of phenomenology and other philosophical currents would no doubt improve our understanding of her art historical scholarship.

65 King, The Way of Saint James, 1:341. 
neighboring capital, and treetops in the courtyard. Though it fails to provide a clear image of the sculpture in question, Capital at Estella captures something else: the point of view of the photographer, and likewise, those who have craned their necks in a cloister. The effect, it goes without saying, is quite different from Porter's desire to facilitate what Lakey terms an "art historical 'way of seeing"' rather than a "medieval 'way of seeing.' "'66

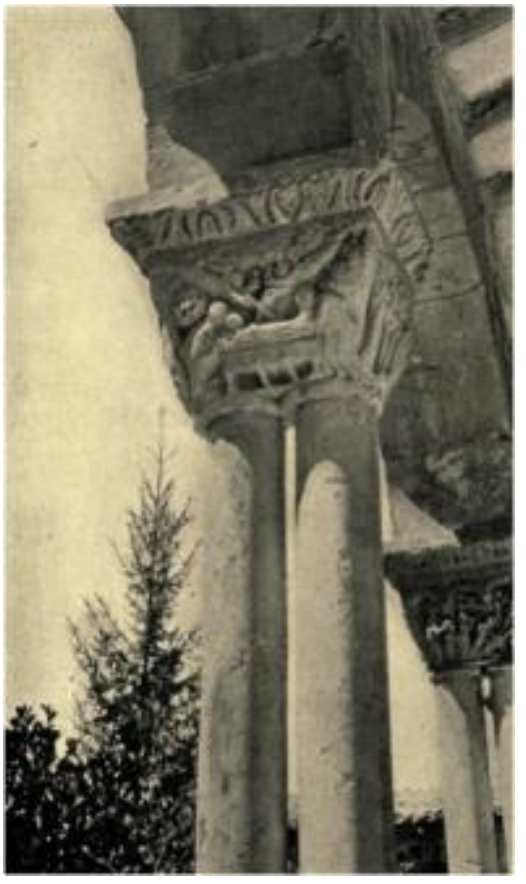

\section{Figure 17}

Unidentified photographer, Capital at Estella, from Georgiana Goddard King, The Way of Saint James, vol. 1 (New York: G.P.Putnam's Sons, 1920), page 349 (photo: author).

King, unlike Porter, considered herself a pilgrim and wrote transparently about the sensory layers between her and the monuments she encountered. Often, these layers are unpleasant: King openly admits to experiencing the fatigue, hunger, boredom, and general discomfort of pilgrimage. In one passage, she describes the tedious landscape approaching León: "The tawny upland is dotted with brown church towers all just alike: you look up after an hour and think you are come back in a circle." ${ }^{67}$ Few art historians would admit the occasional repetitiveness of their research, but for King, this imbues the eventual "spires of Leon" with an "unguessed grace, a charm, a spell of the exquisite." 68 Put another way, it is passing through the unrelieved Castilian plains that makes sight of León's cathedral feel like deliverance.

Elsewhere, King directly addresses the loneliness of solitary research, particularly for women. Of winter nights in Pamplona, home to the raucous running of the bulls during summertime sanfermines, King says:

For a wo man alone, they are hard. She has been out seeing things while the daylight lasted and is honestly tired; moreover, most churches close at nightfall

66 Lakey, "Contingencies of Display," 89.

67 King, The Way of Saint James, 2:176.

68 Ibid., 2:177. 
and the rest have nothing by any chance worth seeing even were they not wrapped in a midnight of their own, just starred with votive candles. ${ }^{69}$

Photographs like Eunate and El Sepulcro evoke the intermittent solitude and melancholy along the Camino de Santiago (figs. 18 and 19). In El Sepulcro, a cluster of children and birds gather at the east end of a church in Torres. While they are not the focus of the photograph, they are impossible to overlook. King's description of her visit to the church expresses similar ambivalence. An earlier art historian had warned King about the children in Torres and their tendency to interrupt work; she writes, somewh at unkindly, "[t] hey are indeed tiresome as gnats, but not bad-hearted . . . their elders rebuked and dispersed them a dozen times, but always they gathered again, filling the open doorway of the empty church, and blotting out the patch of sunlight on the floor." 70 For King, with her mea suring tape and camera, the children and their antics prove a nuisance. Still, the chosen photograph creates a subtle layering of human lives against a church that King goes on to characterize as layered itself, with Greek, Roman, Romanesque, and "Oriental" sources, and French, Italian, and Mudéjar craftsmanship, all "gathered up by the side of the Way."71

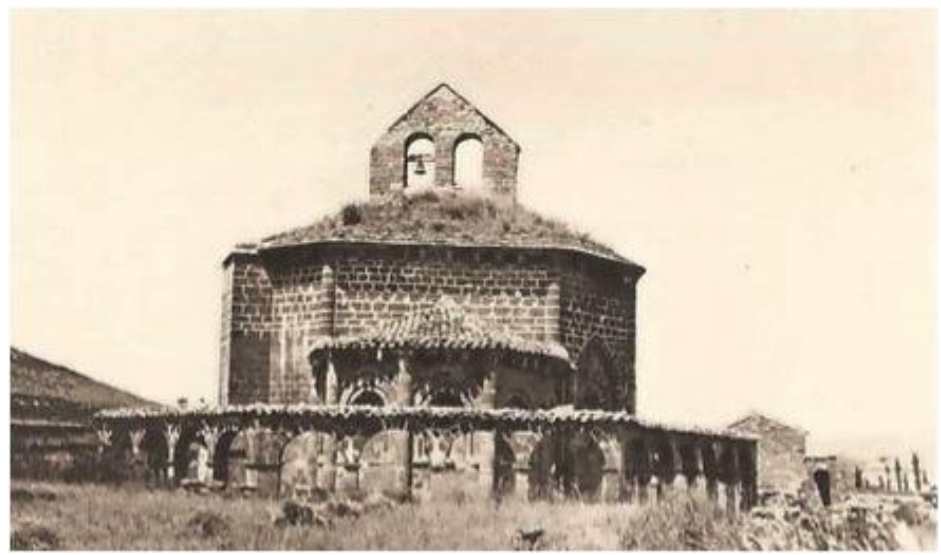

\section{Figure 18}

Unidentified photographer, Eunate, from Georgiana Goddard King, The Way of Saint James, vol. 1 (New York: G.P. Putnam's Sons, 1920), opposite page 230 (photo: author).

A photograph taken in front of the cathedral of Santiago de Compostela's Puerta de Ias Platerías encompasses the emphasis on experience, the pilgrim's perspective, and the self reflexivity characteristic of The Way of Saint James. The Pilgrim in Santiago stands before the Platerías portal, but with the photographer shooting away from the portal and toward the Fuente de los Caballos at the base of the steps (fig. 20). The photograph's rightward tilt echoes that of the pilgrim: the slight inclination of his body suggests the incessant push forward of the Camino, albeit come to an end in Santiago de Compostela. As one might expect, King reveals that his traditional dress inspired the photograph. The pilgrim wears a dark robe studded with scallop shells, the symbol associated with Saint James and the Camino de Santiago, and he bears its customary accessories, the wide-brimmed hat and staff. Struck by the similarity of the man's appearance to Saint Francis, King writes, she

69 King, The Way of Saint James, 1:261.

70 Ibid., $1: 310$.

71 Ibid., 1:321. "Mudéjar" refers to architecture influenced by the Moorish settlement of Spain. King's Mudéjar (1927) focuses exclusively on the significance of North African, Middle Eastern, and Central Asian style and craftsmanship to medieval and early modern Spanish architecture. 
requested a portrait. He "readily yielded; then asked an alms. Why not? Give and take is fair." 72

Throughout The Way of Saint James, King strives verbally and visually to access different perceptions of the same monuments and traditions along the Camino de Santiago. Nonetheless, she tacitly acknowledges that she will be the one to relay these perceptions through prose and photographs. Indeed, in images like A Pilgrim in Santiago, the specificity of individual experience becomes manifest: King's photo-op is another man's charity-op, and her medieval reverie comes to an abrupt halt with their monetary exchange. Time and again, King maneuvers between her commitment to portraying experience and her recognition that any experience aside from her own, whether medieval or contemporary, remains to some degree unattainable. As The Way of Saint James makes plain, this too is part of the "give and take" of art historical writing-a give and take, King would be gratified to learn, ever more important to students and scholars today.
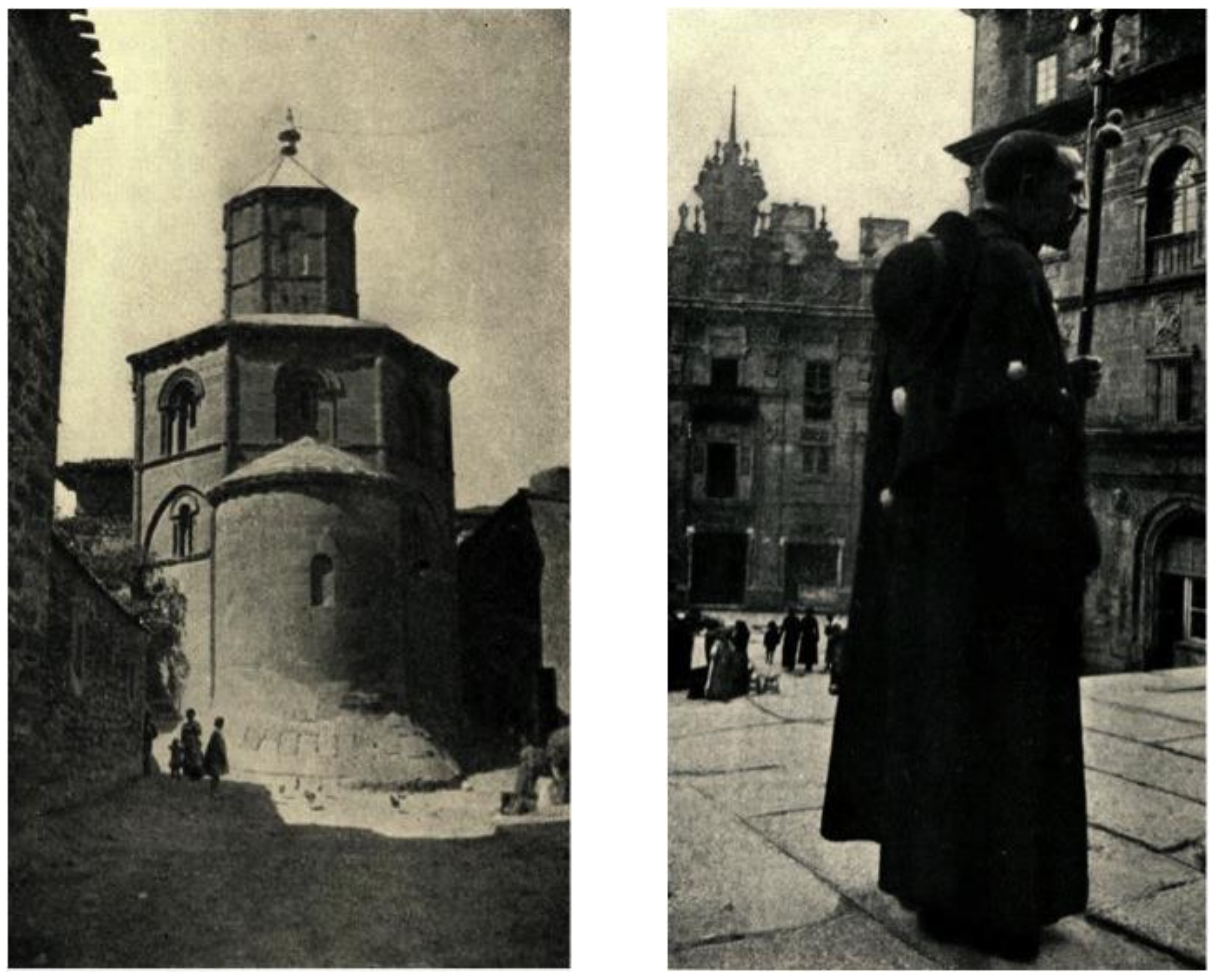

Figure 19

Unidentified photographer, El Sepulcro, from Georgiana Goddard King, The Way of Saint James, vol. 1 (New York: G.P. Putnam's Sons, 1920), page 311 (photo: author).

Figure 20

Unidentified photographer, A Pilgrim at Santiago, from Georgiana Goddard King, The Way of Saint James vol. 2 (New York: G.P. Putnam's Sons, 1920), page 483 (photo: author). 


\section{Acknowledgements}

For early guidance on this paper, I would like to thank Peter Low at Williams College. Paul Park and my peers in his writing seminar at Williams read early versions of this paper and their comments greatly improved it. I am especially grateful to my anonymous peer reviewers, and to my editors at Contemporaneity, Jacqueline Lombard and Elizabeth Morrissey, for their encouragement and suggestions. Lastly, I extend my gratitude to Marianne Hansen at Bryn Mawr College's Special Collections for helping me navigate Georgiana Goddard King's papers and providing me with her portrait. 
$(\mathrm{cc})$ BY

New articles in this journal are licensed under a Creative Commons Attribution 4.0 United States License.

\section{UILIS D-Surle}

This journal is operated by the $U$ niversity Library System of the $U$ niversity of Pittsburgh as part of its D-Scribe Digital Publishing Program, and is co-sponsored by the University of Pittsburgh Press. 

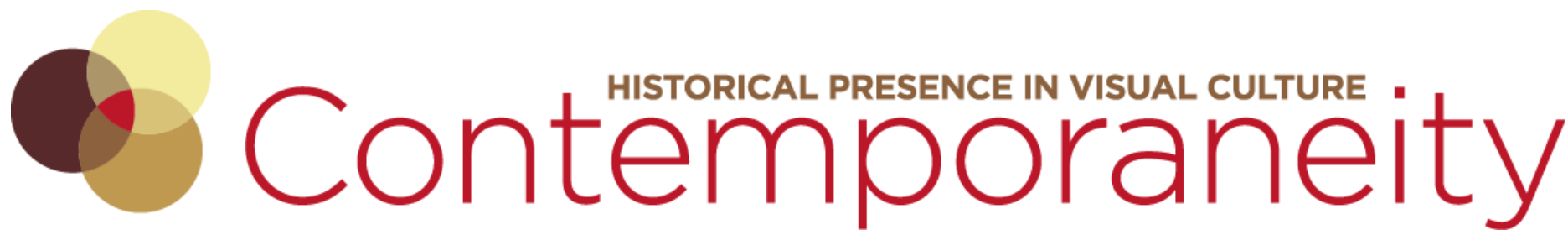

Vol 5, No 1 "Agency in Motion" (2016) | ISSN 2155-1162 (online) | DOI

\title{
Documenting the Invisible
}

Political Agency in Trevor Paglen's Limit

Telephotography

Gary Kafer

\begin{abstract}
Taken from up to forty miles away, Trevor Paglen's limit telephotography ima ges of covert military bases in the American Southwest are blurred by dense atmopshere, dust and debris. In effect, his photographs are highly illegible, and thus the military bases escape any sort of revelation. Following this logic, if one cannot see these top secret locations, then these images are in fact not politically effective at disclosing confidential federal information. Rather, Paglen asserts that the political agency of his can be located not in the image, but in the practice of performing limit telephotography -standing on public land and excercising the right to photograph. In turn, Paglen relocates the documentarian potential of his images into an agency formulated by a relational aesthetic, one in which the communal effects of creating the image and interpreting it generate the possibilities of enacting further practices of political resistance.
\end{abstract}

\begin{abstract}
About the Author
Gary Kafer is PhD student in the Department of Cinema and Media Studies at the University of Chicago, where he received his MA in 2015. His research examines issues of surveillance art practices in our post-privacy culture, as well as questions surrounding digital media aesthetics and contemporary visuality. He graduated Phi Beta Kappa from the University of Pennsylvania in 2014 with a BA in Cinema Studies and Visual Studies, wherein he concentrated in visual neuroscience and perceptual psychology. His honors BA thesis examined Stan Brakhage's plastic montage by using models of motion perception to understand how he generates a type of cinematic illusionism.
\end{abstract}




\section{Documenting the Invisible}

\section{Political Agency in Trevor Paglen's Limit Telephotography}

Gary Kafer

"There are known knowns; there are things we know we know. We also know there are known unknowns; that is to say we know there are things we do not know. But there are also unknown unknowns-the ones we don't know we don't know.

Donald Rumsfeld ${ }^{1}$

More often than not, there is nothing to see in Trevor Paglen's Limit Telephotography series, photographs which attempt to document the "black sites" of the United States militaryindustrial complex. Top secret and highly confidential military bases far removed from populated areas, such black sites are typically buried deep in the extreme recesses of the American southwest, and thus inaccessible and indiscernible to the naked eye and even state-of-the-art cameras. Manipulating technology conventionally used for photographing astrological phenomena, Paglen developed a unique lens system to capture these black sites by mounting his standard-issue Canon digital SLR with telescope lenses ranging in focal length from 1,300 mm to 7,000 mm.2 Armed with this image-making apparatus, Paglen is able to capture subjects at incredibly long distances, usually up to sixty-five miles away. There is, however, an inverse relationship between distance and clarity: using increa singly powerful equipment to see further and further magnifies and distorts large spans of air, dust, and smog that linger in the humid atmosphere. Such optical interference renders his photographs blurry and nondescript, thus precluding full study of the targeted military bases. Yet, at times Paglen's work is surprisingly detailed; small jets, hangar bays, and reaper drones appear palpably close, as men can be seen dismounting planes holding cell phones to their ears and briefcases to their sides. However, most other photographs are far more unintelligible, merely depicting blurred shapes of architectural structures and vehicles disappearing beneath a haze of atmospheric and desert debris.

In his own writing, Paglen argues that rather than documenting military bases, his artistic practice in fact attempts to document the limitations of using photography for revealing hidden truths in federal and military confidentiality. Insisting on this point, Paglen remarks, "[m]y images are not produced in order to be evidence of some kind, or to reveal any kind of information at all. These are art photos." 3 Here, Paglen expresses a certain anxiety over the limitation of using images to produce knowledge about classified federal information. Instead of claiming that his photographs can in fact operate as evidence in his documentary practice, Paglen seems to suggest that limit-telephotography does not document military sites, but rather epistemic boundaries.

\footnotetext{
${ }^{1}$ Infamous statement given by the Secretary of Defense Donald Rums feld in response to a question about the lack of evidence linking the I raqi government with weapons of mass destruction at the Department of Defense news briefing in February 2002. Donald Rumsfeld, "Department of Defense Briefing," (Press Conference, White House, February 12, 2002), C -SPAN, http://www.c-span.org/video/?1686461 /defense-department-briefing.

${ }^{2}$ A typical telephoto lens for this camera model has a focal length of about $300 \mathrm{~mm}$.

${ }^{3}$ Mark Pritchard, "Trevor Paglen Reveals the 'Blank Spots on the Map'," The Rumpus, A pril 7, 2009, http://therumpus .net/2009/04/trevor-paglen-reveals-the-blank-spots-on-the-map/.
} 
One might question, then, the possibilities for political agency in Paglen's documentation, and whether or not it is belied by the representational limits of his image making practice. If one cannot legibly read the spaces that Paglen attempts to document in his work, are these photographs in fact resistive, in the sense that they might expose topsecret military operations? Further, even if one is able to detect such bases and hangar bays in his photographs, are these images revealing any information that might jeopardize such federal activities? And perhaps more generally, is it the case that rather than contributing to his political agenda, Paglen's aesthetic register in fact neutralizes it?

However, such questions narrow the agential possibilities in Paglen's work by reinforcing the binary between aesthetics and evidence in the documentary traditionnamely, that highly aestheticized objects have difficulty serving as forms of evidence. Rather, Paglen remarks that it is his practice of limit-telephotography that constitutes a form of resistance: "I have always conceived of this photography in terms of performance. The act of taking a photograph of a black site is just as important, if not more, than the photograph itself. To take a photograph is to insist on the right to photograph." 4 Paglen thus not only locates the political agency of his limit-telephotography in the images, but also in their production. Here, the process of creating his work, from collaborating with amateur astronomers to turning his camera on classified terrain, becomes inflected with a political intonation. By emphasizing the practice of limit-telephotography, it may be possible to conceive of a model of resistance that operates through a visual aesthetic, as well as a relational one.

In order to advance this claim, I will consider the potential for limit-telephotography to mobilize resistive agency through conversations around the politics of relational art practices between Nicolas Bourriaud and Jacques Rancière. At the intersection of the two, attention will be given to the ways in which the dialectics of political demonstration can be understood as a spatial discourse, which for Paglen registers his work as an "experimental geography." 5 Such a practice rearticulates the documentation of material space along alternative perceptual systems, while also gesturing to a spatial understanding of knowledge production. In this way, Paglen's Limit Telephotography series attempts to understand how political effects can be located at the site of production, rather than purely in the image. At the same time, as a relational aesthetic, limit-telephotography reconsiders how documentation can contribute to political agency at the site of encounter with the image. Understanding how collaborative art practice can function as a form of documentation relieves the image from political responsibility, and gestures outwards to the ways in which limit-telephotography can mobilize different processes of civic engagement against the black world.

\section{The Black World: Democracy, Visibility, and Secrecy}

Targeting confidential military facilities, Paglen's limit-telephotography emerges with in a set of concerted discourses crystallized upon the power and violence of secrecy in the federal system. In her introductory essay to Paglen's photographic monograph Invisible: Covert Operations and Classified Landscapes, Rebecca Solnit observes how Paglen

\footnotetext{
${ }^{4}$ Trevor Paglen, "The Expeditions: Landscape as Performance," TDR: The Drama Review 55, no. 2 (2011): 3 .

5 Trevor Paglen, "Experimental Geography: From Cultural Production to the Production of Space," Experimental Geography: Radical Approaches to Landscape, Cartography, and Urbanism, ed. Nato Thompson and Independent C urators International (Brooklyn, NY: Melville House Publishing, 2008 ), 31.
} 
interrogates the precarious necessity for invisibility within democratic regimes, particularly as a defense mechanism, or "shield, " for military procedures. ${ }^{6}$ Not only does invisibility preve nt outsider access to top-secret information, thus rendering foreign organizations unable to predict actions and plan counterattacks, but it also protects such classified knowledge, placing it beyond the scope of popular criticism and dissent. Invisibility and secrecy then, as Solnit concludes, are not only a "strategy or a mode of operation for the military and the CIA for the past six decades; they have been its essence."

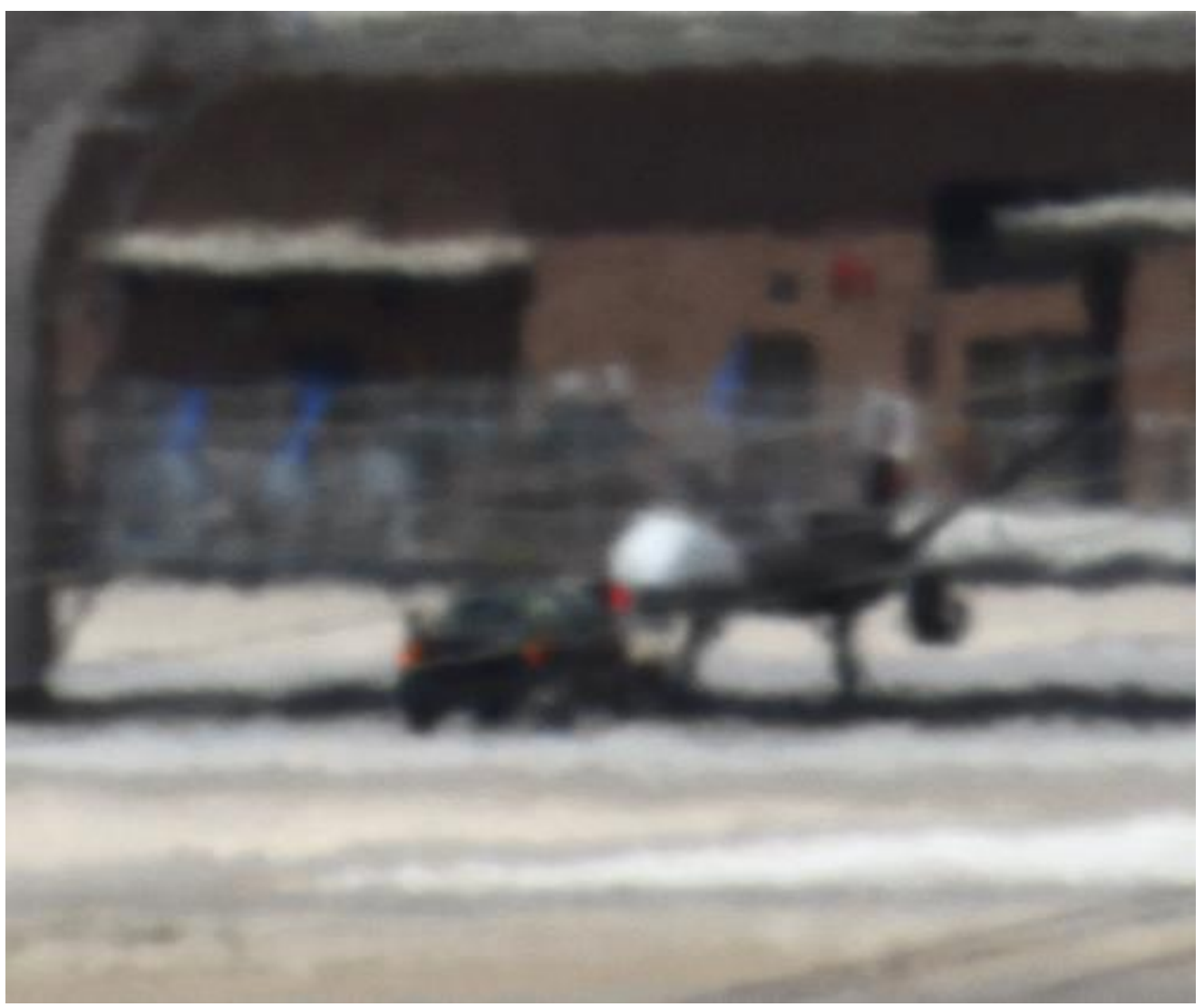

\section{Figure 1}

Trevor Paglen, Reaper Drone (Indian Springs, NV, Distance 2 miles), from the Limit Telephotography series, 2010 . C -print, $30 \times 36$ in. Copyright Trevor Paglen, courtesy the artist and Metro Pictures, New York; A Itman Siegel, San Francisco.

\footnotetext{
${ }^{6}$ Rebecca Solnit, "The Invisibility Wars," in Invisible: Covert Operations and Classified Landscapes, ed. Trevor Paglen (New York: A perture, 2010), 10. Invisible not only explores Paglen's limit telephotography, but also his work tracking top secret satellites (The Other Night Sky series), manipulating the passports and alias es of CIA operatives, and collecting uniform patches affiliated with classified military programs and intelligence-industry activities (Symbology series).

${ }^{7}$ Ibid.
} 
Ironically, the military can be said to violate the very fundamental values of democratic discourse and rhetoric-freedom, transparency, and security-that it claims to protect. Such a hypocrisy has only been magnified in the wake of the terrorist attacks of September 11 , 2001, wherein new policies in surveillance, military technologies, and intelligence programs have opened up space for what it known as the 'safety state,' an agenda of public policy and cultural production centered upon information and communication management. Within this context, the development of post-9/11 military and intelligence operations resolves to maintain standard levels of public security while at the same time protecting classified federal interests. Whereas civilians are becoming increasingly transparent under state surveillance and military espionage, the executive branch of government has extended its claims to power with top secret programs and agencies, many of which are not subject to democratic regulation. ${ }^{8}$

Consequently, contemporary procedures of state security ironically generate forms of insecurity, which David Lyon notes is "an insecurity felt keenly by the very people that security measures are supposed to protect." 9 Despite the fact that the public has grown increasingly wary of domestic surveillance programs, it is precisely these feelings of insecurity that justify the classified status of military and federal operations. For Rancière, in the post-9/11 era, maintaining a community of feeling constellated around fear generates productive modes of civic participation in the state of advanced plutocratic consensus. "Insecurity is not a set of facts," as he claims, but rather "it is a mode of management of collective life; and one that is likely to persist even if our polities and institutions end up agreeing on an acceptable mode of life-in-common." ${ }^{10}$ Importantly, insecurity is an imagined horizon of affects that the military-industrial complex mobilizes in order to determine the qualities of civic experience. Reversing the message proclaimed by media outlets and official federal sources concerning the ostensive weapons of mass destruction in Iraq in 2003, Rancière contends that "imagined feelings of insecurity did not necessitate the war; instead the war was necessary to impose feelings of insecurity." ${ }^{\prime 11}$

Former Vice President Dick Cheney gestured to such a paradox in his remarks on post9/11 federal activities during an interview with NBC's Tim Russert on September 16, 2001:

\begin{abstract}
We also have to work, though, sort of the dark side, if you will. We've got to spend time in the shadows in the intelligence world. A lot of what needs to be done here will have to be done quietly, without any discussion, using sources and methods that a re available to our intelligence agencies, if we're going to be successful. That's the world these folks operate in, and so it's going to be vital for us to use any means at our disposal, basically, to achieve our objective. ${ }^{12}$
\end{abstract}

Here, invisibility in the "dark side" is not only a method for democratic policy, but rather it is an essential component to the legal and economic dimensions of the federal infra structure,

\footnotetext{
${ }^{8}$ Ina Zwerger and A rmin Medosch, "Goodbye Privacy! Hello Publicity?," in Ars Electronica 2007: Goodbye Privacy, ed. Gerfried Stocker and Christine Schöpf, trans. Mel Greenwald (Berlin: Hatje Cantz, 2007), 19 20.

${ }^{9}$ David Lyon and Zygmunt Bauman, Liquid Surveillance: A Conversation (C ambridge: Polity Press, 2013), 101.

10 Jacques Rancière, Dis sensus: On Politics and Aesthetics (London: Continuum, 2010), 108.

${ }^{11}$ I bid., 106.

12 "Meet the Press with Tim Russert: Dick Cheney," Meet the Press, NBC, Washington D.C.: NBC News Productions, September 16,2001; emphas is added.
} 
as the standard level of national security. And because this dark side-which includes anything funded by Congress' "black budget," ${ }^{13}$ such as planes, space, shuttles, satellites, and drones, as well as radioactive, biological, and chemical technologies - lies beyond the limits of common knowledge, it is largely unacknowledged and uncontested by the public, despite the obvious issue that such measures of invisibility contradict what many would declare to be democratic values. The feelings of insecurity produced by such classified activities thus overide and make possible any feelings of threat that might be produced were this dark side not in place. ${ }^{14}$ As Solnit observes: "On purely theoretical grounds, you can argue that invisibility is ... undemocratic; practically, it is ferociously so, again and again." 15

In his Limit Telephotography series, Paglen attempts to render visible geographic locations associated with the dark side of federal activity, terrain and facilities known as the "black world" or "black sites" of classified defense activity. These facilities are dedicated to anything from Special Force and CIA combat training centers to testing grounds for missiles, manned aircraft, drones, and electronic warfare systems. Certainly such black sites are present as actual locations, yet they are simultaneously absent from official forms of documentation and public discourse, thus forming what Paglen terms in the title of his 2009 book "blank spots on the map."16 It is Paglen's project to make visible precisely these locations that resist visibility and in fact require invisibility to maintain standard operating procedures. Through his limit-telephotography, Paglen not only gestures to the limits of trying to make these sites visible, but also to the limits of translating their presence into forms of knowledge which can then circulate in public discourse.

\section{An Image with Limits}

This translation performed by Paglen's camera is mired by noise from the surrounding atmosphere, as the high degree of magnification on Paglen's unique camera lens stretches the limitations of the photographic index to a point of abstraction. His practice of limittelephotography thus turns the representational potential of his images, as well as their appeals as documentary evidence, into nonfigurative fields of color, form, and line. Associations between Paglen's work and the visual register of Abstract Expressionism are no doubt apparent. Yet, certainly while Paglen's images are abstract, one might question if they are intentionally expressive in the same manner as the layered drips of Joan Mitchell's landscapes or Mark Rothko's meditative color fields. When encountering surveillance images, blurriness, pixilation, low resolution, scan lines, and glitches are often inflected as markers of a realist aesthetic. Specifically in Paglen's work, the hazy veneer that obscures and obliterates representational forms into grainy pastel swaths denotes a particular distance, geography, and climate, which Paglen typically articulates in the precise, almost clinical, titles reading with the exactitude expected of scientific inquiry and archival research - such as Chemical and Biological Proving Ground \#2 (2006) and Detachment 3, Air Force Flight Test Center (2008). Such titles insist on the veracity of the photographs and their fidelity to

\footnotetext{
13 Paglen, "The Expeditions," 3.

14 Solnit notes: "We do not debate the development of new systems of killing, the militarization of space, or the cost of our military budget, and most of us know nothing about the programs in question," 10 .

15 Solnit, "The Invisibility Wars," 12.

16 Trevor Paglen, Blank Spots on the Map: The Dark Geography of the Pentagon's Secret World (New York: Dutton, 2009).
} 
the surrounding environment and photographic conditions, despite the fact that such a degree of veracity is belied by the representational limits of limit-telephotography.

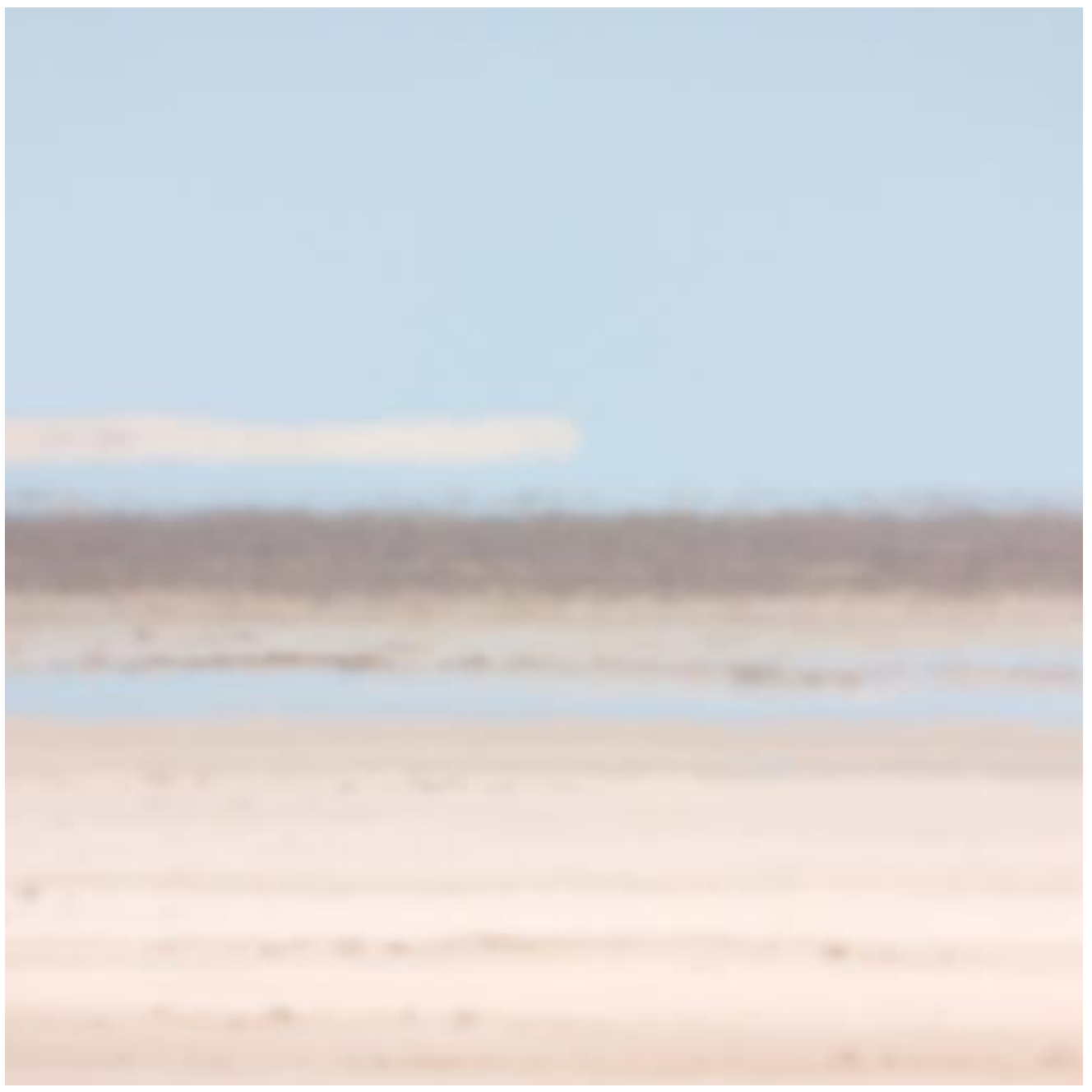

\section{Figure 2}

Trevor Paglen, Chemical and Biological Weapons Proving Ground/Dugway; UT/Distance approx. 42 miles; 11:17 a.m., from the Limit Telephotography series, 2006. C - print, $40 \times 40$ in. Copyright Trevor Paglen, courtes y the artist and Metro Pictures, New York; A Itman Siegel, San Francisco.

Perhaps then the visual abstraction emergent from Paglen's image-making pra ctice is less expressive than it is indexical. In this sense, it is possible to reconsider the aesthetic of Paglen's limit-telephotography as necessarily indexing the very practice of photographing black sites from extreme distances. Here, the visual register of these images do not preclude documentation, but rather makes it possible, thus constituting his images as forms of evidence of the process of limit-telephotography itself. The "limit" in Paglen's photography is negotiated through the unavoidable visual abstraction, which sets boundaries and restrictions on how his practice is able to perform a documentarian function under the guise of a surveillance aesthetic.

With abstraction invited into his images, Paglen's practice of limit-telephotography crystallizes a paradox of using photography to reveal certain types of truth about the government's dark side; he constructs a dual signification of what precisely is 'limited' in these images. On the one hand, Paglen's interests lie in making visible those spaces that are 
invisible to the naked eye, thus exposing the black sites that are just beyond perceptual limits at extreme distances. As Paglen remarks, "these photographs capture not only images of hidden places but images of what it looks like when the physical properties of vision are pushed to their limit, and light itself collapses into a jumbled mess." 17

On the other hand, Paglen is also confronting the limitations of our epistemic frameworks within the documentary genre. The tension between the unintelligibility of the photograph and the image's claims to indexicality reinforces the inherent paradox of documentation, one in which aesthetic modes of representation are expected to convey and analyze material realities without distortion or alteration. For Paglen, this paradox articulates "a negative dialectic"18 in the ways in which his limit-telephotography can function as both representation and documentation of the black world, such that his images "both make claims to represent, and at the same time dialectically undermine, the very claims they seem to put forth. ${ }^{19}$ In conversation with Julian Stallabrass regarding his aesthetic vocabulary, Paglen maintains a certain fidelity to the documentary potential of his limit-telephotography ("here's X secret satellite moving through X constellation") at the same time that he reflexively foregrounds their limitations as representational works ("your believing that this white streak against a starry backdrop is actually a secret satellite instead of a scratch on the film negative is a matter of belief"). ${ }^{20}$ The dialectic nature of this aesthetic system is not one that inevitably produces truth claims, but rather one that internally challenges, destabilizes, and contradicts its own appeals to knowledge production. Paglen's apparent failure of visualizing these sites due to certain abstractions via environmental mediation then simultaneously gestures to the impossibility of acquiring unequivocal truth from documentary practices, as well as the material and immaterial barriers that prevent access to information about the black world.

Here, Paglen extends such skepticism about his limit-telephotography within the documentary genre to certain discourses that have shaped contemporary U.S. involvement in militarized espionage, drone bombing, and war crimes. Concerning the infamous video of the Apache helicopter airstrike on Iraqi civilians that Chelsea Manning shared with WikiLeaks on July 6, 2010, Paglen states in his interview with Stallabrass: "I definitely agree with you that the WikiLeaks gunship footage is as good as we could reasonably want. But if there were a wrongful death lawsuit with that video as the prime piece of evidence, I wonder whether it would hold up in a courtroom." 21 Further referencing the video recording used in the Rodney King trial, which failed to testify as a form of evidence, and the photographs from Abu Ghraib, which Donald Rumsfeld dismissed as unrepresentative of the larger militaryprison system, Paglen's suspicion of representation informs his approach to the documentary image. As he claims: "Documentary media can still become social facts, regardless of how faithfully it reproduces reality [but] there's no magic image or documentation that exists outside or beyond the limits of representation."22 In this sense, it is not the case that Paglen

\footnotetext{
17 Trevor Paglen, "Sources and Methods," Invisible: Covert Operations and Classified Landscapes, ed. Trevor Paglen (New York: A perture, 2010), 146.

18 Paglen, "Sources and Methods," 151.

19 In conversation with Stallabrass, Paglen contends: "In terms of art-making, I sympathize with a revis ed form of negative dialectics as a response to an image-saturated society." Julian Stallabrass, "Negative Dialectics in the Google Era: A n Interview with Trevor Paglen," October 138 (Fall 2011): 9.

${ }^{20}$ I bid., 11.

${ }^{21}$ Ibid., 10 .

22 Ibid.; italics in the original.
} 
doubts the fidelity of such declassified materials or their unique possibilities to intercept and mobilize political action. Rather, Paglen asserts that the horizons of knowledge that emerge from any such encounter with the black world is rife with questions of representation, particularly how to represent what federal powers render unrepresentable-what Stallabrass refers to as "the limits of democracy, secrecy, visibility and what can be known."23

Yet, for Paglen, attempting to photograph these black sites is not merely a n artistic gesture, but also a form of resistance. His project has political concern at the same time that it invests in a particular aesthetic relationship to the black world. In conversation with the dark side of the federal infrastructure, such resistance often takes the form of visualizing the invisibility of the black world. One way that this form of political agency has historically taken shape is through revealing secret activities and disclosing classified documents - what is commonly regarded as whistleblowing, but constitutionally regarded as treason. In many of these cases, sharing top-secret intelligence constitutes a political opposition to federal power, thus resulting in violent state measures. In 1953, Ethel and Julius Rosenberg were executed for passing on atomic weapons secrets to the Soviet Union. ${ }^{24}$ In 1971, Daniel Ellsberg was tried under the 1917 Espionage Act for disclosing the United States Department of Defense history of the nation's involvement in Vietnam from 1945 to 1967, known as the Pentagon Papers. Such allegations of treason have likewise continued in response to individuals who have shared top secret information related to the increase of post-9/11 political-military activity; both whistleblowers Chelsea Manning and Edward Snowden were tried under the Espionage Act as well for disclosing classified federal documents to the public.

Snowden's case, due to its engagement with issues of surveillance, is particularly interesting in relation to Paglen's work, as it emphasizes the paradoxical relationship of visibility and invisibility within the democratic discourse on secrecy. Among the many top secret activities that Snowden disclosed in the leak of National Security Agency (NSA) documents in June 2013 is PRISM, a program which allows the NSA to gain direct access to the servers of the world's top telecommunications companies, including Google, Facebook, Microsoft, Yahoo!, Apple, and Skype, among others. Despite federal concern for public security, the type of surveillance observed in PRISM was made possible by the precise laws implemented in the wake of 9/11 that were designed to protect national security under the guise of democratic ideology, specifically the Patriot Act of 2001. According to journalist Glenn Greenwald, who collaborated with Snowden and documentarian Laura Poitras on the NSA leak, the underlying insidious nature of surveillance impinges on the right to privacy, which he claims is the "core condition of being a free person." 25 In this context, Green wald argues that Snowden's resistance should demonstrate the need to reverse the federal power structure: since the government consists of public servants working in the public sector, federal officials should be subject to complete visibility, while invisibility should be reserved for the private law-abiding individual. ${ }^{26}$ However, such a position is often contested by more conservative factions. As indicated in Cheney's remarks on the dark side of federal activities,

\footnotetext{
23 Stallabrass, "Negative Dialectics," 3.

${ }^{24}$ Section 2 of the Espionage Act of 1917,50 U.S. C ode 32 (now 18 U.S. Code 794), prohibits transmitting or attempting to trans mit to foreign governments information "relating to the national defense."

25 Glenn Greenwald, No Place to Hide: Edward Snowden, the NSA, and the U.S. Surveillance State (New York: Metropolitan Books, 2014$), 172$.

26 I bid., 209.
} 
such forms of invisibility, which justified the passing of the Patriot Act, are necessary for the economic and legal architecture of post-9/11 national security.

Like Snowden, Paglen invests himself through his limit-telephotography in a kind of resistance based on seeking out and exposing information embedded deep within the network of federal invisibility. For Solnit, Paglen situates his work as a form of resistance by locating his practice within a critical discourse that maintains the camera as a technology for revealing hidden realities. Drawing upon a rich history of photographic journalism, such as Robert Frank's The Americans and Richard Misrach's photographs of remote and classified military sites in the 1980s and 1990s, she underscores the camera as an agent for illuminating unknown phenomena, making familiar those things that are otherwise "unseen in plain view." 27 While photojournalism does not de facto constitute a form of resistance, within the context of the dark side of federal and military activity, Paglen's artistic practice articulates a potential to expose certain forms of knowledge that are otherwise invisible to the public eye. For Solnit, Paglen's work underscores the inherent paradox of the surveillance paradigm: "To see and to make visible is itself often a protracted process of education, research, investigation, and often trespassing and lawbreaking, a counter-spying on the intelligence complex."28

At close distances, Paglen does indeed capture certain kinds of information. Yet as a negative dialectic, this kind of resistance upends itself. Rather than actually revealing hidden realities, Paglen instead metaphorizes the veils of secrecy surrounding the black world by pushing the visual index to its abstracted limits. At extreme lengths, Paglen's images mirror the discourse of federal invisibility; through the index of surveillance aesthetics, information is not disclosed, but made more obscure. As Jonah Weiner of The New Yorker writes, "Paglen welcomes distortion in his images because his aim is not to expose and edify so much as to confound and unsettle." 29

In this regard, Paglen understands the truth-telling function of the camera merely as a pretense for examining the double-edged sword of counter-intelligence production, one in which surveillance can be used against itself in order to reconfigure the perceptual horizons of federal invisibility. By using advanced lens technologies to capture classified territory from miles away, Paglen introduces a diametric practice of enacting surveillance on precisely those black sites which themselves exercise espionage under a veil of invisibility, thus engaging in his own form of surveillance to observe sites of military espionage. His limit-telephotography thus turns military technologies of surveillance against themselves, exposing surveillance at the same time that it reproduces it. And as surveillance images, Paglen's work enacts a critique of surveillance by way of its own rhetoric. In this sense, the telescope lens, as Niels Van Tomme observes, "becomes a device embedded within the very violence it seeks to investigate, as such tools of vision are inextricably entwined with the history of, as well as ongoing standard developments within, the military industrial complex." 30 Arguably then, Paglen interrogates discourses of power in military operations of surveillance, thus prompting a reconsideration of the perceived objectivity of lens-based media within the context of

\footnotetext{
27 Solnit, "The Invisibility Wars," 10.

${ }^{28}$ I bid.

29 Jonah Weiner, "Prying Eyes," The New Yorker. O ctober 22, 2012. http://www.newyorker.com/magazine/2012/10/22/prying-eyes.

${ }^{30}$ Niels Van Tomme, "The I mage as Machine" in Visibility Machines: Harun Farocki and Trevor Paglen, exh. cat., (Chicago: Gallery 400,2015), 4.
} 
military operations, as well as the limitations of deploying surveillance to document our environment.

\section{The Politics of Relational Aesthetics}

Yet such a critique of surveillance does not automatically register a resistance to surveillance. If limit-telephotography does not disclose declassified information or reveal hidden realities, then the question for Paglen becomes: "How do I situate [a given] project in a productive situation, a political situation, and a discursive situation. Or, more tactically, how can I position [it] closely to a site of instability in power as possible such that [it] has real effects?" ${ }^{31}$ As opposed to the type of materials leaked by whistleblowers, it is doubtful as to whether or not Paglen's images could be used as evidence to mobilize political action or legislative response. However, while Paglen makes explicit that his photographs are "useless as evidence," he insists that limit-telephotography maintains a specific "politics of production." 32 He develops this term, emphasizing the various important practices that contribute to the production of his images:

In the vast majority of my artwork, the research, methods, and processes happening "outside the frame" a re just as important (and often more) a s what ends up being shown in a particular image or installation. All of [my] work . . . is the product of countless hours spent in libra ries, sifting through documents, conducting interviews, repeated site visits, careful planning and project management, and personal relations developed over years of dedication to the material. 33

Here, Paglen suggests that beyond his images there is a politic by which meaning is produced, a meaning which might be generative of alternative modes of engaging with the geopolitics of the black world infrastructure and its epistemic territories.

Paglen expands on this politic in a number of ways. On the one hand, he emphasizes the performance of limit-telephotography as a generative site of resistance-namely, on the right to stand in public land outside of the borders of the black world and turn his camera on the hidden realities of military activities. As Paglen argues, "[p]hotographing a secret military base means insisting on the right to do it, and enacting that right. Thus, we have a sort of political performance." 34 Interestingly, then, Paglen's performance of limit-telephotography conceives of this politic as a particular relation to the black world by reversing the very legal terms promoted by state order. On the other hand, he also speculates on the importance of relationships and networked practices that allow for his work to confront the perceptual limits of the black world. In addition to offering expeditions each year for individuals interested in exercising their right to photograph these bases $^{35}$, he writes:

\footnotetext{
${ }^{31}$ Emily Eliza Scott, "'Invis ible-5's' Illumination of Peripheral Geographies," Art Journal 69 no.4 (Winter 2010): 44

32 Weiner, "Prying Eyes"; Stallabrass, "Negative Dialectics," 6.

33 Paglen, "Sources and Methods," 144.

${ }^{34}$ Stallabras, "N egative Dialectics," 6.

35"I led several desert expeditions each year. These expeditions further developed the overall project, engaging participants as witnesses/spectators in an enactment of the right to see and to photograph. Instead of creating two-dimensional landscapes for galleries and museums, I was bringing people to the actual landscapes." Paglen, "The Expeditions," 3.
} 
I might be camping out on a mountaintop taking photos of a secret military base, or determining the location of CIA "black sites" so I can go photograph them. Maybe researching front-companies used in covert operations, or working with amateur astronomers to track classified spacecraft in Earth orbit. These are all relational practices and they all have various sorts of politics to them. 36

In his emphasis on the possibilities to inspire and organize geopolitical activism through relational practices, Paglen invokes Nicolas Bourriaud's description of relational a esthetics: "an art taking as its theoretical horizon the realm of human interactions and its social context, rather than the assertion of an independent and private symbolic space." ${ }^{\prime 37}$ In Bourriaud's wake, Paglen's practices can be read as relational in that such performances and relationships relocate the political agency from the image to the production process of limit telephotography. For Bourriaud, such practices lie in opposition to hegemonic capitalist regimes of commodity exchange, such that the relational artwork-which is less an object and more a form of social relation-essentially rejects subjugation into a market value system. The artist rather catalyzes sites of experience for collective encounters, bringing to bear new meanings and perceptual experiences as the art form. Unlike the passive optic encounter of an object, relational art is able to generate productive human relations, which, for Bourriaud, lays the seeds for political action through its emancipatory effects.

Yet, it is not quite clear that any and all relational practices will lead to political potentials. In Bourriaud's writing, sites of dialogue register forms of interactivity as democratic microtopias. Here, Claire Bishop has called into question the ways in which Bourriaud ties the structure of a relational work-its form as social relation-to its ethicopolitical effects while ignoring the veils of power and exclusivity that institutional systems use to acknowledge the communal experience as aesthetically valuable. ${ }^{38}$ For Bishop, participatory art should not be judged based on ethical standards of "consensual collaboration" between artist and audience during the production process. ${ }^{39}$ Rather, the political effects of participatory art emerge from its confrontation with audiences free from ethical fixations. Opposed to Bishop, Grant Kester in his 2004 book Conversation Pieces contends that the ethical framework is imperative to the political effects of participatory work, wherein dialogue between artists and non-artists constitute a consensual space for transformative experience. ${ }^{40}$

At the nexus of Bishop and Kester's writings on the political agency of relational practices lies an impasse between aesthetic autonomy and socio-political concerns. For Kim Charnley, such a paradox boils down to neutralization of political effects, such that both Bishop and Kester aim "to erase contradiction in order to maintain a consistent account of the political-and it is in the attempt to be consistent that the political is erased." 41 Here,

\footnotetext{
${ }^{36}$ Stallabrass, "Negative Dialectics," 6 ; emphas is added.

37 Nicolas Bourriaud, Relational Aesthetics, trans. Simon Pleasance and Fronza Woods (Dijon: Les presses du réel, 2002$), 14$.

${ }^{38}$ Claire Bishop, "A ntagonism and Relational A esthetics," October 110 (Fall 2004): 65.

${ }^{39}$ Claire Bishop, Artificial Hells: Participatory Art and the Politics of Spectators hip (London: V erso, 2012), $19-20$.

${ }^{40}$ Grant Kester, Conversation Pieces: Community and Communication in Modern Art (Berkeley: U niversity of California Press, 2013).

${ }^{41} \mathrm{Kim}$ Charnley, "Dissensus and the politics of collaborative practice," Art \& the Public Sphere 1 , no. 1 $(2011): 49$.
} 
politics can only emerge in a critical negotiation between the exclusivity of the artist along supporting institutional powers and democratic forms of social relations between artists and non-artists. In advancing this claim, Charnley draws from Rancière's writings on dissensus, wherein if "dissensus is not viewed as the vital element of socially engaged art then even the most rigorous ethics [via Kester] or carefully guarded autonomy [via Bishop] becomes an extension of consensus." 42

Important for this claim is the political nature of dissensus. According to Rancière, politics should not be thought of as the "exercise of power," but rather as an intervention in the normative relationship between actions, or ways of doing, and a possible horizon of affects, an aesthetic order that he terms the distribution of the sensible. ${ }^{43}$ This structural law delineates the general and common modes of participation in the social and the modes of perception that shape the experience of the social order. Politics, then, is a re-distribution of the sensible, such that political actions are those that disturb and expose gaps in the rationale underpinning the social body's implicit perceptual frameworks. Political demonstration then, as a dissensus, disrupts the sensible-what is visible and sayable - and brings about a change in the perception of social space, thus making "visible that which had no reason to be seen." 44

It is important to note, however, that Rancière is not proclaiming that politics brings to bear new perceptual possibilities in the sense that materials, people, and places, which were previously hidden, are suddenly made visible. This might too easily line up with a model of resistance to the black world based on disclosure of classified information, which Paglen's images in fact do not do. Rather, Rancière's interests rest in the ways that certain communities that had previously been denied subjectivity within the common social order might emerge, be recognized, and vocalize their perspectives. In his words:

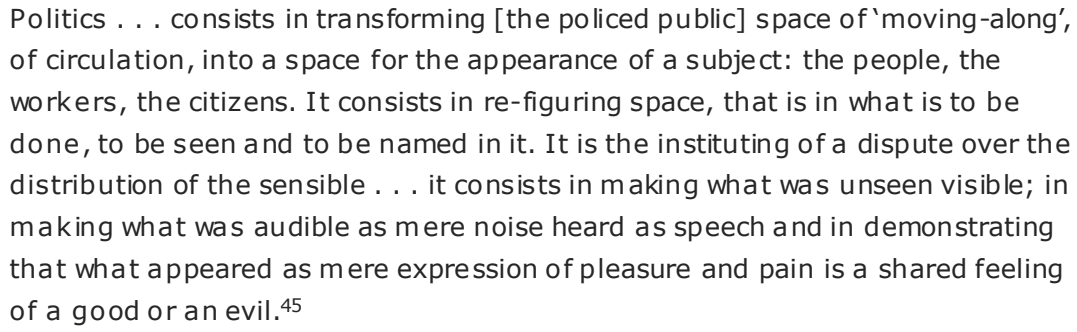

The core of political demonstration then is not just a reorganization of the social order's perceptual limits; it is also a question of space, of asserting that the communal experiences in private spaces of such unrecognized communities are valid alongside the public policed space of the common social order. It is the production of new spaces in which the previously unheard and unseen are recognized, in which the sensible is redistributed to allow for new meanings to generated and understood from previously insignificant materials, affe cts, and sensory experiences.

Understanding politics as a spatial discourse opens up new resistive possibilities for Paglen's limit-telephotography. It is thus not the case that Paglen's images are resistive in

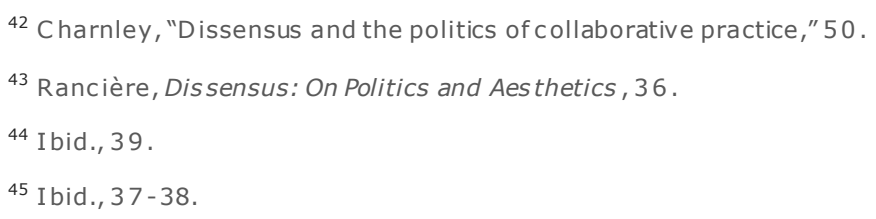


that they reveal information previously kept hidden by federal powers. Rather, in attempting to render the black world visible, Paglen interrogates the limits of what can be made sensible, forcing recognition of those things that federal powers hold beyond the boundaries of what can currently be perceived. He thus relocates the resistive agency of limittelephotography from the aesthetic register of the image to a spatial discourse of its political effects: interrogating the structural invisibility of militarized sites, the dimensional limits of representation through lens-based media, and the territories of knowledge about the black world that is continually rendered inaccessible by mechanisms of secrecy.

\section{Resistance: Experimental Geography as Dissensus}

In order to understand the production of limit-telephotography as a spatial practice, Paglen adopts what he refers to as a "critical geographic perspective." 46 Under this framework, he examines the two main theoretical underpinnings of geographic study: First, materialism, which employs an analytic approach to the idea that the world is made out of spatial interactions of materials; and second, the production of space, which refers to the dialectical ways in which space is actively constructed by human activity, and human activity is defined by space. Geography for Paglen "is not just a method of inquiry, but necessa rily entails the production of a space of inquiry." 47 With these two theoretical bases, Paglen understands the cultural production of limit-telephotography as necessarily a spatial practice, wherein he not only attempts to represent space by visually acknowledging the materiality of the black sites, but also contributes to the production of the space of inquiry, knowledge, and discourse about covert military operations and federal secrecy. ${ }^{48}$ By incorporating this approach into his practice, Paglen works through what he terms an "experimental geography":

Practices that recognize that cultural production and the production of space cannot be separated from each a nother, and that cultural and intellectual production is a spatial practice. Moreover, experimental geography means not only seeing the production of space as an ontological condition, but actively experimenting with the production of space as an integral part of one's own practice. 49

As a work of experimental geography, Paglen's limit-telephotography sets into relief the two theoretical frameworks of geographic inquiry. On the one hand, Paglen complicates the fieldbased perceptions of the landscape's material dimensions through its intentional abstracted

\footnotetext{
46 Paglen, "Experimental Geography," 37.

47 I bid., 31. Paglen comes to this conclusion by way of the theories of Marx and Lefebvre. Here, he accepts Marx's argument that a fundamental characteristic of human existence is "the production of material life its elf," that humans produce their existence in a dialectical relation to the rest of the world. Likewise, following Lefebvre, he also accepts that production is a fundamentally spatial practice, that humans create the world around them and are in turn created by the world around them. Thus, in light of both of these arguments, Paglen concludes that "cultural production (likeall production) is a spatial practice."

48 Paglen alludes to this analysis in his interview with The Rumpus: "It's helpful to think about state secrecy as a landscape, as a set of institutions and facts on the ground, in addition to a series of bureaucratic operations. In traditional social sciences, the way that you think about secrecy is in terms of bureaucracy and culture. I think that if you add geography to that, you can explain how secrecy works in a more robust way. And that also explains some of the failures of oversight [of] the secret state, historically."

49 Paglen, "Experimental Geography," 31.
} 
visual register. On the other hand, he also aims to produce new spaces of knowledge about that black world by questioning and reconfiguring their perceptual limits. Through material, perceptual, and epistemic spaces, he exposes gaps in the experiential horizons of the black world, and brings to bear new modes of participation with the black world that are technically legal, yet certainly disapproved.

Accordingly, Paglen's experimental geography begins to gesture to the ways in which the space of knowledge about the black world that is opened up by limit-telephotography can be inflected with political agency. As Paglen remarks, "[i]f human activities are inextricably spatial, then new forms of freedom and democracy can only emerge in dialectical relation to the production of new spaces. ${ }^{50}$ In framing his understanding of artistic production within geopolitics as a spatial discourse, particularly one that is dialectical, Paglen seems to echo Rancière's analysis of a dissensual politics. For the latter, politic demonstration registers a dialectical confrontation between the perceptual space of the sensible and imperceptible space of the political body-the result of which "is the construction of a paradoxical world that put together two separate worlds." 51 For Paglen, such a dialectical reading of a spatialized politics allows us to locate the resistive potentials of his work neither in the physical spaces that Paglen occupies in order to take his photographs nor the spaces in which one may encounter his works, but rather in the discursive space that critically situates the civic body against the geography of secrecy and invisibility of the black world. This is a dialectical space that emerges from a coming together of public knowledge and federal secrecy when the imperceptible is forced into recognition through a play of spatial discourses (whether in the image, its production, or in critical encounters). As Emily Eliza Scott contends, we might then approach the resistive potential of experimental geography "not in terms of their production of new images, objects, or experiences, but in terms of their production of potentially new spatial-political configurations. "52 Alan Ingram joins Scott in chorus, arguing that geopolitical art functions "not just as a form of resistance, refusal or critique but ... [as] an index of and contributor to political and spatial transformation." ${ }^{53} \mathrm{He}$ asserts that while it cannot be assumed that such creative interventions generate critical or radical results, they can produce the potential to represent the ways in which discourses shaping social and political life might be reproduced, changed, or disrupted. Here, Ingram grants particular emphasis to the potential for artistic practices to assume agency in mobilizing other kinds of action, rather than fully encompass the entire possible range of critical intervention or political resistance. Citing Rancière, Ingram continues: "the (geo)political effects of any particular artistic intervention cannot be assumed or inferred, only corroborated by corresponding actions. The question then becomes less what such art works mean than what critical approaches to geopolitics might do with them."54

Adopting a "relational way of thinking" into the spatial discourse of experimental geography insists on the ways in which Paglen negotiates and reconfigures the relations of production involved in creating cultural work about the geography of the government's black world, and further how that practice of reconfiguration can reveal new political horizons. Paglen remarks in this vein that "experimental geography takes for granted the fact that

\footnotetext{
50 Paglen, "Experimental Geography," 31.

51 Rancière, Dissensus: On Politics and Aes thetics, 39.

52 Scott, "'Invis ible-5's' Illumination of Peripheral Geographies," 44 .

53 A lan Ingram, "Making geopolitics otherwise: artistic interventions in global political space," The Geographical Journal 177, no.3 (Sept 2011): 218.

54 I bid., 221.
} 
there can be no 'outside' of politics, because there can be no 'outside' to the production of space (and the production of space is ipso facto political)." ${ }^{55}$ It is then not the case that Paglen's images contain the radical potential to subvert the discourses of secrecy operative in the black world, but rather that his practice of limit-telephotography produces the very political spaces from which these aesthetic objects may emerge. And because Paglen locates the possibilities for a resistive agency in the production of spaces for new human relations, he sets into relief the material and spatial concerns of an experimental geographic approach to the lived experience of producing limit-telephotography-from collaboration with field guides to occupying territory. Accordingly, Paglen is not attempting to breach federal secrecy by photographing black sites, nor is he exclusively concerned with negating the secrecy that manages black sites, as even the aesthetic register of his images reproduces the veil of invisibility that obscures access to seeing and understanding these spaces. Rather, limit telephotography emerges from a new system of relationships with the black world, one that provokes alternative and radical perceptions of the networks and representations of people, spaces, and power in the military-industrial complex. Paglen's documentary practice is one that negotiates the possibilities for rescuing material landscapes and geographic space from the black world in order to inspire the potential for critical engagements in the public sphere, or as Margarida Carvalho remarks in her work on geopoetics, "to inhabit [space] and make it communal." 56

\section{Towards a New Documentation}

As a collaborative art practice of experimental geography, Paglen's Limit Telephotography series questions itself on the grounds of how well these images serve as forms of documentation of the black world. Just as Paglen is skeptical about claiming that his photographs are documents of anything, the visual abstraction likewise prevents no rma tive modes of knowledge production at work in the documentary genre. Arguably, these images can only serve to index Paglen's physical presence at a particular location proximal to the military facility under investigation, which perhaps is mostly attributable to the precision of the titles of each photograph. In this sense, one might reason that Paglen's work is not only invested in documenting the black world, but also the process of occupying territory, or perhaps even the politics of production of limit-telephotography.

Yet, such a thesis fails to account for the inability to read this type of documentation in the images themselves. First and foremost, Paglen photographs classified military bases in the remotes recesses of the American Southwest, and not his own process of creating the se images in the form of photographs of expeditions and meetings with astronomers. He does not turn the camera on himself. Perhaps then the question becomes not how to documen $t$ a collaborative art practice, but rather how a collaborative art practice can function as a form of documentation. Here, Paglen remarks that the process of creating these images - from the project planning to the expedition-opens up the critical space from which these images appear: "I try to immerse myself in the 'world' of my research to the point where the

\footnotetext{
55 Paglen, "Experimental Geography," 32.

56 Margarida Carvalho, "A ffective Territories," INFLeXions Journal 3 (2009), 17 . Carvalho defines geopoetics as "a dynamic cartography in which localization and route are combined into subversive maps that highlight the creation of experimental, communal and creative strategies for appropriation and trans formation of both media and new technologies-namely those that are central to the current 's urveillance society'-as a means to enhance the sharing, creation and free flux of signals, things, people, actions, and affections," 15 .
} 
materials virtually 'tell' me how they want to be expressed." 57 Limit-telephotography thus emerges from the politics of production, not the other way a round.

Yet, to what extent do the politics of production of limit-telephotography - or further, the dialectical dissensus of experimental geographies-apply to other sites of encounter? In many ways, Paglen's consideration of that spatial discourse of relational a esthetics seems bounded to the artist and his creative process rather than extend beyond the production to the viewer who considers his work in a book, website, or exhibition. In these contexts, particular framing devices allow for these images to be located within a political agenda, such as gallery text, Paglen's artist biography, critical publications, and other kinds of paratextua I information. Yet, at the same time that these devices identify the political potentials of Paglen's experimental geography, they also nullify such effects by situating the vital dissensual properties of limit-telephotography within a consensual critical discourse-that is to say, such images are political because they are proclaimed to be so.

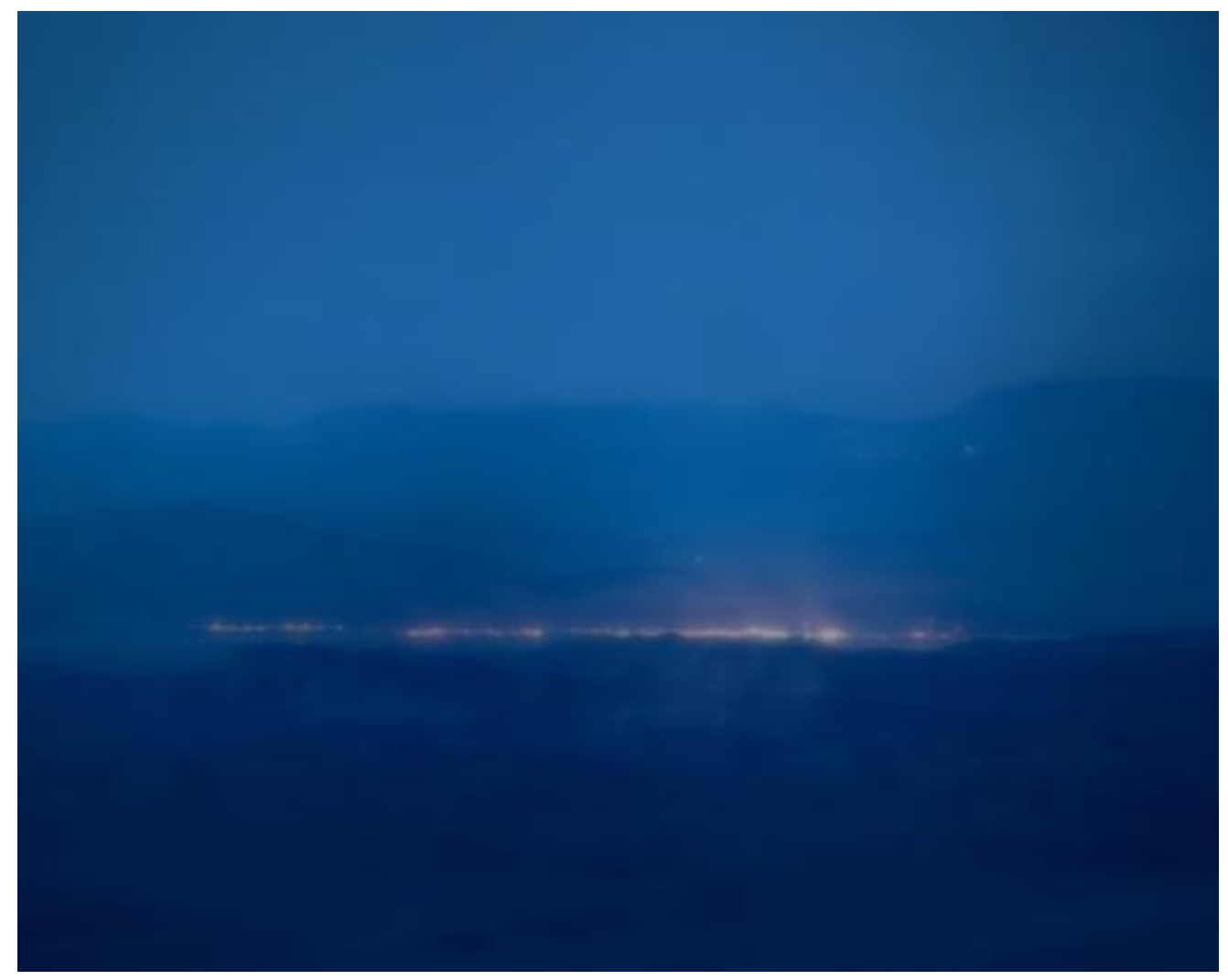

\section{Figure 3}

Trevor Paglen, Detachment 3, Air Force Flight Test Center, Groom Lake, NV Distanceapprox. 26 miles, from the Limit Telephotography series, 2008. C-print, $40 \times 50$ in. Copyright Trevor Paglen, courtesy the artist and Metro Pictures, New York; A Itman Siegel, San Francisco.

57 Paglen, "Sources and Methods," 144. 
Perhaps here we approach another 'limit' to Paglen's limit-telephotography: the limit of political agency itself. In reflecting on the relationship between dissensus and collaborative art practices, Charnley takes special note of Rancière's skepticism of collaborative works that confess themselves to be political "because it confuses the boundary between art and the social." ${ }^{58}$ Charnley continues:

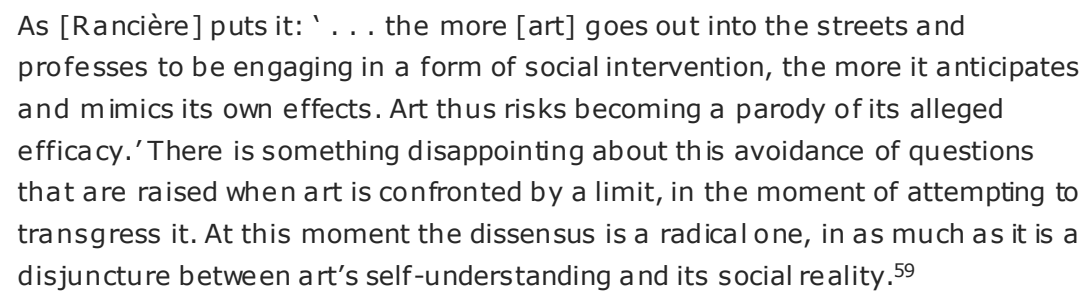

This limit, however, is not a deficit to Paglen's political aspirations, but rather an important nodal point for locating the resistive possibilities for a dissensual agency, which for Paglen, operates through his confrontation with the documentary genre. If the photographs are forms of documentation, then they confront the limit of political demonstration, but fail to surpass it. Because the images obscure evidence of the black world by metaphorizing the discourse of secrecy through the abstract visual register, they can only be political if they are labeled as such and qualified by paratextual information.

Yet, if we reconsider the collaborative art practice itself as the documentation of Paglen's encounter with the black world, then the visual register of limit-telephotography, which obscures evidentiary claims of the photographic index, should prompt viewers to turn away from thinking about the images as documentation in order to consider how the politics of production of limit-telephotography are attended by a multiplicity of effects, both in terms of their inception and reception, which may suggest or potentiate other kinds of agency. In this case, the encounter with limit-telephotography images would be a kind of participation in Paglen's collaborative network alongside those astronomers and fellow researchers that contributed to their production. The goal of this form of documentation becomes political when it negates the premise of its own appeals to knowledge formation. Paglen certainly doesn't illuminate anything about the black world, but perhaps he doesn't have to. When encountering his images, such sites suddenly become palpable, allowing for geographic material to enter into critical discourse. Even the most uninformed viewer who takes a sudden interest in the black world can gain political agency in seeking information, questioning sources of data, and joining others in protesting federal operations. Thus, while the political agency of Paglen's project cannot be located in the images themselves, it is possible to rethink how certain forms of engagement with limit-telephotography can reinscribe alternative modes of civic participation with the black world into the field of spatio political meanings articulated by the official aesthetic, legal, and constitutional forms of state power.

\footnotetext{
${ }^{58}$ Charnley, "Dissensus and the politics of collaborative practice," 51.

59 Ibid., 5 ; emphasis added.
} 
(cc)) $\mathrm{EY}$

New articles in this journal are licensed under a Creative Commons Attribution 4.0 United States License.

\section{ULLIS D-sulle}

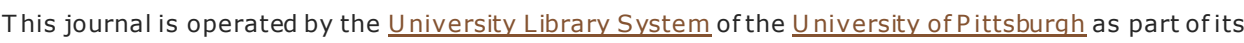
D-Scribe Digital Publishing Program, and is co-sponsored by the U niversity of Pittsburgh Press. 


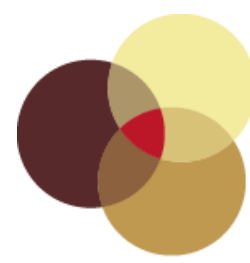

Vol 5, No 1 "Agency in Motion" (2016) | ISSN 2155-1162 (online) | DOI

\title{
Architectural Ruins and Urban Imaginaries Carlos Garaicoa's Images of Havana
}

Jodi Kovach

\begin{abstract}
Contemporary Cuban artist Carlos Garaicoa juxtaposes photographic images of Havana's architectural ruins with timidly articulated drawings that trace the outlines of the dilapidated buildings in empty urbanscapes. Each of these fragile drawings, often composed of delicate threads adhered to a photograph of a site after demolition, serves as a vestige of the sagging structure that the artist photographed prior to destruction. The dialogue that emerges from these photograph/drawing diptychs implies the unmooring of the radical utopian underpinnings of revolutionary ideology that persisted in the policies of Cuba's Período especial (Special Period) of the 1990s, and suggests a more complicated narrative of Cuba's modernity, in which the ambiguous drawings-which could indicate construction plans or function as mnemonic images-represent empty promises of economic growth that must negotiate the real socio-economic crises of the present. This article proposes that Garaicoa's critique of the goals and outcomes of the Special Period through Havana's ruins suggests a new articulation of the baroque expression - one that calls to mind the anti-authoritative strategies of twentieth-century Neo-Baroque literature and criticism. The artist historically grounds the legacy of the Cuban Revolution's modernizing project in the country's real economic decline in the post-Soviet era, but he also takes this approach to representing cities beyond Cuba's borders, thereby posing broader questions about the architectural symbolism of the $21^{\text {st }}$-century city in the ideological construction of modern globalizing society.
\end{abstract}

\section{About the Author}

Dr. Jodi Kovach is the Curator of Academic Programs at the Gund Gallery, Keny on College. Her scholarship focuses on contemporary Latin American art, specifically in the Mexican context. She has also taught art and design history, and has contributed to multiple exhibition catalogues, including Art of Two Germanys/Cold War Cultures (Los Angeles County Museum of Art, 2009), The Geometry of Hope: Abstract Art from the Patricia Phelps de Cisneros Collection (Blanton Museum of Art at University of Texas and Grey Gallery, NYU, 2007), Reality Bites: Making Avant-Garde Art in Post-Wall Germany (Mildred Lane Kemper Museum, Washington University, 2007), and Inside Out Loud: Visualizing Women's Health in Contemporary Art (Mildred Lane Kemper Museum, Washington University, 2005). 


\section{Architectural Ruins and Urban Imaginaries}

\author{
Carlos Garaicoa's Images of Havana
}

Jodi Kovach

Contemporary Cuban artist Carlos Garaicoa takes the architectural ruins of Havana as a point of departure for imagining new urban landscapes in Cuba's post-Soviet era. For example, his photograph/drawing diptych, El sueño de algunas ciudades es llegar a convertirse en otras (The Dream of Some Cities is to Become Another) (2001), shows pedestrians passing through a narrow city street in the heart of Havana's historic district, unencumbered by abandoned sewage trenches and rubble scattered through the passageway (fig. 1). They seem unconscious of the crumbling buildings that are literally collapsing around them - as if they are acquiescent to time's degenerative process, which has not only taken form in the architecture, but has also shaped their everyday existence. ${ }^{1}$ This atrophic ethos conveyed through the photograph has a strange, insidious vitality as nature overtakes the remaining fragments of architecture, creating a mass of wooden beams that look more like malignant outgrowths of the languishing buildings than structural supports. In his photograph of the site, Garaicoa highlights this corrosive dynamic by framing the image to focus on a makeshift arch of wooden scaffolding that braces the sagging structure against the building directly across from it in a desperate attempt to salvage the remains of the drooping edifice. Ironically, he then pairs this photograph with a small pencil sketch of the same scene in which he tamed the ungainly architectural forms by straightening lines and smoothing surfaces, by replacing the wooden buttresses with delicate bridges connecting the buildings, and by drawing a set of stairs leading up to an entryway in place of the beams that prop up the façade.

El sueño de algunas ciudades es llegara convertirse en otras highlights the conceptual underpinnings of a series of photographs for which Garaicoa used the deteriorating sectors of Havana as a touchstone in his practice of representing and imagining urban architecture through the lens of the ruin. In his depictions, the improvisational construction and persistent decay of these architectural relics culminate in a clichéd ba roque tragic beauty that he overwrites with provisional models and modifiable architectural plans. He pairs photographs of dilapidated architecture with drawings of imagined construction to examine the interplay between concepts of ruin and utopia, which have long figured differently in local and foreign perceptions of Cuba. Intertwined in tourists' exotic imaginings of Cuba's tragic baroque beauty, and enveloping the historical narratives of oppression and dreams of modern progress that together fueled revolutionary ideology, the ruin/utopia metaphor romanticizes the link between poverty and creativity, mythologizes m etaphors of Cuban resilience, and destabilizes the historicity of Cuban modernity. ${ }^{2}$ In the 1990 s, however, utopia - the Revolution's ideological dream of a unified, pan-Latin American socialist society-

\footnotetext{
${ }^{1}$ Benjamin describes the experience of space through architecture-it organizes experience, its presence is received collectively, unconsciously. The relationship is reciprocal: architecture shapes experience but also arises out of it. See Walter Benjamin, The Arcades Project, trans. Howard Eiland and Kevin McLaughlin (Cambridge, Mass. \& London: Belknap Press, 1999).

2 Lucia M. Suarez, "Ruin Memory: Havana Beyond the Revolution," Canadian Journal of Latin American and Caribbean Studies 39, no. 1 (2014): 38-55.
} 


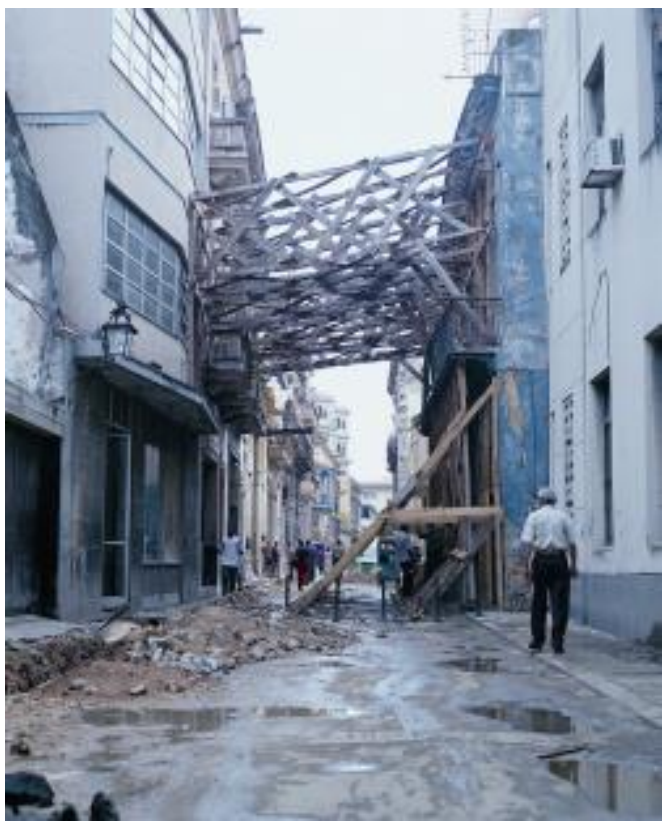

\section{Figure 1}

Carlos Garaicoa, El sueño de algunas ciudades es llegar a convertirs e en otras (The Dream of Some Cities Is to Become Another), 2001 . Left, Duraflex color photograph, $80 \times 60 \mathrm{~cm}$. Right, ink and graphite on board, $100 \times 70 \mathrm{~cm}$. Copyright Carlos Garaicoa.

became the catalyst of ruin in Cuba. ${ }^{3}$ The Revolution, already defeated following the dissolution of Soviet-led economic structure Comecon, represented nothing more than the desperate effort on the part of the Cuban government to continue its socialist agenda, isolating Cuba from the modern globalizing community. The policies of what is known as the Período especial (Special Period) ushered in a devastating economic crisis that crippled the country in the 1990 s and into this millennium. The galvanizing political slogan of the Special Period, iSocialismo o muerte!, in fact turned out to be a grim omen portending the ruin of the Cuban economy and its society. ${ }^{4}$ During this time Garaicoa made artwork that critically engages his city in ruins: his work appropriates the nostalgia of allegorical ruins to criticize the Cuban government's blind commitment to a defunct ideology, presenting photographic snapshots of contemporary architecture in disrepute alongside hesitantly executed drawings of the same buildings. Together, the images that comprise his diptychs suggest the

\footnotetext{
3 Luis Suárez Salazar and Carlos Perez, "The Cuban Revolution and the New Latin A merican Leadership: A V iew from I ts U topias," in "C uba: Interpreting a Half C entury of Revolution and Resistance, Part 2,"s pecial issue, Latin American Perspectives 36, no. 2 (March 2009): 114-127.

${ }^{4}$ Geraldine Lievesley, Cuban Revolution: Past, Present and Future Perspectives (New York: Palgrave Macmillan, 2004), 4 ; 161-168.
} 
unmooring of the radical utopian underpinnings of revolutionary ideology, and suggest a more complicated narrative of Cuba's modernity, in which tentative construction plans represent empty promises of economic growth that must negotiate the real socio-economic crises of the present.

This paper explores how Garaicoa intervenes in images of Havana's ruins through diptych photograph/drawings of dilapidated architecture before and after buildings were demolished. In the diptychs of urban scenes in Havana discussed here, I investigate Garaicoa's method of writing over the image of a site after a building's removal. Using delicate pencil or thread, he creates ghostly mirages of the demolished structures, thus reimagining what once existed rather than envisioning something new. These timidly articulated visions of reconstruction bear the persistence of Havana's present state of poverty, decay, and disrepair, which Garaicoa attributes to blind faith in the goals of the Cuban Revolution and the collapse of Eastern European communism. I propose that this strategy for critiquing the goals and outcomes of the Special Period through Havana's ruins suggests a new articulation of the baroque expression - one that calls to mind the antiauthoritative strategies of twentieth-century Neo-Baroque literature and criticism. I then show how the lens of Havana's failed modernity has shaped Garaicoa's perception of urban landscapes beyond Cuba, particularly in a photograph/drawing diptych in which he features the destruction/imaginary reconstruction of an unremarkable site in Los Angeles. A comparison of these two works demonstrates how the artist historically grounds the legacy of the Cuban Revolution's modernizing project in the country's real economic decline in the post-Soviet era, but also poses broader questions about the architectural symbolism of the $21^{\text {st }}$-century city in the ideological construction of modern globalizing society. ${ }^{5}$

Garaicoa's interpretations of ruins share affinities with the work of other conte mporary international artists like Cyprien Gaillard and Tacita Dean, for example, who represent Eastern European modernist architecture in its present dilapidated state to reveal the failure of its ideological underpinnings and to provoke consideration of what these ruins convey about the changes taking place in post-communist European societies. ${ }^{6}$ Garaicoa's ruins likewise criticize the fallacies of the Revolution and its promise of improving Cuban society, but his artwork also ironically reconstructs his downtrodden city. This seemingly paradoxical gesture is underscored by a sentiment of ambivalence about the future that has distinguished the work of his contemporaries in Cuba since the early 1990s. Specifically in Garaicoa's work, it is driven by the concern that development will not happen unless plans for social and economic progress are grounded in Cuba's material reality. ${ }^{7}$

\footnotetext{
5 A nthony D. King, Writing the Global City: Globalis ation, Postcolonialis m and the Urban (New York: Routledge, 2016), $75-79$.

6 See Francesca Picchi, "Modern Ruins: Intervista con Cyprien Gaillard/Interview with Cyprien Gaillard," Domus 926 (June 2009), 70 -73; P. A rdenne, "La terre est ronde - nouvelle narration," Art Press 238 (Sept. 1998): 72-73; and Sus an Stewart, "Tacita Dean," in The Open Studio: Essays on Art and Aesthetics (Chicago: University of Chicago Press, 2005).

7 Enwezor explains how contemporary artists working in Cuba, while not conforming to a specific style or conceptual practice, subvert the rhetoric of the State without completely as similating to contemporary "Western" art. See O kwui Enwezor, "Between A pparatus and Subjectivity: C arlos Garaicoa's Post-Utopian A rchitecture," in Carlos Garaicoa: Overlapping, ed. Enrique Juncosa (Dublin, I reland: I rish Museum of Modern A rt, 2010), 16-21. See also Abelardo Mena Chicuri, Cuba Avant-Garde: Contemporary Cuban Art from the Farber Collection (Gaines ville: University of Florida, 2007), $21-23$. This exhibition suggested that the juxtaposition of utopia with dys topian realities and ironic humor often found in contemporary Cuban art suggests a potential for new beginnings in the troubled post-Communist era.
} 
Growing up in Havana during the Cold War, Garaicoa saw the stagnancy of modernization in Cuba as a unique moment for critical reflection on the myth of progress that undergirds the country's modernist plans for societal reconstruction. Garaicoa explained:

After the fall of European socialism, many Cuban construction and architectonic projects were halted or abandoned. In Havana, as well as in other Cuban cities, idyllic and nostalgic ruins from the colonial and first republic periods coexist with the ruin of a frustrated political and social project. Unfinished buildings abound, neglected and in a sort of momentary oblivion. The encounter with these buildings produces a strange sensation; the issue is not the ruin of a luminous past but a present of incapacity. We face a never-consummated architecture, impoverished in its lack of conclusion, where ruins a re proclaimed before they even get to exist. I call these the Ruins of the Future. ${ }^{8}$

In this statement, Garaicoa describes Havana's ruins as the material embodiment of Cuba's inability to fully realize its socialist goals for implementing modernizing processes. He explained that as a child he found that the baroque aura of Old Havana's ruins, the palpable and material aesthetic of its decay, emanated a gritty authenticity that disclosed real existing conditions under Communism: "It was a very intense part of the city, a very poor area, dangerous in some places, but rich in its architecture and people...We would go walking in the streets competing to discover places none of us had ever noticed before. "9 Garaicoa's depictions of Old Havana's ruins do not aestheticize poverty and human suffering, nor do his images convey an exotic escape from modern life or express nostalgia for the greatness of a past era. In his work, decay disrupts the utopian imaginings of a society beyond the here and now; it is material, tangible, and present. Furthermore, the city is a metaphor for society's potential and, by contrast, the ruin is a device Garaicoa uses to represent the passage of modern time as fragmented and non-linear. This depiction of modern temporality through Havana's deteriorating urban landscape undermines the future-gazing of utopian imaginings.

Architectural ruins hold particular significance in urban imaginaries, both historical and modern. As a visual form, the ruin expresses the seventeenth-century Baroque fascination with decay and destruction. Using it to give form to his modernist conception of temporality, Walter Benjamin explained that the ruin in Baroque allegorical expressions concretizes the fragmentary movement of time and gives a layered picture of history. ${ }^{10}$ The ruin complicates notions of historical time as linear and evolutionary and for this reason is used in postmodern

8 Carlos Garaicoa in "Carlos Garaicoa by Holly Block," BOMB 82 (Winter 2003),

http://bombmagazine.org/article/2523/carlos-garaicoa

9 Carlos Garaicoa quoted in Marc Spiegler, "City Lights," in Trans(ient) City (Barcelona: Bom Publishers, 2008), 204.

10 The ruin represents the allegorical structure, which Benjamin contrasts against the "symbol," which embodies "momentary totality," as it is "self-contained, concentrated, steadfastly remaining itself." Benjamin's thes is on Baroque allegory criticized affirmative tendencies in the tradition of idealist philos ophy and laid the groundwork for what evolved into his modernist sensibility: the allegorical pers pective, or a way of describing nature through the fragment as opposed to a unified whole. For Benjamin allegory is dialectical, "a successively progressing, dramatic and mobile, dynamic repres entation of ideas which has acquired the very fluidity of time." See Walter Benjamin, The Origin of German Tragic Drama, trans. John O sborne (Frankfurt am Main: Suhrkamp Verlag,1963), 165. For Benjamin's ideas on historical materialism, see also "Theses on the P hilosophy of History," Illuminations, 262-263. A s Benjamin suggests, "[a] his torical materialist approaches a historical subject only where he encounters it as a monad. In this structure he recognizes the sign of a Messianic cessation of happening, or, put differently, a revolutionary chance in the fight for the oppress ed past." 
art to question the teleology of modernism. It figured in Robert Smithson's critique of modernism in the 1960 s and seventies when he depicted the architecture of suburban New Jersey as "ruins in reverse," or monuments to banality that rise, rather than fall into ruin, thus making visual the condition of entropy that Smithson believed characterized modern society. ${ }^{11}$ In postmodern expressions, the ruin is often viewed as the antithesis of utopia; it emphasizes the inescapability of a present state of dystopia with the same intensity that utopia reaches toward an unattainably perfect future. While utopia is pristine, intangible, and untouched by time, the ruin is concrete, worldly, and fragmented by time's ravages. ${ }^{12}$

In the years between 1995 and 2004, Garaicoa documented sites in Havana before and after abandoned or neglected architecture was torn down. From these he created a series of untitled diptychs, for which he then pinned red, green, or blue thread on the photographs taken after the demolition, outlining the razed buildings on the sites where they once sto od. For example, Sin título (Hotel San Carlos) (Untitled [San Carlos Hotel]) (1995-2004) includes two black-and-white photographs of the same site: a vacant and deteriorating seven-story building (fig. 2). The photograph on the right depicts the timeworn, hollowed-out encasement that was once the hotel. In the adjacent photo of the same site taken after the destruction, Garaicoa used red and blue thread to outline the geometric shapes of the slender windows, the superimposed pilasters ornamented with small scrolled capitals, and the carvings along some of the windowsills, all of which crumble and seem to fade into the surface of the façade. Both photographs were taken from the ground looking up, emphasizing the massiveness and verticality of the looming structure in spite of its state of decay. In the earlier photograph, the building hovers above this vantage point in the center of the composition and seems to force the smaller adjoining buildings to the edges of the frame. At the same time Garaicoa's oblique perspective emphasizes the building's vertical thrust, delineated by the narrow elongated windows and the lines of superimposed pediments that extend the entire length of the building, which nearly reaches the top of the frame. In contrast to this portrayed grandeur, the building's dark empty windo ws evidence its somber, haunting vacancy. Meanwhile a stray electrical wire extends from a streetlight and dramatically intersects the form of the hotel at a right angle, but this thin, tenuous line appears as useless and insignificant as the abandoned building in this completely uninha bited space.

Cuba's vernacular architecture, shown by Garaicoa in a state of disrepute, also expresses creative adaptation and inspires Garaicoa's ironic visions of reconstruction. ${ }^{13}$ The accumulation of multifarious styles, pulled together from European sources and modified for local purposes, is apparent in his diptych Sin título (Hotel San Carlos). Here, Garaicoa animates this dynamic, showing Havana's architecture simultaneously decaying and

\footnotetext{
11 Jennifer L. Roberts, "Smithson and Stephens in Yucután," in Mirror-Travels : Robert Smithson and History (New Haven \& London: Yale University Press, 2004), 110-112. See also Robert Smithson, "Incidents of Mirror-Travel in the Yucután [1969]," in Robert Smithson: The Collected Writings, ed. Jack Flam (Berkeley: University of California Press, 1996), 119-133.

12 Rahul Mehrotra, "Simultaneous Modernity: Negotiations and Res istances in U rban India," in Ruins of Modernity, ed. Julia Hell and A ndreas Schönle (Durham, N.C.: Duke University Press, 2010), 244-249. See also Benjamin, The Origin of German Tragic Drama, 66: "For as an antithesis to the historicalideal of restoration it is haunted by the idea of catastrophe."

13 Enwezor comments that, "[Garaicoa's ] work is inves ted in the investigation of the different architectural discourses of colonial, modern, and socialist city-making practices. This analysis subtends the late baroque buildings and enormous squares of Spanish colonial urban planning to the modernist experience of twentieth-century architecture and the centralized planning that represents the socialist inheritance of Cuba's post-revolutionary period." See Enwezor, 18.
} 
regenerating in a relentless cycle of ruin, particularly by confounding the order in which the viewer reads the process (did the plans for the building emerge before or after the blighted structure?). By portraying sites in Old Havana in this way, he reflects more broadly on the growth of Cuban vernacular architecture as the product of simultaneous additive and fragmenting processes that reproduce miscellaneous architectural fragments of the urban setting. ${ }^{14}$

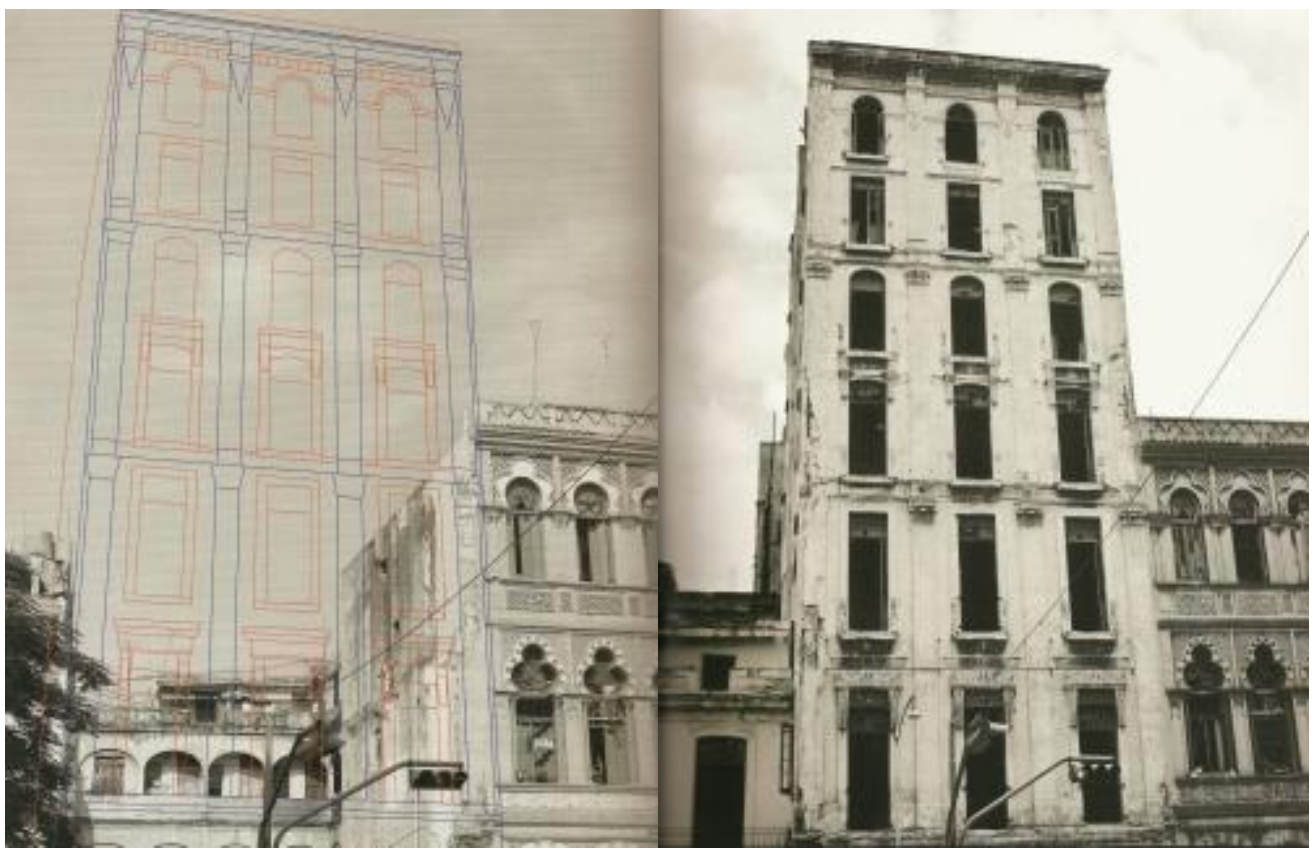

\section{Figure 2}

Carlos Garaicoa, Sin título (Hotel San Carlos) [Untitled (San Carlos Hotel)], 1995-2004. Diptych. Photographs and drawing with thread. $123 \times 100 \mathrm{~cm}$ each. Copyright $\mathrm{C}$ arlos Garaicoa.

Like many contemporary Cuban artists who emerged on the international art scene in the 1990s, Garaicoa critiques his country's communist revolutionary ideology through a specifically Cuban artistic voice that he draws from his country's rich "unofficial" aesthetic history, which emerges from Havana's architectural landscape. ${ }^{15}$ Baroque influences have shaped this aesthetic history from the colonial period to the present day. Modernist and postmodernist appropriations of baroque aesthetics informed an insurgent modernist perspective in Cuba the fifties, sixties, and seventies through Neo-Baroque literature and critical theory, while more recent iterations - in the work of Garaicoa, for example -e nable

\footnotetext{
14 Rachel Carley, Cuba: 400 Years of Architectural Heritage (New York: Whitney Library of Design, 1997).

15 Kerry O liver-Smith, "Globalization and the Vanguard," in Cuba Avant-Garde: Contemporary Cuban Art from the Farber Collection (Gaines ville: Samuel P. Harn Mus eum of A rt, U niversity of Florida), 21-23.
} 
the subversive critique of the official culture and politics of Cuba. ${ }^{16}$ Neo-Baroque literary theory composed in these decades by Cuban writers and scholars José Lezama Lima (191076), Alejo Carpentier (1904-80), and Severo Sarduy (1936-93) spearheaded notions of the New World Baroque as evidence of a period of artistic "invigoration" in Cuba, and of the origins of peculiarly Latin American and Cuban modernist sensibilities. As scholar of Spa nish literature César Augusto Salgado has demonstrated, the positive formulation of the New World Baroque as a regeneration of the European aesthetic model was augmented by Neo Baroque theorists in considering how this mutation functioned as a form of resistance within the oppressive regimes of colonialism. ${ }^{17}$

In the 1950s, Lezama Lima wrote about the broader significance of the New World Baroque and its revival to a pan-Latin American modernism. According to Lezama Lima, baroque expressions created in Latin America represented a form of resistance-a counterconquest culture that signaled the onset of a new modern sensibility. In other words, the New World Baroque was a collection of cultures operating outside of tradition, and which was concerned with the secular and the present, rather than with the theatrical styles and mystical content that characterize Spanish Baroque art. The New World Baroque a esthetics of rupture that Lezama Lima identified could then be used as a springboard for formulating a peculiarly Latin American modernist expression. According to Lezama Lima in his essay "La curiosidad barroca," the "barroco americano" is underscored by plutonismo, which he defined as an eruption of a deep-seated, subterranean creative impulse within an assimilated European style. The metaphor of a volcanic eruption, evoked to describe the productive, as opposed to the destructive, power of the baroque, connotes a resurgence of hidden grotesque impulses that break apart a unified, closed, balanced aesthetic and give way to open and inclusive forms. ${ }^{18}$

Alejo Carpentier saw the radical aesthetic qualities of the Cuban baroque in temporal terms: he discovered the modern baroque expression in the rhythms of New World

$16 \mathrm{O}$ this topic, Monika Kaup argues for a trans historical and transnational conception of the baroque, suggesting that "we need to replace the notion of a single baroque-usually identified with the European baroque of the Counter-Reformation and absolutism, masterfully analyzed in José Antonio Maravall's Culture of the Baroque-with that of multiple baroques." See Kaup, "'The Future is Entirely Fabulous': The Baroque Genealogy of Latin A merica's Modernity," in "Globalism on the Move," ed. Marshall Brown, special issue, MLQ68, no. 2 (June 2007): 233.

17 Cesar Augusto Salgado, "Hybridity in New World Baroque Theory," in "Theorizing the Hybrid," eds. Deborah A. Kapchan and Pauline Turner Strong, special issue, The Journal of American Folklore 112 , no. 445 (Summer, 1999): 316-331. Salgado notes that although New World baroque "often stands as a formula for a utopian ethnic integration, the neobaroque theorist also reminds us that this 'positive' mongrelization of European high styles resulted from the painful and incongruous overlapping of foreign and native morphologies in conflict."

18 José Lezama Lima, "La Curiosidad Barroca," en La Expresion Americana (Santiago de Chile: Talleres de Editorial Universitaria, S.A., 1969), 34. Lezama Lima portrayed the Baroque era as the explosive origination of modern Latin A merican culture, having stated that, "...we can say that among us the Baroque was an art of counter-conquest." He described the Baroque expression as "el fuego originario," or the creative force that dismantled decadent European traditions and opened art to creative input from many different cultural backgrounds. Lezama Lima's essay Lacuriosidad barroca, which he presented at the National Institute at Havana in January 1957 and published in his book of essays entitled La expresión americana that same year, describes the impact of Baroque culture on Latin American modernism. His theses on $\mathrm{Neo}$-Baroque aesthetics explore how rupture within an as imilated European artistic language was expressed through heteroglossic forms and poverty, means that opened onto new opportunities for artistic invention. 
improvisational forms like jazz. He believed that jazz gave form to variegated temporalities, which undercut the universal concept of time that buttressed power relations between the Old and New Worlds. As scholar Monica Kaup has discussed, Carpentier focused on a specifically Cuban Baroque that exemplified the dynamic processes observed by Lezama Lima in his theorizing of a broader, New World Baroque. ${ }^{19}$ Carpentier's version of an improvised, adaptive art form created by colonized subjects figures in Havana's unwieldy urbanscape in his 1964 text "La ciudad de las columnas" ("City of Columns"), in which he vividly describes an unsystematic, profuse accumulation of eclectic columns that line the streets of the city. ${ }^{20}$

The spontaneous character of Old Havana's vernacular architecture that intrigued Carpentier also captivates Garaicoa. The artist's decision to include in the compositions of both photographs for Sin título (Hotel San Carlos), the Mudéjar-style façade of the building next to the hotel points to the conspicuous presence of Moorish influences in Havana's colonial architecture which contributed to the unwieldy eclecticism of the Cuban Baroque style. Complete with trefoil window arches and elaborate geometric-patterned carvings, this building, juxtaposed with the less-embellished façade of the hotel, the street light, and the layers of sagging structures with arched porticos and awnings, hints at the multifariousness of Cuban vernacular architecture that resonates in the diverse architectural styles brought together in Havana's contemporary urban landscape. In photographs such as these, Garaicoa reveals Havana's architectural vista as the product of an erratic outgrowth of disparate stylistic fragments that have been modified, adapted, and cobbled together. In his images of architecture, baroque elements, as popular expressions of the Cuban people, reside within and beneath the ostentatious, yet crumbling, symbols of the colonial and communist authorities. ${ }^{21}$

Neo-Baroque theorists qualified Cuban Baroque forms as the subversive, crea tive means for breaking through the voice of authority to express multiple, marginalized perspectives. They developed a concept of the baroque expression in New World contexts to encompass new models of temporality and spatiality in order to represent modern experience in frameworks pertinent to everyday, vernacular experience. Severo Sarduy expanded on these notions in the 1970s when he conceived the Neo-Baroque modality as a de-centering force in art and literature that served to critique modernist spatial organizations based on unity and centrality. ${ }^{22}$ In Sarduy's work, the Neo-Baroque expression is a form of postmodern intertextuality that cuts through unitary languages. Inspired by what he identified in $\mathrm{New}$ World Baroque art as modalities of cultural assimilation, transformation, and demystification,

\footnotetext{
19 Monika Kaup, '"i V aya Papaya!': C uban Baroque and V isual Culture in A lejo Carpentier, Ricardo Porro, and Ramón Alejandro," PMLA 124, no. 1 (Jan. 2009):156-171.

20 See A lejo Carpentier, "La ciudad de las columnas," in Tientos y diferencias y otro ensayos (Barcelona: Plaza, [1964] 1987), 40 -48. See also Kaup, "'i V aya Papaya!,"'159.

21 "However, he does not view the phenomenon of abandonment of the old and the enthusiasm provoked by the new socialist form as separate entities...[He analyzes] how the architecture of the past and that of the present are both symbols of the imagination of otherempire-builders at the expense of the $C$ uban people." Enwezor, 18 .

22 Severo Sarduy, Barroco (Buenos A ires: Sudamericana, c. 1974). See also Sarduy "Dispersión (Falsas notas/Homenaje a Lezama Lima)," and "Sobre Góngora: la metáfora al cuadrado," in Es crito sobre un cuerpo:Ensayos de critica (Buenos A ires: Sudamericana, 1969). Sarduy draws influence from His panic Baroque literature and neo-Baroque tendencies in Latin A merican post-Boom literature. Sarduy's novels are labeled postmodernist, while his critical writings fit into discussions on poststructuralism.
} 
Sarduy sought to destabilize authoritative meaning in literature. This, in theory, could open a space for writers and readers to dissent from the patriarchal tone that the Cuban Revolution was taking on in the seventies. ${ }^{23}$

Garaicoa taps into the insurgent strategies of the Neo-Baroque, but moves beyond these authors' de-colonizing objectives. ${ }^{24}$ His ruin-gazing complicates a ste re oty pically ba roque fascination with decay and destruction, along with a fragmented version of history and temporality, and with this he confronts Cuba's incapacity to realize its revolutionary goals for social progress by incorporating this history, through images of the ruination of its urban landscape, into depictions of Cuba's current reality. In this way he eclipses the utopian visions of the Cuban Revolution by refusing to look directly to the future and leave his country's current state of socio-economic crisis behind. With the image of the ruin, as Walter Benjamin explained, "History merges into the setting...history is scattered like seeds over the ground." 25 More precisely, the thread drawings Garaicoa adds overtop the photographs frame a history lying in rubble. ${ }^{26}$ The building's destruction is transformed in his work -it becomes the impetus to rebuild. Still, the architectural plans merely repeat the form of the preexisting structure, and thereby serve as a bleak reminder of this part of the city that was destroyed. Garaicoa's architectural imaginaries focus on an absence that, for him, provides a possible framework for invention-yet one that must account for previous attempts at modernization and the problematic outcomes. ${ }^{27}$

Garaicoa explained that the juxtaposition of ruin/utopia in his art should "be understood not as a dream for the future but rather as an immediate action on reality - a lucid and conscious gesture concerning the collapsed present and the urban and political fabric of contemporary society. ${ }^{28}$ His work shifts between depictions of presence and absence, decay and regeneration, making the concepts of ruin and utopia a provocative pair: because they are intertwined, the images of decay and the architectural plans for the future always beg for more description, complicating notions of real and imaginary, as well as how the city exists in the past, present, and future. As a result, ruin/utopia becomes a format for thinking of the city historically, and for inspiring the imagination to explore ways of changing what exists not for envisioning what lies beyond it.

Garaicoa's imaginary of ruins therefore opens onto a revolutionary way of thinking about the present historically; in other words, of thinking of the present as part of a continuum of social, political, and cultural change. His historical perspective reflects on Cuba's position in

\footnotetext{
23 Carlos Garaicoa quoted in Inge Ruigrok "C uba: C ultural P olicy of N on-Western Countries," The Power of Culture, June 2006, http://www.krachtvancultuur.nl/en/policy/cuba.html.

24 Severo Sarduy and Roberto González Echevarría, "I nterview: Severo Sarduy," trans. Jane E. French, Diacritics 2, no. 2 (Summer 1972), $41-45$.

25 Benjamin, The Origin of German Tragic Drama, 92.

26 Previous exhibitions of Garaicoa's work have addressed the incipient utopian dimensions of his representations of Havana's visual decline, in which are also embedded dreams of transforma tion and redemption. See Carlos Garaicoa: Overlapping (Dublin: I rish Museum of Modern A rt, 20 10); Carlos Garaicoa: Capablanca's Real Passion (Prato: Gli O ri, 2005); and Carlos Garaicoa: La ruina la utopia (Bronx Museum of Art Bogota: Biblioteca Luis Ángel A rango Casa de Moneda, 2000).

27 A ndreas Huyssen, "A uthentic Ruins: Products of Modernity," in Ruins of Modernity, 17-28. Huyssen discusses "absence" as understood by Giovanni Battista Piranesi, Theodor A dorno, and A Ibert Speer.

28 Garaicoa in "Carlos Garaicoa by Holly Block."
} 
the postmodern world: Cuba is slowly emerging from what was formerly known as the Third World-the underdeveloped regions of the world that today produce political voices and cultural expressions that stand outside of, and contradict, what are often perceived as the homogenizing processes of globalization. Literary critic and Marxist political theorist Fredric Jameson, in considering the continued discrepancies of uneven development around the world, proposed that late capitalism could only come into being fully with the disappearance of the Third World. Within his theory, however, the Third World also provides a historical lens, or a chance to gain a historical foothold in the drive for attaining global modernization. Without this foothold we lose the capability to understand the conditions that have created real economic disparities, and therefore are unable to bring about sustainable social and economic development on a global scale. ${ }^{29}$

Garaicoa provides this historical lens when he focuses on isolated areas of major cities in the United States that remind him of Havana's decay. In fact, he admits he is incapable of seeing the world through any lens other than that of his lived experience in Havana. ${ }^{30}$ For example, a work he created similar to Sin título (Hotel San Carlos), entitled Sin título, L.A. (Untitled, L.A.) from 2004 is a diptych of a condemned office building in Los Angeles pictured before and after its demolition (fig. 3 ).

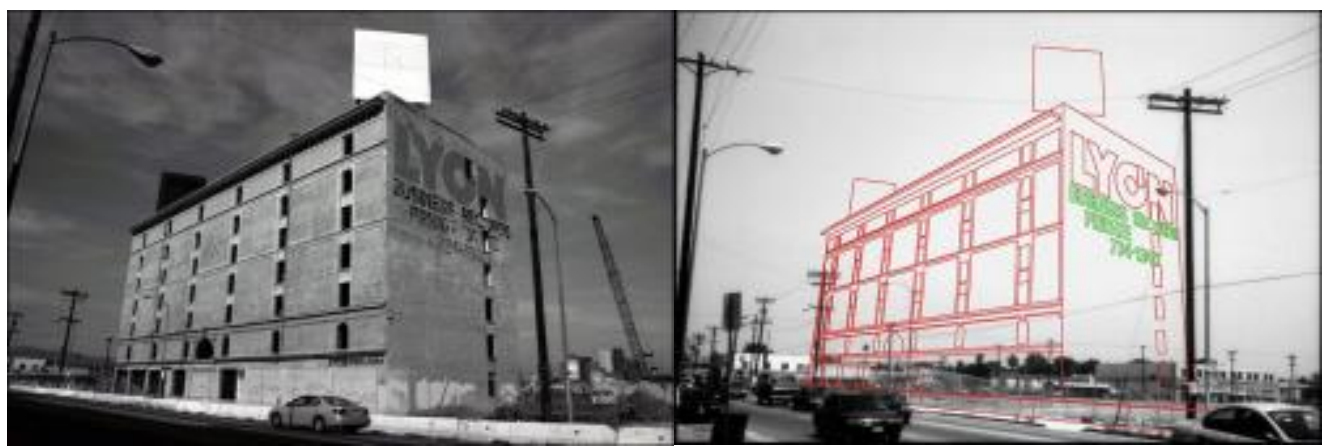

Figure 3

Carlos Garaicoa, Sin título, L.A. [Untitled, L.A.], 2004. Diptych. Photographs and drawing with thread, mounted and laminated on black gator board. $125 \times 175 \mathrm{~cm}$ each. Copyright Carlos Garaicoa.

In reference to his earlier photographs of the Cuban hotel, Garaicoa shot the black-andwhite photographs for this diptych from a low vantage point and filled the frame with, first, the structure, and in the second image, nearly the exact same site where it once stood. Also, he once again included signs of waning urban life: vacant lots, debris likely left from other demolition projects, and street lamps and telephone poles, anchoring electrical wires that indiscriminately traverse the space around the office building. Both photos show the site to be virtually uninhabited, with the exception of a few cars passing at the lower edge of the frame. Similar to Garaicoa's representation of the San Carlos Hotel, the Lyon building shown

\footnotetext{
29 For more on this topic, see Santiago Colás, "The Third World in Jameson's Postmodernis m or the Cultural Logic of Late Capitalism," in "Third World and Post-Colonial Issues," special issue, Social Text, no. $31 / 32(1992): 258-270$.

30 See Lorenzo Fusi, "A Conversation with Carlos Garaicoa," in Carlos Garaicoa: Capablanca's real passion (Prato, Italy: Gli Ori, 2005), 106.
} 
here was ultimately demolished, and the artist resurrects its image through a thread drawing. Furthermore, by exhibiting the two photographs of the L.A. site side-by-side, he makes it appear as if this building - and all of the stories contained within it-continues to haunt the city block on which it once stood.

Garaicoa does not forsake the disparities of modernity and inequities of globalization when using the same visual and conceptual strategies to represent Havana and Los Angeles in ruin/reconstruction. ${ }^{31}$ The ideological underpinnings of the ruinous site in L. A., however, are more ambiguous than those in his Havana diptych, and the convolution of history/present/future is more disorienting. The viewer, therefore, must interpret this work in dialogue with the artist's representations of sites in Havana. When comparing the two sets, the emptiness of these sites becomes apparent: closely framed and largely decontextualized from surroundings, and with little indication of human presence, Garaicoa directs our attention to the symbolic relationships among the urban architecture, in spite of their different social, political, and economic histories. Garaicoa employs the same visual vocabulary for both diptychs, presenting both structures in a perpetual cycle of ruin/reimagination, apparently mirroring Cuba's decline in his response to L.A.'s urban Iandscape. With this in mind, could these diptychs serve to challenge ideological assumptions about capitalist progress and communist stagnancy that bolstered the U.S. assertion of power and authority during the Cold War and have continued, until very recently, to help justify the U.S. embargo on Cuba? Perhaps Garaicoa's representation of the L.A. ruins therefore suggests an effort to expose and undermine what art historian Okwui Enwezor describes as the "opposed logics of contemporaneity," or in other words, the illusion of capitalism's presumed benefits in contrast to the deficiencies of Cuban communism. ${ }^{32}$ According to these images, the legacy of the Cold War, underpinned by conflicting myths of progress, afflicts both countries - two countries that have only recently begun to normalize diplomatic relations. ${ }^{33}$

Garaicoa reflects upon the ruins of his city as a starting point for envisioning societal renewal. His diptychs are not entirely dystopian; rather, in his work ruin is set against utopia, presence against absence, in ways that offer a layered conception of history. The concept of the ruin on which he expounds appropriates specifically baroque notions about time as a layered process, thus giving history an involuted rather than evolutionary movement. This historical perspective guides viewers to think critically about the economic,

\footnotetext{
${ }^{31}$ To nuance this relationship between the local and global, I am extrapolating from Ernesto Laclau, "Univers alism, Particularism, and the Question of I dentity," October vol. 61 (Summer 1992): 89. A s Laclau says, "[t]he universal emerges out of the particular not as some principle underlying and explaining it, but as an incomplete horizon suturing a dislocated particularidentity...the universal is the symbol of a missing fullness, and the particular exists only in the contradictory movement of ass erting a differential identity and simultaneously canceling it through its subsumption into a nondifferential medium."

32 Enwezor, 16.

33 See David Hart, Inside/Outs ide: Contemporary Cuban Art (Winston-Salem, NC: C harlotte and P hilip Hanes A rt Gallery, Wake Forest U niversity, 2003). See also William M. Leogrande and Julie M. Thomas, "Cuba's Q uest for Economic Independence," Journal of Latin American Studies 34, no. 2 (May 2002): $325-$ 363. Cuba's alterity to global power operations is unique, particularly within the varied geography of Latin A merican economic activity. O ver the course of the past two and a half decades, global economic activity has transformed power structures and polarized national economies within Latin America, causing, in recent years, for example, São Paulo to emerge as major center of global finance while countries such as Bolivia and $V$ enezuela continue to reinforce national boundaries and identities to protect their economies from liberalization. See also H. Michael Erisman and John M. Kirk, ed., Redefining Cuban Foreign Policy: The Impact of the "Special Period" (Gainesville: University Press of Florida, 2006).
} 
social, and ideological circumstances that put societies in ruin. Rather than simply forgetting the past to imagine utopias of the future, Garaicoa cast architectural plans and designs for urban living through the ruins of Havana to ground his visions for the city's regeneration in a concrete history and present socio-economic reality. Moreover, the fact that his sketches are easily modified, thus open to creative interpretation, may also suggest the potential to move beyond both the state of ruin and empty utopian promises.

(cc) BY New articles in this journal are licensed under a Creative Commons Attribution 4.0 United States License.

\section{ULLS D-Sonle}

This journal is operated by the $\underline{U}$ niversity Library System of the $\underline{U}$ niversity of Pittsburgh as part of its D-Scribe Digital Publishing Program, and is co-sponsored by the U niversity of Pittsburgh Press. 


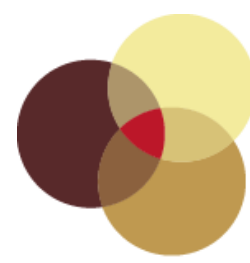

contennporaneity

Vol 5, No 1 "Agency in Motion" (2016) | ISSN 2155-1162 (online) | DOI

10.5195/contemp.2016.184

http://contemporaneity.pitt.edu

\title{
Documenting/Performing the \\ Vulnerable Body
}

Pain and Agency in Works by Boris Mikhailov and

Petr Pavlensky

Ingrid Nordgaard

\begin{abstract}
This article explores the concepts of pain and agency in the photography series Case History (1997-1998) by the Ukrainian photographer Boris Mikhailov, and in four performance-actions (2012-2014) by the Russian performance-activist Petr Pavlensky. Although they represent different generations and respond to different historical contexts, Mikhailov and Pavlensky share a focus on the wounded body. Taking both the documentary and performative aspects of these artworks into account, Nordgaard argues that the wounded body stands forth as a body of agency which also reflects the social, political, and historical settings in which it exists. The relational consideration of the two artists therefore offers important insights for understanding post-Soviet Ukraine and present-day Russia, and reflects on the correlation between the private and the public body. By placing Mikhailov and Pavlensky in dialogue with a broader discussion on spectatorship and the role and significance of "shock imagery" and spectacle in contemporary media, the article further suggests why artworks depicting the body in pain have both an ethical and political function.
\end{abstract}

\section{About the Author}

Ingrid Nordgaard is a PhD student in the department of Slavic Languages and Literatures at Yale University. She holds a Bachelor of Arts in Russian Studies from the University of Tromsø, Norway, and in 2013, she completed a Master of Arts in Russian Studies at New York University. 


\section{Documenting/Performing the Vulnerable Body}

\author{
Pain and Agency in Works by Boris \\ Mikhailov and Petr Pavlensky
}

Ingrid Nordgaard
In September 2015 when the European refugee crisis was at its most pressing, a photograph of toddler Aylan Kurdi lying dead on a beach in Turkey circulated in international media. As Adam Withnall of the Independent phrased it in a headline: "If these extraordinarily powerful images of a dead Syrian child washed up on a beach don't change Europe's attitude to refugees, what will?" Withnall added, "[t]he Independent has taken the decision to publish these images because, among the often glib words about the 'ongoing migrant crisis,' it is all too easy to forget the reality of the desperate situation facing many refugees."1 From Whithnall's point of view, the distressing image moved beyond the confines of the seemingly habitual everyday reporting of human tragedy. Shortly after, however, online news sites commented on the image taken by photojournalist Nilüfer Demir, only this time the headlines did not express a call for mercy and action but were rather set on exposing the truth behind the image: "Aylan Kurdi's father denies claims he was a people smuggler and driving boat that capsized and led to son's death;" "Europe's policy did not kill Aylan Kurdi ;" "'Aylan's father just wanted better dental treatment': Liberal Senator Cory Bernardi's brutal claim that drowned Syrian boy wasn't a 'real refugee'." 2 In the months following the death of Kurdi, the French satirical magazine Charlie Hebdo published several cartoon versions of the image, accompanied by headlines such as "What would've become of Aylan had he grown up? -A groper." 3 Suddenly the tragic fate of the helpless three-year-old was used to complicate the narrative of the European crisis: as if the image caption that once read "This is tragic" now stated "This is tragic, but...."

On the one hand, the example above shows how we believe that images could have the power to change attitudes. This stance aligns with William Stott's claims about social documentary photography of the 1930s, which he stated "encourages social improvement" by making us feel implicated through portraying social situations that may be altered. ${ }^{4} \mathrm{On}$ the other hand, some of the photograph's reception suggests that such hopes are futile in the context of contemporary media. In our ever-changing media reality, the distinction between media-producer and media-consumer is increasingly ambiguous: interactive social media frequently intersect with traditional news reporting, and online self-publishing blurs the boundary between critical journalism reporting and opinion pieces. While one may argue that such a media landscape supports openness, transparency, and diverse outlooks, it could also distort the distinction between reality and fiction, and news reporting and

\footnotetext{
${ }^{1}$ A dam Whithnall, "If these extraordinarily powerful images of a dead Syrian child was hed up on a beach don't change Europe's attitude to refugees, what will?," Independent September 2, 2015 , http://www.independent.co.uk/.

${ }^{2}$ Respectively, A ndrew Griffin in Independent, September 13, 2015, http://www.independent.co.uk/; Crispian C uss in Al Jazeera, September 4, 2015 , http://www.aljazeera.com/; and Louise Cheer in Daily Mail, September 8,2015, http://www.dailymail.co.uk/.

${ }^{3}$ See, for example, A manda Meade, "Charlie Hebdo cartoon depicting drowned child A lan Kurdi sparks racism debate" in the Guardian, January 14,2016, https://www.theguardian.com/.

${ }^{4}$ William Stott, Documentary Expression and Thirties America (C hicago: University of Chicago Press, 1973), 21 and 26, respectively.
} 
entertainment, thus slowly erasing the difference between media consumption for informational and for entertainment purposes. This is perhaps especially true in cases that involve human suffering or pain; we have become so accustomed to seeing pain in the media that the potential of an empathic viewing of the tragedy and despair of others seems lost - a statement that has certainly become a cliché, but that still rings true.

The fact that the image of Aylan Kurdi triggered such an overwhelming response discloses how public display of pain is inherently connected to discussions of ethics, voyeurism, general media consumption, and spectacle. ${ }^{5}$ More important, the photograph reveals how fragile the wounded body is when captured without knowing, unable to give consent to its own visibility or simply becoming part of larger narratives over which it has no control. The appearance of presumed pain in such documentary images may help us conceptualize, understand, and provide photographic evidence for global suffering, but it is also too easy to ignore its presence or to question it-as seen in the case of the Syrian toddler.

This paper explores the relationships between photography, agency, spectatorship, and pain in works by the Ukrainian photographer Boris Mikhailov (b. 1938) and the Russian performance-activist Petr Pavlensky (b. 1984). These two contemporary artists have addressed the body in pain and its visual presentation using both photography and live bodily performance. Representing different generations and working in different social and art historical contexts, Mikhailov and Pavlensky nevertheless share the goal of capturing bodily vulnerability and revealing the physical impact of social and political injustice on the human body. In Mikhailov's photograph series Case History (1997-98), homeless people openly exhibit their wounded, naked bodies in front of his camera. Pavlensky, in the performance-actions Seam (2012), Carcass (2013), Fixation (2013), and Segregation (2014), mutilates his own body publically in some of the most symbolically laden locations in Russia. Although what follows is not an explicit comparison of the two artists, a relational consideration is productive because both Mikhailov and Pavlensky refuse to present the wounded body as a powerless victim. Instead, I argue that the wounded body in their works represents a way of exposing and contending with external factors that may be harmful not only to the individual, but to all of us. It is my hope that a discussion of the two artists will offer new perspectives on the making and distribution of photographic images of bodies in pain, and on the fraught correlation between the artist, the photographic subject, and the spectator.

\footnotetext{
${ }^{5}$ Debord claims that with the intense focus on production in the modern age, everything has become mere representation characterized by spectacle, "a social relation between people that is mediated by images." Guy Debord, The Society of the Spectacle, trans. Ken Knabb (Berkeley: Bureau of Public Secrets, 2014), 11 . Indirectly following Debord's notion of the global spectacle, P hil C arney argues that photography is a "social practice of production" and a strong social force; the photograph produces more than it represents. Whether or not photographic images are depicting what is "real" or mere fantasy is beside the point, as Carney is more interested in showing how photographic images are parts of how we define our lives. Carney, however, does not linger on the negative impacts of the (photographic) spectacle, but like Debord he points out that it defines the way we live. The reality of social practice can indeed be seen through the photographic spectacle, but it is also produced by it: the photograph must be seen as a performative force. See P hil C arney, "C rime, P unishment, and the Force of P hotographic Spectacle" in Framing Crime: Cultural Criminology and the Image, eds. Keith J. Hayward and Mike Presdee (New York: Routledge, 2010). Sus an Sontag, among others, has criticized the concept of s pectacle: "[t]o speak of reality becoming a spectacle is a breathtaking provincialism. It universalizes the viewing habits of a small, educated population living in the rich part of the world, where news has been converted into entertainment." See Sus an Sontag, Regarding the Pain of Others (New York: Picador, 2003), 110.
} 


\section{The Photographic Subject in Pain: Context and Representation}

Before discussing Mikhailov and Pavlensky on their own terms, some context should be given regarding the photographic medium and photography's presumed relationship to pain and its representation. Moreover, it is also worth asking what type of response such images may trigger in the viewer. In her famous account On Photography (1977), Susan Sontag claims that photographic images have lost their ability to trigger an ethical response in the spectator, because visual representations of suffering have become commonplace and are inherently linked with sensationalism. In Sontag's account, such images create a "chronic voyeuristic relation" to the world. ${ }^{6}$ In a similar vein, Martha Rosler's 1981 essay "In, Around, and Afterthoughts (On Documentary Photography)" offers a substantial critique against the notion that documentary photography can give a truthful account of "reality." Claiming that documentary photography only offers empty remarks about the "conditions of man," Rosler states that the common idea "that documentary precedes, supplants, transcends, or cures full, substantial social activism is an indicator that we do not yet have a real documentary."7 In other words, documentary photography may pacify the viewer by reaffirming the distance between the photographic subject and the spectator, rather than function as a call for action.

The remarks made by Sontag and Rosler raise important points about the photographic subject and the spectator, contemporary media, and the aestheticization of suffering. In addition, it indirectly addresses the issue of agency. According to Sontag, the act of taking a picture is somewhat predatory because it violates people by turning them "into objects that can be symbolically possessed." ${ }^{8}$ From Sontag's point of view, the photographer is in complete control, whereas the people in the images are objectified and robbed of agency, as both Sontag and Rosler argue is the case in Diane Arbus's photographs of social "outsiders." Photographing wounded, differently-abled, and non-normative bodies highlights the nonconformity of these bodies, which emphasizes the photographer's power but also victimizes the photographic subject. As I understand Sontag and Rosler, to be victimized is the same as being deprived of personal agency. This is perhaps articulated most clearly in Rosler's essay, which states that traditional documentary photography "carries (old) information about a group of powerless people to another group addressed as socially powerful."10

\footnotetext{
${ }^{6}$ Susan Sontag, On Photography (New York: Farrar, Straus, and Giroux, 1977), 11. Jacques Rancière offers a different approach to "intolerable images" and their distribution in relation to the question of ethical response. Rancière convincingly argues that our systems of information do not operate through an overabundance of horrific images, but by "selecting the speaking and reasoning beings who are capable of 'deciphering'the flow of information about anonymous multitudes. The politics of its images consists in teaching us that not just anyone is capable of seeing and speaking. This is the lesson very prosaically confirmed by those who claim to criticize the televisual flood of images." Rancière, "The Intolerable Image" in The Emancipated Spectator, trans. Gregory Elliott (London; Brooklyn, NY: V erso, 2009 ), 96. While Rancière's obs ervations are an important contribution to the discussion of photographic images and their distribution, my paper will not follow his line of inquiry.

7 Martha Rosler, "In, A round, and A fterthoughts (O n Documentary Photography)" in Decoys and Disruptions : Selected Writings, 1975-2001 (Cambridge, MA; London: M IT Press, 2004), 196.

${ }^{8}$ Sontag, On Photography,14.

${ }^{9}$ Sontag for instance writes: "The ambiguity of A rbus's work is that she seems to have enrolled in one of art photography's most visible enterprises - concentrating on victims, the unfortunate, the dis possessedbut without the compassionate purpose that such a project is expected to serve." See S ontag, "Freak Show," New York Review of Books 20, no. 18 (1973), http://www.nybooks.com/articles/1973/11/15/freak-show/.

${ }^{10}$ Rosler, "In, A round, and A fterthoughts," 179.
} 
In Regarding the Pain of Others (2003), Sontag engages with her former work on photography and further grapples with the medium's ethical implications. Commenting on some of the most harrowing images from the past two centuries, Sontag struggles with the question of photography's value. Although skeptical of the medium's ability to convey reality, Sontag implores the atrocious images to haunt us, as photography depicting suffering potentially is "an invitation to pay attention, to reflect, to learn, to examine the rationalizations for mass suffering offered by established powers." 11 However, Sontag does not explicitly address the photographic subject's agency, but rather focuses on the spectator's reaction to the images of wounded bodies. It therefore seems as if Sontag is still hesitant to approach the body in pain as a body with agency. In the following, I will show how Mikhailov and Pavlensky challenge such a position as the wounded body in their works stands forth as a body that may bear the actions of others, but also has the capacity to act.

\section{Boris Mikhailov's Case History: Documenting History and Delegating Performance}

As a result of the dissolution of the Soviet Union, the city of Kharkov, Ukraine, went through dramatic changes over the course of the 1990s. ${ }^{12}$ Gradually, the city was covered with foreign advertisements-bright and colorful manifestations of the newly accumulated wealth of a fortunate few and in stark contrast to overwhelming signs of poverty. Watching his home city change before his eyes, Boris Mikhailov became astutely aware of a new presence in the modern cityscape: a great number of homeless people. Whereas Kharkov had undergone the transition from communism to a market economy, neo-liberal reforms, hyperinflation, and the downsizing of social welfare systems, these were the people who had lost their homes and received no state support. Wanting to document the historical moment, Mikhailov embarked upon a project that took two years to finish and resulted in Case History (completed in 1999), a series of more than four hundred life-sized color photographs portraying the lives of homeless people in Kharkov. ${ }^{13}$

An active photographer since the 1960 s, Mikhailov has received international acclaim for his numerous photography series. ${ }^{14}$ While his early work to some extent shared the conceptual framework of Moscow Conceptualism (associated with figures such as Ilya

\footnotetext{
${ }^{11}$ Susan Sontag, Regarding the Pain of Others (New York: Picador, 2003), 117.

$12 \mathrm{U}$ kraine gained its independence from the Soviet U nion in 1991 . The years to come would be marked by dramatic economic decline. A ccording to the World Bank, in 1991 the GDP per capita was \$1,490; by 2000 it had fallen to $\$ 636$.

13 The historical specificity of Case History is important. In the Soviet Union, it was strictly forbidden to take photos in specific public spaces, to develop photos that might question or criticize Soviet ideology and everyday life, and to photograph naked bodies. Explaining his reason for creating Case History, Mikhailov stated, "[h]aving these laws and their consequences in my memory, I was aware that I was not allowed to let it happen once again that some periods of life would be erased"in Boris Mikhailov, Case History (Berlin: Scalo, 1999), 7.

${ }^{14}$ Mikhailov was born in Kharkov, Ukraine (USSR) in 1938, and began his career as an amateur photographer in the 1960 s. By the late 1960 s, Mikhailov had finished what is acknowledged as his first larger photography series, Superimpositions, and he soon became a figure within the unofficial art scene in the Soviet Union. In 1976, he quit his job and devoted himself entirely to his photographic work. By the early 2000 s, Mikhailov had made twenty-six photography series. In 2000 , he was awarded the Hasselblad Foundation International A ward, considered by many to be the most prestigious recognition in

contemporary photography. For a cohesive account of Mikhailov's stylistic and formal development as a photographer, see Urs Stahel, "Private Pleasures, Burdensome Boredom, P ublic Decay-an Introduction" in Boris Mikhailov: A retrospective/Eine Retrospektive, ed. U rs Stahel (Zurich: Scalo, 2003), 12 -17.
} 
Kabakov, Erik Bulatov, Viktor Pivovarov, and Andrei Monastarsky), his post-Soviet series speak directly to the state of confusion, disillusionment, and the collapse of order that followed as a result of the dissolution of the Soviet Union. ${ }^{15}$ Case History marks a pivotal point in Mikhailov's photographic documentation of post-Soviet reality. Several of the photographs show explicit nakedness or human suffering, and the series includes photographs of animals, children, Mikhailov himself and his family members, objects or rooms, and cityscapes. The images therefore depict not only the situation of the homeless, but also reflect general life in Kharkov.

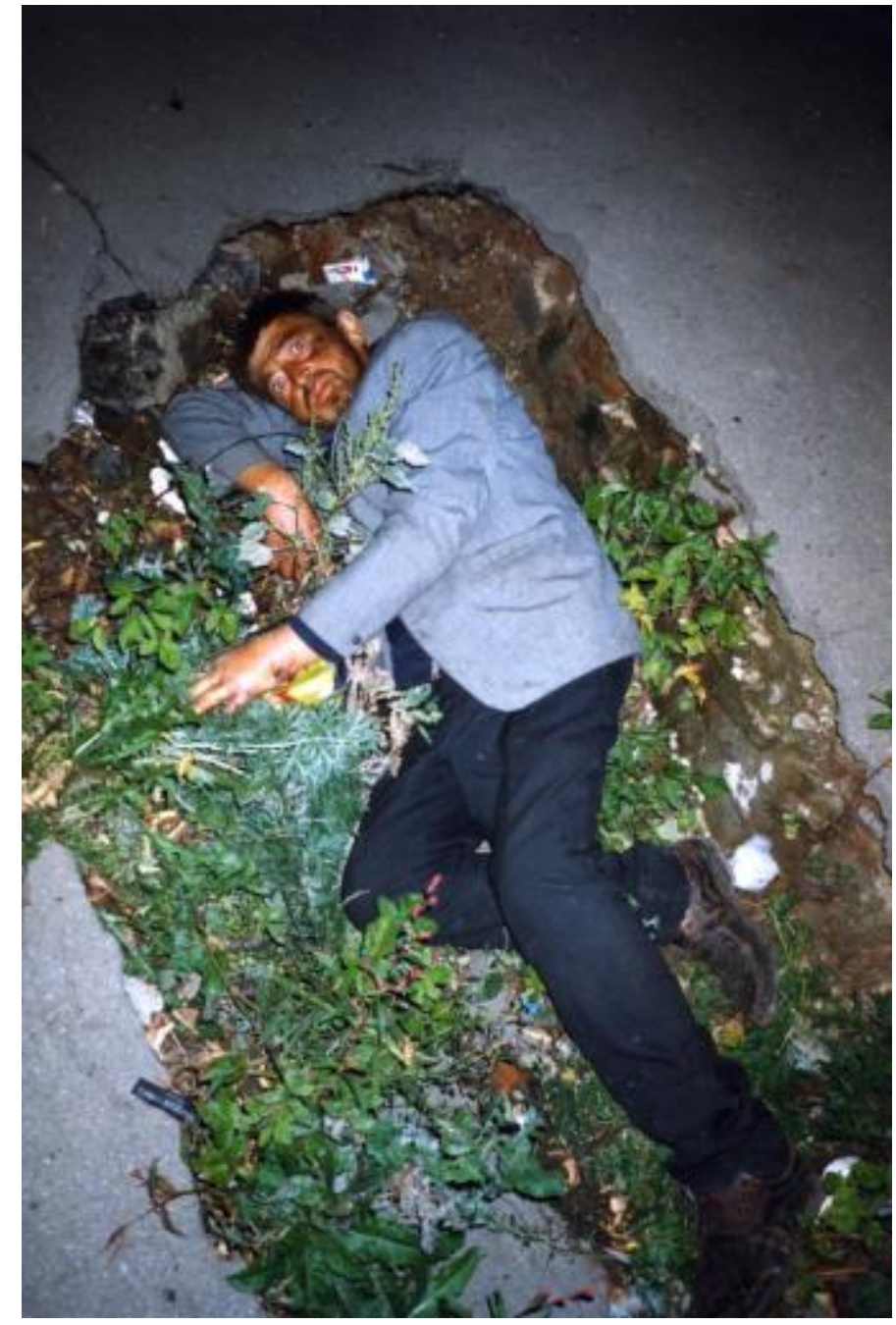

\section{Figure 1}

Boris Mikhailov, Untitled, from the series Case History, $1997-$ 98. Chromogenic color print, 58 $7 / 16 \times 393 / 16$ in. Copyright Boris Mikhailov; courtesy Pace/MacGill Gallery, New York.

\footnotetext{
${ }^{15}$ For more on Mikhailov's connection to Moscow Conceptualism, see Boris Groys's History Becomes Form: Moscow Conceptualism (Cambridge and London: MIT Press, 2010) and Matthew Jesse Jackson's The Experimental Group: Ilya Kabakov, Moscow Conceptualism, Soviet Avant-Gardes (C hicago: University of Chic ago Press, 2010).
} 
Although the focus of Case History is above all on Kharkov's inhabitants, the series clearly documents a city in decay. In some of the photographs, Mikhailov carefully aligns the two, as exemplified by the image of a man lying in a hole in an asphalt road (fig. 1). From its jagged, uneven shape, it is evident that the hole is not carefully designed, but rather the result of natural erosion or caused by rough weather conditions. Covered by plants and trash, the hole has clearly remained unattended for quite some time. The man is formally dressed, but his suit is stained and his shoes are worn. His hands are swollen and a large wound is visible on his left wrist. His face is covered in dust and grease. These visual markers suggest that the man is one of the homeless people in Kharkov. Mikhailov here captures both human and social decline and seems to suggest an almost symbiotic relationship between the homeless man and his environment-one may even speculate whether the man's positioning within the hole is accidental, or whether Mikhailov instructed the man how to lie. For example, his back and shoe bottom run parallel to the right edge of the asphalt, while small indents are visible in the asphalt above his head and above the elbow of the arm on which the man rests his head. He stretches his left arm out in front of his belly, perhaps to provide the spectator the best view of his swollen and wounded hand, an awkward pose that mirrors the irregular shape of the hole. In the upper left corner of the photograph, a large crack appears in the asphalt, and the direction of the crack continues visually through the position of the man's right forearm and the angle of his extended leg. Lastly, the man's jacket chromatically mirrors the asphalt, and his unwashed face has the color of the dirt and gravel in the hole. Considering these compositional features, it is as if Mikhailov suggests that man and environment are one, as if the hole has perfectly taken shape around the man's body. While Case History at first glance resembles social documentary photography in the vein of Jacob Riis, Walker Evans, Roman Vishniac, Mary Ellen Mark, and David Goldblatt (to name but a few), it is Mikhailov's careful compositional choices such as these that add a clear artistic component to the series, thus situating Case History as both documentary and fine-art photography. ${ }^{16}$

Documenting a specific moment in Ukrainian history, Mikhailov pays special attention to homeless subjects who are covered in wounds and characterized by deformities, as if their bodies bear physical evidence of a society in decline. Considering the focus on bodies in pain alongside the title of the series, the spectator is forced to look at the bodies portrayed as though extracted from a medical journal of pathology. This aspect of the work even led one critic to accuse Mikhailov of contributing to the creation of a "pornography of pain." 17 Although such characteristics point out the complicated issue of voyeurism and the photographer's potential exploitation of his/her subjects, I challenge the notion that Mikhailov's photographs are set on victimizing or humiliating the subjects whose wounded bodies are depicted.

In one photograph, Mikhailov portrays a naked woman with a large abdominal hernia-a physical ailment that causes pain and discomfort that may be increased by basic, everyday movements (fig. 2). The woman's naked body is centered in the photograph, and the woman

\footnotetext{
${ }^{16} \mathrm{O} n$ the connection between Mikhailov and documentary photography, see Walead Beshty, "Toward an Emphatic Resistance: Boris Mikhailov's Embodied Documents," Afterall: A Journal of Art, Context, and Enquiry, no. 12 (A utumn/Winter 2005), 80-88.

17 See Henry Hitchings, "What's Right in Front ofYou" in Times Literary Supplement, July 18, $2003,18$. The art critic and author Boris Groys has argued against s uch criticism, noting that on closer inspection, Case History "is in fact concerned with the mise-en-scène of the body-in this case not as an ideologically staged "Soviet" body, but as an erotic body expressing desire" in Groys, History Becomes Form: Moscow Conceptualism, 140 .
} 
stands tall, in profile, with a serious look upon her face. Her body, covered in sunlight, is aged and worn, and a large scar is visible on her shoulder. The woman's pose seems contrived and staged, suggesting that she is awa re of being photographed. The composition offers the spectator the best possible view of her deformity-exposed by the sun and set against a dark background. It is therefore tempting to argue that Mikhailov captured the woman in such a position so that the observer may get the best possible view of her deformity, satisfying our morbid fascination. However, a closer look at other formal, compositional decisions suggests that this is not simply an image of a hernia or a pathologized body. The woman's body is paralleled by the building structure behind her, as the brick walls are covered with wounds and architectural deformities, thereby evoking the marks that time leaves on everything and everyone. In some places paint is chipping off, and the wall to the right reveals a failed attempt to cover the brick in a different material. The beige color of the left wall is similar to the woman's general skin complexion, while the old paint stains mirror the darker shade of her nipples, her scars, and the mole above her right knee. The patterns in the mortar resemble the shapes made by the prominent veins in her hand, the creases in her elbow, and the wrinkles on her neck. Suddenly, the protruding hernia seems of less significance. Instead, in its detail and overall careful composition, the photograph becomes a celebration of lived life, imperfection, and naked vulnerability.

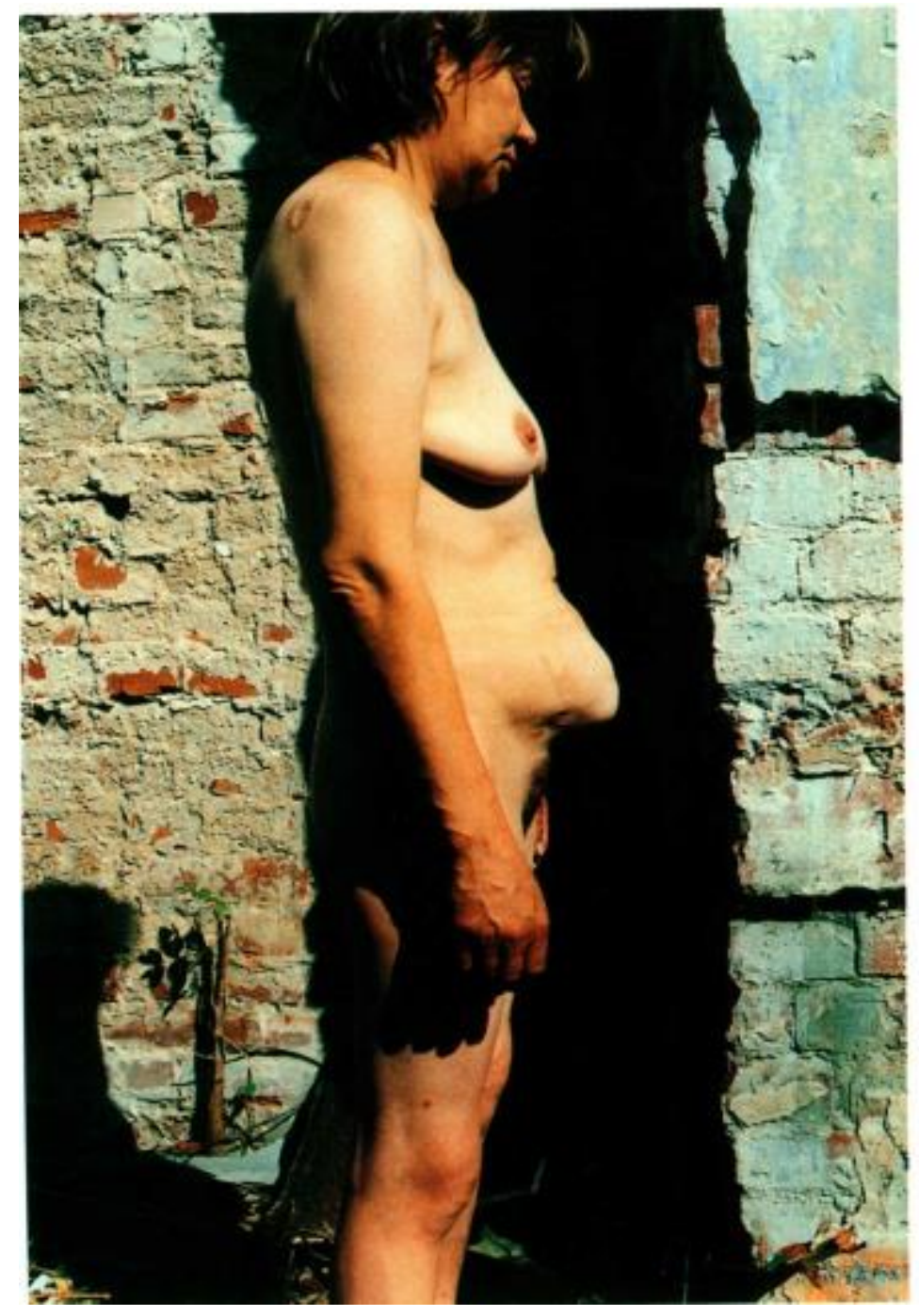

\section{Figure 2}

Boris Mikhailov, Untitled, from the series Case History (1997-98). Chromogenic color print, dimensions variable. Copyright Boris Mikhailov; courtesy Pace/MacGill Gallery, New York. 
What I am proposing by analyzing this specific photograph in form, content, and context, is that Mikhailov is not interested in exposing the wounds or deformities of others simply to shock or provoke the spectator. In Case History, the body in pain needs to be considered from a more generous approach that pushes us to look beyond the explicit exhibition of cuts and bruises, and that challenges us to view these bodies as worthy of aesthetic contemplation. More important, Mikhailov's compositional strategies compel viewers to look more closely and consider the stories of the individuals photographed in relationship to their surrounding environment. The homeless in Case History therefore should not be viewed simply as objects of a social documentary, but as co-creators in an a esthetic production. This latter point is made even clearer when examining the connection between the documentary and performance in Case History.

Commenting on the creative process of making Case History, Mikhailov states that he approached the homeless from a journalistic point of view, but that he wanted to avoid doing "pure journalism"-defined by the artist as "taking snapshots of events without interfering." ${ }^{18}$ He accomplished this by asking the homeless subjects to reenact situations or scenes he had witnessed, or to strike a pose of their own design. I claim that this should be interpreted as an act of embodied agency since Mikhailov's photographs do not solely document a specific historical moment; they also record the agency of Kharkov's homeless through their often self-fashioned portraits and reenactments. While I certainly do not propose viewing Case History as performance art, the staged elements of the works, and the complicit contribution of the homeless subjects who were asked to "perform themselves" should not be understated. Indeed, a continuum that may be traced in Mikhailov's photographs from the last three decades is his exploration of the fine line between theatrical performance (of everyday life) and documentary -an important aspect of his art that has been pointed out by several critics and is especially apparent in Case History. ${ }^{19}$

The implications of the homeless subjects' self-performance can be interpreted through Claire Bishop's concept of "delegated performance," defined as "the act of hiring nonprofessionals or specialists in other fields to undertake the job of being present and performing at a particular time and a particular place on behalf of the artist, and following his or her instructions. "20 The people who are hired, according to Bishop, are asked to perform their socioeconomic category, whether this is a matter of age, gender, race, disability, or profession. Mikhailov's accounts of the making of Case History focus on this element of collaboration between himself and the homeless, but it should be noted that he paid the

\footnotetext{
${ }^{18}$ Boris Mikhailov and Jan Kaila, "A Discussion between Boris Mikhailov and Jan Kaila" in Boris Mikhailov: The Has selblad Award 2000, ed. Gunilla Knape (Goteborg: Hasselblad Center, 2000), 78 -84.

${ }^{19}$ Viktor Misiano and A nna Pilkington give a valuable account of this connection in Mikhailov's work, coining it "the representation of the everyday and the performative acting -out of subjects." See Misiano and Pilkington, "The Ethics of View: Notes on Boris Mikhailov," Afterall: A Journal of Art, Context, and Enquiry, no. 72 (Fall/Winter 2005): 72 -79. A nne von der Heiden also argues that the connection between the documentary and the performative is at the very core of Case History, and calls it "the most scandalous element of the work as a whole." See von der Heiden,"'Consummatum Est' Case History by Boris Mikhailov" in Boris Mikhailov: A retrospective/Eine Retrospektive, ed. Urs Stahel (Zurich: Scalo, 2003), 170-172.

${ }^{20}$ Claire Bishop, "Delegated Performance: O utsourcing Authenticity," October 140 (Spring 2012): 91.
} 


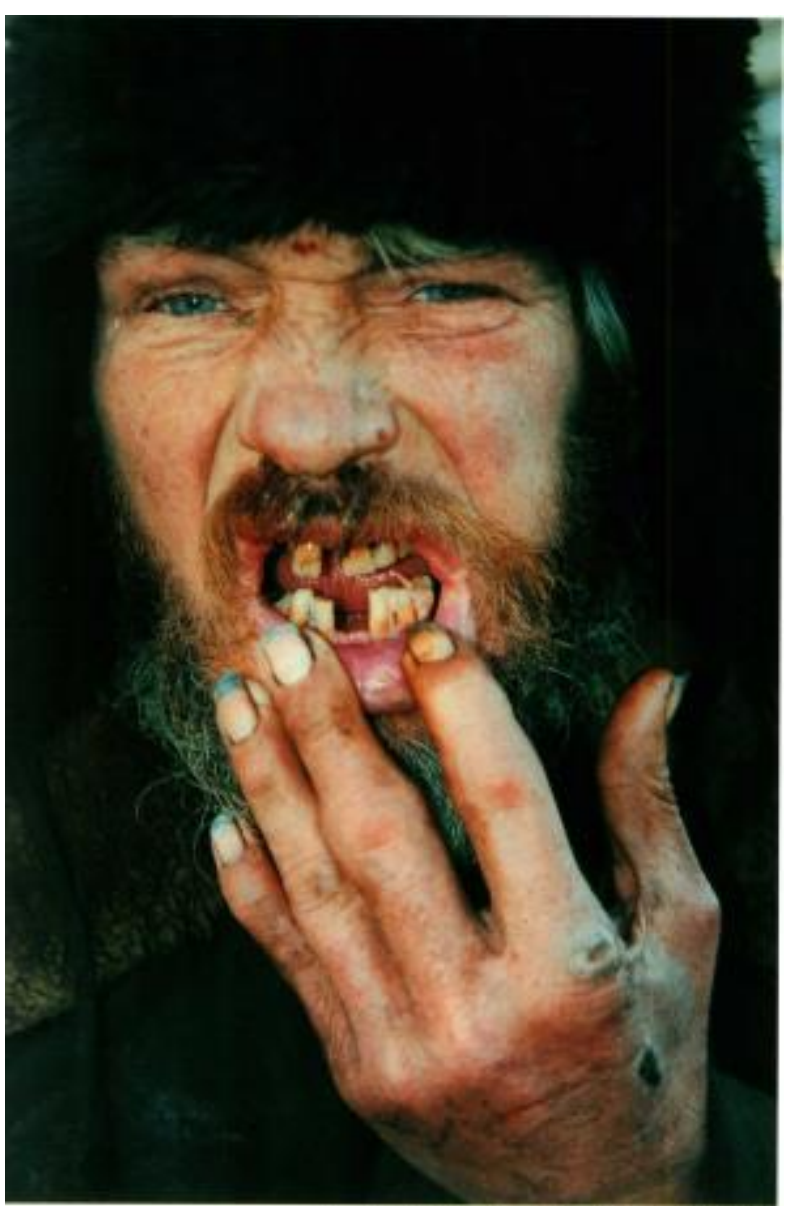

\section{Figure 3}

Boris Mikhailov, Untitled, from the series Case History (1997-98). Chromogenic color print, dimensions variable. Copyright Boris Mikhailov; courtesy Pace/MacGill Gallery, New York.

homeless for their participation. ${ }^{21}$ To some degree, this establishes an unequal power relation between Mikhailov and the homeless, making it easy to criticize the photographer for exploiting a vulnerable social group. But although such a transaction may affirm the artist's hierarchical status, it is also a matter of probing singular authorship, delegating power, and entrusting the performers with agency. ${ }^{22}$ There is a dialogical relation between artist and performer; as Bishop emphasizes, "delegation is not just a one-way, downward gesture." 23 To interpret the wounded bodies in Case History as exploited subjects who are taken advantage of deprives the homeless individuals of the agency that is manifest in their participation. To be clear, I am not suggesting that the homeless in Case History are fully in

\footnotetext{
${ }^{21}$ In the introductory notes to Case History, Mikhailov discusses the fact that he paid the homeless to participate in the making of the series: "Manipulating with money is somehow new way of legal relations in all areas of the former USSR. And by this book I wanted to transmit the feeling that in that place and now people can be openly manipulated. In order to give this flavour of time I wanted to copy or perform the same relations which exist in society between a model and myself." In Boris Mikhailov, Case History (Berlin: Scalo, 1999), 9. The financial transaction between Mikhailov and his photographic subjects thus draws awareness to the capitalist system at large, and also speaks to the situation of post-Soviet U kraine in the 1990 s, during which time certain groups gained pros perity, while others faced the deepest poverty.

22 Bishop, "Delegated Performance," 110.

23 Ibid., 111 .
} 
charge of the work's production and its distribution, but rather that agency should not be reduced to thinking of the photographic subjects as exploited, and the artist as exploiter. Instead, the individuals in the series must be acknowledged for their participation in the making of the photographs. An old man who opens his mouth to reveal his missing teeth, pulling back his lip so we can see them better, surely displays an image of someone's pain and misfortune, but it is also the image of an individual who allowed for such a photograph to be taken (fig. 3). The old man looks straight into the camera as if to tell us that he is not ashamed of his pain, suggesting that being photographed in this setting is a matter of consensus, agreement, and mutual recognition between the photographer and the subject, although this naturally does not do anything to ease his personal tragedy. The confrontational gaze and the matter-of-factness with which the homeless man presents himself affirm his agency. Ignoring such an expression of personal agency, I argue, may lead to the further victimization of the photographic subject.

My intention so far has been to show how Mikhailov combines documentary photography, fine art, and performance in order to record a specific moment in post-Soviet history. In addition, Mikhailov's Case History presents bodies in pain that are not victimized or robbed of agency, but are rather active participants in the creative process of making the series. Nevertheless, in Case History, bodily pain as such is portrayed by Mikhailov as a consequence of social issues beyond the subject's control. What, then, of pain that is selfinflicted and consciously incorporated into artistic action?

\section{Petr Pavlensky: The Political Potential of Pain}

In November of 2013, news agencies across the world circulated an image of a young man sitting naked on Red Square in front of the imposing Kremlin in Moscow with his scrotum nailed to the cobblestones (fig. 4). The young man was Petr Pavlensky, a professionally trained artist who sees his practice as uniting art and political action, and who in the last five years has emerged as a powerful voice of dissent in Russia. ${ }^{24}$ Besides being mentioned in news reportage around the world, the persistent coverage of Pavlensky in magazines such as Artforum, the Calvert Journal, and 1843 (the Economist's cultural magazine) has made Pavlensky a symbol of Russian art and activism in the eyes of a Western audience. The wide online distribution of Pavlensky's actions and the resulting commentaries triggered by them further speak to the charged relationship between his performances and their documentation, and also raise the question of whether the public aftermath of his actions should, in fact, be interpreted as being part of his overall performance. In the following descriptions, I refer to live performances-events that happened at a certain time and place in front of an audience-but my descriptions are necessarily based on photographs taken during the events. On the one hand, this represents

\footnotetext{
${ }^{24}$ Petr Pavlensky is a former student of both Saint Petersburg Art and Industry Academy and Saint Petersburg PRO ARTE Foundation for Culture and A rts (which he quit for political reasons). Together with O ks ana Shalygina, he is the founder of the journal Political Propaganda, which publishes material in different media on art and politics. While Pavlensky's art does not always revolve around self-mutilation and a public display of the artist's own (naked) body, the works that will be explored here all focus on the wounded body in encounter with public spaces and political power. It should also be noted that, when referring to his performances, Pavlensky us es the Russian word акция (aktsiya). This term should be understood as an act that is the consequence of actionis $m$. By employing this word to describe his art, Pavlensky positions himself within the larger artistic tradition and dis course of V iennese A ctionism of the 1960 s and 1970s, but more important, it connects him to Moscow A ctionism of the 1990s, famous ly pers onified by figures such as A natoly Osmolovsky, A leksandr Brener, and Oleg Kulik. For the sake of simplicity, I will use the English word action when describing Pavlensky's performances.
} 
a methodological challenge, and on the other, it offers a chance to approach Pavlensky's work as twofold: as both performance and as photographic performance documentation, circulated not as art but as news. To each of the performances that will be discussed in my paper, Pavlensky invited photographers to document his actions, although no contract existed between the artist and the photographers regarding the future media distribution of the images. ${ }^{25}$ Thus, Pavlensky did not view the photographs as being part of the artwork. Rather, he used photography to validate and document his performances.

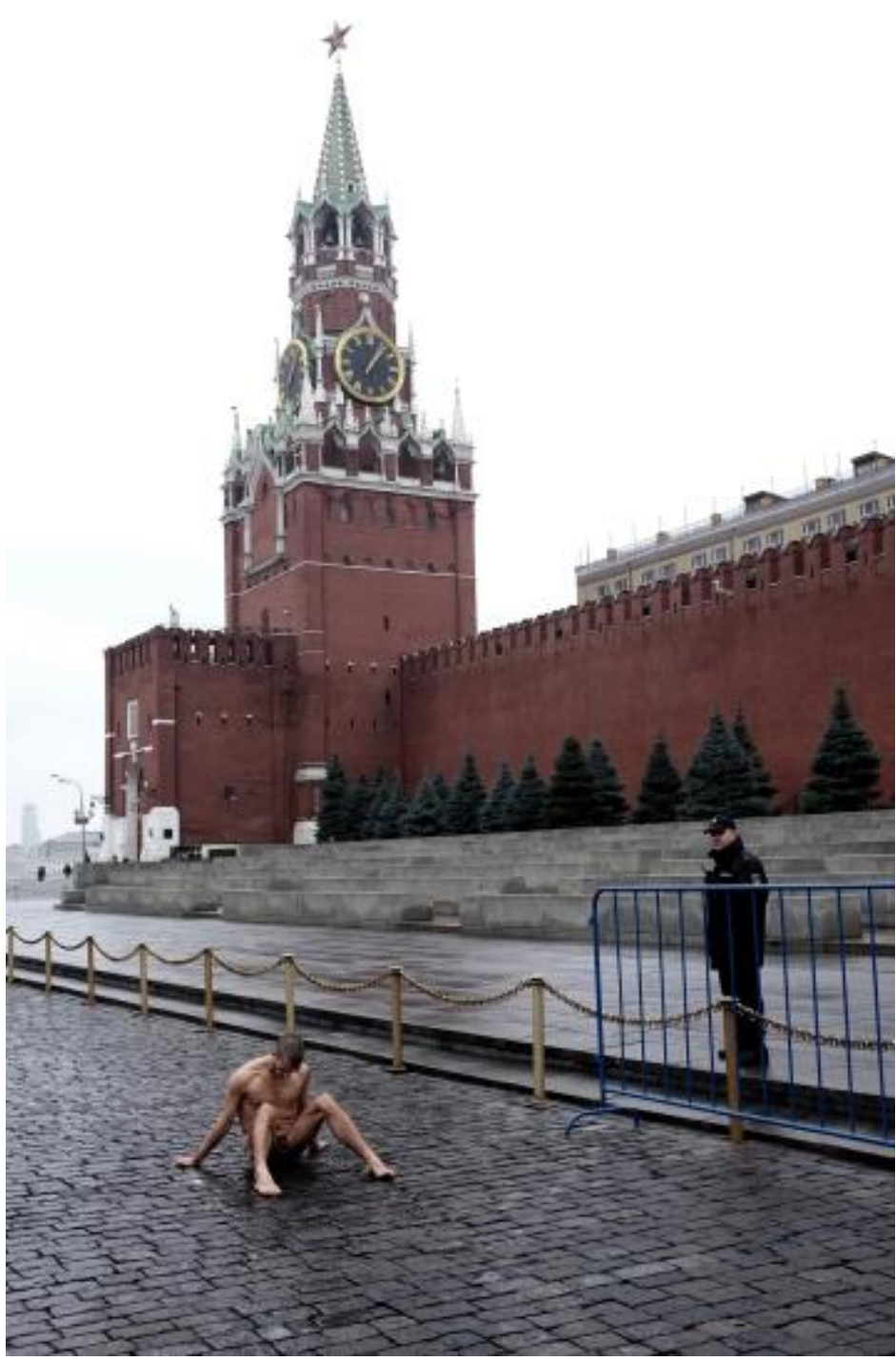

\section{Figure 4}

Petr Pavlensky, Fixation (Фиксация), November 10, 2013. Performance action with photographic documentation, Moscow, Russia. Photograph, $36.39 \mathrm{x}$ 56.31 in. Photographer anonymous, image courtesy of Petr Pavlensky.

${ }^{25}$ Pavlensky in an email to the author, September 4,2016. 
Paul Auslander has argued that whenever a performance is documented, the performance may be approached as raw material for documentation, while the document itself emerges as the final product that is widely circulated and known to a larger audience. ${ }^{26}$ In a similar vein, Amelia Jones states that performance art is dependent on documentation "to attain symbolic status within the realm of culture." 27 In Pavlensky's case, this is especially true. Not only does the distributed documentation reach an additional audience both nationally and internationally, but it also helps constitute his actions as art: for, as Auslander claims, "the art of documenting an event as performance is what constitutes it as such." ${ }^{28}$ In the Russian political context in which Pavlensky operates, such an attribution is of crucial importance. His actions have been interpreted by the authorities as signs of mental illness and as acts of vandalism, and as a result Pavlensky has been detained, fined, and imprisoned. Furthermore, the iconic photographs of his actions may become part of a collective memory of a body that resisted political oppression. The relationship between Pavlensky's actions and their documentation is therefore "viral" in the sense that Christopher Bedford deploys the term, precisely because the afterlife of his performances "extends the primary act of the performance into the indefinite future of reproduction." 29

Although the action on Red Square was not the first time Pavlensky used his own body to express his opposition to the political situation in Russia, Fixation (Фиксация) received massive media attention due to its explicit content and loaded symbolism: the date of the action, November 10, coincided with the national Police Day, and Red Square bears special significance in the political history of the Russian state. ${ }^{30}$ Regarding what he wanted to achieve with the performance, Pavlensky stated:

The performance can be seen as a metaphor of the apathy, the political indifference, and the fatalism of Russian society. It is not the official lawlessness that deprives society of the possibility to act, but the fixation on its defeats and

\footnotetext{
${ }^{26}$ Paul A uslander, "The Performativity of Performance Documentation" in PAJ: A Journal of Performance and Art 28, no. 3 (2006): 3.

${ }^{27}$ A melia Jones, "'P resence' in A bs entia: Experiencing Performance as Documentation" in Art Journal 56, no. 4 (1997): 13.

${ }^{28}$ A uslander, "Performativity of Performance," 5 .

${ }^{29}$ Christopher Bedford, "The Viral O ntology of Performance" in Perform, Repeat, Record: Live Art in History, eds. A melia Jones and A drian Heathfield (Chicago: Intellect Books, 2012), 77.

30 Police Day-or Police and Internal A ffairs Servicemen's Day-is a professional holiday in Rus sia. It has been celebrated since 1962 and is formerly known as Militsiya Day. O $n$ this day, the police and everyone working in the Ministry of Internal A ffairs are honored by their superiors and o ther government officials. Red Square dates from the late 15 th century. For centuries, it functioned as one of the most central market places in Moscow, and was a gathering place for public celebrations and castigations. Red Square is also the location for Russia's famous military parades. It should be noted that Pavlensky's action evokes another historical component: in Russian prisons, there is a tradition of inmates nailing their scrotums to stools and benches to protest the pris on authorities. See interview with Marat Guelman in Ekow Es hun, et. al., "The Naked Truth: the A rt World Reacts to Pyotr Pavlensky's Red Square Protest," Calvert Journal, November 14, 2013 , http://calvertjournal.com/articles/show/1768/pyotr-pavlensky-russian-artist-nailsred-square.
} 
losses nails us even firmer to the pavement of the Kremlin, shaping people into an army of apathetic statues-patiently awaiting their fate. ${ }^{31}$

Pavlensky's statement touches upon a number of characteristic elements of his work: its almost obvious use of metaphors and symbolism; its clear political component; and its desire to comment on the larger social body through the use of the artist's own body. The likening of the Russian people to "an army of apathetic statues" is telling of how Pavlensky views his contemporaries: as passive and submissive; easily shaped by the authorities; and as unwilling or incapable of changing their fates. ${ }^{32}$ Nevertheless, the use of the word "army" suggests that Pavlensky acknowledges the potential power and inherent agency of Russia's citizens, and although Pavlensky is physically affixed to the square in his performance, the fixation alluded to in the title is also psychological in nature. I therefore argue that Pavlensky's actions do not only reflect the artist's interpretation of his contemporaneity, but they also call on others to act, even if indirectly. The way in which Pavlensky speaks to today's Russia, while simultaneously anchoring his actions in Russian history through his careful choice of performance locations and timing, makes his actions function as a reminder: history may be irreversible, but it should not dictate our present. This, of course, does not mean that Pavlensky's actions do not need to be contextualized within their own socio-historical moment to be fully understood.

Following the parliamentary election of December 2011, in which Vladimir Putin's party United Russia won the majority of the seats in the Duma, protests broke out in several cities around the country. For months to come, people regularly gathered in the streets to protest what they considered illicit elections and political and economic corruption - signs of Russia moving in a non-democratic direction. On February 21, 2012, five members of the punk rock collective Pussy Riot staged a performance of their song "Punk Prayer-Mother of God, Chase Putin Away!" in Moscow's Cathedral of Christ the Savior. ${ }^{33}$ The video of the performance was uploaded to the Internet and soon went viral, and with their bright costumes and radical message, Pussy Riot became a world symbol of the anti-Putin opposition in Russia. However,

\footnotetext{
31 "А кцию можно рассматривать как метафору апатии, политической индифферентности и фатализма современного российского общества. Не чиновничий беспредел лишает общество возможности действовать, а фиксация на своих поражениях и потерях все крепче прибивает нас к кремлевской брусчатке, создавая из людей армию апатичных истуканов, терпеливо ждущих своей участи." A uthor's translation. See, "Художник Петр Павленский прибил мошонкугвоздем к брусчатке на Красной площади," November 10, 20 13, http://grani.ru/Politics/Russia/activism/m.221013.html.

${ }^{32}$ A rt critic Marat Guelman for instance interpreted Fixation as a means of showing society and the opposition "that we have lost, that the battle is over: they've imprisoned us all and nailed us to the ground." Guelman even added that Pavlensky's action was "the artistic equivalent of setting yourself on fire," while the Russian artist O leg Kulikviewed Pavlensky as a martyr. See Eshun, et al.

33 Pussy Riot's choice of location is by no means coincidental. The original Cathedral of Christ the Savior was built in the 19 th century, but, on the order of Joseph Stalin, it was demolished in 1931. In 1958, a large outdoor swimming pool was built on the foundation of what was initially supposed to become the Palace of the Soviets. The pool operated until 1994, and in the following year, the building of the new cathedral began. The second Cathedral of C hrist the Savior was consecrated in A ugust 2000 . Eliot Borenstein has argued that the $\mathrm{C}$ athedral of $\mathrm{C}$ hrist the Savior must be unders tood as "the material foundation of the cultural logic of P ussy Riot" because it speaks to the concept of historicalinstability. Pussy Riot's performance must therefore be unders tood as a strong critique against the almostsymbiotic relationship between the Russian state and the Russian Orthodox Church - a connection that was made explicitly evident in the months preceding the Russian presidential election of 2012 when Patriarch Kirill in his sermons encouraged people to vote for Putin. See Eliot Borenstein, "Holy Appropriate: Why Pussy Riot and the Cathedral of C hrist the Savior Are a Match Made in Heaven," Calvert Journal, January 22, 2012, http://calvertjournal.com/comment/show/1 983/christ-the-saviour-moscow-pussy-riot.
} 
the severe legal persecutions facing the women also made clear how harshly the Russian state would punish political dissidents. ${ }^{34}$

Pavlensky's action Seam (Шов) of July 2012, was in indirect dialogue with Pussy Riot and the authority's treatment of the group's members. Standing in front of the famous Kazan Cathedral in St. Petersburg, dressed in black and with a stoic expression, Pavlensky held a large placard which read: "The performance of Pussy Riot was a replication of the famous action of Jesus Christ (Matthew 21:12-13)1/35-referring to Jesus Christ's expulsion of money changers and merchants from the Temple. ${ }^{36}$ In contrast, the artist's silence was made explicit and irreversible since his mouth was sewed shut with visible red thread. ${ }^{37}$ Pavlensky's action thus expressed his support for the members of Pussy Riot, whose trial was to take place in Moscow the same month. ${ }^{38}$

A year later, in May 2013, Pavlensky would once more use his body to address the political situation in Russia. In the action Carcass (Туша), Pavlensky lay in front of the main entrance of the St. Petersburg Legislative Assembly bare naked and wrapped inside a large cocoon of barbed wire (fig. 5). As the barbed wire would cut deeper into the artist's skin with every move he made, Pavlensky was forced to lie completely still in the cold, incapacitated and dependent on law enforcement to be released. Carcass was performed as a protest against a number of laws that were discussed (and passed) in the Russian Duma in the fall of 2012 and spring of 2013, several of which Pavlensky and others interpreted as restricting individual freedom. ${ }^{39}$ Pavlensky wished to embody this restriction, and to symbolize "the existence of a person living within a repressive yet law-given system in which every move

${ }^{34}$ For more on the aftermath of Pussy Riot's performance, see Masha Gessen, Words Will Break Cement: The Passion of Pussy Riot (New York: Penguin, 2014).

35 "А кция Pussy Riot была переигрыванием знаменитой акции Иисуса Христа (М ф. $21: 12$-13)." A uthor's translation.

36 The citation from Matthew $21: 12-3$ reads: "And Jesus went into the temple of God, and cast out all them that sold and bought in the temple, and overthrew the tables of the moneychangers, and the seats of them that sold doves, And said unto them, It is written, My house shall be called the house of prayer; but ye have made it a den of thieves." Pavlensky underlines the symbolical gesture of Pussy Riot's performance, as the officials of the Russian Orthodox Church are likened to the moneychangers in the Temple because of their commercialactivities. For more on the Russian Orthodox Church and its economic relations, see Nikolai Mitrokhin's Русская православная церковь: современное состояние и актуальные проблемы (Moscow: Novoe literaturnoe obozrenie, 2004).

${ }^{37}$ For images and a survey of his actions, see Shaun Walker, "Petr Pavlensky: Why I Nailed my Scrotum to Red Square," The Guardian, February 5, 2014, https://www.theguardian.com/.

${ }^{38}$ Although clearly s peaking to his present, Pavlensky's choice of action also situated him within a larger corpus of both performance artists and activists who have sewed their mouths shut to signal political oppression and the silencing of certain social groups. David Wojnarowicz, Bob Flanagan and Sheree Rose, and Ron A they are just a handful of the artis ts who have had their lips sewn shut during or as performances for diverse reasons, but the gesture further res onates with those of asylum seekers in A ustralia and Great Britain as a way of symbolizing unjust governmental treatment. See Amelia Jones, "Performing the Wounded Body: Pain, A ffect, and the Radical Relationality of Meaning," Parallax 15 no. 4 (2009): 46-47.

39 O ne such example is the Russian Federation's law "for the Purpose of Protecting Children from Information A dvocating for a Denial of Traditional Family Values," which became known in Western media as the "gay propaganda law." A nother, the law "O n A mendments to Legislative Acts of the Russian Federation regarding the Regulation of the A c tivities of $\mathrm{N}$ on - profit O rganisations Performing the Functions of a Foreign A gent," stated that Russian NGOs receiving donations from abroad must officially declare themselves as foreign agents, and that all "political activity" within a given organization must be registered with the authorities before being carried out. 
triggers a strong reaction by the law, and forces its way into the body of the individual. "40 The title of Carcass further suggests that Pavlensky's body should be seen as immobilized and deprived of agency. The performance therefore exhibited the artist's body as willingly victimized as Pavlensky indirectly delegated some of his initial artistic agency to the people who witnessed his action, and to the ones who cut him out of the barbed wire-a point that will be explored more closely below.

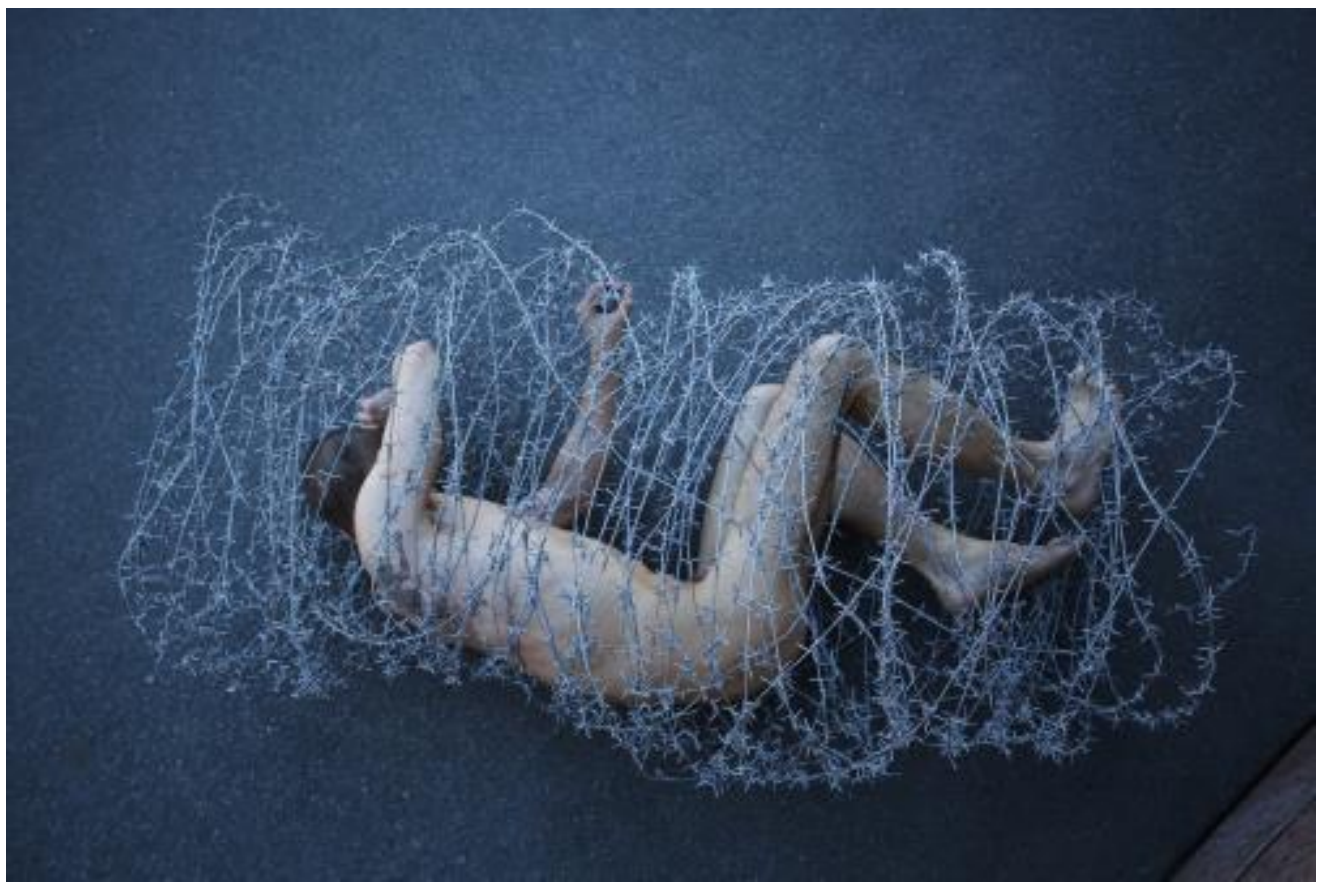

Figure 5

Petr Pavlensky, Carcass (Tyшa), May 3, 2013. Performance action with photographic doc umentation, St. Petersburg, Rus sia. P hotograph, $24 \times 16$ in. P hotographer anonymous, image courtesy of Petr Pavlensky.

As a consequence of his actions, Pavlensky's mental state has been questioned, and the artist has been evaluated by state-appointed doctors and psychiatrists. One might say that the authorities had no choice-exposing or voluntarily seeking out pain goes a gainst social norms, and is usually synonymous with destructive behavior. Pavlensky is well aware of this, which can partially explain the location of his (to the date of this publication) last performance involving his wounded body. The action Segregation (Отделение) took place outside the Serbsky Center, a famous psychiatric hospital in Moscow. ${ }^{41}$ On October 19, 2014, Pavlensky sat naked on the wall outside of the Serbsky Center, and with his only accessory,

\footnotetext{
40 "существование человека в репрессивной законодательной системе, где любое движение вызывает жестокую реакцию закона, впивающегося в тело индивида." A uthor's translation. See "Художник Петр Павленский прибил мошонку гвоздем к брусчатке на Красной площади," November 10, 2013, http://grani.ru/Politics/Russia/activism/m.221013.html.

${ }^{41}$ In the Soviet U nion, punitive psychiatry was a common way of silencing artistic or political dissensus, thus diagnosing opposition as a mental illness. For more on the topic, see for instance Sarah Marks and Mat Savelli, eds., Ps ychiatry in Communist Europe (London: Palgrave Macmillan, 2015), and Rebecca Reich, "Inside the Psychiatric Word: Diagnosis and Self-Definition in the Late Soviet Period," Slavic Review 73, no.3 (2014): 563-84.
} 
an enormous knife, cut off his right earlobe (fig. 6). By consciously performing an action that he knew would likely label him as psychologically unstable, Pavlensky challenged the carefully crafted distinction between the sane and the insane, which separates the healthy from the sick. Moreover, by physically cutting off his earlobe (which seems to have disappeared when Pavlensky was escorted away from the Serbsky Center ${ }^{42}$ ) from the rest of his body, Pavlensky gestured towards the fragile line of demarcation between the part and the whole; the individual and the state. He also evoked the trope of the misunderstood artist-genius-balancing between madness and prophetic clarity, and famously personified by van Gogh and his severed ear. ${ }^{43}$ It is thus the act of cutting as such that is important in Pavlensky's action, not the physical mutilation of his body.

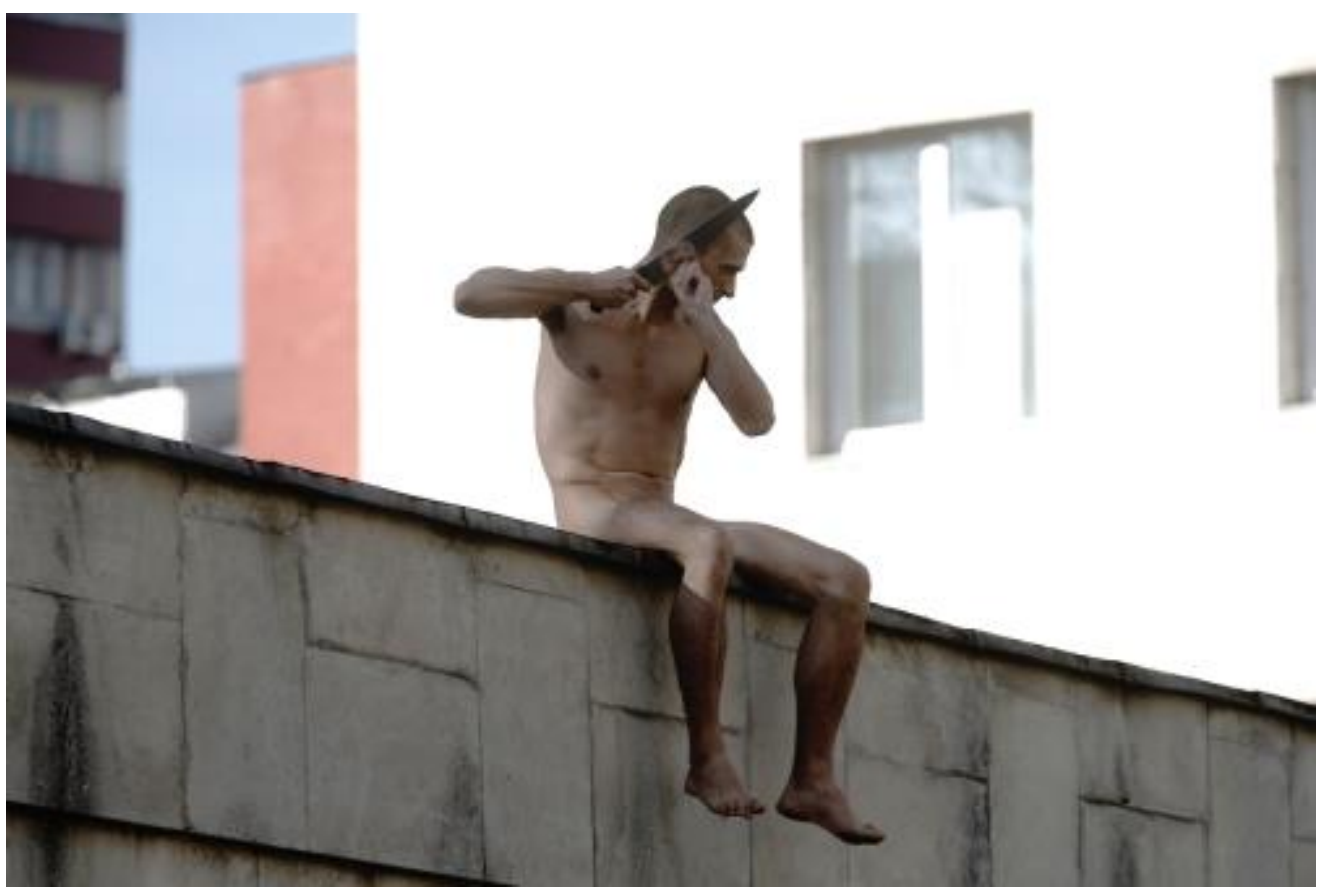

Figure 6

Petr Pavlensky, Segregation (Отделение), O ctober 19, 2014. Performance action with photographic documentation, Moscow, Russia. Photograph, $72 \times 48$ in. Photographer anonymous, image courtesy of Petr Pavlensky.

\footnotetext{
42 Marc Bennetts, "Acts of Resistance: Pyotr Pavlensky on Performance A rt as Protest," the Calvert Journal, December 1, 2014 , http://calvertjournal.com/articles/show/3373/pavlensky-performance-artprotest.

43 Several commentators have connected Pavlensky to the figure of the Holy Fool (юродивый). Тhe Holy Fool has deep roots in Russian O rthodoxy where the term designates someone who feigns stupidity or madness in order to uncover injustice. The figure also appears frequently in Russian literature. For more on Pavlensky as an example of the Holy Fool, see for instance Dasha Filippova, "The Russian Terrorist: Petr Pavlensky," ArtSlant, June 13,2016, http://www.artslant.com/9/articles/show/46065\#f4. It should be noted, however, that the artist hims elf has rejected such a comparison: see his interview in Новая газета in December 2012, http://www.novayagazeta.ru/arts/71111.html.
} 
Simply focusing on Palvensky's own body leaves out an important component of his art: the relationship between the social body and the body of an individual, an essential aspect of his work because of its consciously and explicitly public nature. Discussing the performance Carcass in which the artist becomes completely dependent on others to be freed, Pav lensky actively engages with the question of why his performances are so centered on his own body: "Why I use the body? Because there is a social body -a body that I am also a part of. By using my own body in this act, I am showing what is going on with the social body." 44 If we take him at his word, Pavlensky does not conceive of his actions as disconnected from the lives of his Russian contemporaries, but rather seeks to reflect what he considers the state of the social body. Pavlensky's view on the artist's body here clearly resonates with the projects of other body artists who see the artistic subject as a subject that continuously reaches beyond itself in order to show that identity is always relational, thereby entering the aesthetic realm as a social and political entity. ${ }^{45}$ In addition, the performed link between the individual and the social body in Pavlensky's actions makes it especially valid to analyze his approach to pain and to ask whose pain this really is. If Pavlensky's body is a metaphor for the larger social body, one may assume that he considers the social body in pain, perhaps even to be pitied or healed. And yet, despite Pavlensky's powerful use of metaphors, such metaphors do not obliterate the fact that, during his actions, the body in pain is indeed his. This raises an important issue regarding his actions: are we (as spectators and as representatives of the social body) somehow to blame for the individual's suffering? ${ }^{46}$ Regardless of how one chooses to answer, the question itself shows the importance and potential of paying special attention to pain in Pavlensky's actions. ${ }^{47} \mathrm{I}$ argue that, due to the artist's blurring of the border between the private and the social body, the experience of pain

44 RussiaForAll. "Художник Пётр Павленский о своей акции у ЗА КС СПБ," Y ouTube Video, $3: 41$, May 8 , 2013, https://www.youtube.com/watch? v=YIWAWObrShE. A uthor's translation.

${ }^{45}$ A melia Jones, Body Art/Performing the Subject (Minneapolis/London: U niversity of Minnesota Press, 1998), 13-14. See also Zdenka Badovinac, ed., Body and the East: From the 1960s to the Present (C ambridge, MA: M IT Press, 1999); Michael Feher, "O fBodies and T echnologies" in Discussions in Contemporary Culture, ed. Hal Foster (Seattle: Bay Press, 1981); and Nelly Richard, "Margins and Institutions: A rt in Chile since 1974," in Art \& Text 21 (1986). For a specific account of body art and its social significance in relation to masochism in Western performance art, see Kathy O 'Dell, Contract with the Skin: Masochism, Performance Art, and the 1970's (Minneapolis: University of Minnesota Press, 1998).

46 This question brings to mind other performances by artists such as Chris Burden, Gina Pane, and Marina A bramovic-artists who have all self-inflicted pain or had others inflict pain upon their bodies. For an analys is of the "silent acceptance" of audience members to such acts, see O'Dell, Contract with the Skin; and Frazer Ward, No Innocent Bystanders: Performance Art and Audience (Hanover, Dartmouth College Press, 2012).

47 This is not to say, of course, that Pavlensky's actions are about pain as such. When asked about the role of pain in an interview, Pavlensky stated: "It is not important. In my actions I do not attach any conceptual significance to pain, and I do not emphasize it. The point is not to bring harm upon myself. In general, I relate to pain as I relate to a phobia that must be overcome-like any other fear. The feeling of pain originates in the mind." A uthor's translation. For the original quote in Russian, see Evgeniy Levkovich, "Пётр Павленский: 'Моя цель-побудить людей к действию'," Julia\&Winston, November 9 , 2015 , http://juliawinston.eu/pavlensky/. While Pavlensky seems to want to draw attention away from pain as a component in his actions, I maintain that, to the average viewer, the as sumed presence of pain still affects how one reacts to and interprets his actions. 
must be considered as both private and social in nature: the pain of another is also my own; the pain inflicted by another, is also inflicted by me. ${ }^{48}$

\section{Pain Rendered Public}

As should be clear from what has been explored so far, Mikhailov and Pavlensky are not necessarily interested in simply focusing on the pain of one single individual; rather, they use the wounded body to allude to the larger social and political structures that may be causing pain. For both artists, the distinction between the individual and the social body is thereby challenged. Because of this, I would like to suggest that the presence of pain in the artworks discussed above indirectly disputes Elaine Scarry's study The Body in Pain, in which she argues that pain is inexpressible; that it resists language and is characterized by its inability to be shared. As Scarry puts it, "[t]o have pain is to have certainty; to hear about pain is to have doubt." 49 Pain, for Scarry, cuts us off from our community and the ability to sufficiently express our emotions, and threatens to destroy our sense of self in the world: our ethics, the promises given by us to loved ones, and our personal integrity. Scarry approaches pain as an experience of pure negation; pain as something always appearing as being against the subject, even though the sensation of pain introduces a sense of radical subjectivity. ${ }^{50}$

Scarry's work has been influential across disciplines, but it has also been criticized for giving an ahistorical account of pain, in which pain is presented as an ontological entity of its own-independent of cultural and political signifiers. Pain becomes a fact for Scarry, rather than something that needs to be interpreted within a more complex framework. ${ }^{51}$ Historian Joanna Bourke offers an alternative approach and seeks to contextualize pain as a concept and to challenge the notion of it being entirely private in nature. Bourke points out that pain can be felt differently depending on how one experiences it, and should be analyzed as a type of event rendered public through language-not as something that happens to the body independently of its environment. ${ }^{52}$ As Bourke phrases it, "pain describes the way we experience something not what is experienced," and this "way" of experiencing pain is

\footnotetext{
48 Jennifer Doyle's scholarship has explored the importance of the viewer's affective response to artworks of challenging or difficult content. Specifically writing on the "difficulty" involved in viewing the performances of the HIV-positive body artist Ron A they, Doyle notes: "The work is hard because it forces us to keep company with vulnerability, intimacy, and desire. . . These are the things that, in fact, make life hard. They are productive and important kinds of difficulty - not because they expand our ideas of what constitutes Art but because they speak to quite fundamental as pects of being a social subject." Doyle's book is especially useful when interpreting the use of the wounded body in Case History and in Pavlensky's actions, as she argues that the artist's triggering of an affective response in the viewer establishes or further strengthens the political and ideological implications of a given artwork, thus making us aware of our own responsiveness and potential to act. See Doyle, Hold It Against Me: Difficulty and Emotion in Contemporary Art (Durham, NC: Duke University Press, 2013 ), 20.

49 Elaine Scarry, The Body in Pain: The Making and Unmaking of the World (Oxford: Oxford University Press, 1985), 13 .

50 Ibid., 50 .

${ }^{51}$ Geoffrey Galt Harpham, "Elaine Scarry and the Dream of Pain," Salmagundi no. 130-131: 208.

52 Joanna Bourke, The Story of Pain: From Prayers to Painkillers (O xford: O xford University Press, 2014).
} 
intrinsically public and political in nature. ${ }^{53}$ Bourke argues that by scrutinizing various painevents from a political perspective, "we are encouraged to explore the political apparatus . . . of pain-events: the discourses, institutions, laws, and medical, scientific, historical, and philosophical structures that underpin knowledges and be haviours associated with being-inpain." 54 However, Bourke states, although our experience of pain might be connected to larger systems of power (ideology, the state, the police, etc.), this does not mean that individuals are unable to reconstruct pain-events that may oppose them. The pain-event as a mode of opposition is, I argue, exactly what is being exhibited in Case History and Pavlensky's actions.

Bourke is a helpful interlocutor for understanding the role of pain in the works of both Mikhailov and Pavlensky because she focuses on the public component of pain. In my reading, the wounded body should here be seen as a body that is already incorporated in and marked by external forces that cause pain. Both artists therefore speak to the body's vulnerability-a topic that has gained a prominent position in Judith Butler's scholarship of the last decade. Butler has convincingly argued that the body is susceptible to external forces, although this does not mean that it is simply a surface for others to inscribe.$^{55}$ Vulnerability does not speak to a subject's personal disposition but must be regarded as inherently relational, as an inescapable result of our human condition of living amongst others. ${ }^{56}$ In recent work, Butler pays special attention to forms of political resistance that mobilize the fragility of the human body, with the goal of asserting existence through deliberate bodily exposure. ${ }^{57}$ Arguably present in Case History as well, this form of political resistance is especially apparent in Pavlensky's actions and adds another level of complexity to his use of pain as a mode of artistic expression. Pavlensky's physical susceptibility is visually exhibited through his nakedness, the fact that he is performing alone, and through his wounds. It is also reflected in the authorities' response to his actions, as their punitive repercussions confirm Pavlensky's status as an assailable individual, while simultaneously affirming the control and power of the state. At the same time, however, one may ask why the authorities consider it necessary to respond so strongly to a body in pain that at times is even completely immobilized. Does a wounded body really posit a threat to the social order? Judging by the reactions of the Russian authorities, the answer is yes, and thereby raises a certain paradox: by reacting so aggressively to Pavlensky's actions, the authorities a ctually

\footnotetext{
${ }^{53}$ A melia Jones has also challenged the notion that pain is exclusively private in nature. Focusing on the presence of the physical wound, Jones notes that our perception of someone's wound as actual makes us realize that our own body may be wounded as well. Potentially, the wound can therefore challenge the strict boundaries between myself and my other, a notion that may have politicalimplications. See Jones, "Performing the Wounded Body: Pain, A ffect, and the Radical Relationality of Meaning," Parallax 15, no. 4 (2009): 55 .

54 Bourke, The Story of Pain, 19.

55 Judith Butler, Frames of War: When Is Life Grievable? (London/Brooklyn, NY: V erso, 2009), 33 . For other accounts of vulnerability as a shared human condition with a political potential, see Debra Bergoffen, "February 22, 2001: T oward a Politics of the Vulnerable Body" in Hypatia 18, no.1 (Winter 2003); "Exploiting the Dignity of the V ulnerable Body: Rape as a Weapon of War" in Philosophical Papers 38 no.3 (2009); and A driana Cavarero's Horrorism: Naming Contemporary Violence (New York: Columbia University Press, 2008). The connection between Pavlensky's action and vulnerability was also pointed out by Colleen McQuillen in her conference paper "The V ulnerable Body as a Political Instrument in Contemporary Russian Art Activism," presented at the annual convention of the Modern Language Association, A ustin, Texas, January 7-10, 2016.

56 Judith Butler, Precarious Life: The Powers of Mourning and Violence (London/Brooklyn, NY: V erso, $2006), 31$.

57 Judith Butler, "Rethinking Vulnerability and Resistance," paper pres ented in Madrid, June 2014.
} 
acknowledge his potent bodily rhetoric and clear political potential. It is here that the power of the vulnerable body truly manifests itself and becomes a body of social dissensus and agency.

Although one may claim that Pavlensky's actions are more explicitly political than Mikhailov's Case History, both artists refuse to define vulnerability as a lack of a gency. By contextualizing the body in pain socially and historically, they show how pain is relational-in essence, both private and social-which probes us to consider our own pain and our implicit relation to the pain of others. Furthermore, Mikhailov and Pavlensky offer valuable perspectives on what it means to inhabit and depict a wounded body in public.

\section{Conclusion}

Lying face down on a beach in Greece in January 2016, the famous Chinese artistactivist Ai Weiwei reenacted the photograph of three-year-old Aylan Kurdi. The black-andwhite photograph which captured the reenactment-taken by Rohit Chawla, a photographer for one of the biggest English-news magazines in Asia, India Today-was part of a larger and exclusive photo shoot that the magazine had with Ai. Claiming that the image was a tribute to Kurdi, a press release from India Today commented on the reenactment and its public response: "The result is a world exclusive photograph that has gone viral. The whole story is one image, which is what great art is." 58

The photographic documentation and distribution of Ai's reenactment bring us back to the issues with which my paper began, concerning the fine line between journalism and sensationalism; news and entertainment; critical austerity and consumerist concerns in contemporary media, and how photographic representation of the wounded body fits into this landscape. In addition, because the photograph of Ai first appeared in a news magazine, the picture introduces another question-whether news images such as these are, or should be considered, art. In Regarding the Pain of Others, Susan Sontag reflected on viewing wartime photographs exhibited in galleries, noting that such photographs and others automatically become art once they enter the gallery space. Sontag claimed that these images merely become stations along a stroll, which may cause us to lose our ability to contemplate what we see. ${ }^{59}$ As a result, we fail to view the people in the photographs as subjects.

Jacques Rancière has keenly noted that art images do not "supply weapons for battles" but that they can inspire new configurations regarding what can be seen, said, and thought of, as long as "their meaning or effect is not anticipated." 60 This, I argue, applies to the artworks by Boris Mikhailov and Petr Pavlensky that have been the focus of my paper. By showing his Case History in some of the most prestigious galleries in the world, Mikhailov challenges the viewer to see the wounded bodies of Kharkov's homeless from an a esthetic perspective. Moreover, the participants in Mikhailov's series, who strike poses and willingly perform in front of the camera, are indirectly asking us to look at them and see them as subjects, as people in pain. In a rather different fashion, the wide media distribution of the

\footnotetext{
58 The release then went on to mention that a full interview with $\mathrm{A}$ i and more pictures from the shoot would appear in the magazine's next is sue. "A rtist Ai Weiwei poses as Aylan Kurdi for India Today magazine," India Today, February 1,2016, http://indiatoday.intoday.in/story/artist-ai-weiwei-poses-asaylan-kurdi-for-india-today-magazine/1/584804.html.

59 Sontag, Regarding the Pain of Others, 121.

${ }^{60}$ Rancière, "The Intolerable I mage," 103.
} 
photographs documenting Pavlensky's actions, and the attention they elicit, reveals that we are not sure how to approach the wounded body when it is explicitly-and voluntarilyperformed. By gaining attention from some of the major news companies in the world, websites and magazines become Pavlensky's personal exhibition space, making the viewer wonder whether she is witnessing art or international news. This speaks to the aesthetic, political, and social implications of these artists' engagement with the wounded body. Rather than viewing Mikhailov's Case History, Pavlensky's actions, and works like the m by other artists as romanticizing or sensationalizing suffering, these projects need to be contextualized within a larger (art) historical setting. Only then will we fully comprehend the significance of pain in these artworks.

While I do not suggest that the representations of pain in Mikhailov's photographs and in the images documenting Pavlensky's performance-actions are more authentic or rea/ than others, the wounded body in their art still stands forth as a body of agency and personal volition; as a body that may appeal to our voyeurism, but that simultaneously challenges us to contemplate what we are seeing and why we are watching. The wounded body may provoke and upset, surprise and appall, but it always challenges, always resists. As history takes yet another turn, one may hope that such a body will haunt us.

\section{Acknowledgements}

I would like to express my sincere gratitude to my two anonymous reviewers for their invaluable comments, criticism and suggestions. I am grateful to Molly Brunson for her helpful feedback on a seminar paper on Boris Mikhailov and for challenging me to think more about his work, and to Marijeta Bozovic for fruitful conversations on the connection between politics and bodies. For introducing me to the diverse field of performance studies and for his priceless mentorship, I thank Joseph Roach. Thanks also to Petr Pavlensky for willingly answering my questions and for granting me permission to use his personal photographs. Lastly, profound appreciation is extended to my editor, Nicole F. Scalissi: I could not have asked for a more attentive reader, whose professional insights have greatly benefitted my paper. 
$(\mathrm{cc})$ BY

New articles in this journal are licensed under a Creative Commons Attribution 4.0 United States License.

\section{ULLS D-Sorke}

This journal is operated by the $\underline{U}$ niversity Library System of the $\underline{U}$ niversity of Pittsburgh as part of its D-Scribe Digital Publishing Program, and is co-sponsored by the University of Pittsburgh Press. 

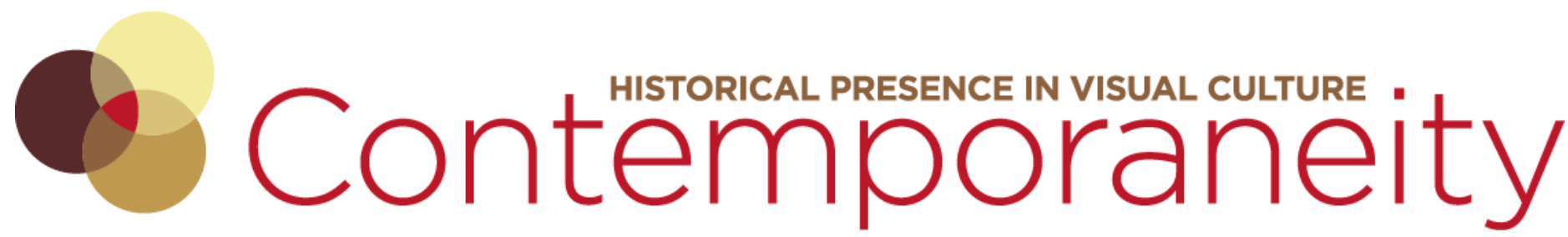

Vol 5, No 1 "Agency in Motion" (2016) | ISSN 2155-1162 (online) | DOI

\title{
Awakening Objects and Indigenizing the Museum Stephen Gilchrist in Conversation with Henry F. Skerritt
}

\begin{abstract}
Curated by Stephen Gilchrist, Everywhen: The Eternal Present in Indigenous Art from Australia was held at Harvard Art Museums from February 5, 2016-September 18, 2016. The exhibition was a survey of contemporary Indigenous art from Australia, exploring the ways in which time is embedded within Indigenous artistic, social, historical, and philosophical life. The exhibition included more than seventy works drawn from public and private collections in Australia and the United States, and featured many works that have never been seen outside Australia. Everywhen is Gilchrist's second major exhibition in the United States, following Crossing Cultures: The Owen and Wagner Collection of Contemporary Aboriginal Australian Art at the Hood Museum of Art in 2012. Conducted on April 22, 2016, this conversation considers the position of Indigenous art in the museum, and the active ways in which curators and institutions can work to "indigenize" their institutions. Gilchrist discusses the evolution of Everywhen, along with the curatorial strategies employed to change the status of object-viewer relations in the exhibition. The transcription has been edited for clarity.
\end{abstract}

\section{About the Authors}

Belonging to the Yamatji people of northwest Western Australia, Stephen Gilchrist is Associate Lecturer of Indigenous Art at the University of Sydney. He was the Australian Studies Visiting Curator at the Harvard Art Museums where he curated Everywhen: The Eternal Present in Indigenous Art from Australia.

Henry F. Skerritt is curator of Indigenous art of Australia at the Kluge-Ruhe Aborigina I Art Collection, University of Virginia. Skerritt is a doctoral candidate in the Department of History of Art and Architecture at the University of Pittsburgh. 


\section{Awakening Objects and Indigenizing the Museum} Stephen Gilchrist in Conversation with Henry F. Skerritt
Henry F. Skerritt (HS): I'd like to start by discussing your evolution as a curator, and in particular, how it shapes the thinking behind Everywhen.

Stephen Gilchrist (SG): Well, my work as a curator can be characterized by un-belonging and belonging-working within institutions and without-and the pros and cons that come with both of those opportunities. As a curator I want to keep trying new things by working with different artists, different collections, and different spaces. I've worked with Australian state and national collections and at university art museums in North America. For what it's worth, I consider myself to be a curator of contemporary art and so the Everywhen show was an opportunity for me to work more explicitly with historic objects. The invitation for this show was to thin $\mathrm{k}$ about those ideas that I bring about the contemporary, of presentness, of nowness, and to place them in conversation with the history of collections. Within this framework, I was hopeful that the show could also be an intervention into those collections.

HS: That's interesting because you've already brought up the idea of the historical. At the same time, Everywhen to me is a very conceptual exhibition. It's quite different to any surveys of its kind staged before. What were you trying to do with that show in particular, and what were the particular challenges that it brought up?

SG: For me, the provocation of the show is really to imagine the world otherwise: to think through, between, and beyond, what we've been presented as the dominant narratives of Indigenous art and culture. Colonization isn't the meta-narrative of Indigeneity, but people often think that it is, so in this show I wanted to explore other ways of being in time; the rhythms of seasonal time, the shape-shifting of ancestral time, the measures of ceremonial time in addition to colonial and post-colonial time. I wanted people to engage not just with the 228 years since colonization, but also with the 40,000 plus years of Indigenous residence on the place now termed Australia. The invitation for visitors is to become synchronous with the Everywhen, even if only momentarily, and by doing so they could lessen the burden of the colonial register in this exhibition. Of course colonization is there, it's never going away, but you can try to blunt it somehow.

And to me this methodological approach endorses the potential of Indigenization within museums. It is a process of un-assimilation. By making the frames of reference to be wholly Indigenous, as much as we can, we are not just decolonizing the space, we are in fact Indigenizing it.

HS: Can you just tease out the distinction there? It strikes me that part of that distinction is one of intersubjectivity. You're trying to get away from this dialectic that frames the colonizer and the colonized in this kind of mutually dependent power relationship, is that right? 

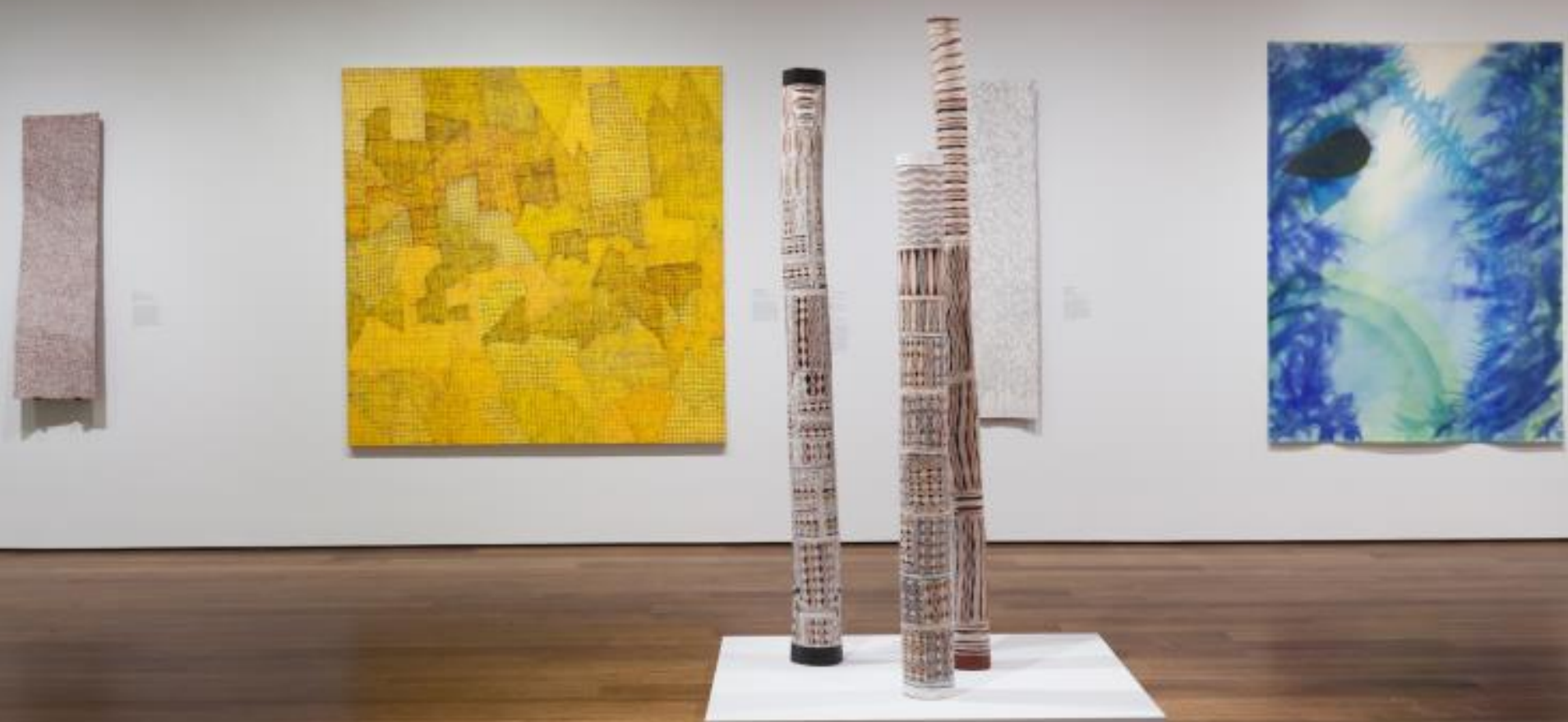

\section{Figure 1}

Installation view of "Seasonality" module from Everywhen: The Eternal Present in Indigenous Art from Australia, Harvard A rt M useums, Cambridge, MA, curated by Stephen Gilchrist. Works left to right: Gulumbu Y unupingu, Garak IV (The Universe), 2004 ; Regina Pilawuk Wils on, Syaw (Fish Net), 2008; Yumutjin Wunungmurra, Gangan to Baraltja (larrakitj), 2005; Djirrirra Wunungmurra, Dhalwangu (larrakitj), 2005; Djambawa Marawili, Dhakandjali-Dhupundji (larrakitj), 2006; Djirrirra Wunungmurra, Yukuwa, 2010 ; and Judy Watson, Bunya, 2011 . Image Courtesy Harvard Art Museums, ( President and Fellows of Harvard College. 
SG: Exactly. The exhibition isn't merely about time, it is also about power and who gets to claim time, history, place, and cultural memory. The essential question for me is not why are we excluded from cultural texts and institutions, art histories, and formations of nationhood, but why are we part of these systems to begin with. The norm is a disruption for Indigenous people, so how can we disrupt this historical violence that has become normative? For me, one possible strategy is to return to the foundational narratives of place, people and practice and to weave those into the internal logic of the exhibition.

Even though both strategies are necessary and productive, I feel that there is a different inflection between a curatorial practice that privileges philosophies of decolonization over Indigenization. For me at least, the former is about undoing something that invariably feels like you are forever playing catch up. Indigenization for me is about doing ; manifesting, instantiating, and running our own race on our own terms. I am reluctant to say the distinction is between "undoing" and "being" as I don't want to reproduce unhelpful essentialist tropes, but I think there is something crucial about openness and creating openings to Indigenous ways of seeing, knowing, and being.

HS: And how is that being received in the USA?

SG: It's so hard to be objective.

HS: Well you don't have to be objective.

SG: Well, there is actually a lot of freedom in doing a show for North American a udiences, because many of the signposts that are used and are useful for Australian audiences don't register here. Conceptually, I needed to disrespect chronology, to disrespect the se colonial geographies, and to disrespect these distinctions between the urban, the remote and the rural, but they were also practical considerations too. I want people to understand the breadth, sophistication, beauty, and politics of Indigenous art and I hope that most visitors get a sense of that. It would be great if visitors could spend time with these unfamiliar ideas that can potentially recalibrate their understanding of Indigeneity.

HS: Let's get down to more practical questions. Can we talk a bit about the show's evolution? I'm thinking here very much in the practical sense, the way you went through thinking about the collections at Harvard, and but also of the other collections that you drew from. What do the practicalities of putting a show like this together look like?

SG: My very first visit to Harvard University included a tour of the collection storage at the Peabody Museum of Archaeology and Ethnology, but at that stage I didn't really have a clear idea of what I wanted to see, as I didn't really know what was there. With the Collections Manager, I was pulling out drawers, looking, seeing, listening to which objects spoke to me and which objects were of interest. One of the first groups of objects that I saw were the beautiful riji (engraved pearl shells) that we have in the exhibition. One in particular was a broken pearl shell, with incised geometric designs that were infilled and rubbed with ochre. What interested me was that it represented a fragment of material culture that was thousands and thousands of miles from where it came from. But it also voiced this promissory moment of reconnection. I wanted the objects to go through this process of somehow returning to the communities from which they came. 
Museums do represent loss for Indigenous peoples, so this object literalized these ideas of brokenness and of being incomplete. I wanted the objects to represent both the ceremonies that never were, the ceremonies that never could be, but also be a conduit of reconnection. Sometimes, the information that we have as museum professionals and as Indigenous people is not just incomplete, but incompletable. But this process of falling into the unknown brings us closer to who we were, who we are, and who we will be.

An important component of this idea of reconnection was touch. And so I chose objects from the Peabody's collection that were and are cradled, woven, worn, held close, performed, struck. In this exhibition we have coolamons (vessels), basketry, mats, pearl shells, drums, and three larrakitj (hollow log coffins) to demonstrate a life lived through objects and how the abstracted Indigenous body becomes reconstituted.

Interestingly, we received instructions from a community about who exactly could touch their objects. And it was a great reminder that touch is conditional, relational and it is also a gift. The objects are like the notation but when they come into contact with communities in real and symbolic ways, this notation becomes music.

HS: I think that's a segue to talk about objects, because one of the things that strikes me about this show, Everywhen, and Crossing Cultures and some of the other shows that you've done, is that you seem very interested in allowing the objects to speak and allowing them to speak in relation to other objects. ${ }^{1}$ Often there seems to be a feeling with Aboriginal art exhibitions that, in order to provide adequate "context," the exhibitions must include mountains of text, video, audio, and other supplementary material. How do you deal with objects whose meanings are often ambiguous or alien to viewers, particularly in America, and how can objects in museums speak without the curator speaking for them?

SG: I think that is one of the most difficult tasks as a curator. I actually think that we do have a lot of text, almost every object has its own extended label of about 150 words, we do have video interviews with artists in the space and we do have regular guided tours. As a teaching museum, the exhibition had to fulfill certain pedagogical takeaways and I had to give people enough points of access, in multiple platforms for them to respond to the visual, auditory, temporal, and scholarly information in the space. These are fairly traditional ways of communicating information but they don't by themselves do the work that needs to be done by the visitor or even the object.

HS: Can you expand on what you mean by that? Because I think there is something about your curating that is very respectful to honoring the works and their creators, and their cultures. So what do you mean when you say that it is a really traditional manner? Because, I think that term has slightly different connotations in the American and Australian contexts.

1 See Stephen Gilchrist, ed., Crossing Cultures: The Owen and Wagner Collection of Contemporary Aboriginal Aus tralian Art at the Hood Museum of Art (Hanover, N H: Hood Museum of Art, Dartmouth College, 2012). 
SG: Yes, we are talking about two overlapping sets of traditions. As a curator or art historian you can't be closed to what the object is trying to say to you or to a udiences. Indigenous people sometimes describe it as "waking up objects," so the first point of departure is being open to these awakenings with objects. And that means having a reverence and a respect for these objects, recognizing that you can unlock this cultural information through these encounters, sometimes through touch, but, also through the other senses as well: looking, smelling, listening, touching. I think that is a traditional Indigenous way.

I think art museums produce particular ways of thinking and behaving. You read a label that has an authoritative, omniscient voice that is based on the assumption that we're all children of the Enlightenment, and that we want to have these rational, scientific labels. I'm not suggesting that there is no reason or intellectualism in Indigenous culture, but I am much more interested in different philosophies of perception. There are ways of understanding these objects that aren't necessarily cognitive.

HS: I think this comes back to the idea you'd spoke of earlier about Indigenizing the museum. You've written about shifting the role of the ethnographic museum to allow for the reaffirmation and reinterpretation of objects for Indigenous peoples. How do you think museums can take an alternative role for Indigenous peoples, to allow them to get in touch with their pasts and identities? Is that possible in a show like Everywhen that is so far from the geographic point of origin of the works? And does it require museums to completely rethink that kind of Enlightenment way of doing things as well, and to open themselves up to alternative ways of experiencing objects?

SG: Two of the works in the show are cylindrical-shaped ochred baskets that had become flattened and misaligned over the years. I chose them because they had these great abrasions from the wearer's shoulders showing the body imprinted on the object. Louise Hamby who had a Visiting Fellowship at the Peabody Museum invited an important Elder from Milingimbi to look at these works. When we selected them for display, Peabody conservators reversed the damage and by putting them on display, the works were awakened. It was through these active and generative encounters with those objects on a cultural but also a material level. Even though they are far from home, these objects become renewed through these active encounters.

HS: One of the things that strikes me is your emphasis on praxis, and on the active process of Indigenizing over the essentialized idea of Indigenous curating. I know you've spoken about striking a balance between Indigeneity as a strategically essentialist mode and a form of active being in the world. I'd like to try and tease out what this looks like in practice in the context of curating. What are the things that institutions might do to move forward in Indigenizing their institutions?

SG: Well, I think it's about recalibrating their relationship to the objects away from preservation into activation. It is about activating relationships and not defining them. Objects become fully realized through active encounters with their community. The cultural memory of objects resides with the community, and institutions need to be mindful of this. From the beginning, the objects for me weren't objects at all. They were subjects, and the challenge was how to deploy this subjective status for the viewer and for the institution.

At the opening of the show, I spoke about openness and being open. Institutions have to be open, and not closed to entering into dialogues about the memory of these cultural objects 
and the custodianship of these objects. I think that is the first step. It's not necessarily about having Indigenous curators or, curators who have an Indigenist approach. The museum itself has to be open to this process of Indigenization.

HS: When you talk about that it sounds like a lot of it operates outside of the exhibition itself. Where do exhibitions fit into this? I think of how someone like Jens Hoffmann has started to refer to himself as an "exhibition maker" as opposed to a curator, in order to draw a distinction between these two practices. But it seems to me, when you talk about curating, you are speaking about it as a much broader activity.

SG: Like painting is more than painting, curating is more than curating. It is a social practice and a form of activism, and those modalities are engaged within the space, but also, as you say, outside the exhibition space.

For me, an exhibition is about "presencing." It is about being in and with the presence of the ancestors, but it is also about bringing things into view, into focus, into relief. Sometimes it is less about the accomplishment of that goal and more about the effort.

I'm particularly thinking about the objects whose original names have been erased. We engage with the object and with the community to allow for a surfacing of information that can be presented in the space. We changed the labels to read "Unidentified Artist" rather than "Unknown Maker," and for me this was about presencing the humanness of the makers and perhaps the carelessness of the collectors. Within these histories of erasure what can still be presenced?

HS: How have the various projects that you've worked on before helped you to develop your ideas on the possibilities and the potentials of an Indigenized practice, and how do you see the state of the field both locally and globally?

SG: Yeah, that is a hard question to answer for all kinds of reasons.

HS: Well, maybe a different way to approach the question is to ask who you would see as mentors, and what you learned from them. But also, how do you think that the challenges are different for an Indigenous curator working today as opposed to your predecessors, such as Hetti Perkins, Brenda Croft, or Djon Mundine?

SG: Yes, they are definitely my curatorial mentors and tormentors and I have learnt so much from them. One lesson is to use the enviable platform that we are given as curators to speak truth to power. But the monopolies of violence over our Indigenous communities a re even greater today, and the risks of speaking out are high.

I worry about the state of Indigenous art at the moment. We reached a point, I guess in 2008, where there were Indigenous curators in every single state art gallery in Australia and of course the National Gallery of Australia. Since then, though, we have had a numerical regression with a number of high-profile senior level curators standing down, I think as a vote of no confidence in these institutions. But we have also had these locational regressions, where the space afforded to Indigenous art is shrinking. I guess it comes as no surprise when, as a nation, we have basically been going backwards politically. So I find all this very troubling. However, there is also a growing interest in Indigenous art internationally and I definitely see that continuing. 
HS: I know it's a difficult question, but why do you think that this regression has happened?

SG: I do think, on one level Indigenous art has been a victim of its own success in Australia . Indigenous art was everywhere for a while. And, maybe audiences in Australia did reach a kind of saturation point and were no longer receptive to what it offered. For me it has been really great working in an international sphere, where Aboriginal art is not the Other to Australian art. It is immediately and necessarily part of an internationalized discussion around the categories of contemporary art and, by virtue of being seen in these new contexts, it creates expansionary movement in our understanding, awareness, and cultural value.

HS: I think that's an interesting question, about the sort of difference between the local to global context. I pulled this quote of yours that I liked a lot, where you said, "The lesson of Indigenous art is not that it behaves differently from contemporary art, but rather that contemporary art can no longer be considered a singular entity. Like the other myriad alternate forms of contemporary art practice current today, Indigenous art must be evaluated on its own terms." I I like that quote because it gets to the heart of a lot of the complex challenges that Aboriginal art poses in the contemporary art world context.

SG: I think maybe that the first wave of Indigenous curators were necessarily about visibility. It was about localized resistance to institutions that were refusing to exhibit Indigenous art and even refusing to consider Indigenous art as fine art, let alone contemporary art. I think new generations of Indigenous artists and curators are grappling with not necessarily the politics of exclusion, but the politics of inclusion, as in, how do we position ourselves? Now that we're here, we don't have to defend who we are, we get to define who we are. We don't have to be understood in opposition to the dominant culture, but we can be understood in relation to and with ourselves.

HS: In your essay "Indigenising Curatorial Practice" you make the point, that attempts to position Indigenous art globally often end up implying that Indigenous art needs the validation of the Western art world. ${ }^{3}$ But it strikes me that you're seeing an opportunity in this globalized space to enliven the world. You conclude your catalogue essay by saying, "[t]he Everywhen can show us that Indigenous art and culture do not merely represent the time before time, but in fact, awaken us to the fullness of it." ${ }^{4}$ I wonder if you can speak then to this question of separatism because it seems to me that separatism as a concept makes a lot more sense in Australia than it does for a curator in the USA. I guess the question is, where your international experience forces you to take different stances in the Australian context than the American context on these ideas.

\footnotetext{
2 Stephen Gilchrist and Jananggoo Butcher Cherel, "Am I a Good Painter or Not?" in No Boundaries, ed. Henry F. Skerritt (Reno and New York: Nevada Museum of Art and Prestel, 2014), 48.

3 Stephen Gilchrist, "Indigenising Curatorial Practice," in The World is not a Foreign Land, ed. Quentin Sprague (Parville: Ian Potter Museum of Art, University of Melbourne, 2014), 55-59.

4 Stephen Gilchrist, ed. Everywhen: The Eternal Present in Indigenous Art from Australia (Cambridge, MA: Harvard Art Museums, 2016), 30.
} 
SG: Absolutely. It's not that the stakes are higher or lower, but the stakes are definitely different. Every exhibition is a curatorial exercise in wayfinding, and I think this exhibition has taught me that as I move through the world, relationships are my politics. It is about intellectual, cultural, and political engagement, and who we can bring with us into this collective and often difficult "we."

I felt that I was also using the institutional armature of Harvard University to state something that to me is self-evident. Aboriginal art isn't of the margins. It is something that is self-possessed and deserving of its own value. The work of the viewer is to not just question the canon, but question canonicity itself. The job of the curator is to negotiate the Indigenous systems of value that don't change with those that do.

HS: So, in that sense then, do you see yourself having to take on the role of translator, trying to translate one world into another world?

SG: Translation is definitely part of it but I think it's also about unsettling one world so it can better recognize the other.

HS: Critics like Tony Bennett have made a strong case that the institution of the museum is designed to perpetuate a very modernist and progressive version of time. ${ }^{5}$ Everywhen seems very much an attempt to work against the hegemony of progressive time. Returning to the question of Indigenizing the museum, how do you think that Indigenous cultural practices can work within or against the in-built temporal frames of the museum?

SG: When I was initially thinking about this exhibition and even when we were installing it, I did envision the museum as this site of temporal collapse. But it isn't about the disintegration or the flattening of time. It is about the possibilities of activating these registers of the past, present, and future.

The white-rectilinear galleries that I was given to work with have their own histories and significations and the only way I could address it was through configuring the exhibition as this endless figure eight which obviously is about non-linearity. The themes of the show are, like time itself, overlapping, dynamic and interactive and as you move through the space, you move through, between, and beyond these Indigenous temporal frames.

HS: I guess that that is the essence of not fetishizing the museum. I sometimes feel that there is a danger in hardline Foucauldian arguments of reifying the power structures, and then perpetuating their power. But if you don't let those power structures dictate, then there is the possibility of working within them as well against them. 

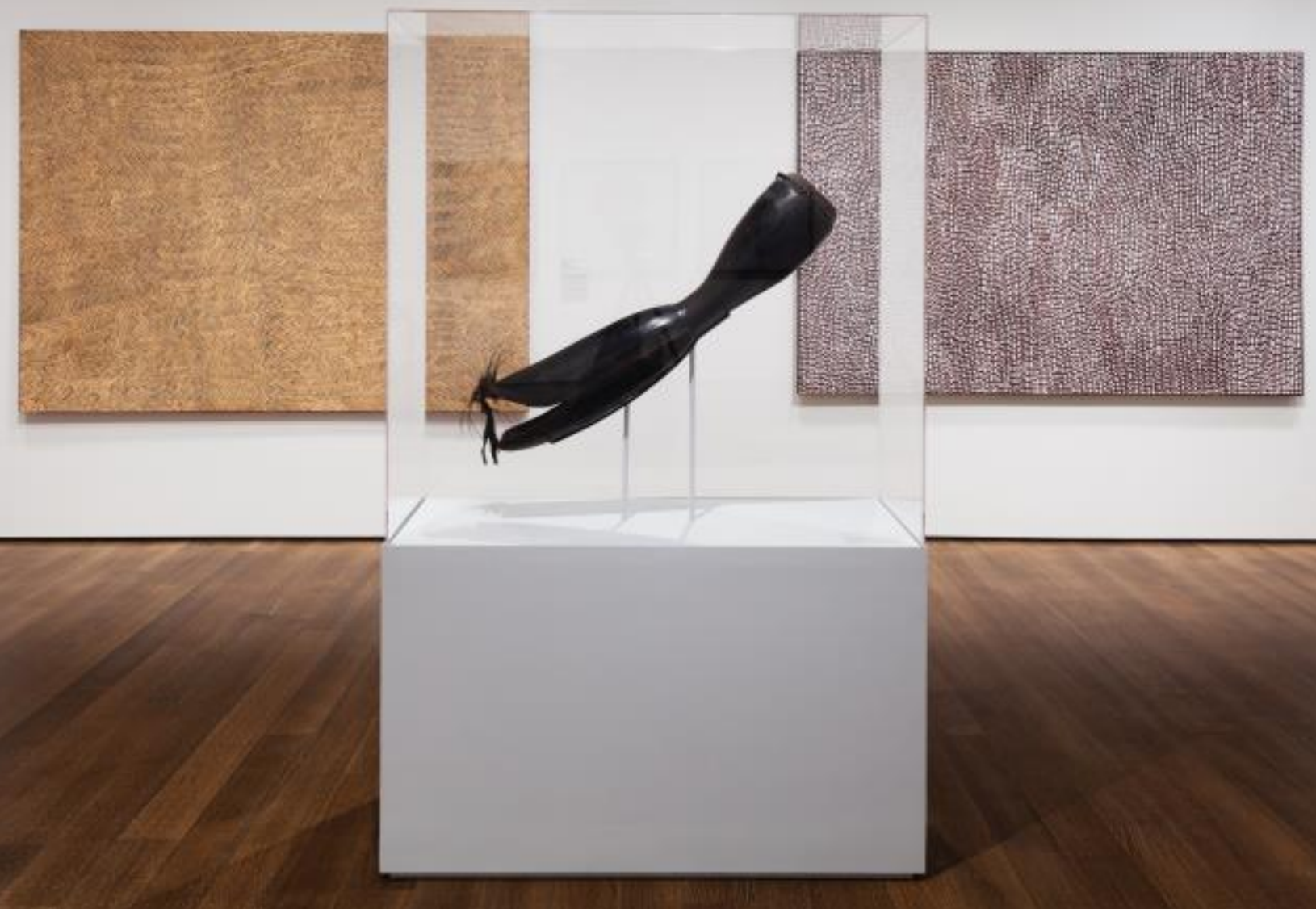

Figure 4

Installation view of "Performance" module from Everywhen: The Eternal Present in Indigenous Art from Aus tralia, Harvard A rt Museums, Cambridge, MA, curated by Stephen Gilchrist. Works left to right: Doreen Reid Nakamarra, Untitled, 2007; U nidentified artist, Warup (Drum), mid-19th-early 20th century; and Dorothy Napangardi, Karntakurlangu Jukurrpa, 2002. I mage Courtesy Harvard A rt Museums, ( ) P resident and Fellows of Harvard College. 
SG: Yes, I mean for me it's about redirecting energy and modeling these values within a space of discomfort but also a space of reciprocity. Your question was about museum framing and seeing?

HS: Yeah, that's right, I mean you are still working within a muse um context. But it seems to me that Everywhen is very successful at working against those frames without necessarily being explicit in the way that it's doing it. It feels like quite a subtle piece of subterfuge.

SG: There's always a little bit of stealth work that is required and I do think it is probably closer to subversion than inversion. But at the same time, I was very up front about what I was doing and why I was doing it and asking why it hadn't been done before.

The Harvard Art Museums didn't want me to be curatorially anonymous and so they encouraged me to use my voice and the voicings of the artists to achieve these aims. With some things like the surfacing of Indigenous words for Indigenous objects, I didn't ask permission, but I also didn't think that I needed to.

HS: How would you respond to Indigenous American artists or curators who might argue that they face the same problems here, that Indigenous Australian curators face in Australia. I guess this a dual question, how do you think what you're doing here might be able to have an impact in Australia? But also, how do you think it might be able to impact what's going on in the local context here with Indigenous practice, which has really, I think, been neglected in a very big way?

SG: Oh, yeah, absolutely. At all the talks and lectures and presentations, and film screenings that we have had at Harvard, we have begun with an acknowledgement of country. And it's been really amazing how this small, but important gesture can really change the way people understand the place we are in. Some people have found it quite profound, and I've been struck by how necessary those things are because of the neglect of the incredible art practices of Native American artists. People have said to me, "you know, this [Everywhen] is great, but it'd be great to also see a Native American show here." And I have to say, I completely agree. What we have to do is just to try and show support, and show that we're trying to unpack some of the same things. So it's a case of trying to do two things at one time. I'm asking people to think about what happened in Australia, but also what happened here as well, so hopefully there's two takeaways to the show. 
$(\mathrm{cc})$ BY

New articles in this journal are licensed under a Creative Commons Attribution 4.0 United States License.

\section{UILIS D-Surle}

This journal is operated by the $U$ niversity Library System of the $U$ niversity of Pittsburgh as part of its D-Scribe Digital Publishing Program, and is co-sponsored by the University of Pittsburgh Press. 

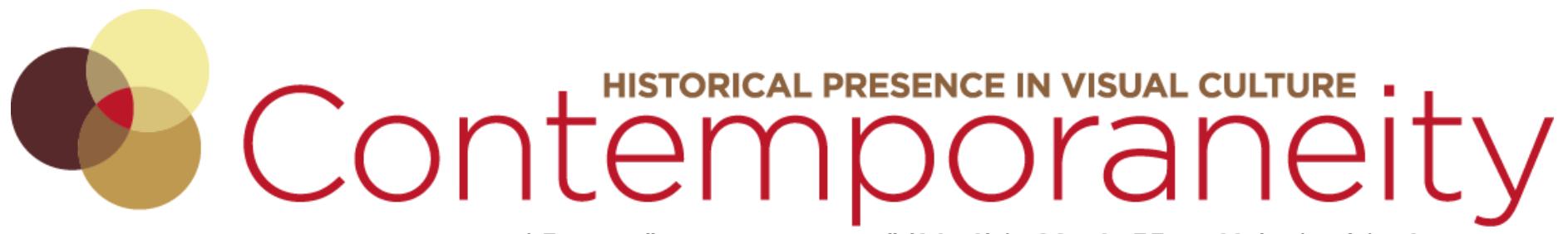

Vol 5, No 1 "Agency in Motion" (2016) | ISSN 2155-1162 (online) | DOI

\title{
Curator-Curatorial Studies
}

Towards Co-creation and Multiple Agencies

\author{
Erin A. Peters
}

\section{Abstract}

Erin A. Peters reflects on her objectives as a curator and educator, and the agency of museum visitors as co-creators.

\section{About the Author}

Erin Peters is Joint Lecturer in Curatorial Studies at the University of Pittsburgh and Assistant Curator in Science and Research at the Carnegie Museum of Natural History. Peters holds a MA in Egyptology, a MA in Museum Professions, and a PhD in art history, for which her dissertation, "Egypt in Empire: Augustan Temple Art and Architecture at Karnak, Philae, Kalabsha, Dendur, and Alexandria," won the 2015 University of Iowa D. C. Spriesters bach Dissertation Prize in the Humanities and the Fine Arts. While completing dissertation research, Peters was a Metropolitan Museum of Art Chester Dale Fellow in the Department of Egyptian Art where she was the primary researcher for the Digital Department's MediaLab and Egyptian Art collaboration, "Color the Temple." The collaboration (re)colored the Augustan temple of Dendur using projection mapping technology to engage museum visitors by showing the temple in a way it had yet to be seen at the Met-in (virtual) color. The Met's project is an example of the kind of collaborative work that Peters hopes to build on in working towards a robust museum profession for the future. 


\section{Curator-Curatorial Studies}

\section{Towards Co-creation and Multiple Agencies}

When asked to contribute an essay about the agency of curatorial practice I thought the timing was ideal for a reflective exercise to inform my own practice and teaching. I recently completed the first academic year of my post as Joint Lecturer in Curatorial Studies in History of Art and Architecture's (HAA) Museum Studies program at the University of Pittsburgh and Assistant Curator in Science and Research at the Carnegie Muse um of Natural History (CMNH). My position was created as part of a larger project to build a robust collaboration between HAA and Pittsburgh's rich cultural institutions funded by an Andrew W. Mellon Foundation grant awarded to HAA. My charge within this larger project is to continue to develop my practice as a museum curator in the Carnegie Museums of Pitts burgh (CMP) so that I can be best prepared to teach museum studies students about curatorial practice and the museum field overall. ${ }^{1}$ The particulars of my placement in CMP, my explorations of the current state of the museum field in preparation for teaching, the run of my spring 2016 course "Introduction to Museum Studies in the Carnegie Museums of Pittsburgh," and reading the transcript of the 2014 panel "Curatorial Practice as Production of Visual and Spatial Knowledge," published in Contemporaneity edition 4, put me at a perfect prospect to reflect and forecast hopes for my own curatorial practice and teaching curatorial studies. ${ }^{2}$

Beginning with the panel discussion will be a productive start to the exercise. The panel brought together curators of art, science, and digital data for a conversation about how curating creates visual and spatial knowledge in general and in specific disciplines. ${ }^{3}$ The conversation showed general themes, in which curator of contemporary art Dan Byers and theorist of curatorial practice Terry Smith both emphasized the importance of exhibition making in curatorial practice. ${ }^{4}$ Curator of the Hall of Botany, Cynthia Morton, described her role as a scientific researcher nominally separated from the exhibit process, instead making her information available in academic/scientific publications. ${ }^{5}$ Thinking thro ugh the idea of "digital curation," Alison Langmead talked about how making digital data (images) available is "exhibiting" within a digital space. ${ }^{6} \mathrm{I}^{\prime} l l$ add my own perspective to the mix here. My academic training in Egyptology, art history, museum studies, and museum practice as a fellow in the Department of Egyptian Art at the Metropolitan Museum of Art prepared me to be a curator of material culture from Egypt as a specialist in which exhibit-making is one part of the job, on equal footing with carrying out an active research agenda as a steward of

\footnotetext{
${ }^{1}$ The Carnegie Museums of Pittsburgh is comprised of four dis tinct mus eums: Carnegie Museum of A rt, Carnegie M useum of Natural History, Carnegie Science Center, and The A ndy Warhol Museum.

${ }^{2} \mathrm{Nicole}$ Scalissi, et al., "C uratorial Practice as Production of V isual and Spatial Knowledge: Panel Discussion, O ctober 4, 2014," Contemporaneity: Historical Presence in Vis ual Culture 4, no. 1 (2015): 144-163. The panel was part of Debating Visual Knowledge, a symposium organized by graduate students in Information Science and History of A rt and A rchitecture departments at the U niversity of Pittsburgh, O ctober 3-5, 2014.

${ }^{3}$ Scalissi et al., 144.

${ }^{4}$ Ibid., 145 and 147.

${ }^{5}$ Ibid., 145 .

${ }^{6}$ Ibid., 149 .
} 
collections. In my experience, a curator of ancient art (or other historic art) is significantly different from a curator of contemporary art, and seems to blend practices of art and science curators. In looking for commonalities across curators of contemporary art, science, digital data, and ancient material culture from the information here, perhaps it can be said a curator generally uses research, knowledge, and opinion to select and collect, and combine elements (objects and ideas) into a different thing than the thing was alone before being collected and combined (in a museum collection, an exhibition, a research publication). In this vein, and in simpler terms, a curator selects a thing as important through research and expertise, cares for and preserves it, interprets it, and makes it available and viewable.

Two things immediately strike me as missing in such a curatorial practice: the agency of people (audiences) and of objects/things. If looking to reception theory, and agency of material culture, a more nuanced and holistic picture can come into view. ${ }^{7}$ When looking for the agency of people in the 2014 panel publication, there were few positive allusions, and panelists were more generally disparaging towards audience participation. For instance, in his published reflection on the panel, Dan Byers commented that

The public remains the most vital voice within any museum, and differentiates it from the academy. Knowledge and experience is shared, and in the sharing, culture is made. But as the emphasis is placed on spectacle, and on audience 'development,' 'engagement,' and 'participation,' (all concepts which are very easily bastardized today towards lowest common denominator ends), art museums could benefit from curators who have also spent long years in conversation with artists and researching in private. ${ }^{8}$

But if we go beyond seeing audience participation in museums as solely something to seek, entice, and therefore control, and also take participation as a given through reception, more productive practices of curator-audience co-creation could be developed. In reception/viewer theory, meaning is made through individual reception and perception, as well as social interaction. ${ }^{9}$ This meaning-making happens parallel to or apart from constructed meaning imposed through curatorial messages. If we were to appreciate audience self-made meaning as equally valuable as our specialist meaning, and to solicit it in

\footnotetext{
${ }^{7}$ For instance, Wolfgang Kemp adds to reception theories and describes the "beholder" with "preconditions" like specific gender, presence, and history, which intrinsically inform an experience with a work of art (which has its own set of preconditions). In Kemp's methodology of reception aesthetics, beholders actively converse/participate with a work of art (or an exhibition, etc.), and bring innate meaning that comes from the particularities of a beholder's and an artwork's contexts. Wolfgang Kemp, "The Work of A rt and its Beholder: The Methodology of the A esthetics of Reception," in The Subjects of Art History: Historical Subjects in Contemporary Practice, ed. M.A. Cheetham et. al. (Cambridge: Cambridge University Press, 1998), 180-96. A Ifred Gell, Art and Agency: An Anthropological Theory (Oxford: Clarendon Press, 1998) remains the primary source for the agency of material culture.

8 A lison Langmead, Dan Byers, Cynthia Morton, "C uratorial Practice as Production of Visual and Spatial Knowledge: Panelists Respond," Contemporaneity: Historical Presence in Visual Culture 4, no. 1 (2015): 161.

${ }^{9}$ E.g. Christian Heath and Dirk V om Lehn, "C onfiguring Reception (Dis-) Regarding the 'Spectator' in Museums and Galleries," Theory, Culture \& Society 21, no. 6 (2004): 43-65; Fred Myers, "Social Agency and the Cultural Value(s) of the A rt O bject," Journal of Material Culture 9, no. 2 (2004): 203-11; Rolf Steier, Palmyre Pierroux, and Ingeborg Krange, "E mbodied Interpretation: Gesture, So cial Interaction, and Meaning Making in a National A rt Museum," Learning, Culture and Social Interaction 7 (2015): 28-42.
} 
an active process of co-creation, audience participation could be more nuanced than "spectacle." 10

I could not detect the agency of objects/things in the 2014 panel discussion, which is likely a reflection of the curatorial tendency to privilege the "original" context (or life) of an object or idea. Indeed, we generally go to great pains to "reenact" the context of the original moment of creation through research and interpretation; this is especially the case for myself and other curators of ancient material culture. This is true across different types of institutions, from anthropology, archaeology and natural history, to art museums. Even with different intentions of interpretation and display-i.e. between a didactic presentation that values knowledge and an aesthetic presentation that values the aura of an objectinformation about the original context (as we understand it) is usually conveyed through reconstruction, recreation, or label data. This kind of reenactment disregards a n object's presence and agency through time, and particularly its contemporary context as a muse um object. Going forward, if we recognize our understanding of the original context of an object or idea as one story, and present an object as a museum object by using materiality as a museological theory, we can be transparent and egalitarian in our presentation of objects and ideas. ${ }^{11}$ Through transparency and exposure of an object's lives (a multiplicity of interpretations), we can participate in critical curating, ${ }^{12}$ and also move beyond institutional critique to become a post-critical and reflexive museum profession by uniting theory and practice. ${ }^{13}$

In striving to unite theory and practice, and looking back at different understandings of curators and curatorial practice discussed here, I find it important to ask: what does this mean for me as a curator, and for the kind of curating I teach students so they can be best prepared for what curating will look like in the future? Towards this question, I will cast the net wider to think how curators function within their larger institutions, communities, and the larger museum field. For this task, museum studies - a fast developing field of study that looks at the whole of the museum profession, from daily tasks to the overarching theoretica I principles of museum practice and operation in and relation to society - can be useful. Trends in museum studies can help neutralize and contextualize a curator's practice to be holistic rather than isolationist. For instance, the trend towards the democratization of museum professions and tasks places curators as one force in a larger interconnected picture, in which exhibitions are one task. But does democratization mean doing away with specialty and rigor? I would say no; in my practice, rigorous scholarly training and practice is the core of what I can contribute. Indeed, I see specialist scholarship and research as necessary to the core of museum work so that we can be accountable for the information and experiences that we present. At the same time, I realize my perspective is only one in a web of interwoven and interdependent ones, which, in addition to a vast array of colleagues and publics, also involves objects' and audiences' agency.

\footnotetext{
${ }^{10}$ A s in Janna Graham and Shadya Yasin, "Reframing Participation in the Museum: A Syncopated Discussion," In Museums After Modernism, edited by G. Pollock and J. Zemans (Blackwell Publishing Ltd, 2008), 157-72; C atherine Evans, "The I mpact of the Participatory, V isitor-Centered M odel on C uratorial Practice," Journal of Museum Education 39, no. 2 (2014): 152-61. 
Through the process of reflection for this essay, I've identified a number of elements that I will strive to make a part of my own work as Assistant Curator and Lecturer of Curatorial Studies. I will base my practice in rigorous scholarly research with a research program in which I can participate actively in the fields relevant to ancient material culture in order to be a capable steward for the collections at the CMP. I will relate my research to the collections and also with the larger societal picture of our contemporary world, so that my work is in dialogue with a broad range of people and circumstances. I will be an advocate for the mission-driven model, while supporting missions to be nimble, in dialogue with the past, participating in the present, and with an eye to the future, in order to avoid the entrenched mantra: "we do things this way/don't do things that way." I will be transparent, and use difficult information and stories as productive points of dialogue, which may encourage us to take on blame and actively combat the colonial notion that we are here to make people better with art/knowledge by bringing them into contact with objects/ideas that we think are important. I will avoid educating people and interpreting objects, but instead acknowledge and encourage the agency of people and objects as part of curatorial work. Rather than seeing myself as a collector/caretaker for objects, space, and ideas, and then creating visual, sensory, scientific knowledge, I will aim to be a facilitator in complexity and practice curation that is ever evolving, seeks many stories, and appreciates a wide range of value systems and expertise. I hope to do this by combining my curator (specialist) authority with object and people/audience agency, both solicited and unsolicited; seeking out the least familiar and the "lowest common denominator" to shock my learned practice from comfortable process, which will ideally generate new methods of approach; and striving for true diversity that is bey ond cultural, racial, or ethnic, forcing interaction with ideas I believe to be wrong in order to promote genuine freedom of thought. This kind of curatorial practice may help me prepare the next generation of curators and museum professionals for whatever the future may bring.

\section{Erin Peters in Discussion with Annika Johnson, Co-Editor-in-Chief}

Erin Peters's vantage point at the intersection of multiple disciplines and institutions provides a unique opportunity to consider the ever-changing role of curator. When and how does curatorial agency come into play amidst the thicket of institutional visions, initiatives and everyday operations? How might curators soften disciplinary and institutional borders? Peters' personal mission statement that emerges centers on approach and action, and curatorial agency is here distributed among objects and their lives, and audience participants, who emerge as key co-creators in the mix. To follow up, I asked her a few questions about her experiences enacting this curatorial thinking (Annika Johnson).

AJ: How does the physical space of the museum factor in as an agent amidst (and literally housing) the tangle of viewer, curatorial, and object agencies? I'm curious specifically about your research on space in ancient Egypt and how this has influenced your thinking about museum space and audience agency.

EP: Excellent question-generally, I see the physical space (specifically the built environment) of the museum as part of object/thing agency, as it is in the realm of the physical/material. Just as objects housed within museums are actively charged with a myriad of stories, perspectives, and ways of communicating, so too is the space around them. Through this active agency, museum space controls and communicates. Your question about physical space makes me think about non-physical space and its agency. Of course there is virtual space, but also social space, mental space, ritual space, etc. I am intere sted in how 
these spaces intersect with the physical space of the museum, and ways curatorial practice can engage with them.

AJ: You mention that we need to move beyond institutional critique, which struck me because self-reflexivity is now pretty standard within museum practice. Within the method of curatorial practice you envision, and in your experience working with ancient art, where is institutional critique productive and where does it fall short?

EP: You are right, institutional critique/self-reflexivity is a standard in much of today's museum work and curatorial practice. I see it as continually necessary because we are far from shedding our colonial $18^{\text {th }} / 19^{\text {th }}$ century roots where museums and "art" are society conditioners, but we seem to be stuck in critique. I would say institutional critique falls short in the forever deconstructing of the museum/the market/the art world. I do think it is important to continue to expose the conditionality of art/knowledge in its economic, political, religious contexts and realities, but I don't see that critiquing the systems are enough to overcome ingrained structures or renew institutions. Rather, to move forw ard, we need to start constructing, which is where I see post-critical museum and curatorial practice as beneficial, as it calls for the development of metadisciplinary views and collaboration. The curatorial practice I hope for (and for our larger world-view) will continue to deconstruct, but also construct, ideally in some way not tied to our modern (Enlightenment) Western mindset.

AJ: After reading your Innovation Studio post "Students + Staff: Moving From Experiment to Practice," it seems that your students responded positively to the idea of a curator as an agent rather that the agent in interpreting objects. ${ }^{14}$ As students of a totally digital generation, did this seem natural to them, or was their some resistance to this idea? What excited them most about the future of museums?

EP: Indeed, my students not only responded positively to the idea of a curator as an agent, it seemed completely familiar to them, and being the agent seemed foreign. As you note, it is likely that this comes much from their presence in a digital generation, which has democratized and pluralized access and authority through the internet. It seemed what excited them most about the future of museums is where museums can be active and positive participants in societies-as connectors of objects, people, time, and space. In many ways, my students struck me as leagues ahead in thinking about museum work and curatorial practice, and I'm excited to see them as not only future museum professionals, but integral in current and present museum work, by taking experience and moving to exploration, they can help us bring about necessary evolution.

${ }^{14}$ Erin Peters, "Students + Staff: Moving from Experiment to Practice," Innovation Studio (blog), June 30, 2016 , http://studio.carnegiemuseums.org/students-staff- $4 /$. 
$(\mathrm{cc}) \mathrm{EY}$

New articles in this journal are licensed under a Creative Commons Attribution 4.0 United States License.

\section{ULLS D-Sonle}

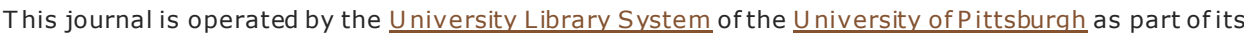

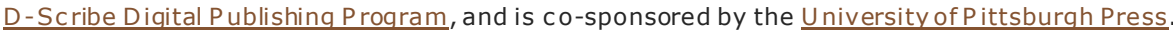



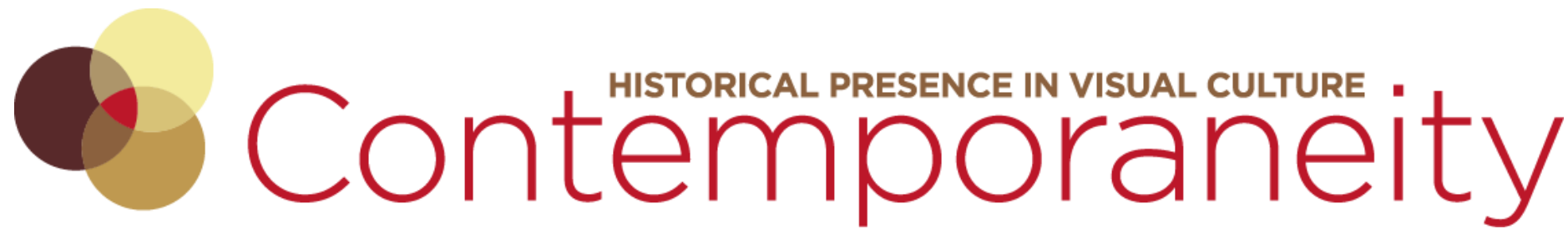

Vol 5, No 1 "Agency in Motion" (2016) | ISSN 2155-1162 (online) | DOI

\section{SuperQueeroes - Our LGBTI* Comic Book Heroes and Heroines Schwules Museum*, January 22-June 26, 2016}

Carlos Kong

\section{Exhibition Review}

SuperQueeroes - Our LGBTI* Comic Book Heroes and Heroines at the Schwules Museum*, Berlin, January 22-June 26, 2016.

\section{About the Author}

Carlos Kong is a postgraduate student at The Courtauld Institute of Art, London. He researches questions of sexuality, historical memory, and intercultural encounter across contemporary art, literature, and media. He received his BA from Cornell University, and was previously the Baden-Württemberg Foundation Fellow at Universität Heidelberg, Germany. 


\section{SuperQueeroes - Our LGBTI* Comic Book Heroes and Heroines}

\author{
Schwules Museum*, \\ January 22-June 26, 2016
}

Carlos Kong

SuperQueeroes - Our LGBTI* Comic Book Heroes and Heroines at the Schwules Museum* in Berlin (January 22, 2016-June 26, 2016) presents the first major exhibition of queer comics in Europe. ${ }^{1}$ Comprised of works by nearly one hundred comics artists and organized by seven curators, SuperQueeroes provides a comprehensive survey of comics with LGBTI characters and narratives, primarily from Europe and the United States. ${ }^{2}$ The exhibition illustrates the inventiveness and plurality of nonnormative sexual cultures to which comics graphically testify (fig. 1). As a foundational endeavor, SuperQueeroes raises a two-fold fundamental challenge-narrating sexual diversity through the disparate histories of its literary and visual representation; and curating comics in attune ment to their historical and material specificity. A critical examination of SuperQueeroes's moments of insight and inconsistency is relevant for the future scholarly and artistic work on queer comics that the exhibition will likely inspire.

Once relegated to the realms of the low and the vernacular within the mass cultural industry, comics have recently and continue to emerge within academic, curatorial, and archival contexts, redefining the scope and methodologies of cultural inquiry. Through their serial interrelation of images and texts, the manual and the mechanically reproduced, and the autobiographical and the fantastical, comics remain an elusive medium in spite of their quotidian ubiquity. While comics share affinities of genre with pop art, DIY practices, illuminated manuscripts, serial literature, and filmstrips, they remain graphically unique in literary and visual stylization.

In both their industrial norms and depicted content, comics have conventionally reflected and imagined hegemonically heteronormative worlds, particularly through the figure of "the superhero" and its implicit heroization of heterosexuality, male dominance, physical strength, and idealized bodies (Superman remains a prime example). However, recent comics and their scholarly reception have attenuated this dominant convention, in turn producing and describing the relation between comics and minoritarian historical representation. As literary and comics scholar Hillary Chute contends, "[c]omics-as a form that relies on space to represent time-becomes structurally equipped to challenge dominant modes of storytelling and history writing. ${ }^{\prime 3}$ The contestation of dominant historical narration

\footnotetext{
1 SuperQueeroes defines "queer comics" as "comics that include LGBTI characters and tell LGBTI stories." This definition elides "queer" and "LGBTI" and us es "queer" as an umbrella signifier for "LGBTI." This prefigures my forthcoming comments on the terminological and historical tension between specifically gay politics and queer as a politics, evident in the exhibition's section on mainstream comics. For the purposes of my review, I will continue to use the term "queer comics." See http://www.s chwules mus eum.de/en/exhibitions/view/s uperqueeroes-our-lgbti-comic-book-heroes-andheroines/

${ }^{2}$ While the geographic scope of SuperQueeroes is Europe and the U nited States, the exhibition includes a section on the important work of Gengoroh Tagame, a leading Japanese artist whose work features gay characters and homoerotic, and often violent, graphic narratives in the manga comics tradition.

${ }^{3}$ Hillary Chute, "Comics as Literature? Reading Graphic Narrative," PMLA 123, no. 2 (March 2008): 456.
} 
within the discursive and representational space of comics is most compellingly rehearsed in the exhibition's transposition of superheroes into the eponymous SuperQueeroes, positing the figures in comics as sites of heroic queer reimagining and the medium of comics as its privileged form.

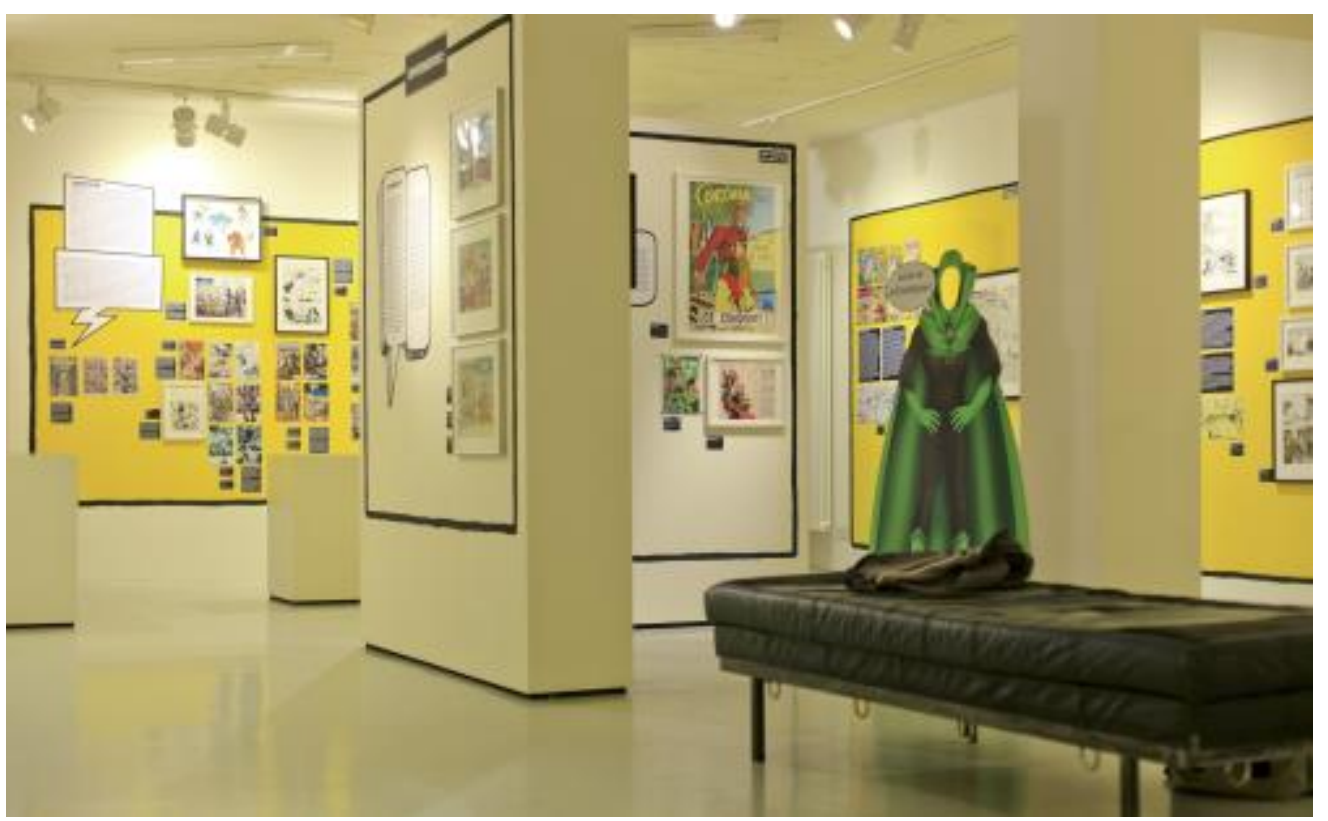

\section{Figure 1}

Installation view, entrance (from right), SuperQueeroes - Our LGBTI* Comic Book Heroes and Heroines, Schwules Museum*, Berlin, curated by Michael Bregel, Kevin Clarke, Natasha Gross, Hannes Hacke, Justin Hall, Markus Pfalzgraf, Mario Russo. P hotograph courtesy Robert M Berlin/Schwules* Museum.

In opening wall texts, the curators set the historical parameters of SuperQueeroes as the late 1960 s through the present, encapsulating a period beginning with the Stonewall Riots of 1969 through the consequent and varied formations of sexual politics in recent history. As the apotheosis of the gay liberation struggles of the 1960s, Stonewall symbolically ushered in a new era marked by the personalization of politics, specifically the public urgencies of gay and lesbian visibility, gender and sexual self-identification, and communal solidarity. Despite the American (US) focus of this narrative, the historical framework of the late 1960 s through the present productively structures SuperQueeroes without feeling reductive or prescriptive, since the exhibition is grouped around various themes-independent queer comics from the United States, independent queer comics from Europe, mainstream comics, everyday heroes, the comics author as hero, queer approaches to comics genres (cowboys, cops, adventurers), comics and AIDS, and the censorship of comics. ${ }^{4}$

\footnotetext{
${ }^{4}$ SuperQueeroes also includes a small section on Tom of Finland (Touko Laaksonen), whose pre- and post-Stonewall homoerotic drawings influenced the exhibition's post-Stonewall comics artists. For an important study on gay graphic arts before Stonewall, see Thomas Waugh, Out/Lines: Underground Gay Graphics From Before Stonewall (V ancouver: A rsenal Pulp Press, 2002).
} 
The post-Stonewall time frame is signified by the exhibition's displays of the proliferating queer comics culture in the United States, wherein the work of many nowrenowned independent practitioners beginning their careers in the 1970-80s-like Mary Wings, Alison Bechdel, Jennifer Camper, and Roberta Gregory-was streamlined and published under Howard Cruse's Gay Comix series (1980-1998). In contrast to this linear development in American queer comics history, the European comics presented provide an instructive counterpoint to the exhibition's chronology. Created under varying cultural and geopolitical circumstances, the work of the European artists featured, such as Ralf König (Germany), Nazario (Spain), Luca Enoch (Italy), Helena Janecic (Croatia), and Beata "Beatrix" Cymerman (Poland), evinces a multitude of queer experience against a singular historical narrative. Their works emerged autonomously and precariously in locally specific contexts, often with neither formal networks of queer exchange nor social landscapes of queer acceptance.

Both American and European independent queer comics challenge dominant histories by bearing witness to an astonishing plurality of queer experience - the curators' most captivating statement. From the quotidian to the spectacular, the asexual to the pornographic, the disabled to the fat to the dressed in drag, the exhibition testifies a politics rooted in a heterogeneity of sexual intersections and erotic encounters that queer comics artists actively reimagine in graphic narrative form. Rupert Kinnard's B.B. and the Diva (1979) depicts the first gay and lesbian-identified African-American protagonists in comics, while Justin Hall's Glamazonia (2010) portrays the adventures of the eponymous "Uncanny Super-Tranny." Gaye Mae Kincaid's Sapphowoman and the Greater Belfast Dykes (1980) references literary history by reinventing Sappho, the Ancient Greek homoerotic poet, as a lesbian superhero of Northern Ireland. A central section on the AIDS crisis further articulates the didacticism of independent comics as instruments of safe sex education and stigma fighting. ${ }^{5}$ These depictions of sexual plurality within the representational and social spaces of independent comics materialize many political worlds of queer life, pleasure, and activism, which SuperQueeroes convincingly advocates against cultural norms of invisibility and erasure.

A section on mainstream comics proves to be less successful (fig. 2). The introductory wall text argues that social progress is evincible through the increased visibility of nonnormative sexualities in mainstream comics. Various depictions of LGBTI characters and narratives in mainstream comics are presented, yet the central display of the $\mathrm{X}$-Men comic books featuring the superhero Northstar exemplifies the section's broader oversights. In 1992, Marvel expanded the scope of sexual representation in mainstream comics when writers determined that Northstar would come out as gay. Twenty years later following the legalization of same-sex marriage in New York, Marvel depicted "the first gay wedding" in comics when Northstar married his long-term partner Kyle. ${ }^{6}$ SuperQueeroes celebrates Northstar's narrative as a prime example of cultural acceptance and social change on behalf of Marvel comics and its audience.

\footnotetext{
${ }^{5}$ For more information on sex educationalcomics and censorship during the A I DS crisis, see Douglas Crimp, "How to Have Promiscuity in an Epidemic," in "A IDS: Cultural Analysis/Cultural A ctivism," ed. Douglas Crimp, special issue, October 43 (Winter 1987): 237-271.

${ }^{6}$ For details see Matthew Perpetua, "Marvel Comics Hosts First Gay Wedding in 'Astonishing X - Men'," Rolling Stone, May 22,2012, http://www.rollingstone.com/culture/news/marvel-comics-hosts-first-gaywedding-in-astonishing-x-men-20120522.
} 


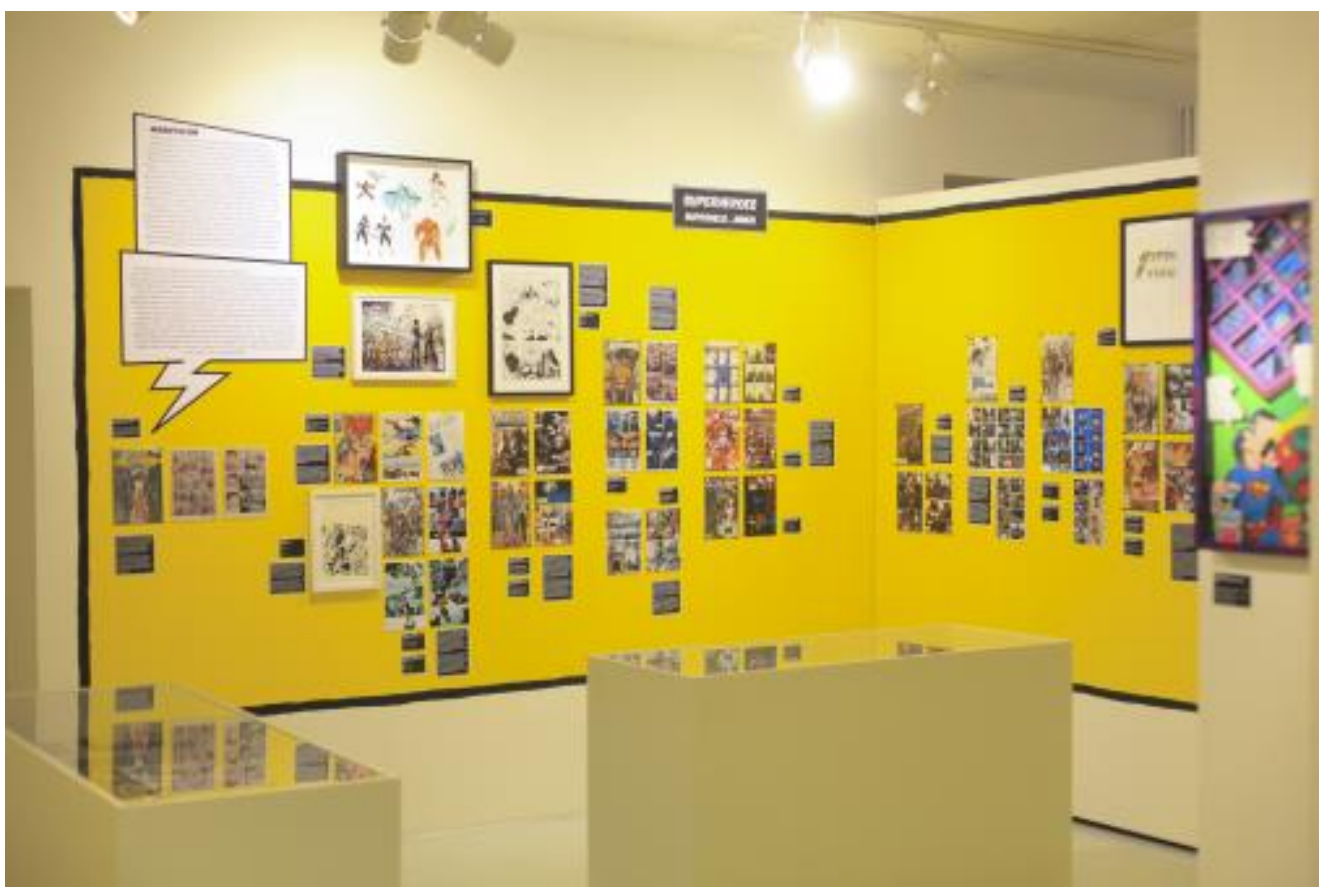

\section{Figure 2}

Installation view, "Mainstream" section, SuperQueeroes - Our LGBTI* Comic Book Heroes and Heroines, Schwules Museum*, Berlin, curated by Michael Bregel, Kevin Clarke, Natasha Gross, Hannes Hacke, Justin Hall, Markus Pfalzgraf, Mario Russo. P hotograph courtesy Robert M Berlin/Schwules* Museum.

Northstar's story, among others, reflects the departure of mainstream comics from their heteronormative industrial moorings, as well as productively expands the sphere of representations rendered legitimate, both within and beyond comics. Nevertheless, one must question whether narratives like Northstar's simply react to a dominant teleology of mainstream gay politics, rather than actively envisioning a politics rooted in the heterogeneity of queer experience. ${ }^{7}$ While the independent comics presented testify a diversity of desires through affective and imaginative representations derived from lived realities, the mainstream comics section compounds the pragmatic reduction of queer politics into gay visibility. ${ }^{8}$ This instance counterproductively risks advocating a "homonormative time line," where linear gay expectations either hegemonically singularize queer lives or further pathologize ones that fail to conform. ${ }^{9}$ Moreover, the challenges raised by the

\footnotetext{
${ }^{7}$ The exhibition does not consider the economic dimension of comic books as commodities, though the inclusion of LGBTI characters in mains tream comics nonetheless suggests the opening of the comics industry to new consumer demographics.

${ }^{8}$ For a compelling critique of the "gay pragmatis m" of the marriage agenda as well as an articulation of a utopian hermeneutics of queer representation, see José Esteban Muñoz, Cruising Utopia: The Then and There of Queer Futurity (New York: NYU Press, 2009), $19-32$.

9 See Nguyen Tan Hoang's response in Carolyn Dinshaw et al, "Theorizing Queer Temporalities: A Roundtable Discussion," GLQ: A Journal of Gay and Lesbian Studies 13, no. 2-3 (2007): 182-185.
} 
normatively "progressive" narratives of mainstream comics reflect the exhibition's broader elision of "queer comics" with "LGBTI stories," whereby queer is conflated with the individual (and unequally distributed) politics of sexuality and gender assumed under "LGBTI." Thus in contradistinction to a mainstream gay politics of acceptance and assimilation, which too often stands in for "LGBTI," "queer" antagonistically emerged as a sexual politics of world-building against normativity - both projects being necessary, historically contingent, and irreducible. Nonetheless what SuperQueeroes makes clear, and fails to question, is that mainstream comics follow from mainstream gay politics.

Beyond the productive questions of sexual representation that surface throughout SuperQueeroes, one technical limitation of the exhibition lies in the challenges of curating in accordance to the multifaceted medium-specificities of comics. Affixed to the gallery walls painted with black frames and yellow backgrounds to imitate a comic strip's graphic structure, most comic books were represented solely by their covers or were opened to a singular narrative moment, reducing longer stories to their most striking images (fig. 2). While comics are at once verbal and visual, they are fundamentally a tactile medium to be flipped through and read closely. Moreover, the affective and identificatory power of comics lie in their narrative temporality as well as in the intimate and embodied relation of comic book to the reader. By excluding the possibility of holding and reading the comics on display, SuperQueeroes unintentionally undermined both the narrative and tactile dimension of comics as a book form. Instead, the exhibition privileged optical experience, images over text, and a selective narrative interpretation, and further necessitated a strong reliance on explanatory wall texts for curatorial cohesion. This could have been easily rectified with a small sample of comics available to be actually read, underscoring their circulatory potential as a mechanically reproduced medium designed for reading, sharing, and the building of community and solidarity.

The final section on censorship deftly frames the rhetoric of heroization that runs throughout SuperQueeroes. On display is Frederic Wertham's 1954 study Seduction of the Innocent, where the German-American psychiatrist maintained that comics lead to juvenile delinquency and homosexuality. From his earlier writings through Seduction of the Innocent, Wertham's work both reflected and contributed to the postwar milieu of public paranoia and fear of external contamination. Its exposition and critique of the supposed negative effects of reading comics proffered a stricter revision of the Comics Code-the industry's standards implemented by comic book publishers-in addition to further establishing a norm of selfcensorship among comics artists. ${ }^{10}$ Through an archival mapping of documentary photographs and newspaper articles, SuperQueeroes visualizes the widespread institutionally organized burnings of comics throughout the United States and Europe following Wertham's publication and the tightening of the Comics Code. The censorship, sexual pathologization, and mass burning of comics that SuperQueeroes presents, as well as the exhibition's contextual interpolation into the cultural fabric of Berlin, draw an implicit and unsettling twofold parallel to specters of German history - the persecution of homosexuals in Nazi Germany and the nation-wide book burnings of 1933. While implicating an open and reflective relation to national history, SuperQueeroes reorients and compounds the courage of recreating queer life in comics - the medium that, as Hillary Chute argues, makes "visible the site of one's inscriptional effacement." 11 Against the inscriptional effacements of censorship, persecution

\footnotetext{
${ }^{10}$ For a detailed history of the Comics Book Code, see Amy Kiste Nyberg, Seal of Approval: The History of the Comics Code (Jackson: University of Mississippi Press, 1998).

${ }^{11}$ Hillary Chute, "The Texture of Retracing in Marjane Satrapi's 'Persepolis'," Women's Studies Quarterly 36, no. $1 / 2$ (Spring-Summer 2008): 106.
} 
histories, and heteronormative cultural narratives, SuperQueeroes illustrates the exhilarating plurality of queer comics and the durability of the lives that they heroically testify.

$(\mathrm{cc}) \overline{\mathrm{EY}}$ New articles in this journal are licensed under a Creative Commons Attribution 4.0 United States License.

\section{ULIS D-sorle}

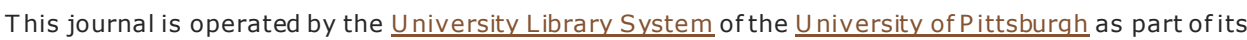

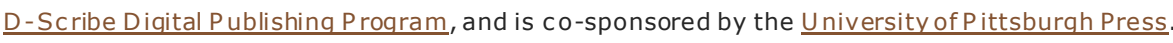



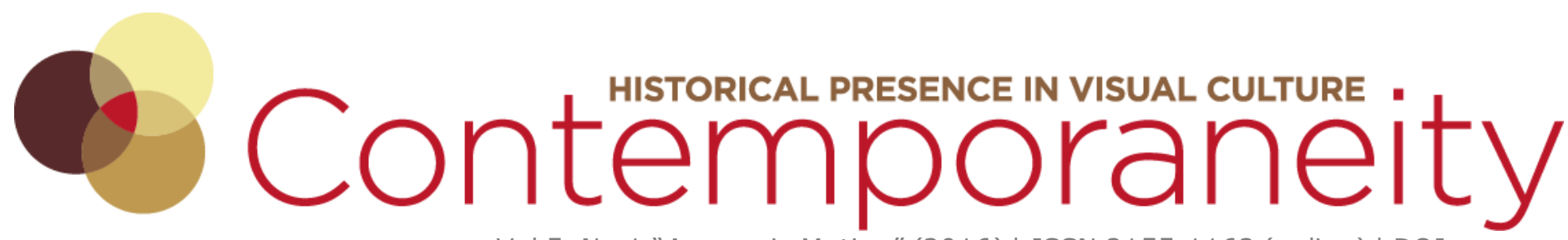

Vol 5, No 1 "Agency in Motion" (2016) | ISSN 2155-1162 (online) | DOI

\title{
David Lamelas's The Desert People: An Odyssey for Authentic Representation Hammer Museum, January 30-June 5, 2016
}

\section{Exhibition Review}

David Lamelas's The Desert People at UCLA's Hammer Museum, January 30-June 5, 2016.

\begin{abstract}
About the Author
Loretta Ramirez is a lecturer in the Chicano \& Latino Studies Department at California State University, Long Beach (CSULB). She is dedicated to the study of culture and cultural expression in its various written and visual forms. Loretta earned her BA in Anthropology from Stanford, her MA in English from Loyola Marymount, and a second M.A. in Art History at CSULB. She is currently pursuing her PhD in English with an emphasis on written and visual rhetoric at University of California, Irvine. When Loretta is not exploring the academic world, she enjoys promoting culture and art in her native Los Angeles at the J. Paul Getty Center where she volunteers as a Gallery Docent.
\end{abstract}




\section{David Lamelas's}

\section{The Desert People: An Odyssey} for Authentic Representation

\author{
Hammer Museum, \\ January 30 -June 5, 2016
}

Zooming in a brilliantly white Gran Torino sedan along an interstate, dissecting the surrounding desert, five travelers reflect on their five-week visit to the Native American reservation of the Papago people (Tohono O'odham) in southeastern Arizona (fig. 1). ${ }^{1}$ The testimonies of the travelers (an anthropologist, hippie, journalist, liberal, and Papago member) form the forty-four-minute narrative of David Lamelas's film, The Desert People (1974), screened at UCLA's Hammer Museum January 30-June 5, 2016.

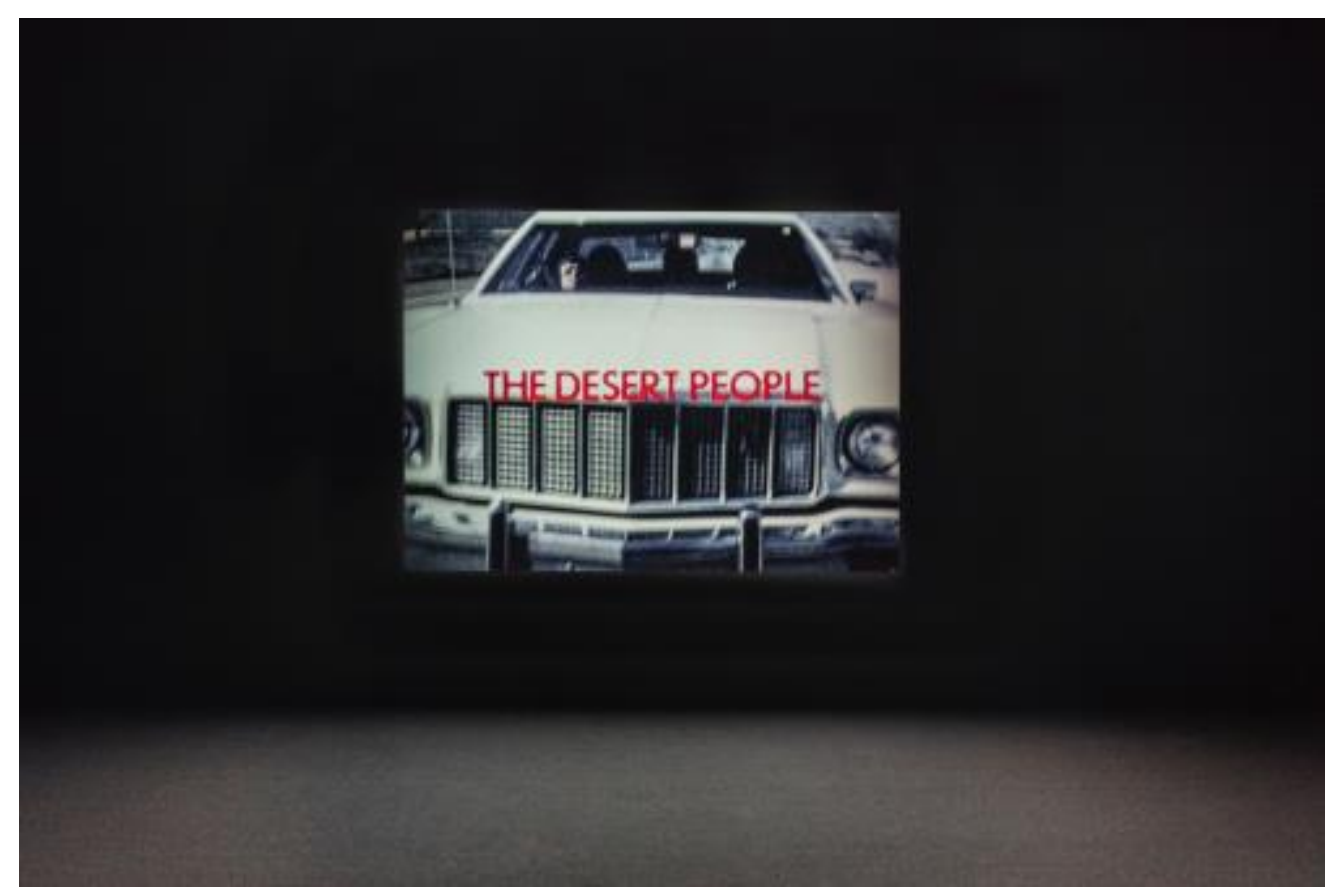

Figure 1

David Lamelas, The Des ert People, 1974. Still of title. $16 \mathrm{~mm}$ film transferred to DVD, color, sound, 44:09 min. Installation view. Hammer Museum, Los Angeles. Purchased through the Board of O verseers A cquisition Fund. Copyright David Lamelas, images courtesy of Maccaro ne, Sprüth Magers, and Jan Mot.

The accompanying soundtrack of funky beats and tangy electronics, shrieking tires, and roaring engines, paired with a camera that caresses the Gran Torino's glinting body as it

\footnotetext{
1 While the term "Papago" is no longer popularly used and the nation prefers the term Tohono O'odham, I will be referring to the O'odham represented in The Desert People as "the Papago." My choice of term is to remain consistent with the film's use of "Papago." For more information about the Tohono O'odham Nation and how the $\mathrm{O}$ 'odham self-identify, see: http://www.tonation-nsn.gov.
} 
speeds across scorching asphalt, imbue the film with seventies-era "road movie" ambia nce. However, Lamelas intercuts these features with documentary-style interview sequences, filmed uncomfortably up-close and from varying angles, making it impossible for the interviewees to escape the viewer's scrutiny. Shifting between flashy genre and seemingly candid study questions the veracity of the travelers' testimonies. The concept thus at play in the film is an examination of both distortions and accuracies of cultural representations, presented from an outsider perspective after an encounter of differences.

Screened at the Hammer in a black box room with six gray office chairs lined rigidly against the back wall, The Desert People was distanced from the single row of audience members by a long stretch of empty space. Hammer curator Aram Moshayedi and curatorial assistant MacKenzie Stevens designed this rather clinical observational setting to reinforce The Desert People's documentary aspect. This curatorial choice aligned with Lamelas's vision of the screening since Lamelas created his early films for museum settings. According to Maria José Herrera, Lamelas calls these films "movies made by a visual artist." 2 Thus, the Hammer underplayed the cinematic value of The Desert People while advancing its subject for critical analysis. This curatorial choice also limited the screening to six seated viewers, giving a sense of exclusivity rather than community. Accordingly, visitors might enter the exhibit with expectations to study the film as a documentary, which suggests that an interpretation of Papago life as it existed during the 1970s is still relevant. The curators stated in a wall text that Lamelas conceived the film in part as a fictional documentary, allowing audiences to wonder which parts are not fiction. This ambiguity is crucial to the viewing experience. I suggest that Lamelas, in fact, uses such ambiguity to focus analy sis not on the state of the Papago people so much as on the viewers' awareness of the impact of Western temporal and historical constructs on cultural representation.

In Lamelas's forty-year career, he has taken up a wide spectrum of mediums, from object-based to light and space, and from film to installation. In these diverse works Lamelas consistently constructs his pieces to partially de-stabilize and partially reinforce fragmented truths. This is seen in The Desert People, as well as Lamelas's earlier non-filmic works, including Office of Information about the Vietnam War at Three Levels (1968) in which Lamelas featured a room packed with state-of-the-art office equipment, displaying the glamorization of war while exploring the dissemination of news. The luxury modern furniture indicates privilege, safety, and comfort at the receiving end of devastating news of war, thereby questioning the effect of environment on interpretations of current events. Office of Information dismantles the concept that truth can be disseminated objectively through media; its filtering through time, distance, and perspective alters the reception and further propagation of news.

Similarly, The Desert People critiques dissemination of information via documentary film by offering eyewitness testimonies, the authenticity of which swiftly dissolves under the glamorization of a road movie narrative and the heightened awareness of the cultural distance between the road-trippers and the Papago (fig. 2). In this way, La melas analyzes the manner in which histories are constructed through detached testimony. Here, as in many of Lamelas's works, he suggests that viewers consider the accuracy of perceptions.

\footnotetext{
2 Maria José Herrera, "Introduction," in David Lamelas : Buenos Aires (Sáenz Peña: U niversidad N acional de Tres de Febrero, 2011), 23.
} 


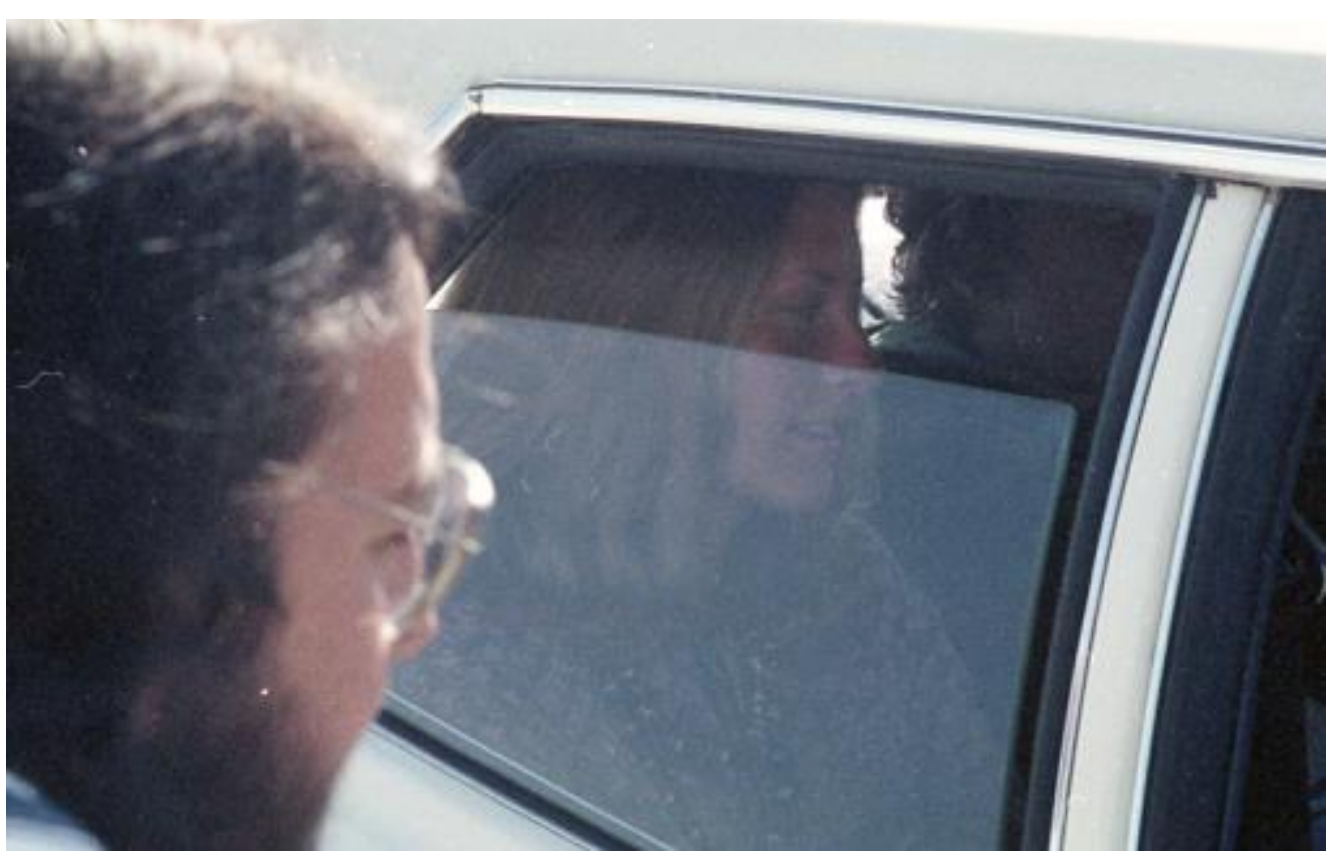

\section{Figure 2}

David Lamelas, The Desert People, 1974. Still of the travelers. $16 \mathrm{~mm}$ film transferred to DVD, color, sound, 44:09 min. Installation view. Hammer Museum, Los Angeles. Purchased through the Board of O verseers Acquisition Fund. Copyright David Lamelas, images courtesy of Maccarone, Sprüth Magers, and Jan Mot.

This investigation into perception is also present in Lamelas's earliest film works. In film, Lamelas immediately embraced the recording of time to demonstrate that time cannot, in fact, be captured. In Time as Activity (Düsseldorf) (1969), Lamelas filmed city life in three different locations in Düsseldorf from a fixed camera angle with no sound or narrative. Regarding this work, Lamelas has stated, "I was consciously working with time in this piece. The concept was the structure, or deconstruction, of time in Düsseldorf, where the film was made and shown." ${ }^{3}$ He designed the film's screening in Düsseldorf with the projector present in the room, functioning, according to Lamelas, "as a time projector, projecting another time than the real time." 4 Hence viewers witness the progress of time spreading across screen, as they consciously spend time, an awareness intensified by the sound and heat of a spinning projector. In this way, time fuses, implying that the past may never be fully regained because the present necessarily impedes our perception of the past. If time is not as simply linear as broadly conceived in Western tradition, might the structures of history be unsupportable? Further, this melding of past and present fosters consideration of time's relationship to our own reality and experiences, a consideration revisited five years later with The Desert People.

\footnotetext{
${ }^{3}$ A my Cappellazzo, "David Lamelas: Time as Activity (Düsseldorf), 1969," in Making Time: Considering Time as a Material in Contemporary Video and Film, ed. by A my Cappellazzo (Lake Worth: Palm Beach Institute of Contemporary Art, 2000), $62-63$.

${ }^{4}$ Ibid, 63.
} 
Here, Lamelas addresses elusive pasts through overlapping and partially fictionalized accounts, perhaps to provoke viewers to contemplate historical narratives and their impact on concepts of time and culture. In this way, Lamelas moves from an analysis of the broad construction of Western time in Time as Activity, to a consideration of time's relationship to culture and representation in The Desert People. At the same time, he moves from nonnarrative film to fictional documentary.

Assuming the role of preservationist, the first interviewee in The Desert People is a white male anthropologist who shares his studied observations of the Papago people (fig. 3). He believes that, beyond himself, the Papago have no champion to secure their history. Thus, the film begins with testimony from a non-indigenous person who claims guardianship of the Papago's history. However, as the film progresses with each new interview, interspersed amongst interludes of moving cars, the testimonies falter in their consistencies and intent since they speak more of themselves than of the Papago.

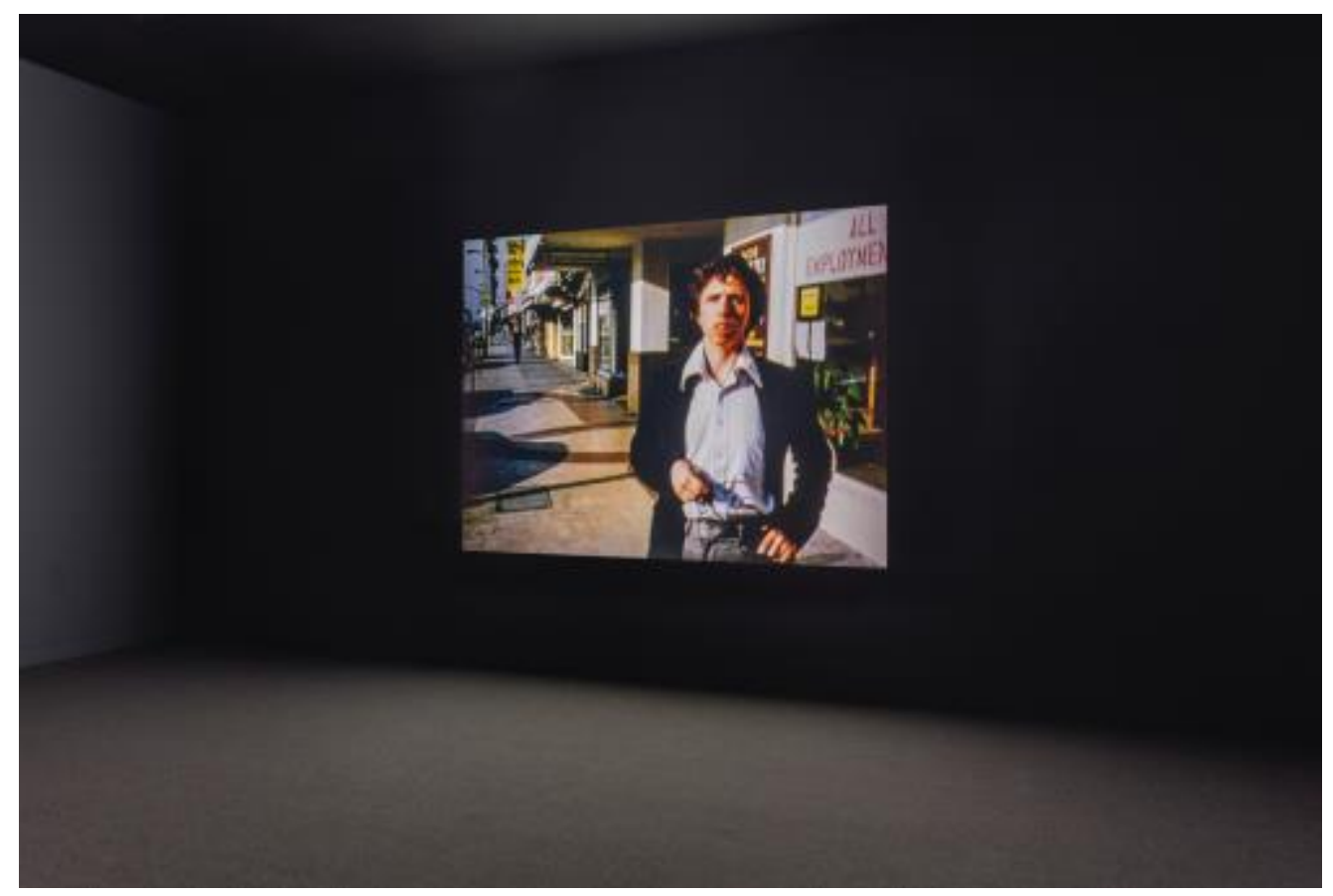

\section{Figure 3}

David Lamelas, The Desert People, 1974. Still of the anthropologist's tes timony. $16 \mathrm{~mm}$ film transferred to DV D, color, sound, 44:09 min. Installation view. Hammer M useum, Los Angeles. P urchased through the Board of O verseers Acquisition Fund. Copyright David Lamelas, images courtesy of Maccarone, Sprüth Magers, and Jan Mot.

For example, the white female New York journalist is keen to discuss the reservation women whose community contributions humble the journalist, newly a ware of her lesser impact on her own society. Meanwhile, the white male Californian liberal laments this same tightknit indigenous community, deeming it divisive against outsiders, thus thwarting his hopes to romance Papago females. Contrasting with these perspectives is the last interviewee, a Papago man named Manny, who perceives indigenous life as unraveling due to loss of language, tradition, and unity-himself displaced and living off-reservation (fig. 4). For Manny, this is a desperate time, as he attests that "much of our culture has died and is dying now." 


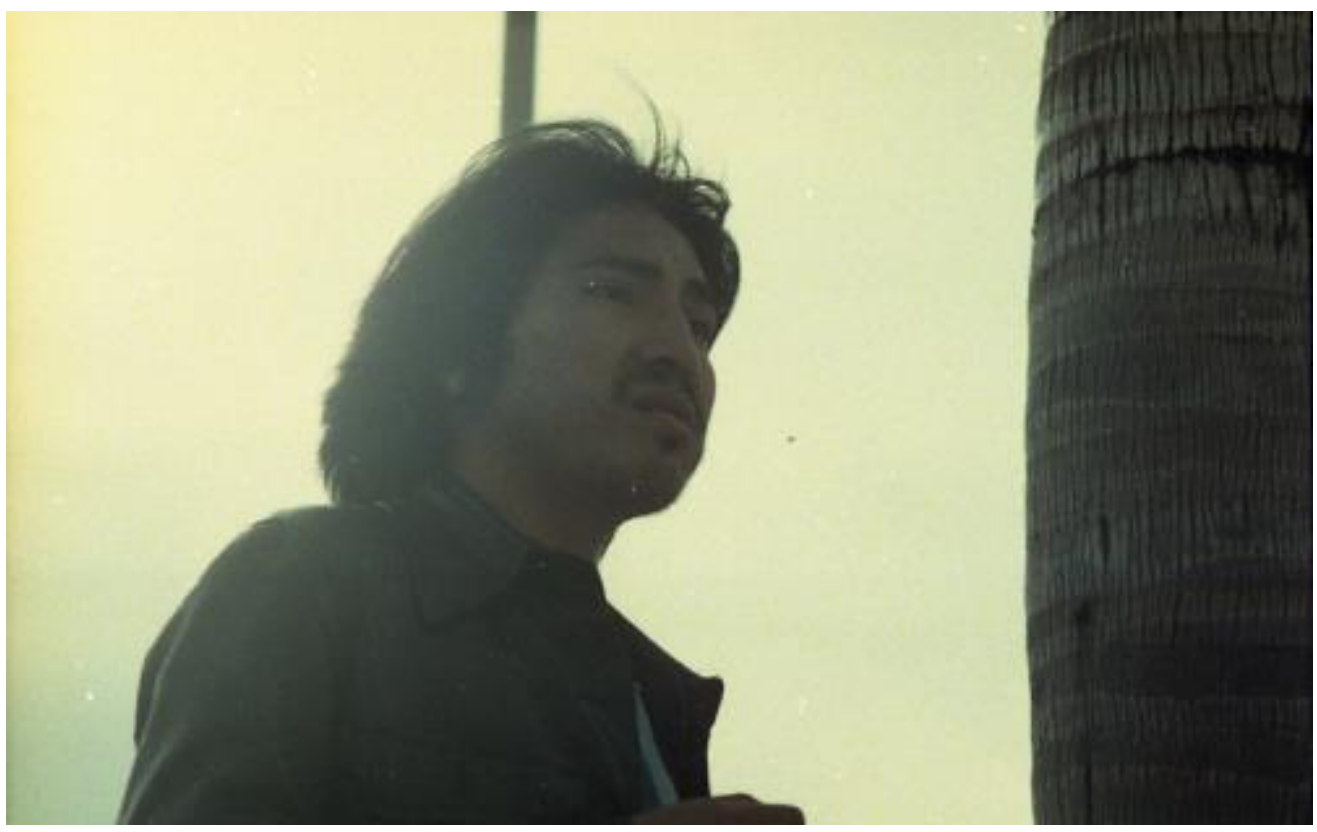

\section{Figure 4}

David Lamelas, The Desert People, 1974. Still of Manny's monologue. $16 \mathrm{~mm}$ film transferred to DV D, color, sound, 44:09 min. Installation view. Hammer Museum, Los Angeles. Purchased through the Board of O vers eers Acquisition Fund. Copyright David Lamelas, images courtesy of Maccarone, Sprüth Magers, and Jan Mot.

While saved for last as the Papago's "true" voice, Manny ironically loses authenticity. His testimony is undermined by the film's heightened dramatics, staged against the desert landscape and brimming with his poetic musings. This contrasts with the three other travelers' faster-paced testimonies that express less organized ideas, filmed seemingly spontaneously inside a diner or along a busy street. Manny is also the only subject to turn his back on the camera in a choreographed melancholic walk toward an empty horizon, rather than the frontal positioning to which the camera exposed the others. Finally, with theatrical purpose his speaking is methodically precise, delivered from a carefully crafted script. Hence, for audiences, the seemingly most authoritative voice is surprisingly the least convincing, albeit the most poignant.

However, Manny does not seem concerned with convincing anyone of truths. He is not attempting to inform; rather, his implied purpose is to raise awareness and maintain cultural survival. To achieve this, he considers the methods of his fellow travelers whose efforts he credits: "I suppose it is up to the people themselves to keep the culture-to pull it up. And the only way to pull it up is to listen to and talk to the old people that are left, the ones that really have some storage of what it was like. That's what these people have done. And I feel it is up to those people, who want to preserve it, to do it." In Manny's monologue, "truth" is secondary to "representation." Reality is less important than maintaining a story, even a fragmented and partially fictionalized one.

Manny continues, "[t]his is one way of doing it, I think - performing. Perhaps I'm wrong, but my heart is in performing and that is where it's going to stay." In this moment, any illusion that The Desert People is a documentary film dissipates. Manny is a professional actor performing a story that might be related to his heritage-but even that is in question. Is he really of the Papago people? 


\section{Does it matter?}

If Manny's goal is to keep alive through performance that which he, as a character in the film, views as a dying culture, then his authenticity as a Papago person is not relevant. After all, viewers may now be wondering what, exactly, is the state of the Papago. Is the culture dying, as suggested by Manny, the scripted voice of the Papago? Or, is the portrayal of the culture obscured by Manny's possible outsider assumptions? Viewers may also notice that, besides the character of Manny, the film includes no Papago people and no footage of the reservation. The film is thus not necessarily about the Papago, and it does not advance "vanishing race" rhetoric. Rather, Manny's monologue about his dying culture invites criticism of such rhetoric by exposing a flawed and fictional narrative of cultural representation.

Accordingly, I propose that the film's purpose is to undermine the documentary format's authority to capture a specific reality. Concurrently, the film stimulates the viewer's curiosity and agency to more acutely process their observations, thus freeing them from traditional structures of historical and cultural narratives. Such observations may spark future explorations into the Papago or similarly underrepresented communities whose portrayals within Western culture are also too faulty to believe, yet nonetheless inspire attempts of recovery.

It is therefore fitting that Lamelas borrows the road movie genre in its countercultural celebration of unbound, open-road freedom, exemplified in the films Zabriskie Point (1970) by Michelangelo Antonioni, and Two-Lane Blacktop (1971) by Monte Hellman. The Desert People was Lamelas's first professionally produced film in Los Angeles, and marks a union between his art and the culture industry. ${ }^{5}$ On the wall label of the exhibit, the Hammer quotes Lamelas, who defines this work as "a study on American film production"; thereby Lamelas packages his art within a glossy road movie genre that embraces codes of mass culture, an attempt to use popular format to bridge concept with audience. By appropriating the aesthetic of this genre, Lamelas underscores the theme of propulsion into new territories and new ways of living and thinking, mental explorations that are consistent with his four decades of work in which audience agency inhibits stagnancy and fosters mindfulness of the present.

Lamelas has expressed hope that his artworks live on, that they "leave me behind. It's not about me. It's about itself . . . It's not my piece. It's itself. It evolves in time. ${ }^{16}$ Art has a life of its own, driven forward by audience interaction. If in The Desert People culture becomes partially fictionalized, then culture as a broad concept becomes artistic performance. In Lamelas's vision, this is not an entirely negative fate, but rather a fragmented alternative to authoritative histories. Truth is incomplete; authenticity is suspect, but perhaps a thread of the past survives when visual culture cultivates human relations and agency to explore. This, I believe, is the message of The Desert People.

\footnotetext{
5 Benjamin H. D. Buchloh, "Structure, Sign, and Reference in the Work of David Lamelas," in David Lamelas: extranjero, foreigner, étranger, Ausländer (Mexico, DF : Fundacion Olga y Rufino Tamayo, 2006), $139-142$.

6 David Lamelas, interview by Catha Paquette, Long Beach, March 1 0, 2016 , recording by Yukiko Hole. This interview was arranged, in part, as a preparation for the September 2017 to January 2018 exhibition of Lamelas's art at the California State University, Long Beach U niversity A rt Museum, sponsored by the J. Paul Getty Pacific Standard Time: LA/LA initiative.
} 
(cc) BY

New articles in this journal are licensed under a Creative Commons Attribution 4.0 United States License.

\section{UILIS D-Surle}

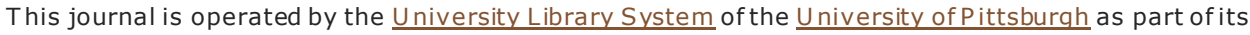
D-Scribe Digital Publishing Program, and is co-sponsored by the University of Pittsburgh Press. 